Nevada

Environmental

Restoration

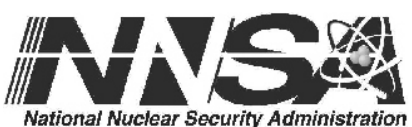

Project

Closure Report for Corrective

Action Unit 127: Areas 25 and 26 Storage Tanks, Nevada Test Site,

Nevada

Controlled Copy No::

Revision: 0

February 2008

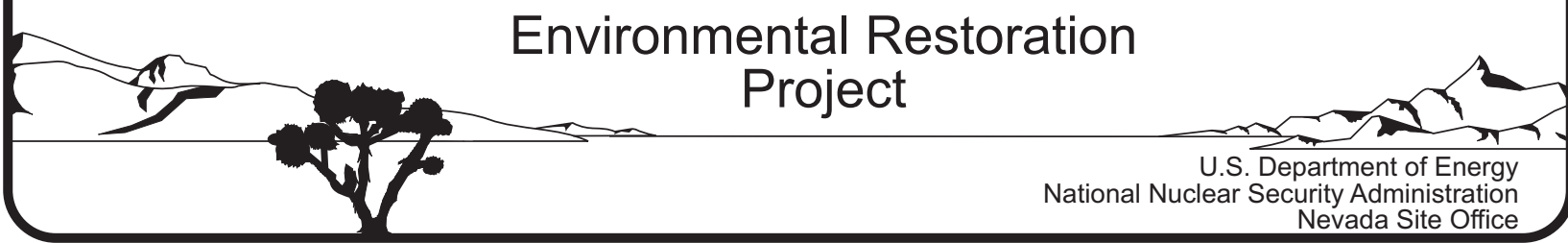




\title{
DISCLAIMER
}

Reference herein to any specific commercial product, process, or service by trade name, trademark, manufacturer, or otherwise, does not necessarily constitute or imply its endorsement, recommendation, or favoring by the United States Government or any agency thereof or its contractors or subcontractors.

This report has been reproduced directly from the best available copy.

Available for sale to the public from:

\author{
U.S. Department of Commerce \\ National Technical Information Service \\ 5285 Port Royal Road \\ Springfield, VA 22161-0002 \\ Telephone: (800) 553-6847 \\ Fax: (703) 605-6900 \\ E-mail: orders@ntis.gov \\ Online ordering: http://www.ntis.gov/ordering.htm
}

Available electronically at http://www.osti.gov/bridge.

Available for a processing fee to the U.S. Department of Energy and its contractors, in paper, from:

U.S. Department of Energy

Office of Scientific and Technical Information

P.O. Box 62

Oak Ridge, TN 37831-0062

Telephone: (865) 576-8401

Fax: (865) 576-5728

E-mail: reports@adonis.osti.gov 


\title{
CLOSURE REPORT FOR CORRECTIVE ACTION UNIT 127: AREAS 25 AND 26 STORAGE TANKS, NEVADA TEST SITE, NEVADA
}

\author{
U.S. Department of Energy \\ National Nuclear Security Administration \\ Nevada Site Office \\ Las Vegas, Nevada
}

Controlled Copy No.

Revision: 0

February 2008 
THIS PAGE INTENTIONALLY LEFT BLANK 


\section{CLOSURE REPORT FOR CORRECTIVE ACTION UNIT 127: AREAS 25 AND 26 STORAGE TANKS, NEVADA TEST SITE, NEVADA}

Approved By: $\frac{\text { Original signed by: K Cabble }}{\text { Kevin J. Cabble }} \begin{aligned} & \text { Federal Sub-Project Director } \\ & \text { Industrial Sites Sub-Project }\end{aligned}$ Date:

Approved By: $\frac{\text { Original signed by: J Jones }}{\text { John B. Jones }}$ Date: $2 / 3 / 48$
Acung Federal Project Director
Envirommental Restoration Project 
THIS PAGE INTENTIONALLY LEFT BLANK 


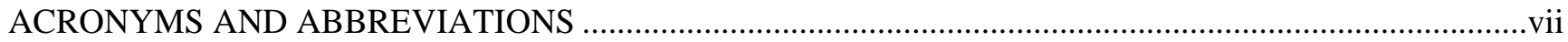

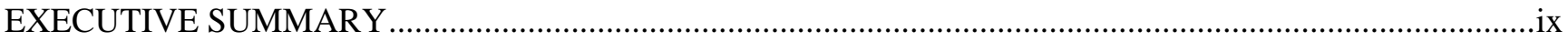

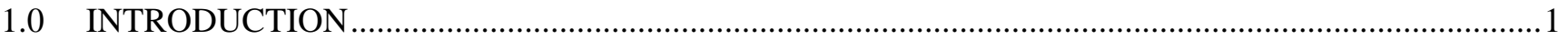

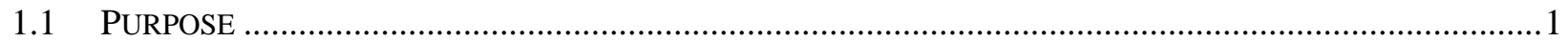

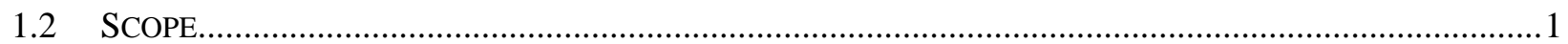

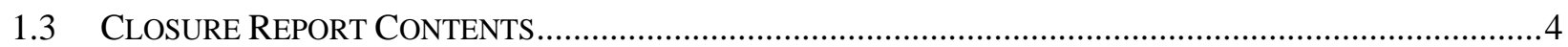

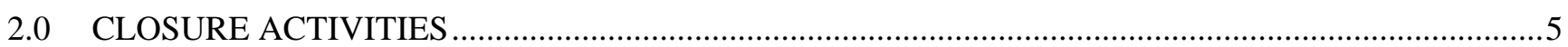

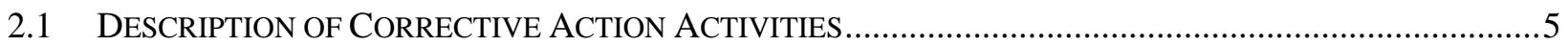

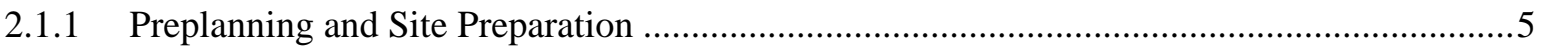

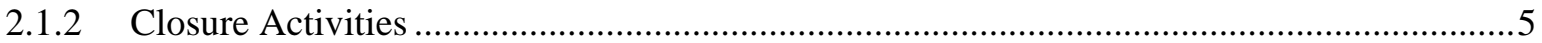

2.1.2.1 Corrective Action Site 25-01-05, Aboveground Storage Tank .............................. 5

2.1.2.2 Corrective Action Site 25-01-06, Aboveground Storage Tank .............................. 7

2.1.2.3 Corrective Action Site 25-01-07, Aboveground Storage Tank .............................. 7

2.1.2.4 Corrective Action Site 25-02-02, Underground Storage Tank..............................10

2.1.2.5 Corrective Action Site 25-02-13, Underground Storage Tank.............................. 10

2.1.2.6 Corrective Action Site 25-12-01, Boiler ..............................................................11

2.1.2.7 Corrective Action Site 25-23-11, Contaminated Materials .....................................11

2.1.2.8 Corrective Action Site 26-01-01, Filter Tank (RAD) and Piping ........................14

2.1.2.9 Corrective Action Site 26-01-02, Filter Tank (RAD) .........................................14

2.1.2.10 Corrective Action Site 26-02-01, Underground Storage Tank.............................14

2.1.2.11 Corrective Action Site 26-23-01, Contaminated Liquids Spreader........................14

2.1.2.12 Corrective Action Site 26-99-01, Radioactively Contaminated Filters.................17

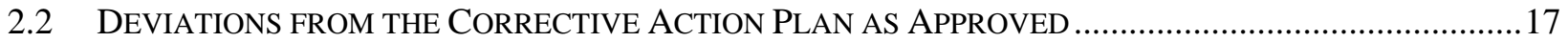

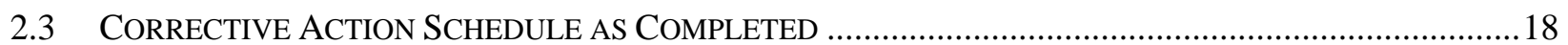

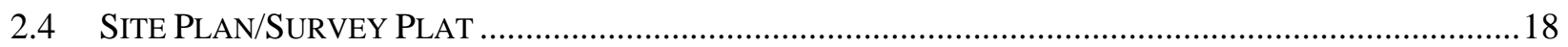

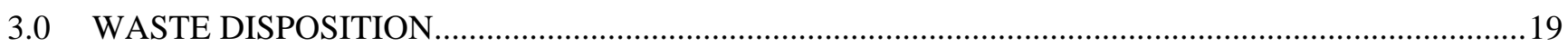

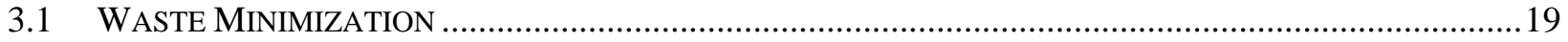

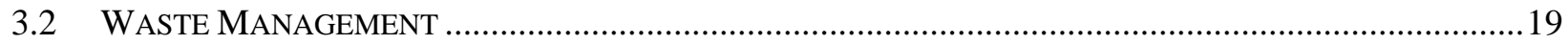

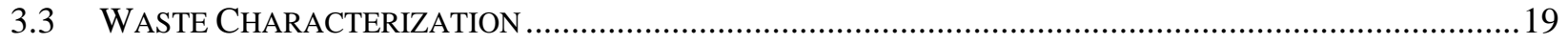

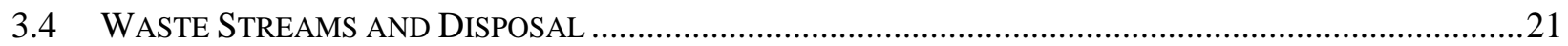

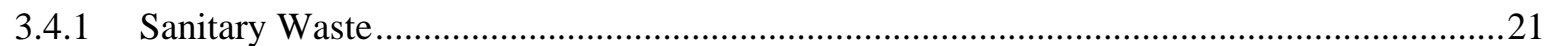

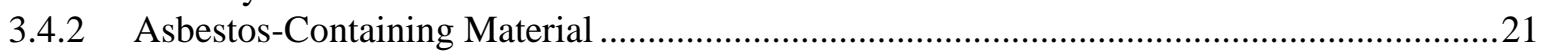

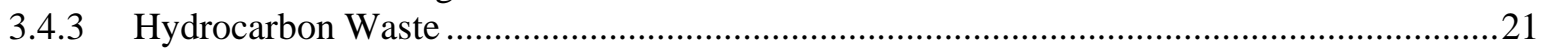

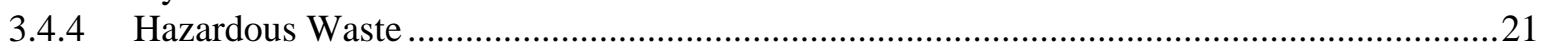

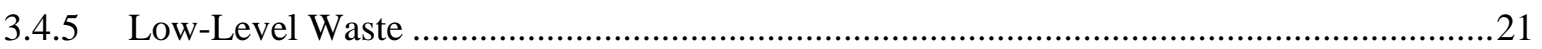

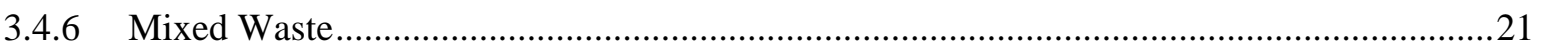

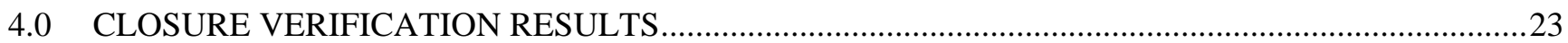

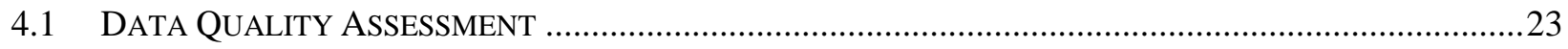

4.1.1 Quality Assurance/Quality Control Procedures...........................................................23

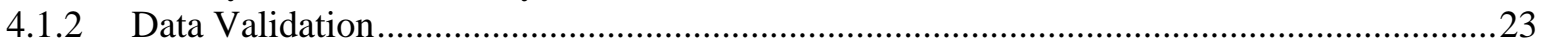

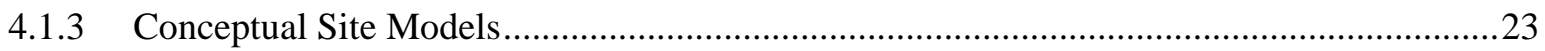

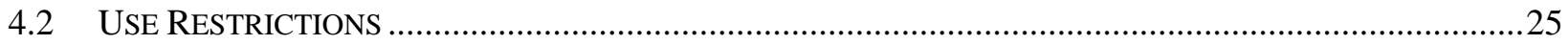

4.2.1 Corrective Action Site 25-01-07, Aboveground Storage Tank .........................................25

4.2.2 Corrective Action Site 25-02-02, Underground Storage Tank .........................................25 


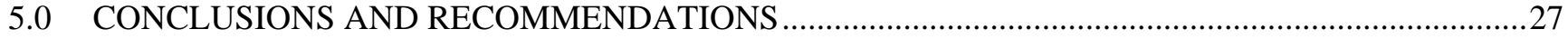

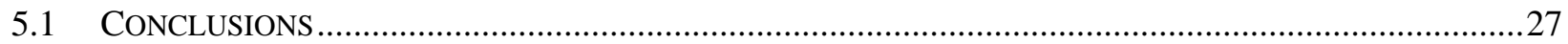

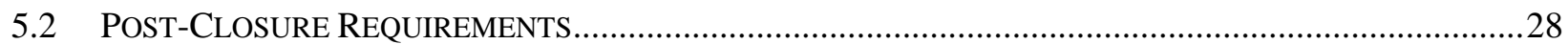

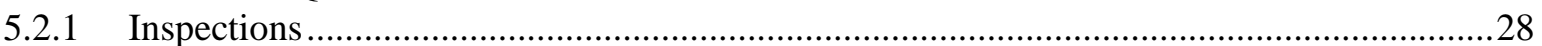

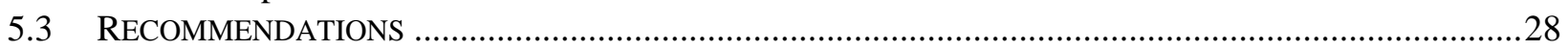

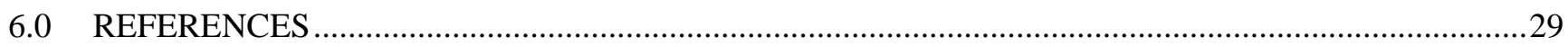

LIBRARY DISTRIBUTION LIST

\section{LIST OF FIGURES}

Figure 1. Corrective Action Unit 127 Site Location Map .......................................................2

Figure 2. CORrective Action Site 25-01-05, Aboveground Storage TANK, And Corrective ACTION SiTE 25-02-02, UnDERGROUND STORAGE TANK.................................................6

Figure 3. Corrective Action Site 25-01-06, Aboveground Storage TANK ................................8

Figure 4. Corrective Action Site 25-01-07, Aboveground StORAge TANK ...............................9

Figure 5. Corrective Action Site 25-12-01, Boiler ................................................................. 12

Figure 6. Corrective Action Site 25-23-11, Contaminated Materials....................................13

Figure 7. Corrective Action Site 26-01-01, Filter TANK (RAD) AND Piping; Corrective Action SiTE 26-01-02, FILTER TANK (RAD); AND CORRECTIVE ACTION SiTE 26-99-01,

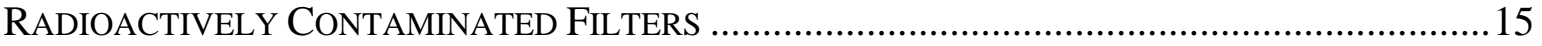

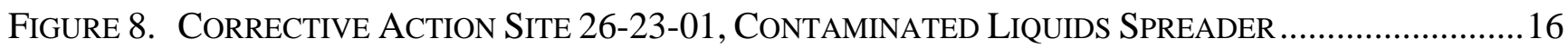

\section{LIST OF TABLES}

Table 1. Summary of Corrective Action Unit 127 Closure Activities.................................... X

Table 2. Corrective Action Unit 127 Closure Activities Schedule .....................................18

Table 3. Corrective Action Unit 127 WAste Disposition SUMmary ........................................20

TABle 4. Corrective ACtion Site 25-01-06, AbOVEground StORAGE TANK, VERIFICATION

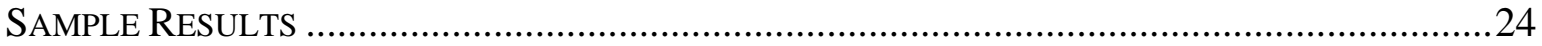

TABle 5. Corrective ACtion Site 25-23-13, Contaminated MATERials, Verification SAMPLE RESULTS

Table 6. Corrective Action Site 26-01-01, Filter Tank (RAD) AND Piping, Verification SAMPLE RESULTS

\section{APPENDICES}

APPEndiX A. DATA QuALiTy OBJECTIVES

APPENDIX B. SAMPLE ANALYTICAL RESUltS

APPENDIX C. WASTE DISPOSITION DOCUMENTATION

APPENDIX D. USE RESTRICTION DOCUMENTATION

APPENDIX E. Site ClOSURE PHOTOGRAPHS 


\begin{tabular}{|c|c|}
\hline $\mathrm{ACM}$ & asbestos-containing material \\
\hline AST & aboveground storage tank \\
\hline BMP & best management practice \\
\hline CAP & Corrective Action Plan \\
\hline CAS & Corrective Action Site \\
\hline CAU & Corrective Action Unit \\
\hline COC & contaminant of concern \\
\hline CR & Closure Report \\
\hline CSM & conceptual site model \\
\hline DRO & diesel range organics \\
\hline E-MAD & Engine Maintenance, Assembly, and Disassembly \\
\hline EPA & U.S. Environmental Protection Agency \\
\hline ETSM & Engine Transport System Maintenance \\
\hline FFACO & Federal Facility Agreement and Consent Order \\
\hline $\mathrm{ft}$ & foot (feet) \\
\hline gal & gallon(s) \\
\hline GRO & gasoline range organics \\
\hline HW & hazardous waste \\
\hline LLW & low-level waste \\
\hline $\mathrm{mg} / \mathrm{kg}$ & milligram(s) per kilogram \\
\hline MW & mixed waste \\
\hline ND & not detected \\
\hline NDEP & Nevada Division of Environmental Protection \\
\hline NNSA/NSO & $\begin{array}{l}\text { U.S. Department of Energy, National Nuclear Security Administration Nevada } \\
\text { Site Office }\end{array}$ \\
\hline NNSA/NV & $\begin{array}{l}\text { U.S. Department of Energy, National Nuclear Security Administration Nevada } \\
\text { Operations Office }\end{array}$ \\
\hline NTS & Nevada Test Site \\
\hline $\mathrm{pCi} / \mathrm{g}$ & picocuries(s) per gram \\
\hline PCB & polychlorinated biphenyl \\
\hline QA & quality assurance \\
\hline
\end{tabular}




\section{ACRONYMS AND ABBREVIATIONS (continued)}

QAPP Quality Assurance Project Plan

QC quality control

RMA Radioactive Materials Area

RWMS Radioactive Waste Management Site

TCC Test Cell C

TPH total petroleum hydrocarbons

UR use restriction

UST underground storage tank

WMA waste management area

$\mathrm{yd}^{3} \quad$ cubic yard(s) 
Corrective Action Unit (CAU) 127 is identified in the Federal Facility Agreement and Consent Order (FFACO) as Areas 25 and 26 Storage Tanks. CAU 127 is located in Areas 25 and 26 of the Nevada Test Site, approximately 65 miles northwest of Las Vegas, Nevada, and consists of the following twelve Corrective Action Sites (CASs):

- CAS 25-01-05, Aboveground Storage Tank

- CAS 25-01-06, Aboveground Storage Tank

- CAS 25-01-07, Aboveground Storage Tank

- CAS 25-02-02, Underground Storage Tank

- CAS 25-02-13, Underground Storage Tank

- CAS 25-12-01, Boiler

- CAS 25-23-11, Contaminated Materials

- CAS 26-01-01, Filter Tank (RAD) and Piping

- CAS 26-01-02, Filter Tank (RAD)

- CAS 26-02-01, Underground Storage Tank

- CAS 26-23-01, Contaminated Liquids Spreader

- CAS 26-99-01, Radioactively Contaminated Filters

CAU 127 closure activities were conducted from January 2007 to January 2008 according to the FFACO (FFACO, 1996; as amended January 2007) and the Corrective Action Plan for CAU 127 (U.S. Department of Energy, National Nuclear Security Administration Nevada Site Office, 2004b). The corrective action alternatives included no further action, clean closure, and closure in place with administrative controls. CAU 127 closure activities are summarized in Table 1.

Closure activities generated the following waste streams: sanitary waste, asbestos-containing material waste, hydrocarbon waste, low-level waste, hazardous waste, and mixed waste. Waste generated was appropriately managed and disposed. Waste that is currently staged onsite is being appropriately managed and will be disposed under approved waste profiles in permitted landfills. Waste minimization activities included segregation of waste streams, field screening, and size reduction. Some wastes exceeded land disposal restriction limits and required offsite treatment prior to disposal. Other wastes meeting land disposal restrictions were disposed of in appropriate onsite or offsite landfills. Waste disposition documentation is included as Appendix C. 
Date: February 2008

TAble 1. Summary OF CoRrective ACTION Unit 127 Closure Activities

\begin{tabular}{|c|c|c|c|c|}
\hline CAS & CAS Name & Closure Method & $\mathrm{COC}$ & Closure Activities \\
\hline 25-01-05 & Aboveground Storage Tank & Clean Closure & Radiological & $\begin{array}{ll}\text { - } & \text { Removed AST and associated aboveground piping for disposal as LLW } \\
\text { - } & \text { Removed cadmium- and asbestos-insulated piping for offsite disposal as MW } \\
\text { - } & \text { Grouted remaining underground piping }\end{array}$ \\
\hline 25-01-06 & Aboveground Storage Tank & Clean Closure & ТPH & $\begin{array}{l}\text { - } \quad \text { Removed and solidified TPH-impacted liquid from AST for disposal as hydrocarbon waste } \\
\text { - } \quad \text { Removed AST, associated piping, and concrete pad for disposal as sanitary waste } \\
\text { - } \quad \text { Excavated TPH-impacted soil for disposal as hydrocarbon waste } \\
\text {. }\end{array}$ \\
\hline $25-01-07$ & Aboveground Storage Tank & $\begin{array}{l}\text { Closure in Place } \\
\text { with } \\
\text { Administrative } \\
\text { Controls }\end{array}$ & ТPH & $\begin{array}{ll}\text { - } & \text { Removed and solidified TPH-impacted liquid from AST for disposal as hydrocarbon waste } \\
\text { - } & \text { Removed AST, associated piping, and concrete pad for disposal as sanitary waste } \\
\text { - } & \text { Excavated TPH-impacted soil to approximately } 5 \text { feet for disposal as hydrocarbon waste } \\
\text { - } & \text { Backfilled excavation } \\
\end{array}$ \\
\hline $25-02-02$ & Underground Storage Tank & $\begin{array}{l}\text { Closure in Place } \\
\text { with } \\
\text { Administrative } \\
\text { Controls }\end{array}$ & Radiological & $\begin{array}{ll}\text { - } & \text { Excavated overburden } \\
\text { - } & \text { Removed radiologically contaminated soil and concrete pad for disposal as LLW } \\
\text { - } & \text { Removed piping for offsite disposal as MW } \\
\text { - } & \text { Solidified UST contents and filled USTs with grout } \\
\text { - } & \text { Backfilled excavation } \\
\end{array}$ \\
\hline $25-02-13$ & Underground Storage Tank & No Further Action & None & - $\quad$ None \\
\hline $25-12-01$ & Boiler & Clean Closure & Asbestos & $\begin{array}{l}\text { - } \quad \text { Removed cadmium-insulated piping for offsite disposal as HW } \\
\text { - } \quad \text { Removed boiler for disposal as ACM } \\
\text { CAU 116, as documented in a Record of Technical Change to the Streamlined Approach for } \\
\text { Environmental Restoration Plan for CAU } 116\end{array}$ \\
\hline $25-23-11$ & Contaminated Materials & Clean Closure & Radiological & $\begin{array}{l}\text { - } \quad \text { Removed lead bricks, radiologically and lead-impacted soil from vault, concrete pump vault, pump, } \\
\text { and piping for offsite disposal as MW } \\
\text { - } \quad \text { Removed metal shed and radiologically contaminated soil for disposal as LLW } \\
\text { - } \quad \text { Collected verification samples and backfilled excavation }\end{array}$ \\
\hline 26-01-01 & Filter Tank (RAD) and Piping & Clean Closure & $\begin{array}{l}\text { Radiological, } \\
\text { Lead }\end{array}$ & $\begin{array}{ll}\text { - } & \text { Removed AST for disposal as LLW } \\
\text { - } & \text { Removed associated piping and radiologically and lead-impacted soil for offsite disposal as MW } \\
\text { - } & \text { Collected verification samples and backfilled excavation }\end{array}$ \\
\hline 26-01-02 & Filter Tank (RAD) & Clean Closure & Radiological & - $\quad$ Removed AST and associated piping for disposal as LLW \\
\hline 26-02-01 & Underground Storage Tank & No Further Action & None & - $\quad$ As a BMP, filled UST with grout \\
\hline
\end{tabular}


TABle 1. Summary of CAU 168 Closure Activities (CONTINUEd)

\begin{tabular}{|c|c|c|c|c|}
\hline CAS & CAS Name & Closure Method & COC & Closure Activities \\
\hline 26-23-01 & $\begin{array}{l}\text { Contaminated Liquids } \\
\text { Spreader }\end{array}$ & Clean Closure & Radiological & $\begin{array}{ll}\text { - } & \text { Removed lead shield for offsite disposal as MW } \\
\text { - } & \text { Removed spreader and radiologically contaminated soil for disposal as LLW }\end{array}$ \\
\hline 26-99-01 & $\begin{array}{l}\text { Radioactively Contaminated } \\
\text { Filters }\end{array}$ & Clean Closure & Radiological & $\begin{array}{l}\text { - } \quad \text { Removed filter tanks, associated piping, and wooden shed for disposal as LLW } \\
\text { - } \quad \text { Removed a PCB ballast for offsite disposal as PCB waste, a lead brick for offsite disposal as MW, a } \\
\text { fluorescent light bulb for offsite disposal as universal waste, and a hydraulic jack for disposal as LLW }\end{array}$ \\
\hline
\end{tabular}

ACM: asbestos-containing material

AST: aboveground storage tank

BMP: best management practice

CAS: Corrective Action Site

CAU: Corrective Action Unit

COC: contaminant of concern

HW: hazardous waste

LLW: low-level waste

MW: mixed waste

PCB: polychlorinated biphenyl

TPH: total petroleum hydrocarbons

UR: use restriction

UST: underground storage tank 
CAU 127 Closure Report

Section: Executive Summary

Revision: 0

Date: February 2008

THIS PAGE INTENTIONALLY LEFT BLANK 
This Closure Report (CR) documents closure activities for Corrective Action Unit (CAU) 127, Areas 25 and 26 Storage Tanks, according to the Federal Facility Agreement and Consent Order (FFACO) (FFACO, 1996; as amended January 2007) and the Corrective Action Plan (CAP) for CAU 127 (U.S. Department of Energy, National Nuclear Security Administration Nevada Site Office [NNSA/NSO], 2004b). CAU 127 is located in Areas 25 and 26 of the Nevada Test Site (NTS) (Figure 1) and consists of the following twelve Corrective Action Sites (CASs):

- CAS 25-01-05, Aboveground Storage Tank

- CAS 25-01-06, Aboveground Storage Tank

- CAS 25-01-07, Aboveground Storage Tank

- CAS 25-02-02, Underground Storage Tank

- CAS 25-02-13, Underground Storage Tank

- CAS 25-12-01, Boiler

- CAS 25-23-11, Contaminated Materials

- CAS 26-01-01, Filter Tank (RAD) and Piping

- CAS 26-01-02, Filter Tank (RAD)

- CAS 26-02-01, Underground Storage Tank

- CAS 26-23-01, Contaminated Liquids Spreader

- CAS 26-99-01, Radioactively Contaminated Filters

\subsection{Purpose}

CAU 127, Areas 25 and 26 Storage Tanks, consists of twelve CASs located in Areas 25 and 26 of the NTS. The closure alternatives included no further action, clean closure, and closure in place with administrative controls. The purpose of this CR is to provide a summary of the completed closure activities, documentation of waste disposal, and analytical data to confirm that the remediation goals were met.

\subsection{SCOPE}

The closure strategy for CAU 127 was as follows:

- CAS 25-01-05, Aboveground Storage Tank, was clean closed by removing a 100,000-gallon (gal) aboveground storage tank (AST) and associated aboveground piping for disposal as low-level waste (LLW). Cadmium- and asbestos-insulated piping was removed for offsite disposal as mixed waste (MW). 


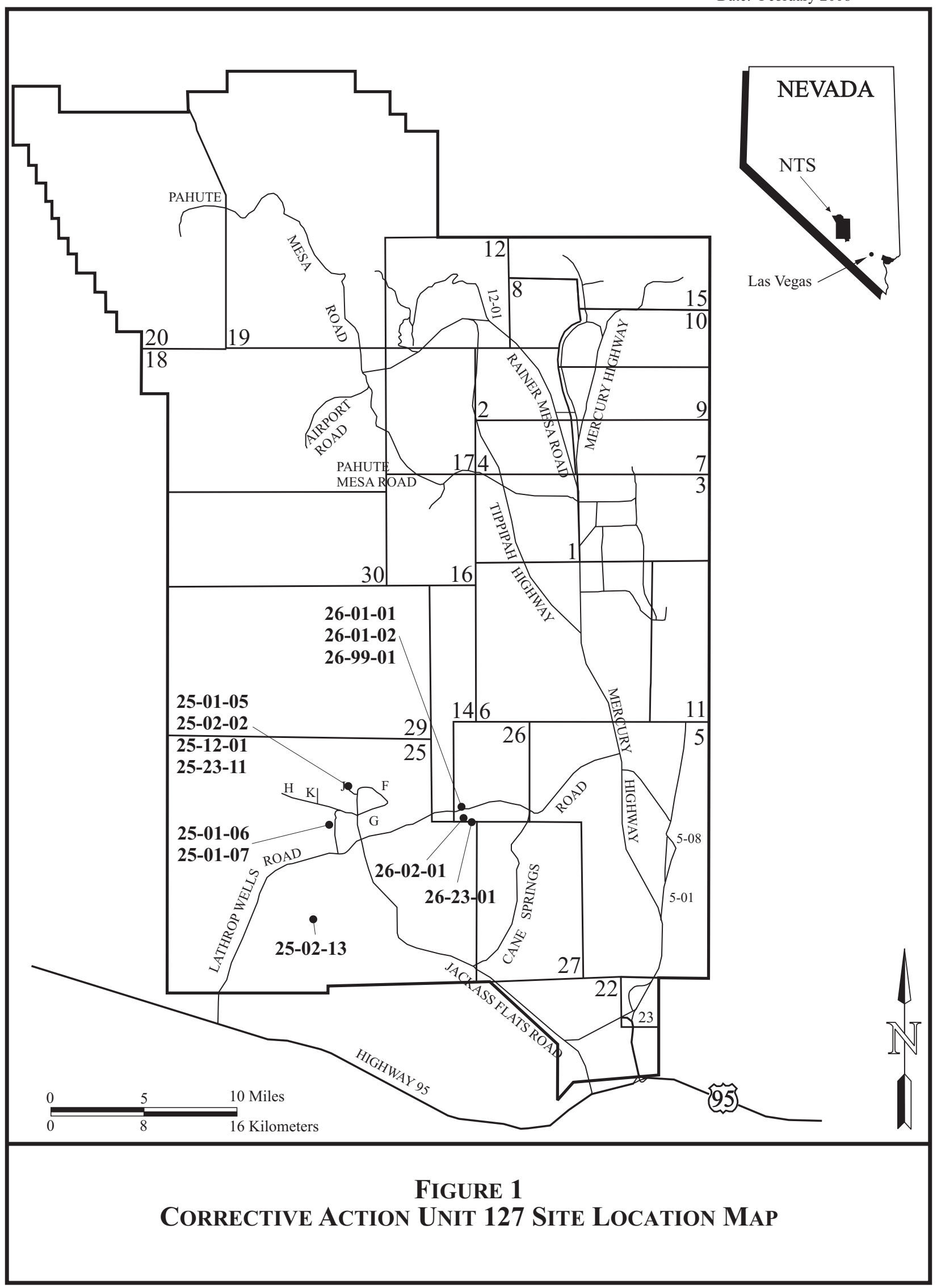


- CAS 25-01-06, Aboveground Storage Tank, was clean closed by removing a 1,000-gal AST and associated piping for disposal as sanitary waste, and total petroleum hydrocarbon (TPH)-impacted soil and AST contents for disposal as hydrocarbon waste.

- CAS 25-01-07, Aboveground Storage Tank, was closed in place with administrative controls. A 1,000-gal AST and associated piping were removed for disposal as sanitary waste, and the top 5 feet (ft) of TPH-impacted soil and AST contents were removed for disposal as hydrocarbon waste. Remaining impacted soil was closed in place, and use restriction (UR) warning signs were posted.

- CAS 25-02-02, Underground Storage Tank, was closed in place with administrative controls. Radiologically contaminated soil and a concrete pad were removed for disposal as LLW, and piping was removed for offsite disposal as MW. Six radiologically contaminated underground storage tanks (USTs) were filled with grout and left in place. UR warning signs were posted.

- CAS 25-02-13, Underground Storage Tank, required no further action, and no work was performed.

- CAS 25-12-01, Boiler, was clean closed by removing cadmium-insulated piping for offsite disposal as hazardous waste (HW) and a boiler for disposal as asbestos-containing material (ACM). Asbestos-insulated piping was left in place for removal when asbestos abatement work takes place for CAU 116, as documented in a Record of Technical Change to the Streamlined Approach for Environmental Restoration Plan for CAU 116.

- CAS 25-23-11, Contaminated Materials, was clean closed by removing radiologically contaminated soil and a metal shed for disposal as LLW. Lead bricks, radiologically and lead-impacted soil, a concrete pump vault, a pump, and piping were removed for offsite disposal as MW.

- CAS 26-01-01, Filter Tank (RAD) and Piping, was clean closed by removing a radiologically contaminated 10,000-gal AST for disposal as LLW. Associated piping and radiologically and lead-impacted soil were removed for offsite disposal as MW.

- CAS 26-01-02, Filter Tank (RAD), was clean closed by removing a radiologically contaminated 5,000-gal AST and associated piping for disposal as LLW.

- CAS 26-02-01, Underground Storage Tank, required no further action. As a best management practice (BMP), the UST was filled with grout.

- CAS 26-23-01, Contaminated Liquids Spreader, was clean closed by removing a spreader and radiologically contaminated soil for disposal as LLW. A lead shield was removed for offsite disposal as MW.

- CAS 26-99-01, Radioactively Contaminated Filters, was clean closed by removing eight radiologically contaminated filter tanks, associated piping, and a wooden shed for disposal as LLW. A polychlorinated biphenyl (PCB) ballast was removed for offsite disposal as PCB waste, a lead brick was removed for offsite disposal as MW, a fluorescent light bulb was removed for offsite disposal as universal waste, and a hydraulic jack was removed for disposal as LLW. 


\subsection{Closure Report Contents}

This CR includes the following sections:

- Section 1.0 - Introduction

- Section 2.0 - Closure Activities

- Section 3.0 - Waste Disposition

- Section 4.0 - Closure Verification Results

- Section 5.0 - Conclusions and Recommendations

- Section 6.0 - References

- Appendix A - Data Quality Objectives

- Appendix B - Sample Analytical Results

- Appendix C - Waste Disposition Documentation

- Appendix D - Use Restriction Documentation

- Appendix E - Site Closure Photographs

- Library Distribution List

This report was developed using information and guidance from the following documents:

- $\quad$ CAP for CAU 127 (NNSA/NSO, 2004b)

- Revision 1 of the Corrective Action Decision Document for CAU 127 (NNSA/NSO, 2004a)

- Industrial Sites Quality Assurance Project Plan (QAPP) (U.S. Department of Energy, National Nuclear Security Administration Nevada Operations Office [NNSA/NV], 2002b)

Data quality objectives developed for site characterization of CAU 127 were presented in Appendix A of the Corrective Action Investigation Plan for CAU 127 (NNSA/NV, 2002a) and are included as Appendix A of this report. Two conceptual site models (CSMs) were developed for CAU 127 based on process knowledge, historical information, and personnel interviews. No variations to the CSMs were identified; the CSMs were confirmed by soil sample results and verified during closure activities. Site closure was verified through inspections, sampling, observations, and documentation of waste disposal. 
This section details the specific activities completed during the closure of CAU 127, deviations from the CAP, the schedule of completed activities, and the final site plan. Photographs in Appendix E document the states of the sites before corrective actions were implemented, field work in progress, and site conditions after completion of work.

\subsection{Description of CoRrective ACtion ACtivities}

Closure activities for CAU 127 were completed according to the CAP (NNSA/NSO, 2004b). The following sections detail the closure activities as completed.

\subsubsection{Preplanning and Site Preparation}

Prior to closure activities, the following documents were prepared:

- National Environmental Policy Act Checklist

- Site-Specific Health and Safety Plan

- Field Management Plan

- NNSA/NSO Real Estate/Operations Permits

- Work control packages

\subsubsection{Closure Activities}

The following sections detail the closure activities completed at each CAS.

\subsubsection{Corrective Action Site 25-01-05, Aboveground Storage Tank}

This site, located at Test Cell C (TCC), consisted of a 100,000-gal AST and associated piping (Figure 2). Clean closure was implemented at the site by removing the AST and associated piping for disposal as LLW.

Removable contamination inside the AST was fixed in place by spraying fixative into the AST. The AST was then demolished and size-reduced using shears. Aboveground piping was cut at the ground surface and removed. The AST debris and piping were packaged in transportainers, are currently being stored and managed onsite, and will be transported to the Area 5 Radioactive Waste Management Site (RWMS) for disposal as LLW. Piping connecting the AST to previously removed pumps is covered by the engineered soil cap of the CAU 262 leachfield. The aboveground piping north of the leachfield was covered with asbestos and cadmium foil. This piping was removed, packaged in a B-25 box, and transported offsite for disposal as MW. The portion of the piping running under the leachfield was grouted.

Two transfer pumps on a concrete pad located north of the leachfield were specified in the CAP for removal. The concrete pad and pumps were not present during closure activities, and it is assumed that they were removed at some date previous to the corrective action investigation. 
Date: February 2008

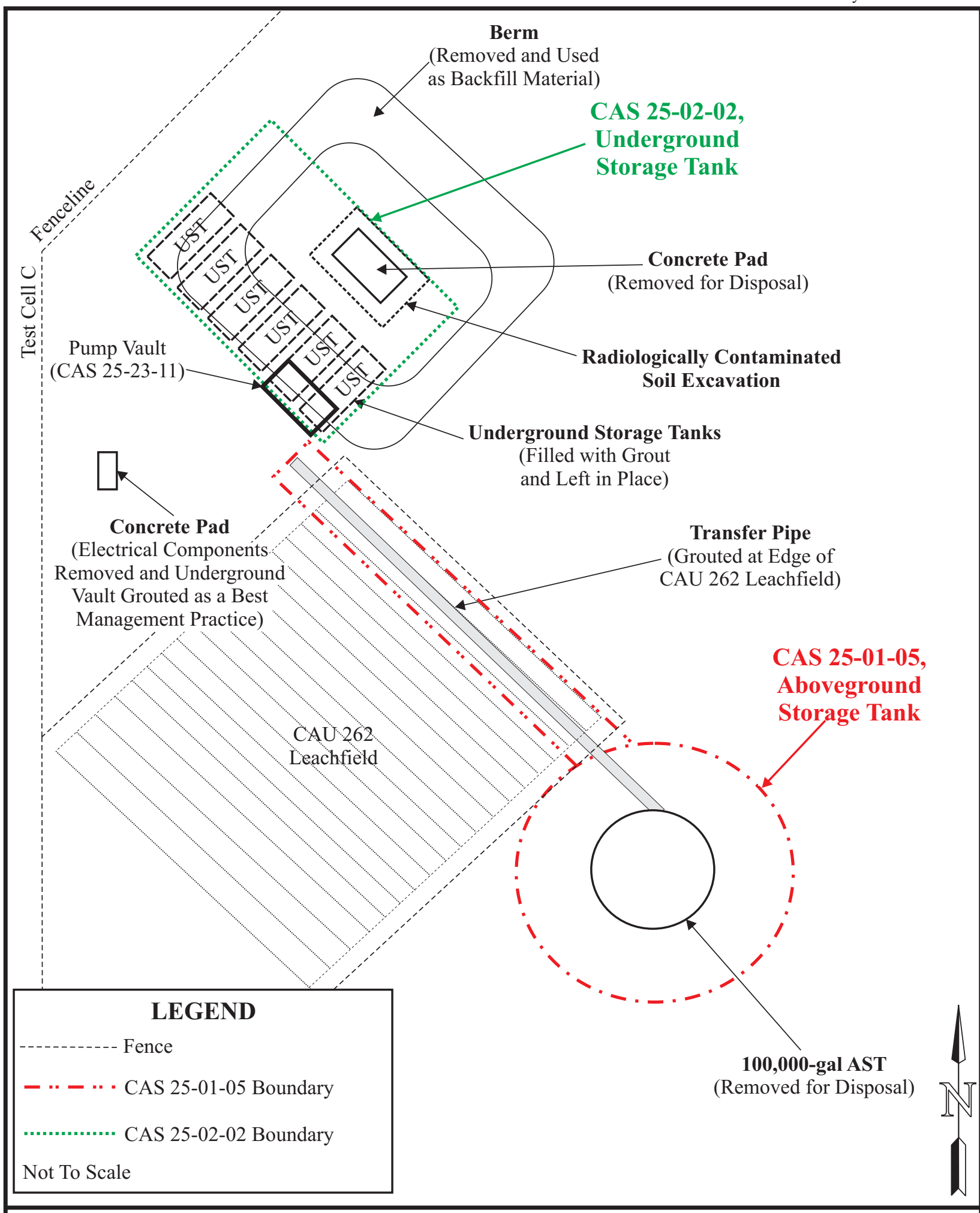

FIGURE 2

Corrective ACtion Site 25-01-05, AbOVeground Storage TANK, AND CoRrective ACTION SITE 25-02-02, UnDERGROUND STORAGE TANK 
A concrete pad housing aboveground electrical components and an underground monitoring vault, components of the TCC waste water treatment system that are not included in any CAU, were discovered north of the leachfield during closure activities. The vault appears to have monitored radiation and volume of effluent passing from the filter tanks to the leachfield. As a BMP, the electrical components located on the concrete pad and piping from the underground vault were removed, and the underground vault was filled with grout. The UR for the adjacent USTs in CAS 25-02-02 was expanded to include the vault.

\subsubsection{Corrective Action Site 25-01-06, Aboveground Storage Tank}

This site, located at the Engine Transport System Maintenance (ETSM) building in the Engine Maintenance, Assembly, and Disassembly (E-MAD) Facility, consisted of a 1,000-gal AST, associated piping, concrete pad, and TPH-impacted soil (Figure 3). Clean closure was implemented at the site by removing the AST, associated piping, and concrete pad for disposal as sanitary waste and TPH-impacted soil for disposal as hydrocarbon waste.

Approximately 10 gal of TPH-impacted liquid were removed from the AST and solidified using clean soil. The AST was removed and compacted using heavy equipment, and the concrete pad was broken up and removed. Approximately 30 cubic yards $\left(\mathrm{yd}^{3}\right)$ of $\mathrm{TPH}$-impacted soil were excavated. The AST contents and soil were transported to the Area 6 Hydrocarbon Landfill for disposal. The AST, piping, and concrete pad were transported to the Area 9 U10c Sanitary Landfill for disposal.

TPH field screening kits were used to guide the extent of the excavation. Five verification samples, one from each side wall and one from the floor of the excavation, and one blind duplicate sample were collected and analyzed for TPH. Verification sample results indicated that the remaining soil did not contain TPH at concentrations above the action level; therefore, the excavation was backfilled with clean soil and contoured to the approximate surrounding grade. A summary of the sample data is included in Section 4.0, and the laboratory data reports are included in Appendix B.

\subsubsection{Corrective Action Site 25-01-07, Aboveground Storage Tank}

This site, located at the ETSM building in the E-MAD Facility, consisted of a 1,000-gal AST, associated piping, concrete pad, and TPH-impacted soil (Figure 4). The site was closed in place with administrative controls. The AST, associated piping, and concrete pad were removed for disposal as sanitary waste, and the top $5 \mathrm{ft}$ of soil were removed for disposal as hydrocarbon waste. The remaining impacted soil was left in place.

Approximately 15 gal of TPH-impacted liquid were removed from the AST and solidified using clean soil. The AST was removed and compacted using heavy equipment, and the concrete pad was broken up and removed. Approximately $20 \mathrm{yd}^{3}$ of TPH-impacted soil were excavated to a depth of approximately $5 \mathrm{ft}$. The AST contents and soil were transported to the Area 6 Hydrocarbon Landfill for disposal. The AST, piping, and concrete pad were transported to the Area 9 U10c Sanitary Landfill for disposal. 


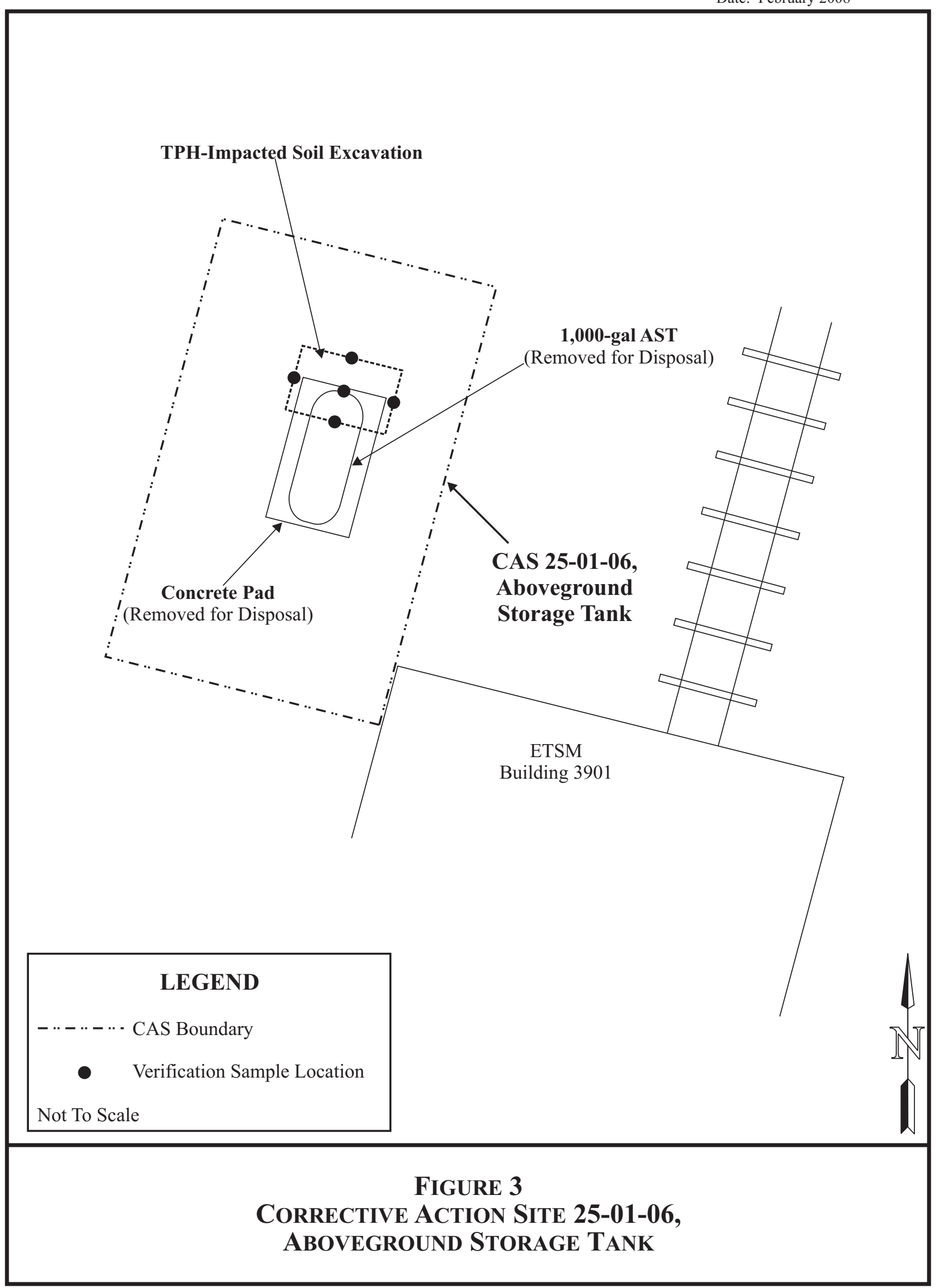


Date: February 2008

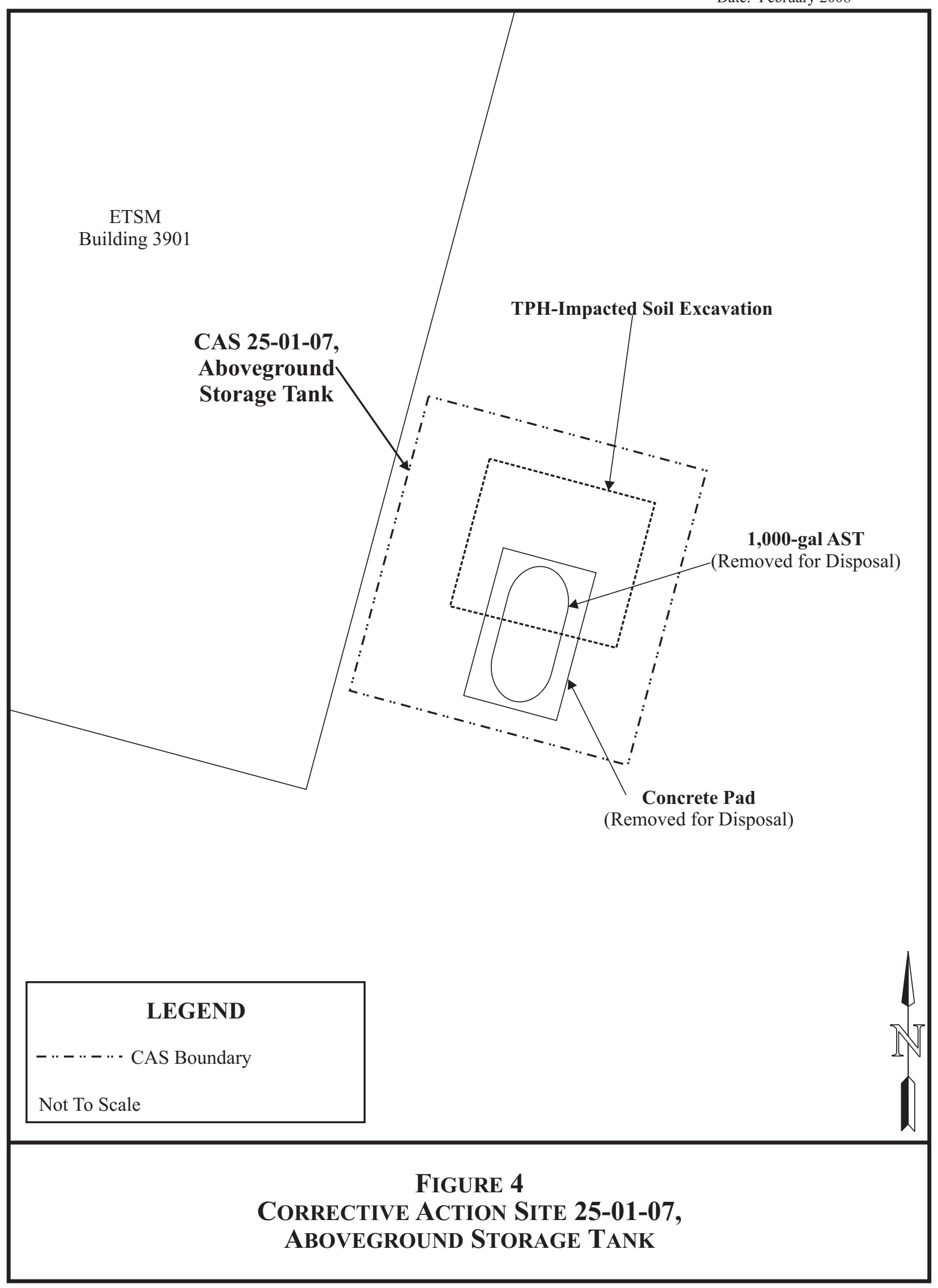


Due to the close proximity of the AST to the ETSM building and the fact that the impacted soil may extend under its structure, the remaining impacted soil was not excavated and was closed in place with administrative controls. Verification samples were not required, as impacted soil was left in place. The excavation was backfilled with clean soil and contoured to the approximate surrounding grade.

A UR was implemented to prohibit unauthorized intrusive activity. UR warning signs were posted. The CAU Use Restriction Information form and a figure showing the locations of the surveyed points delineating the use-restricted area are included in Appendix D. Annual site inspections will be required to ensure that the signs are intact and legible and that the UR is maintained. Details on the post-closure requirements are included in Section 5.2.

\subsubsection{Corrective Action Site 25-02-02, Underground Storage Tank}

This site, located at TCC, consists of six 10,000-gal USTs, associated piping, a concrete pad, and radiologically contaminated soil (Figure 2). The site was closed in place with administrative controls. The radiologically contaminated soil and concrete pad were removed for disposal as LLW, and piping was removed for offsite disposal as MW. The six USTs were filled with grout and left in place.

The concrete pad was located above and to the east of the USTs in the center of a soil berm that was approximately $85 \mathrm{ft}$ long by $75 \mathrm{ft}$ wide by $11.5 \mathrm{ft}$ high. The soil in the berm was removed in order to access the concrete pad and USTs, radiologically surveyed and found to be clean, and stockpiled onsite for use as backfill material. The concrete pad and approximately $10 \mathrm{yd}^{3}$ of radiologically contaminated soil beneath the concrete pad were removed and packaged in a transportainer. The transportainer is currently being stored and managed onsite and will be transported to the Area 5 RWMS for disposal as LLW. Underground piping was removed, packaged in a B-25 box, and transported offsite for disposal as MW.

The depth to the top of each UST was approximately $10 \mathrm{ft}$; however, the top $2.5 \mathrm{ft}$ of soil was considered part of CAS 25-23-11 and was removed for disposal as part of the closure activities for that CAS. The remaining $7.5 \mathrm{ft}$ of overburden on the USTs was excavated, radiologically surveyed and found to be clean, and stockpiled onsite for use as backfill material. The liquid contents of the six USTs were solidified in place with grout, and the remaining void spaces within the USTs were filled with grout. The excavation was backfilled with clean soil.

A UR was implemented to prohibit unauthorized intrusive activity. UR warning signs were posted. The CAU Use Restriction Information form and a figure showing the locations of the surveyed points delineating the use-restricted area are included in Appendix D. Annual site inspections will be required to ensure that the signs are intact and legible and that the UR is maintained. Details on the post-closure requirements are included in Section 5.2.

\subsubsection{Corrective Action Site 25-02-13, Underground Storage Tank}

This site, located at X-Tunnel, consists of gravel and soil at the former location of a UST. No contaminants of concern (COCs) were identified during characterization; therefore, the site was closed by taking no further action. 


\subsubsection{Corrective Action Site 25-12-01, Boiler}

Date: February 2008

This site, located at TCC, consisted of a boiler, approximately $100 \mathrm{ft}$ of asbestos-insulated piping, and approximately $10 \mathrm{ft}$ of cadmium- and asbestos-insulated piping (Figure 5). Clean closure was implemented at the site by removing the boiler for disposal as ACM and the cadmium-insulated piping for offsite disposal as HW. The asbestos-insulated piping was left in place and will be removed when asbestos abatement work takes place for CAU 116. This agreement was documented in a Record of Technical Change to the Streamlined Approach for Environmental Restoration Plan for CAU 116, which was approved by the Nevada Division of Environmental Protection (NDEP) on October 19, 2007 (NNSA/NSO, 2006).

A support structure was constructed to support the asbestos-insulated piping that would be left in place after the boiler was removed. The cadmium-insulated piping was then removed, packaged in a drum, and transported to the Area 5 HW Storage Pad, where it is currently being stored and managed. The drum will be transported offsite for disposal as HW. The boiler was then filled with sand to prevent collapse and stabilize asbestos tiles present in the tank, removed, and transported to the Area 23 Sanitary Landfill for disposal.

\subsubsection{Corrective Action Site 25-23-11, Contaminated Materials}

This site, located above the USTs associated with CAS 25-02-02 at TCC, consisted of a metal pump shed, concrete pump vault, pump, piping, lead bricks, radiologically and lead-impacted soil, and radiologically contaminated soil (Figure 6). Clean closure was implemented at the site by removing the metal shed and soil for disposal as LLW and the lead bricks, vault, pump, piping, and soil for offsite disposal as MW.

The metal pump shed was removed, size-reduced, and packaged in transportainers. The transportainers are currently being stored and managed onsite and will be transported to the Area 5 RWMS for disposal as LLW. The lead bricks, radiologically and lead-impacted soil, and pump were removed from the concrete pump vault and packaged in a B-25 box as MW. The concrete pump vault was then removed, size-reduced, and packaged in B-25 boxes as MW. The MW was transported offsite for treatment and disposal. Approximately $50 \mathrm{yd}^{3}$ of radiologically contaminated soil from around the concrete pump vault were excavated to a depth of approximately $2.5 \mathrm{ft}$ and packaged in transportainers. The soil is currently being stored and managed onsite and will be transported to the Area 5 RWMS for disposal as LLW.

Ten verification samples, two from each side wall and two from the floor of the excavation, were collected and analyzed for cesium-137. Verification sample results indicated that the remaining soil in the side walls of the excavation did not contain cesium-137 at concentrations above the action level; therefore, the excavation was backfilled with clean soil and contoured to the approximate surrounding grade. The two verification samples collected from the floor of the excavation exceeded the action level for cesium-137; however, the floor of the excavation was the interface of CAS 25-02-02, which was closed in place, so no additional excavation was required. A summary of the sample data is included in Section 4.0, and the laboratory data reports are included in Appendix B. 


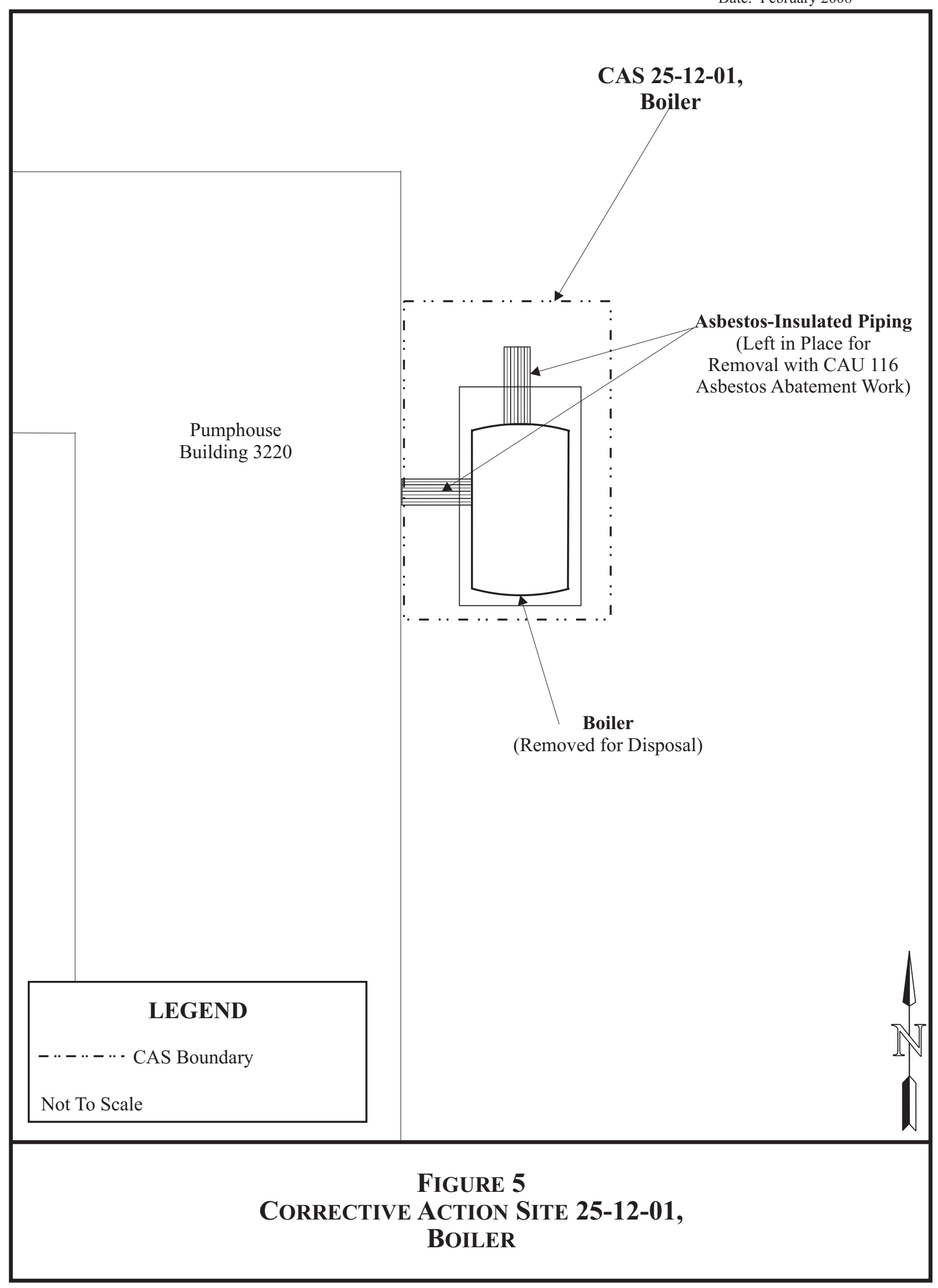




\section{Cross-Sectional View}

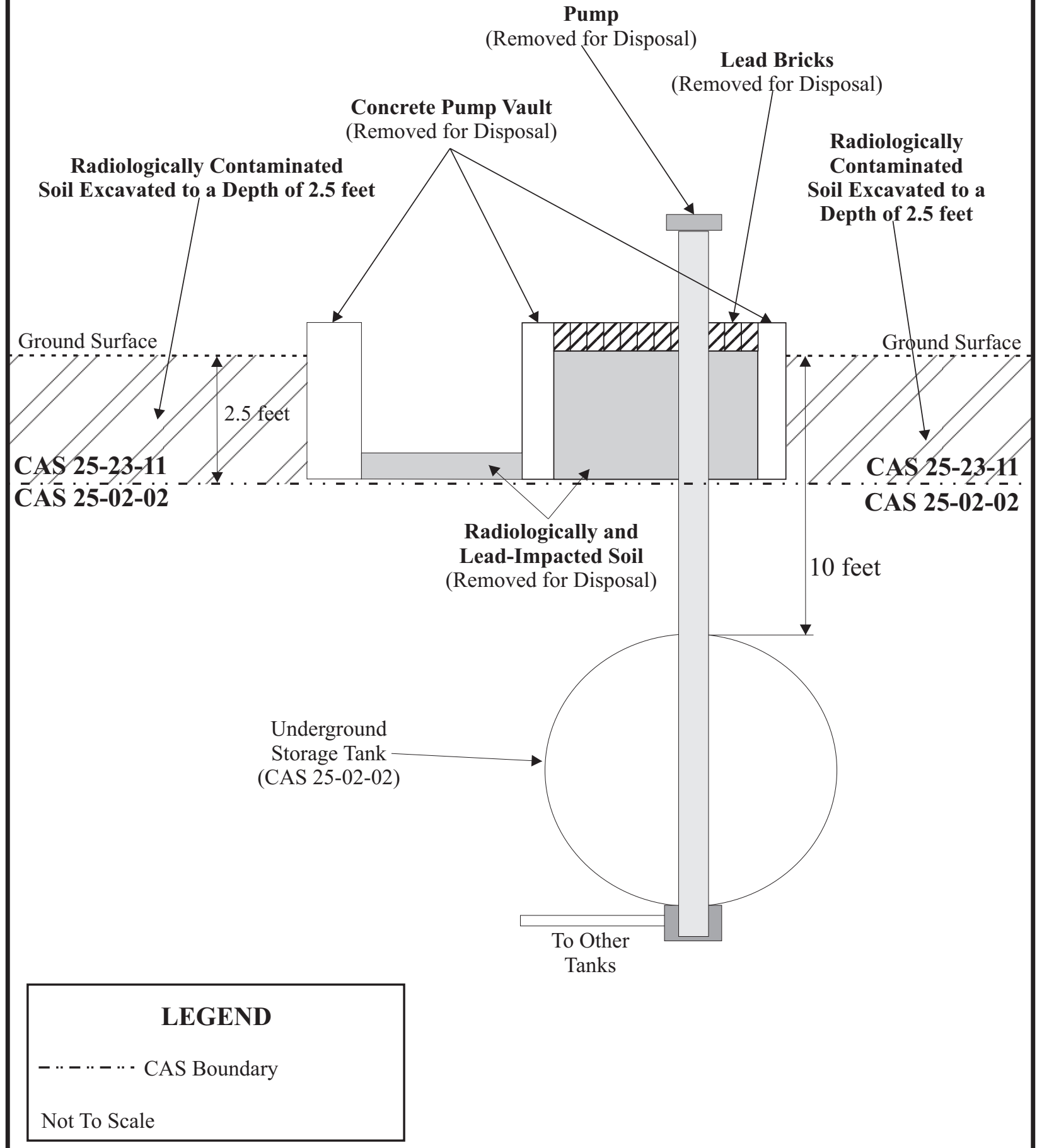

FIGURE 6

CORRECTIVE ACTION SITE 25-23-11, CONTAMINATED MATERIALS 


\subsubsection{Corrective Action Site 26-01-01, Filter Tank (RAD) and Piping}

This site, located at the Pluto Disassembly Facility, consisted of a 10,000-gal AST, associated piping, and radiologically and lead-impacted soil (Figure 7). Clean closure was implemented at the site by removing the AST for disposal as LLW and associated piping and radiologically and lead-impacted soil for offsite disposal as MW.

Approximately $6 \mathrm{yd}^{3}$ of radiologically and lead-impacted soil were excavated, packaged in B-25 boxes, and transported offsite for disposal as MW. The aboveground piping, which was found to contain lead components, was removed from the AST, packaged in a B-25 box, and transported offsite for disposal as MW. The AST is currently being stored and managed onsite and will be transported to the Area 5 RWMS, where it will be filled with clean soil and disposed as LLW. Underground piping was grouted.

Five verification samples, one from each side wall and one from the floor of the radiologically and lead-impacted soil excavation, were collected and analyzed for total lead. The samples were not required to be analyzed for radiological isotopes because, although the excavated soil was radiologically contaminated, it did not exceed the action levels for any radiological constituents. Verification sample results indicated that the remaining soil did not contain lead at concentrations above the action level; therefore, the excavation was backfilled with clean soil and contoured to the approximate surrounding grade. A summary of the sample data is included in Section 4.0, and the laboratory data reports are included in Appendix B.

\subsubsection{Corrective Action Site 26-01-02, Filter Tank (RAD)}

This site, located at the Pluto Disassembly Facility, consisted of a 5,000-gal AST and associated piping (Figure 7). Clean closure was implemented at the site by removing the AST and associated piping for disposal as LLW.

The aboveground piping was removed and packaged for disposal. All openings in the AST were sealed, and the AST was removed from its wooden cradle and packaged in a transportainer. The waste is currently being stored and managed onsite and will be transported to the Area 5 RWMS for disposal as LLW. Underground piping was grouted.

\subsubsection{Corrective Action Site 26-02-01, Underground Storage Tank}

This site, located at the Pluto Check Station, consists of a 1,000-gal UST. No COCs were identified, and no further action was required. However, as a BMP, the UST was filled with grout.

\subsubsection{Corrective Action Site 26-23-01, Contaminated Liquids Spreader}

This site, located near the Port Gaston Training Area, consisted of a radiologically contaminated liquid spreader mounted on a trailer (Figure 8). A lead shield was mounted on the spreader. Clean closure was implemented at the site by removing the spreader for disposal as LLW and the lead shield and radiologically contaminated soil for offsite disposal as MW. 
Date: February 2008

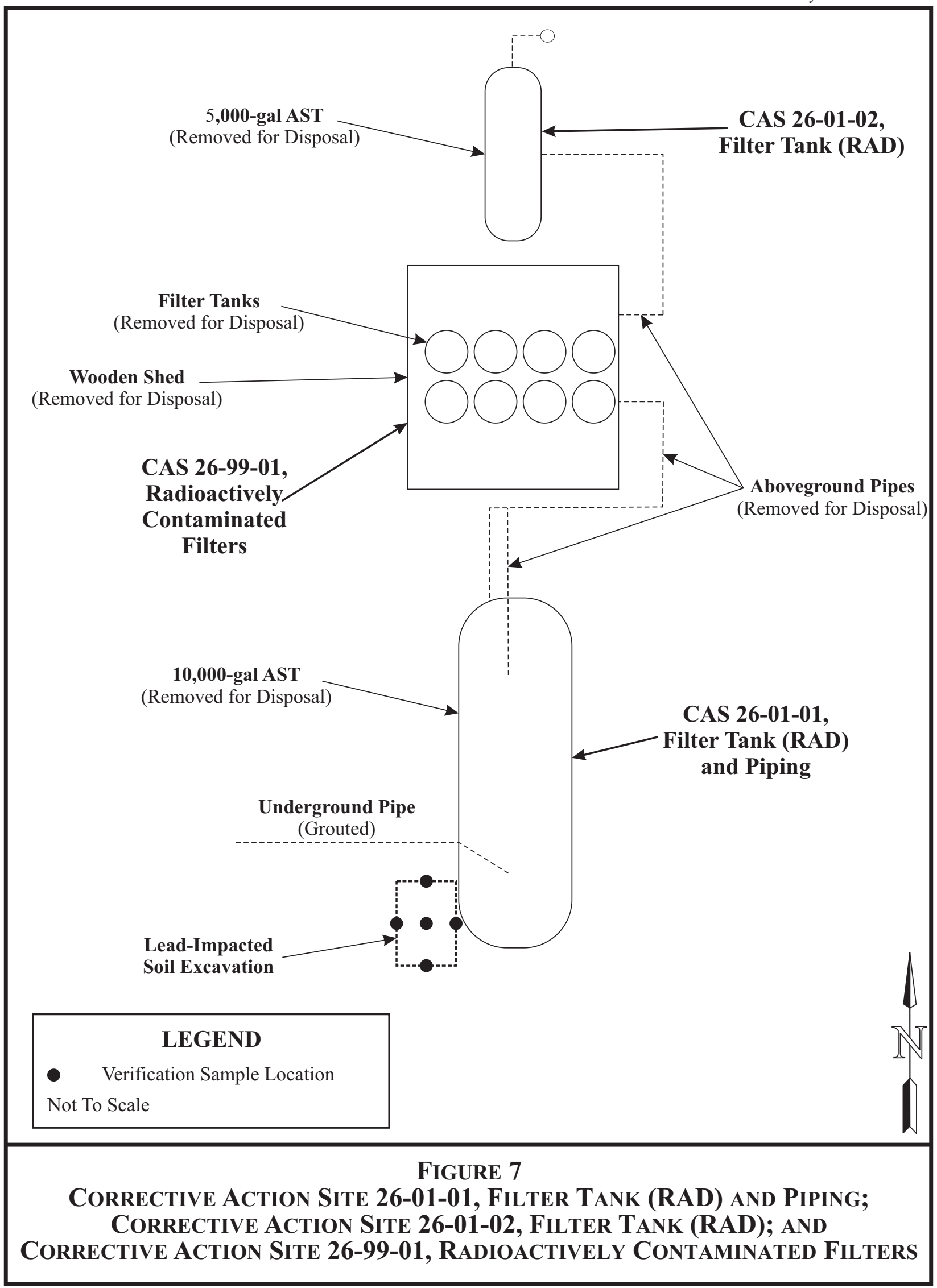




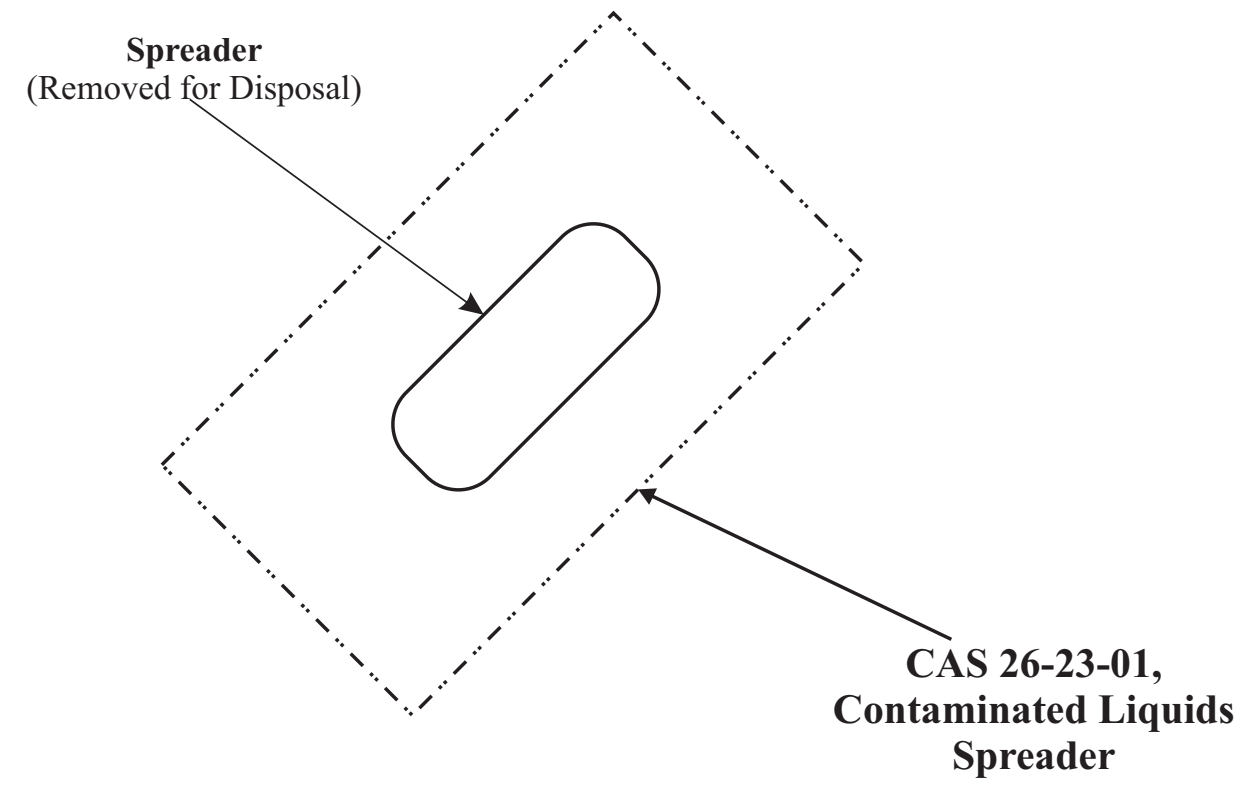

LEGEND

$-\cdot-\cdots-\cdots$ CAS Boundary

Not To Scale

FigURE 8

CORRECTIVE ACTION Site 26-23-01, CONTAMINATED LIQUIDS SPREADER 
The lead shield was removed from the spreader, packaged in a B-25 box, and transported offsite for disposal as MW. The spreader was disassembled and packaged in a transportainer. Approximately $2 \mathrm{yd}^{3}$ of soil containing radiological isotopes below action levels were excavated as a BMP and packaged in the transportainer with the spreader. The transportainer is currently being stored and managed onsite and will be transported to the Area 5 RWMS for disposal as LLW.

\subsubsection{Corrective Action Site 26-99-01, Radioactively Contaminated Filters}

This site, located at the Pluto Disassembly Facility, consisted of eight 30-gal filter tanks located in a wooden shed and associated piping (Figure 7). Clean closure was implemented at the site by removing the filter tanks, shed, and piping for disposal as LLW.

The piping connecting the tanks was removed and packaged for disposal. The tanks were removed from the shed, and all openings in the tanks were sealed. The wooden shed was demolished and packaged with the tanks in a transportainer. The transportainer is currently being stored and managed onsite and will be transported to the Area 5 RWMS for disposal as LLW.

During demolition of the wooden shed, four previously unidentified items were discovered, including PCB ballast, a lead brick, a fluorescent light bulb, and a hydraulic jack. The PCB ballast was transported to the Area $5 \mathrm{HW}$ Storage Pad and will be sent offsite for disposal as PCB waste. The lead brick was packaged in a B-25 box and transported offsite for disposal as MW. The fluorescent light bulb is being stored at the Area 23 universal waste collection center and will be sent offsite for disposal. The hydraulic jack was placed in the transportainer with the shed and tanks, which will be transported to the Area 5 RWMS for disposal as LLW.

\subsection{Deviations from the Corrective Action Plan as Approved}

The CAP states that radiologically contaminated soil will be removed and verification samples will be collected to verify clean closure at CAS 26-23-01 (Contaminated Liquids Spreader). Revision 1 of the Corrective Action Decision Document was written to clarify that the radionuclides in the soil at were below the action levels, and excavation of the soil and collection of verification samples were not necessary. As a BMP, approximately $2 \mathrm{yd}^{3}$ of soil containing radiological isotopes below action levels were excavated and packaged in a transportainer; however, per Revision 1 of the Corrective Action Decision Document, no verification samples were required. The soil is currently being stored and managed onsite and will be transported to the Area 5 RWMS for disposal as LLW.

No other deviations from the CAP (NNSA/NSO, 2004b) were necessary. 


\subsection{Corrective Action Schedule As Completed}

Closure activities began in January 2007 and were completed in January 2008. Details of the schedule are provided in Table 2.

Table 2. Corrective Action Unit 127 Closure Activities Schedule

\begin{tabular}{|l|l|l||}
\hline \multicolumn{1}{|c|}{ CoRRECTIVE ACTION SITE } & \multicolumn{1}{c|}{ START DATE } & \multicolumn{1}{c|}{ END DATE } \\
\hline \hline 25-01-05, Aboveground Storage Tank & January 11, 2007 & August 15, 2007 \\
\hline 25-01-06, Aboveground Storage Tank & March 22, 2007 & April 4, 2007 \\
\hline 25-01-07, Aboveground Storage Tank & March 22, 2007 & April 4, 2007 \\
\hline 25-02-02, Underground Storage Tank & May 9, 2007 & September 25, 2007 \\
\hline 25-12-01, Boiler & August 1, 2007 & August 8, 2007 \\
\hline 25-23-11, Contaminated Materials & May 9, 2007 & August 14, 2007 \\
\hline 26-01-01, Filter Tank (RAD) and Piping & June 26, 2007 & September 13, 2007 \\
\hline 26-01-02, Filter Tank (RAD) & June 26, 2007 & July 2, 2007 \\
\hline 26-02-01, Underground Storage Tank & April 4, 2007 & April 4, 2007 \\
\hline 26-23-01, Contaminated Liquids Spreader & May 3, 2007 & September 13, 2007 \\
\hline 26-99-01, Radioactively Contaminated Filters & June 26, 2007 & July 10, 2007 \\
\hline \hline
\end{tabular}

\subsection{Site Plan/Survey Plat}

CAS 25-01-07 (Aboveground Storage Tank) and CAS 25-02-02 (Underground Storage Tank) were closed in place with administrative controls, and URs were implemented. Figures showing the locations of the surveyed points delineating the UR areas are included in Appendix D. 
This section describes the waste streams generated during closure activities and their final disposition. Waste streams included sanitary waste, ACM waste, hydrocarbon waste, HW, LLW, and MW. Waste disposition is summarized in Table 3 and discussed in detail in the following sections. Waste disposition documentation is included as Appendix C.

\subsection{WASTE Minimization}

Industry standard waste minimization practices were applied throughout the course of closure activities. These practices included the following:

- Radiological surveys of debris to characterize and segregate waste streams

- $\quad$ TPH field screening kits to guide the extents of the excavations for TPH-impacted soil

- Size reduction of debris

\subsection{WASte MANAGEMENT}

All waste was managed according to applicable federal and state regulations, U.S. Department of Energy orders, and company procedures. Waste management areas (WMAs) were established throughout the project, as needed. All WMAs were identified with appropriate signs and boundaries to restrict unauthorized access. The WMAs were inspected on a weekly or monthly basis, as required, to ensure that all containers were intact, not leaking, and not exceeding storage duration times. Applicable WMAs were posted as Radioactive Materials Areas (RMAs) whenever radiological waste was stored in the area. Upon removal of radiologically contaminated waste, the RMA was surveyed and de-posted.

Waste containers were purchased either new or reconditioned. Prior to use, all containers were inspected to verify that they were in good condition (e.g., no leaks, rust, or dents), lined or made of material that would not react with the waste, and in compliance with U.S. Department of Transportation requirements. The containers remained closed while stored unless waste was being added. Containers were also handled in such a manner that the integrity of the container was not compromised. Appropriate labels were affixed, and relevant information was marked on the containers with an indelible marker. All information was legible and clearly visible.

\subsection{WASTE ChaRACTERIZATION}

Waste streams were characterized according to company procedures. Waste was screened for radiological contamination using radiological field survey instruments. 
TABle 3. Corrective ACTION UNIT 127 WASTE Disposition SUMMARY

\begin{tabular}{|c|c|c|c|c|c|}
\hline $\begin{array}{l}\text { WASTE } \\
\text { STREAM }\end{array}$ & CoRRECTIVE ACTION Site & DESCRIPTION OF WASTE & WASTE CONTAINER & VOLUME & DISPOSITION \\
\hline \multirow{2}{*}{ Sanitary Waste } & 25-01-06, Aboveground Storage Tank & AST, Piping, and Concrete & No waste container necessary & $5 \mathrm{yd}^{3}$ & \multirow{2}{*}{$\begin{array}{l}\text { Disposed of at the Area } 9 \text { U10c } \\
\text { Sanitary Landfill }\end{array}$} \\
\hline & 25-01-07, Aboveground Storage Tank & AST, Piping, and Concrete & No waste container necessary & $5 \mathrm{yd}^{3}$ & \\
\hline ACM Waste & 25-12-01, Boiler & Boiler & No waste container necessary & $5 \mathrm{yd}^{3}$ & $\begin{array}{l}\text { Disposed of at the Area } 23 \\
\text { Sanitary Landfill }\end{array}$ \\
\hline \multirow{2}{*}{$\begin{array}{l}\text { Hydrocarbon } \\
\text { Waste }\end{array}$} & 25-01-06, Aboveground Storage Tank & Soil and AST Contents & No waste container necessary & $30 \mathrm{yd}^{3}$ & \multirow{2}{*}{$\begin{array}{l}\text { Disposed of at the Area } 6 \\
\text { Hydrocarbon Landfill }\end{array}$} \\
\hline & 25-01-07, Aboveground Storage Tank & Soil and AST Contents & No waste container necessary & $20 \mathrm{yd}^{3}$ & \\
\hline HW & 25-12-01, Boiler & Cadmium-Insulated Piping & 55-gal drum & 55 gal & $\begin{array}{l}\text { Staged at the Area } 5 \mathrm{HW} \\
\text { Storage Pad for offsite disposal }\end{array}$ \\
\hline \multirow{7}{*}{ LLW } & 25-01-05, Aboveground Storage Tank & AST and Piping Debris & \multirow{3}{*}{ Transportainers } & $400 \mathrm{yd}^{3}$ & \multirow{7}{*}{$\begin{array}{l}\text { Staged onsite for disposal at the } \\
\text { Area } 5 \text { RWMS }\end{array}$} \\
\hline & 25-02-02, Underground Storage Tank & Soil and Concrete & & $15 \mathrm{yd}^{3}$ & \\
\hline & 25-23-11, Contaminated Materials & Soil and Metal Shed & & $100 \mathrm{yd}^{3}$ & \\
\hline & 26-01-01, Filter Tank (RAD) and Piping & AST & Self-Contained & 10,000 gal & \\
\hline & 26-01-02, Filter Tank (RAD) & AST and Piping & Transportainer & $50 \mathrm{yd}^{3}$ & \\
\hline & 26-23-01, Contaminated Liquids Spreader & Spreader and Soil & Transportainer & $50 \mathrm{yd}^{3}$ & \\
\hline & $\begin{array}{l}\text { 26-99-01, Radioactively Contaminated } \\
\text { Filters }\end{array}$ & $\begin{array}{l}\text { Filter Tanks, Piping, and } \\
\text { Wooden Shed }\end{array}$ & Transportainer & $50 \mathrm{yd}^{3}$ & \\
\hline \multirow{6}{*}{ MW } & 25-01-05, Aboveground Storage Tank & $\begin{array}{l}\text { Cadmium- and Asbestos- } \\
\text { Insulated Piping }\end{array}$ & \multirow[t]{2}{*}{ B-25 Box \#187073 } & \multirow[t]{2}{*}{$4 \mathrm{yd}^{3}$} & \multirow{6}{*}{$\begin{array}{l}\text { Transported to an offsite facility } \\
\text { for treatment and disposal }\end{array}$} \\
\hline & 25-02-02, Underground Storage Tank & Piping & & & \\
\hline & 25-23-11, Contaminated Materials & $\begin{array}{l}\text { Lead Bricks, Vault, Pump, } \\
\text { Piping, and Soil }\end{array}$ & B-25 Box \#151444 & $4 \mathrm{yd}^{3}$ & \\
\hline & \multirow{2}{*}{ 26-01-01, Filter Tank (RAD) and Piping } & Soil & B-25 Box \#151474 & $4 \mathrm{yd}^{3}$ & \\
\hline & & Soil and Piping & B-25 Box \#131092 & $4 \mathrm{yd}^{3}$ & \\
\hline & 26-23-01, Contaminated Liquids Spreader & Lead Shield & B-25 Box \#151473 & $4 \mathrm{yd}^{3}$ & \\
\hline \multicolumn{6}{|c|}{$\begin{array}{ll}\text { ACM: asbestos-containing material } & \text { LLW: low-level waste } \\
\text { AST: aboveground storage tank } & \text { MW: mixed waste } \\
\text { gal: gallon(s) } & \text { RWMS: Radioactive } \\
\text { HW: hazardous waste } & \mathrm{yd}^{3} \text { : cubic yard(s) }\end{array}$} \\
\hline
\end{tabular}




\subsection{WASTE STREAMS AND Disposal}

Waste streams generated during closure activities at CAU 127 included sanitary waste, ACM waste, hydrocarbon waste, HW, LLW, and MW. Waste disposition documentation is included as Appendix C.

\subsubsection{Sanitary Waste}

Sanitary waste was generated at CAS 25-01-06 (Aboveground Storage Tank) and CAS 25-01-07 (Aboveground Storage Tank). The ASTs and concrete pads from CASs 25-01-06 and 25-01-07 were transported in end-dump trucks to the Area 9 U10c Sanitary Landfill for disposal.

\subsubsection{Asbestos-Containing Material}

ACM waste was generated at CAS 25-12-01 (Boiler). The boiler was considered ACM because asbestos tiles were present in the boiler. The boiler was transported in an end-dump truck to the Area 23 Sanitary Landfill for disposal.

\subsubsection{Hydrocarbon Waste}

Hydrocarbon waste was generated at CAS 25-01-06 (Aboveground Storage Tank) and CAS 25-01-07 (Aboveground Storage Tank). TPH-impacted soil and AST contents from CASs 25-01-06 and 25-01-07 were transported in end-dump trucks to the Area 6 Hydrocarbon Landfill for disposal.

\subsubsection{Hazardous Waste}

HW was generated at CAS 25-12-01 (Boiler). Cadmium- and asbestos-insulated piping was packaged in a 55-gal drum and transported to the Area 5 HW Storage Pad, where it is currently being stored and managed. The drum will be transported offsite for disposal.

\subsubsection{Low-Level Waste}

A total of approximately $700 \mathrm{yd}^{3}$ of LLW was generated during closure activities. LLW is currently being staged and managed onsite and will be transported to the Area 5 RWMS for disposal.

\subsubsection{Mixed Waste}

A total of approximately $20 \mathrm{yd}^{3}$ of MW was generated during closure activities. MW was packaged in B-25 boxes and transported to a permitted offsite facility for treatment and disposal. 
Revision: 0

Date: February 2008

THIS PAGE INTENTIONALLY LEFT BLANK 


\subsection{CLOSURE VERIFICATION RESULTS}

To verify that CAU 127 closure activities met cleanup criteria, soil verification samples were collected and analyzed at three CASs. The results showed that no COCs above the action levels remained at the sites. Sample results are summarized in Table 4 through Table 6, and the laboratory data reports are included in Appendix B.

\subsection{Data Quality Assessment}

Accurate and defensible analytical data were collected to verify that waste and verification samples were properly characterized, managed, and disposed during CAU 127 closure activities. The following sections describe the quality assurance (QA)/quality control (QC) procedures, data validation process, and a reconciliation of the CSM with actual findings during CAU 127 closure activities. More detail on the QA/QC procedures for CAU 127 can be found in the CAP for CAU 127 (NNSA/NSO, 2004b).

\subsubsection{Quality Assurance/Quality Control Procedures}

Verification and waste characterization samples were collected with disposable polyethylene scoops and placed in appropriately labeled sample containers secured with custody seals. All samples were labeled with a unique sample number, placed on ice, and transported under a chain of custody. Standard QA/QC samples were collected (i.e., one blind duplicate per twenty samples). Samples were analyzed by certified offsite contract laboratories. Analytical results were validated at the laboratory using stringent QA/QC procedures, including matrix spike/matrix spike duplicates, spiked surrogate recovery analysis, verification of analytical results, and data quality indicator requirements. Detailed information regarding the QA/QC program requirements can be found in the Industrial Sites QAPP (NNSA/NV, 2002b).

\subsubsection{Data Validation}

Data validation was performed according to the Industrial Sites QAPP (NNSA/NV, 2002b), which is based on the U.S. Environmental Protection Agency (EPA) functional guidelines for data quality (EPA, 1994; 1999). Data were reviewed to ensure that samples were appropriately processed and analyzed and that the results are valid. All sample data were internally validated at the Tier I and Tier II levels. No anomalies were discovered in the data that would discredit any of the waste characterization or verification sample results. While only summary laboratory QC data for verification samples are included in Appendix B, the complete data set, including validation reports for waste characterization and verification samples, is maintained in the project files and available upon request.

\subsubsection{Conceptual Site Models}

Two CAU 127 CSMs were developed and were presented in the approved Corrective Action Investigation Plan for CAU 127 (NNSA/NV, 2002a). A detailed description of the CSMs is presented in Section 1.3.1. All CSMs were confirmed by soil sample results and verified during closure activities. 
Table 4. Corrective ACtion Site 25-01-06, Aboveground Storage Tank, VERIFICATION SAMPLE RESULTS

\begin{tabular}{|c|c|c|c|c|}
\hline \multirow{2}{*}{$\begin{array}{c}\text { DATE } \\
\text { COLLECTED }\end{array}$} & \multirow{2}{*}{$\begin{array}{c}\text { SAMPLE } \\
\text { DELIVERY } \\
\text { GROUP }\end{array}$} & \multirow{2}{*}{$\begin{array}{l}\text { SAMPLE } \\
\text { NUMBER }\end{array}$} & TPH DRO (mg/kg) & TPH GRO (mg/kg) \\
\hline & & & Action Level $=100$ & Action Level $=100$ \\
\hline \multirow{6}{*}{ 04/03/2007 } & \multirow{6}{*}{ V2886 } & 25-01-06-V1 & ND & ND \\
\hline & & 25-01-06-V2 & 3.80 & ND \\
\hline & & 25-01-06-V3 & 6.90 & ND \\
\hline & & 25-01-06-V4 & 3.49 & ND \\
\hline & & 25-01-06-V5 & 3.50 & ND \\
\hline & & 25-01-06-V6 & 3.90 & ND \\
\hline
\end{tabular}

DRO: diesel range organics

GRO: gasoline range organics

$\mathrm{mg} / \mathrm{kg}$ : milligram(s) per kilogram

ND: not detected above minimum laboratory detection limits

TPH: total petroleum hydrocarbons

\section{Table 5. Corrective ACtion Site 25-23-13, Contaminated Materials, VERIFICATION SAMPLE RESULTS}

\begin{tabular}{|c|c|c|c|c|}
\hline \multirow{2}{*}{$\begin{array}{c}\text { DATE } \\
\text { COLLECTED }\end{array}$} & \multirow{2}{*}{$\begin{array}{c}\text { SAMPLE } \\
\text { DELIVERY } \\
\text { GROUP }\end{array}$} & \multirow{2}{*}{$\begin{array}{l}\text { SAMPLE } \\
\text { NUMBER }\end{array}$} & \multirow{2}{*}{ SAMPLE LOCATION } & CESIUM-137 (pCi/g) \\
\hline & & & & Action Level = 7.32 \\
\hline \multirow{10}{*}{ 06/21/2007 } & \multirow{10}{*}{ V2936 } & 252311-V1 & Sidewall 1 & 0.732 \\
\hline & & 252311-V2 & Sidewall 1 & 0.388 \\
\hline & & 252311-V3 & Sidewall 2 & 0.088 \\
\hline & & 252311-V4 & Sidewall 2 & 0.945 \\
\hline & & 252311-V5 & Sidewall 3 & 0.596 \\
\hline & & 252311-V6 & Sidewall 3 & 0.692 \\
\hline & & 252311-V7 & Sidewall 4 & 0.612 \\
\hline & & 252311-V8 & Sidewall 4 & 1.02 \\
\hline & & 252311-V9 & Floor of Excavation & $8.69 *$ \\
\hline & & 252311-V10 & Floor of Excavation & $10.07^{*}$ \\
\hline
\end{tabular}

pCi/g: picocurie(s) per gram

* The floor of the excavation is the interface with CAS 25-02-02, which was closed in place with administrative controls. 
TAble 6. Corrective ACtion Site 26-01-01, Filter TANK (RAD) AND PiPING, VERIFICATION SAMPLE RESULTS

\begin{tabular}{|c|c|c|c|}
\hline \multirow{2}{*}{$\begin{array}{c}\text { DATE } \\
\text { COLLECTED }\end{array}$} & \multirow{2}{*}{$\begin{array}{c}\text { SAMPLE DELIVERY } \\
\text { GROUP }\end{array}$} & \multirow{2}{*}{ SAMPLE NUMBER } & LEAD (mg/kg) \\
\hline & & & Action Level $=750$ \\
\hline \multirow{5}{*}{ 07/16/2007 } & \multirow{5}{*}{ V2948 } & 260101-V1 & 12.7 \\
\hline & & 260101-V2 & 18.0 \\
\hline & & 260101-V3 & 7.9 \\
\hline & & 260101-V4 & 12.3 \\
\hline & & 260101-V5 & 13.0 \\
\hline
\end{tabular}

mg/kg: milligram(s) per kilogram

\subsection{USE RESTRICTIONS}

URs have been implemented for the following CASs:

- CAS 25-01-07, Aboveground Storage Tank

- CAS 25-02-02, Underground Storage Tank

\subsubsection{Corrective Action Site 25-01-07, Aboveground Storage Tank}

At this site, a UR was implemented for TPH-impacted soil. UR warning signs were posted to warn against intrusive activity according to the FFACO UR posting guidance (FFACO, 2003). The CAU Use Restriction Information form and a figure showing the locations of the surveyed points delineating the UR area are included in Appendix D. Annual site inspections will be required to ensure that the signs are intact and legible and that the UR is maintained. Details on the post-closure requirements are included in Section 5.2.

\subsubsection{Corrective Action Site 25-02-02, Underground Storage Tank}

At this site, a UR was implemented for radiologically contaminated USTs. UR warning signs were posted to warn against intrusive activity according to the FFACO UR posting guidance (FFACO, 2003). The CAU Use Restriction Information form and a figure showing the locations of the surveyed points delineating the UR area are included in Appendix D. Annual site inspections will be required to ensure that the signs are intact and legible and that the UR is maintained. Details on the post-closure requirements are included in Section 5.2. 
CAU 127 Closure Report

Section: Closure Verification

Revision: 0

Date: February 2008

THIS PAGE INTENTIONALLY LEFT BLANK 


\subsection{CONCLUSIONS AND RECOMMENDATIONS}

\subsection{CONCLUSIONS}

The following site closure activities were performed at CAU 127 and are documented in this CR:

- CAS 25-01-05, Aboveground Storage Tank, was clean closed by removing a 100,000-gal AST and associated aboveground piping for disposal as LLW. Cadmium- and asbestosinsulated piping was removed for offsite disposal as MW.

- CAS 25-01-06, Aboveground Storage Tank, was clean closed by removing a 1,000-gal AST and associated piping for disposal as sanitary waste, and TPH-impacted soil and AST contents for disposal as hydrocarbon waste.

- CAS 25-01-07, Aboveground Storage Tank, was closed in place with administrative controls. A 1,000-gal AST and associated piping were removed for disposal as sanitary waste, and the top $5 \mathrm{ft}$ of TPH-impacted soil and AST contents were removed for disposal as hydrocarbon waste. Remaining impacted soil was closed in place, and UR warning signs were posted.

- CAS 25-02-02, Underground Storage Tank, was closed in place with administrative controls. Radiologically contaminated soil and a concrete pad were removed for disposal as LLW, and piping was removed for offsite disposal as MW. Six radiologically contaminated USTs were filled with grout and left in place. UR warning signs were posted.

- CAS 25-02-13, Underground Storage Tank, required no further action, and no work was performed.

- CAS 25-12-01, Boiler, was clean closed by removing cadmium-insulated piping for offsite disposal as HW and a boiler for disposal as ACM. Asbestos-insulated piping was left in place for removal at a later date.

- CAS 25-23-11, Contaminated Materials, was clean closed by removing radiologically contaminated soil and a metal shed for disposal as LLW. Lead bricks, radiologically and lead-impacted soil, a concrete pump vault, a pump, and piping were removed for offsite disposal as MW.

- CAS 26-01-01, Filter Tank (RAD) and Piping, was clean closed by removing a radiologically contaminated 10,000-gal AST for disposal as LLW. Associated piping and radiologically and lead-impacted soil were removed for offsite disposal as MW.

- CAS 26-01-02, Filter Tank (RAD), was clean closed by removing a radiologically contaminated 5,000-gal AST and associated piping for disposal as LLW.

- CAS 26-02-01, Underground Storage Tank, required no further action. As a BMP, the UST was filled with grout.

- CAS 26-23-01, Contaminated Liquids Spreader, was clean closed by removing a spreader and radiologically contaminated soil for disposal as LLW. A lead shield was removed for offsite disposal as MW.

- CAS 26-99-01, Radioactively Contaminated Filters, was clean closed by removing eight radiologically contaminated filter tanks, associated piping, and a wooden shed for disposal as 
LLW. A PCB ballast was removed for offsite disposal as PCB waste, a lead brick was removed for offsite disposal as MW, a fluorescent light bulb was removed for offsite disposal as universal waste, and a hydraulic jack was removed for disposal as LLW.

\subsection{Post-Closure ReQuirements}

\subsubsection{Inspections}

Inspections are required for the following CASs:

- CAS 25-01-07, Aboveground Storage Tank

- CAS 25-02-02, Underground Storage Tank

Inspections will be performed annually to verify that UR warning signs at each CAS are in place and legible and that the UR is maintained. The interiors of the UR areas will also be inspected to confirm there have been no disturbances to the areas. Maintenance or repair needs that are identified will be scheduled within 90 working days of discovery and documented in writing at the time the work is done. Inspection results will be documented in the combined NTS post-closure annual letter report. The report will include a discussion of observations and will describe any maintenance activities performed since the last inspection. A copy of the inspection checklists will be provided, and the field notes will be maintained in the project files. A copy of the letter report will be submitted to NDEP.

\subsection{RECOMMENDATIONS}

Since closure activities for CAU 127 have been completed following the NDEP-approved CAP (NNSA/NSO, 2004b) as documented in this report, NNSA/NSO requests the following:

- A Notice of Completion be provided by NDEP to NNSA/NSO for the closure of CAU 127.

- The transfer of CAU 127 from Appendix III to Appendix IV, Closed Corrective Action Units, of the FFACO (FFACO, 1996; as amended January 2007). 
EPA, see U.S. Environmental Protection Agency.

Federal Facility Agreement and Consent Order, 1996 (as amended January 2007). Agreed to by the State of Nevada; U.S. Department of Energy, Environmental Management; U.S. Department of Defense; and U.S. Department of Energy, Legacy Management.

Federal Facility Agreement and Consent Order, 2003. Use Restriction Posting Guidance.

FFACO, see Federal Facility Agreement and Consent Order.

NNSA/NSO, see U.S. Department of Energy, National Nuclear Security Administration Nevada Site Office.

NNSA/NV, see U.S. Department of Energy, National Nuclear Security Administration Nevada Operations Office.

U.S. Department of Energy, National Nuclear Security Administration Nevada Operations Office, 2002a. Corrective Action Investigation Plan for Corrective Action Unit 127: Areas 25 and 26 Storage Tanks, Nevada Test Site, Nevada. DOE/NV--833. Las Vegas, NV.

U.S. Department of Energy, National Nuclear Security Administration Nevada Operations Office, 2002b. Nevada Environmental Restoration Project Industrial Sites Quality Assurance Project Plan, Nevada Test Site, Nevada. DOE/NV--372-REV.3. Las Vegas, NV.

U.S. Department of Energy, National Nuclear Security Administration Nevada Site Office, 2004a. Corrective Action Decision Document for Corrective Action Unit 127: Areas 25 and 26 Storage Tanks, Nevada Test Site, Nevada. DOE/NV--925-REV.1. Las Vegas, NV.

U.S. Department of Energy, National Nuclear Security Administration Nevada Site Office, 2004b. Corrective Action Plan for Corrective Action Unit 127: Areas 25 and 26 Storage Tanks, Nevada Test Site, Nevada. DOE/NV--1002. Las Vegas, NV.

U.S. Department of Energy, National Nuclear Security Administration Nevada Site Office, 2006. Streamlined Approach for Environmental Restoration Plan for Corrective Action Unit 116: Area 25 Test Cell C Facility, Nevada Test Site, Nevada. DOE/NV--1132. Las Vegas, NV.

U.S. Environmental Protection Agency, 1994. Guidance for the Data Quality Objectives Process. EPA QA/G-4. Washington D.C.

U.S. Environmental Protection Agency, 1999. Contract Laboratory Program National Functional Guidelines for Organic Data Review. EPA540/R-99/008. Washington D.C. 
CAU 127 Closure Report

Section: References

Revision: 0

Date: February 2008

THIS PAGE INTENTIONALLY LEFT BLANK 


\section{APPENDIX A*}

\section{DATA QUALITY OBJECTIVES}

As presented and published in Appendix A of the approved Corrective Action Investigation Plan for Corrective Action Unit 127: Areas 25 and 26 Storage Tanks, Nevada Test Site, Nevada, 2002, DOE/NV--833. Las Vegas, NV. 
CAU 127 Closure Report

Section: Appendix A

Revision: 0

Date: February 2008

THIS PAGE INTENTIONALLY LEFT BLANK 


\section{A.1.0 Seven-Step DQO Process for CAU 127 Investigation}

The DQO process is a strategic planning approach based on the scientific method that is used to prepare for site characterization data collection. The DQOs are designed to ensure that the data collected will provide sufficient and reliable information to identify, evaluate, and technically defend potentially viable corrective actions (i.e., no further action, close in place, or clean closure).

The CAU 127 investigation will be based on DQOs developed by representatives of the NDEP and the NNSA/NV.

Twelve CASs comprise CAU 127. Seven CASs are in Area 25, and five CASs are in Area 26. The CAS descriptions are:

- $\quad$ CAS 25-01-05, AST (100,000 gal)

- CAS 25-01-06, AST (1,000 gal)

- CAS 25-01-07, AST (1,000 gal)

- CAS 25-02-02, UST (six 10,000-gal each)

- CAS 25-02-13, UST

- CAS 25-12-01, Boiler

- CAS 25-23-11, Contaminated Materials

- CAS 26-01-01, Filter Tank (Rad) and Piping (10,000-gal tank)

- CAS 26-01-02, Filter Tank (Rad) (5,000 gal)

- CAS 26-02-01, UST (1,000 gal)

- CAS 26-23-01, Contaminated Liquids Spreader

- CAS 26-99-01, Radioactively Contaminated Filters

The investigation at all CASs will begin with Phase I activities to determine the nature of potential contamination. If a COPC is detected in any sample at concentrations above PALs, the COPC will be identified as a COC. If a COC is identified, the CAS containing that COC will undergo additional investigation during Phase II to determine the extent of contamination. Field conditions (e.g., elevated field-screening results) may warrant a Phase II investigation prior to confirmation of the presence of COCs.

\section{A.1.1 Step 1 - State the Problem}

Step 1 defines the problem that has initiated the CAU 127 investigation. This step identifies the DQO planning team members, describes the problem, and develops the CSMs. 


\section{A.1.1.1 Planning Team Members}

The DQO planning team consists of representatives from NDEP, NNSA/NV, BN, and ITLV. The primary decision-makers include NDEP and NNSA/NV representatives. Table A.1-1 lists representatives from each organization in attendance for the April 18, 2002, DQO meeting.

Table A.1-1 DQO Meeting Participants

\begin{tabular}{|c|c|}
\hline Participant & Affiliation \\
\hline \hline Tom Fitzmaurice & BN \\
\hline Michael Foley & ITLV \\
\hline John Forbes & BNLV \\
\hline John Fowler & NDEP \\
\hline Clem Goewert & ITLV \\
\hline Bridget Iverson & ITLV \\
\hline Lynn Kidman & NNSA/NV \\
\hline Sean Kosinski & ITLV \\
\hline William Nicosia & ITLV \\
\hline Kurt Schmidt & ITLV \\
\hline David Schrock & ITLV \\
\hline Robert Sobocinski & ITLV \\
\hline Thomas Thiele & BNLV \\
\hline Daniel Tobiason & \\
\hline Jeanne Wightman & ITL \\
\hline
\end{tabular}

BN - Bechtel Nevada

ITLV - IT Corporation, Las Vegas Office

NDEP - Nevada Division of Environmental Protection

NNSA/NV - DOE, National Nuclear Security Administration Nevada Operations Office

\section{A.1.1.2 Describe the Problem}

The overall problem statement for CAU 127 is: "Does sufficient information exist about the nature and extent of contamination at the 12 CASs to evaluate and select preferred corrective actions?" A preliminary assessment has indicated that existing information and data are insufficient, and a corrective action investigation is necessary. 
Corrective Action Unit 127 is being investigated because:

- The CASs are abandoned sites that were not properly closed, and may not comply with the requirements of future land use.

- Hazardous and/or radioactive constituents may be present at concentrations and locations that could potentially pose a threat to human health and the environment.

\section{A.1.1.3 Develop Conceptual Site Model}

The CSMs describe the most probable scenarios for current conditions at specific sites and define the assumptions that are the basis for identifying the appropriate sampling strategy and data collection methods. Accurate CSMs are important as they serve as the basis for all subsequent inputs and decisions throughout the DQO process.

If additional elements are identified during the investigation that are outside of the scope of the CSMs as presented in this section, the situation will be reviewed and a recommendation will be made as to how to proceed. If this occurs, NDEP will be notified and given the opportunity to comment on, or concur with, the recommendation.

An important element of a CSM is the expected fate and transport of contaminants, which infer how contaminants move through site media and where they can be expected in the environment. The expected fate and transport is based on distinguishing physical characteristics of the contaminants and media. Contaminant characteristics include solubility, density, and particle size. Media characteristics include permeability, saturation, sorting, chemical composition, and adsorption coefficients. In general, contaminants with low solubility, high sorption, and high density can be expected to be found relatively close to release points. Contaminants with high solubility, low sorption, and low density can be expected to be found further from release points.

Future land-use scenarios limit future uses of the CAU 127 CASs to various nonresidential (i.e., industrial) uses (DOE/NV, 1998). The future land-use scenarios for CAU 127 are presented in Table A.1-2. Exposure scenarios for sites located within the NTS boundaries are limited by the future land-use scenarios to site workers who may be exposed via dermal contact (adsorption), oral ingestion, or inhalation of COCs associated with soils and/or objects (e.g., tanks, concrete) due to inadvertent disturbance of these materials. An additional exposure pathway for workers is through 
external exposure to gamma radiation at sites containing potential radiological contamination (e.g., CASs associated with Test Cell C).

Table A.1-2

Future Land-Use Scenarios for CASs Within CAU 127

\begin{tabular}{|c|c|c|}
\hline CAS & Land Use Zone & Zone Description \\
\hline $\begin{array}{l}25-01-05 \\
25-02-02 \\
25-02-13 \\
25-12-01 \\
25-23-11 \\
26-01-01 \\
26-01-02 \\
26-02-01 \\
26-23-01 \\
26-99-01\end{array}$ & $\begin{array}{l}\text { Research, Test, and } \\
\text { Experiment }\end{array}$ & $\begin{array}{l}\text { Designated for small-scale research and development projects; } \\
\text { demonstrations; pilot projects; outdoor tests; and experiments for the } \\
\text { development, quality assurance, or reliability of material and equipment } \\
\text { under controlled conditions. Includes compatible defense and } \\
\text { nondefense research, development, and testing projects and activities } \\
\text { (DOE/NV, 1998). }\end{array}$ \\
\hline $\begin{array}{l}25-01-06 \\
25-01-07\end{array}$ & $\begin{array}{l}\text { Yucca Mountain Site } \\
\text { Characterization }\end{array}$ & $\begin{array}{l}\text { This area is reserved for support of the characterization of the Yucca } \\
\text { Mountain Repository. The Land Use Management Policy under a } \\
\text { Memorandum of Agreement with the NTS gives the Yucca Mountain } \\
\text { Project technical responsibility independent of, but in coordination with } \\
\text { the agreement (DOE, 2002). }\end{array}$ \\
\hline
\end{tabular}

\section{A.1.1.3.1 Conceptual Site Models for CAU 127}

Two CSMs have been developed for CAU 127 using historical background information, knowledge from studies at similar sites, and data from previous sampling efforts. The CSMs are termed Aboveground Tank/Piping (CSM\#1) and Underground Tank/Piping/Structure (CSM\#2). The applicability of the CSMs to each CAS is summarized in Table A.1-3. As shown in Table A.1-3, both CSMs apply to several of the CAU 127 CASs.

Table A.1-3

\section{CSMs and Associated CASs}

\begin{tabular}{|c|c|c|c|c|c|c|c|c|c|c|c|c|}
\hline $\begin{array}{l}\text { Conceptual Site Model } \\
\text { (CSM) }\end{array}$ & 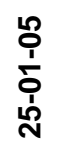 & $\begin{array}{l}\text { ণे } \\
\text { N̦ } \\
\text { ஸे }\end{array}$ & 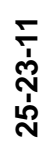 & $\begin{array}{l}\bar{d} \\
\text { N̦} \\
\text { ஸे }\end{array}$ & 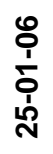 & 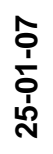 & $\begin{array}{l}\text { m. } \\
\text { ণั } \\
\text { ஸे }\end{array}$ & 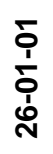 & 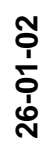 & $\begin{array}{l}\text { 'o } \\
\text { ờ } \\
\text { ஸे }\end{array}$ & $\begin{array}{l}\bar{d} \\
\text { ฟิ } \\
\text { ஸे }\end{array}$ & $\begin{array}{l}\text { o } \\
\text { ஸे } \\
\text { ஸे }\end{array}$ \\
\hline Aboveground Tank/Piping & $x$ & $x$ & $\mathrm{x}$ & $x$ & $x$ & $x$ & $x$ & $x$ & $x$ & $x$ & & $x$ \\
\hline $\begin{array}{c}\text { Underground } \\
\text { Tank/Piping/Structure }\end{array}$ & $x$ & $x$ & $x$ & & & & $x$ & $x$ & $x$ & & $X$ & \\
\hline
\end{tabular}

$X$ - The CSM applies to this CAS. 


\section{Aboveground Tank/Piping Conceptual Site Model (CSM \#1)}

Eleven CASs are included in the Aboveground Tank/Piping CSM developed for CAU 127 (Table A.1-3). Figure A.1-1 shows a generalized representation of CSM\#1. Tanks or other containment vessels have been used at all but one of the CASs within this CAU. If a spill or surface release occurred at one of these sites, the liquid containing COPCs would likely seep into the ground. Lateral migration is possible on the ground surface; however, in subsurface soils, contaminants would be expected to migrate primarily downward, and to a lesser degree horizontally. Concrete or a hardpan layer (i.e., caliche), if present, would limit vertical migration of contaminants or would modify the location, if any, where vertical migration could occur. In the case of a concrete pad, liquid contaminants would have a proclivity to run off, if the concrete was sloped, or would migrate through cracks into the subsurface. Precipitation could accelerate contaminant migration laterally as runoff and vertically as percolation. However, percolation should be limited, due to low precipitation rates and high evapotranspiration rates. This CSM predicts that the concentration of the contaminants would be highest in the immediate vicinity of a release (at the ground surface), and would decrease with distance, both horizontally and vertically. However, due to volatilization and/or weathering, the level of contamination may actually increase with depth in the near-surface soils (less than 6 in. bgs). Since vertical migration is expected to be limited, it is unlikely that any contamination would reach groundwater.

At CASs with insulated aboveground piping, ACM may be present, and the potential exists for friable asbestos. If friable asbestos is present, the asbestos could become airborne. The CASs with observed ACM or the potential for ACM are 25-01-05, 25-02-02, 25-23-11, 25-12-01, 26-01-01, 26-01-02, and 26-99-01.

\section{Underground Tank/Piping/Structure conceptual Site Model (CSM \#2)}

Seven CAU 127 CASs are included in the Underground Tank/Piping/Structure CSM (Table A.1-3). Figure A.1-2 shows a generalized representation of CSM\#2. This CSM is similar to CSM\#1 except that lateral migration of contaminants in runoff is not a transport mechanism for CSM\#2.

If a release or leak from an underground structure occurred, the liquid containing COPCs would migrate away from the release point, primarily downward, and to a lesser degree horizontally. Capillary action may cause some secondary migration upward, but this would be minimal. Migration 


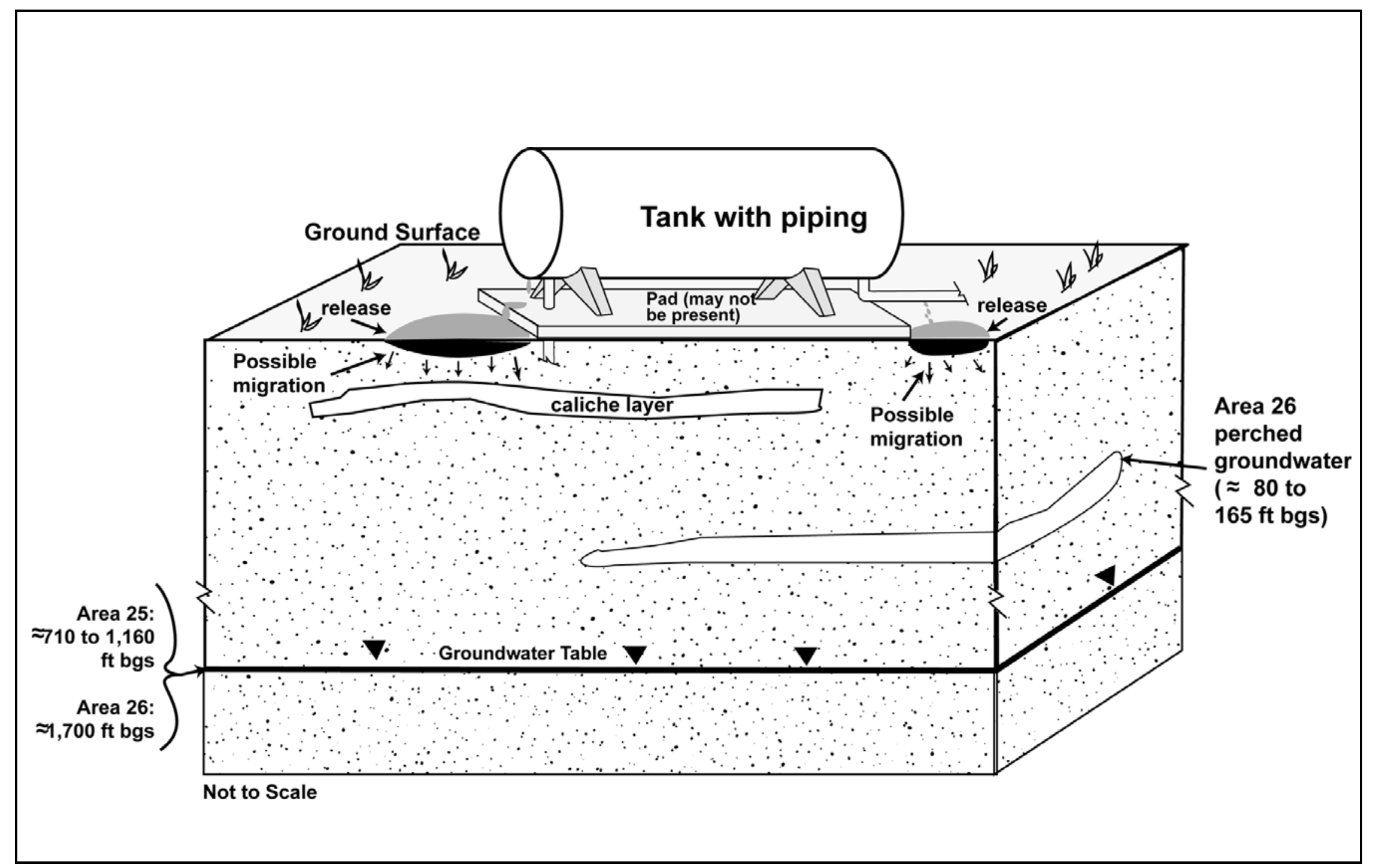

Figure A.1-1

Aboveground Tank/Piping Conceptual Site Model (CSM \#1) 


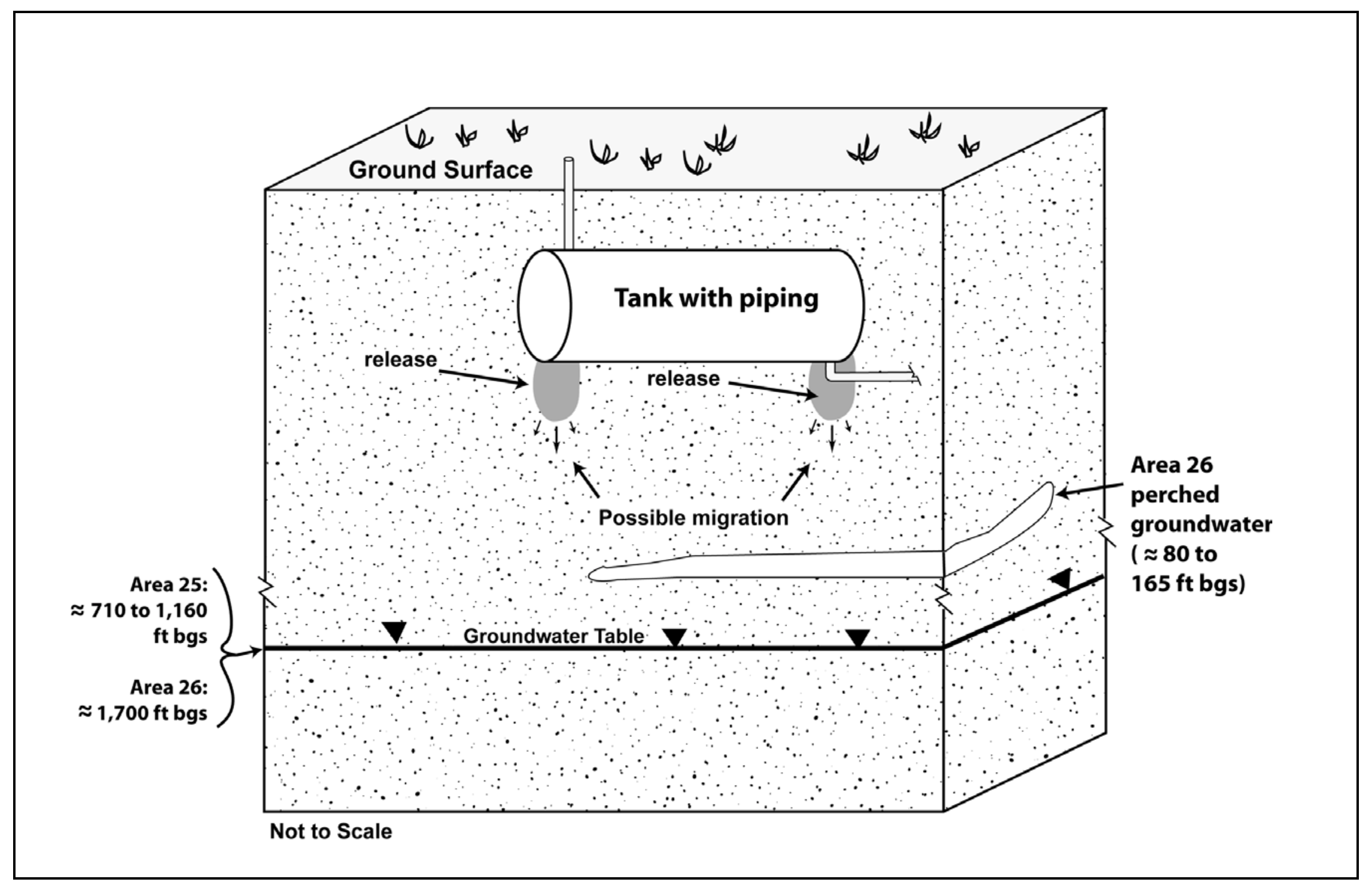

Figure A.1-2

Underground Tank/Piping/Structure Conceptual Site Model (CSM \#21) 
is predicted to be similar to the subsurface migration discussed in CSM \#1. This CSM predicts that the concentration of contaminants would be highest in the immediate vicinity of a subsurface release location, and would decrease with distance, both horizontally and vertically.

The following sections provide additional information on elements of the CSMs.

\section{Affected Media}

For CSM \#1, Aboveground Tank/Piping, the potentially affected media are surface and subsurface soils. Where ACMs are present, the air may contain asbestos if the materials are disturbed. For CSM \#2, Underground Tank/Piping/Structure, the potentially affected medium is subsurface soil.

Any contamination found at these CASs would be attributable to direct release to the surface or subsurface. Insufficient records are available for many of these areas; therefore, much of the information related to COPCs is based upon limited historical information, interviews with current/former site employees, and site visits performed during preliminary assessments of the CASs.

\section{Location of Contamination/Release}

Where at- or above-grade features are present (CSM \#1), contamination may be found in surface soils, as well as subsurface soils. Where the features are below-grade (CSM \#2), surface soil contamination is not expected. Migration of contamination for both CSMs would be expected to be primarily downward, with horizontal migration to a lesser extent. For both CSMs, the presence of relatively impermeable layers (e.g., concrete, bedrock, or caliche) may influence both lateral and vertical migration.

\section{Transport Mechanisms}

The degree of contaminant migration at these sites is unknown, but it is assumed to be minimal based on low precipitation and high evapotranspiration rates. Runoff could cause lateral migration of contaminants over the ground surface for CSM \#1. Contaminants may also have been transported by infiltration and percolation of precipitation through soil, which would serve as a driving force for downward migration. See "Lateral and Vertical Extent of Contamination" for additional information. Friable asbestos could become airborne, and transported by wind to become an air and surface soil contaminant. 


\section{Preferential Pathways}

Preferential pathways for contaminant migration are not expected for the CAU 127 CASs. As discussed previously, the presence of relatively impermeable layers could modify transport pathways both on the ground surface (e.g., concrete pads) and in the subsurface (e.g., caliche layers). The potential effect of these layers will be considered in the development of sampling schemes and sampling contingencies discussed in the CAIP.

\section{Lateral and Vertical Extent of Contamination}

Contamination, if present, is expected to be generally confined to the site. However, where multiple sites are adjacent, migration from one site may have impacted the immediately adjacent site. For example, the piping for the CAS 26-01-01 tank ends at the filter tank shed (CAS 26-99-01). Lateral migration from one CAS may have contaminated the soil below the adjacent CAS in such a situation. It is expected that lateral contamination will be confined to the CAS and adjacent CAS, if applicable. However, the potential exists for surface soil contamination due to a source unrelated to the CAS under investigation. This may be the case for the CASs located at Test Cell C, where widespread radiological contamination of the ground surface may be present.

Surface migration may occur as a result of a spill or leak and subsequently as runoff of precipitation. Surface migration is a biasing factor considered in the selection of sampling points.

Downward contaminant transport is expected to be very limited due to low precipitation and high evapotranspiration rates. Average annual precipitation is only 3 to 6 in. on valleys and less than $10 \mathrm{in.} \mathrm{on} \mathrm{ridges} \mathrm{and} \mathrm{mesas} \mathrm{in} \mathrm{this} \mathrm{region} \mathrm{(USGS,} \mathrm{1975),} \mathrm{while} \mathrm{the} \mathrm{potential} \mathrm{evaporation} \mathrm{rate} \mathrm{is} \mathrm{almost}$ 66 in. per year (DOE, 2002). Subsurface migration will be influenced by the geophysical properties of the soil, such as permeability, porosity, and conductivity. The presence of a hardpan layer (i.e., caliche) could limit vertical migration of contaminants and enhance lateral migration in some cases. The vertical migration of contaminants is expected to be limited due to the lack of a driving force (minimal infiltration). Migration of certain constituents (i.e., metals, radionuclides) will also be controlled to varying degrees by geochemical processes, such as adsorption, ion exchange, and precipitation of solids from solution. 
Groundwater contamination is not considered a likely scenario at CAU 127. The groundwater depth varies between areas from approximately 2,390 to 2,470 ft above mean sea level (amsl) (approximately 710 to $1,040 \mathrm{ft}$ bgs) in Area 25 (USGS, 1995) to approximately 2,700 ft amsl $(1,700 \mathrm{ft}$ bgs) in Area 26 (DRI, 1988). A perched water table is present throughout most of Area 26 at depths ranging from approximately 80 to165 ft bgs (USGS, 1964). Additional perched groundwater lenses may exist between the known perched water table and the regional water table.

Contaminant transport by the downward movement of precipitation through the unsaturated zone is not a viable transport mechanism for CAS 25-02-13 at the X-Tunnel. X-Tunnel is located on the southwest flank of Little Skull Mountain at an elevation of approximately 3,540 ft amsl. The unsaturated zone is therefore over 1,000-ft thick at X-Tunnel. Also, no water drainage is reported at $\mathrm{X}$-Tunnel, implying that X-Tunnel does not intersect any water-transmitting faults or fractures, or perched water-bearing units.

\section{A.1.1.3.2 Contaminants of Potential Concern}

The CAS-specific list of COPCs was developed based upon process knowledge of the CASs, review of historic documents, past investigations at related CASs, and interviews with former site employees. The COPCs based on existing information are summarized below, with supporting information about how the COPCs were developed for each CAS. Due to uncertainty regarding the existing COPC information, additional constituents have been included as COPCs for the investigation of CAU 127. These COPCs are listed in Section A.1.3.3.

\section{CAS 25-01-05-Aboveground Storage Tank; 25-02-02-Underground Storage Tank(s);} 25-23-11-Contaminated Materials: These CASs are part of the WWTS at Test Cell C that was used for the NF-1 test series in 1972. The 100,000-gallon tank was used as back-up to the six 10,000-gallon USTs to store water generated during this series of tests. The water was processed through two filter tanks, which were previously removed, and then discharged to an on-site leachfield. Corrective Action Site 25-23-11 consists of a concrete vault, heat shield, pump, and piping. Historical documentation reports the use of VOCs during previous site remediation activities. Based upon historical information, the COPCs for these three CASs are VOCs, RCRA metals, asbestos (on piping), gamma-emitting radionuclides, Sr-90, plutonium, tritium, and uranium. 
Analytical results from previous investigations at the WWTS indicate the presence of Cs-137, Sr-90, U-235, Eu-155, Cd-109, and Sb-125.

CAS 25-12-01-Boiler: This boiler is adjacent to the Test Cell $\mathrm{C}$ pumphouse building. The boiler was part of a borated water system that was used as a radiation shield. The boiler ran on propane. According to historical documents, the COPCs are radioisotopes that may have been present (through activation) in the boiler water (Cl-36, Co-60, Eu-154, Eu-155, and K-40). Potential asbestos pipe coverings are also present.

CAS 25-01-06-Aboveground Storage Tank; CAS 25-01-07-Aboveground Storage Tank: These CASs were installed in 1965 and originally contained diesel fuel used to refuel locomotives at the ETSM Building 3901 within the E-MAD Facility. After 1986, these tanks were used to supply fuel to heat the Building 3901. Visible petroleum staining on the ground at the north end of each tank was observed during a site visit conducted as part of the preliminary assessment of the CASs. The COPCs are petroleum hydrocarbons, specifically, diesel and heating oil.

There is a concern that radiological contamination may be present in the soil at this site, although this contamination is not a result of activities at these CASs. Therefore, radiological constituents will be added to the list of analytes.

CAS 25-02-13-Underground Storage Tank: This CAS is located in the X-Tunnel and is the previous location of an underground tank. The tank and gravel from the tank location were removed from the X-Tunnel experiment chamber in June 1996. The site was used by the U.S. Army, sometime between 1985 and 1987, as a catch basin to collect and contain hydraulic fluid from the firing table of a classified project. According to a radiological report for the X-Tunnel, depleted uranium (DU) was used in the tunnel prior to removal of the tank; therefore, it may also be a COPC (Bastian, 1996). The tank was reported to have been left in place until the X-Tunnel remediation was nearly completed, in order to catch any runoff generated during the process. The COPCs for this CAS are DU and hydraulic fluid (petroleum hydrocarbons).

CAS 26-01-01-Filter Tank (RAD) and Piping; CAS 26-01-02-Filter Tank (RAD); CAS 26-99-01-Radioactively Contaminated Filters: These CASs comprised a filter system that may have been used as part of a thin film evaporator system at the Project Pluto Disassembly Facility. 
This system may have been used to recover and solidify radioactive wastes from liquid decontamination streams. Based upon a preliminary assessment of the filter system, the COPCs are beryllium, lead, uranium, RCRA metals, PCBs, petroleum hydrocarbons (gasoline and oil), Am-241, $\mathrm{Pu}-238, \mathrm{Pu}-239 / 240$, and asbestos.

CAS 26-02-01-Underground Storage Tank: This CAS was a water supply tank at the Project Pluto Check Station. It is unknown how long the tank was used or if it was used for any other purpose. As there is no information regarding any other use, there are no COPCs identified for this CAS.

CAS 26-23-01-Contaminated Liquids Spreader: The spreader was used to spray liquid intentionally contaminated with short-lived radionuclides throughout the associated exercise area at the Port Gaston Training Area. Two exercises were conducted, one in 1981 and the other in 1983, in which the liquids spreader was used to spray radiologically contaminated water to simulate a nuclear weapon accident. Materials reported to have been used were Ra-223 and Hg-197 in 1981, and Ra-223 and Pd-103 in 1983. Due to their short half-lives, these constituents are not COPCs. However, additional radiological constituents may have been present as impurities in the material used. The COPCs expected to be present include Ra-226, Ac-227, and Th-227. Other impurities may also be present.

\section{A.1.2 Step 2 - Identify the Decision}

This step develops the Phase I and Phase II decision statements and defines alternative actions.

\section{A.1.2.1 Develop Decision Statement}

Two decision statements are required for this investigation. The decision statement for Phase I of the investigation is: "Determine if a COC is present." The decision statement for Phase II is:

"Determine the lateral and vertical extent of a COC."

\section{A.1.2.2 Alternative Actions to the Decisions}

If a COC is not present, further assessment of the CAS is not required. If a COC is present and its extent is defined in both the lateral and vertical directions, further assessment of the CAS is not required. If extent is not defined, reevaluate site conditions and collect additional samples. 


\section{A.1.3 Step 3 - Identify the Inputs to the Decision}

This step identifies the information needed, determines sources for information, determines the basis for establishing the action level, and identifies sampling and analysis methods that can meet the data requirements. To determine if a COC is present, each sample result is compared to the PAL (Section A.1.3.2). If any sample result is greater than the PAL, then the applicable CAS is advanced to a Phase II investigation for that analyte. This approach does not use a statistical mean/average for comparison to the PAL, but rather the individual result, to identify COCs.

\section{A.1.3.1 Information Needs and Information Sources}

In order to determine if a COC is present at a particular CAS, sample data must be collected and analyzed following these two criteria: (1) samples must be collected in areas most likely to contain a COC and (2) the analytical suite selected must be sufficient to detect any COCs present in the samples.

Biasing factors to support these criteria include:

- Documented process knowledge on source and location of release

- Field observations

- Field screening

- Radiological surveys

- Historical sample results

- Experience and data from investigations of similar sites

- Professional judgement

In order to determine the extent of a COC, samples must be collected at locations to bound the lateral and vertical extent of COCs. The data required to satisfy the information need for each COC is a sample result that is below the PAL. Three lateral step-out samples and one vertical sample will be collected around and/or below each CAS identified as having exceeded the PAL for one or more COCs. The lateral samples will be located a maximum of $15 \mathrm{ft}$ from the previous location, while the vertical samples will begin $2 \mathrm{ft}$ below the previous location depth with COCs. The lateral step-out distance will generally be based upon the size of the already determined contaminated area. The step-outs for small areas will be just a few feet from the previous contaminated locations, whereas on large contaminated areas, the step-outs will increase to as much as $15 \mathrm{ft}$. When indicators or biasing factors indicate that the COC concentration at the step-out location may still exceed the PAL, then an 
additional step-out distance may be used to collect the analytical sample. If the location where the PAL is exceeded is surrounded by clean locations, then lateral step-outs may not be necessary. In that case, sampling may consist only of sampling from deeper intervals at or near the original location to determine the vertical extent of contamination. Step-out locations may be moved due to access or safety issues; however, the modified locations must meet the decision needs and criteria for Phase II decisions.

Phase II samples will only be analyzed for those parameters that exceeded PALs (i.e., COCs) in Phase I samples. Biasing factors to support selection of Phase II sampling locations may include:

- Geophysical and/or radiological surveys

- Documented process knowledge on source and location of release

- Field observations

- Field-screening results

- Historical sample results

- Experience and data from investigations of similar sites

- Professional judgement

- Previous sample results

Table A.1-4 (Phase I) and Table A.1-5 (Phase II) lists the information needs, the source of information for each need, and the proposed methods to collect the data. The last column addresses the QA/QC data type and associated metric. The data type is determined by the intended use of the resulting data in decision making. Data types are discussed in the following text.

\section{Quantitative Data}

Quantitative data measure the quantity or amount of a characteristic or component within the population of interest. These data require the highest level of QA/QC in collection and measurement systems because the intended use of the data is to resolve primary decisions (i.e., rejecting or accepting the null hypothesis) and/or verifying closure standards have been met. Laboratory analytical data are generally considered quantitative.

\section{Semiquantitative Data}

Semiquantitative data indirectly measure the quantity or amount of a characteristic or component. Inferences are drawn about the quantity or amount of a characteristic or component because a correlation has been shown to exist between the indirect measurement and the results from a 
Table A.1-4

Information Needs to Resolve the Phase I Decision

(Page 1 of 2)

\begin{tabular}{|c|c|c|c|c|}
\hline $\begin{array}{l}\text { Information } \\
\text { Need }\end{array}$ & $\begin{array}{l}\text { Information } \\
\text { Source }\end{array}$ & Collection Method & $\begin{array}{l}\text { Biasing Factors to } \\
\text { Consider }\end{array}$ & Data Type/Metric \\
\hline \multicolumn{5}{|c|}{$\begin{array}{l}\text { Decision: Determine if a COC is present. } \\
\text { Criteria 1: Samples will be collected in areas most likely to contain a COC. }\end{array}$} \\
\hline \multirow{6}{*}{$\begin{array}{l}\text { Source and } \\
\text { location of } \\
\text { release } \\
\text { points }\end{array}$} & $\begin{array}{c}\text { Process } \\
\text { knowledge } \\
\text { compiled during } \\
\text { the Preliminary } \\
\text { Assessment } \\
\text { process and } \\
\text { previous } \\
\text { investigations of } \\
\text { similar sites }\end{array}$ & $\begin{array}{l}\text { Information documented in } \\
\text { CSM and public reports - } \\
\text { no additional data needed }\end{array}$ & None & $\begin{array}{c}\text { Qualitative - CSM has } \\
\text { not been shown to be } \\
\text { inaccurate }\end{array}$ \\
\hline & $\begin{array}{l}\text { Site visit and } \\
\text { field } \\
\text { observations }\end{array}$ & $\begin{array}{l}\text { Conduct site visits and } \\
\text { document field } \\
\text { observations }\end{array}$ & $\begin{array}{c}\text { View caps, joints, } \\
\text { connections of pipes, } \\
\text { tanks, etc. and surface } \\
\text { soil for potential leaks, } \\
\text { spills }\end{array}$ & $\begin{array}{c}\text { Qualitative - CSM has } \\
\text { not been shown to be } \\
\text { inaccurate }\end{array}$ \\
\hline & $\begin{array}{l}\text { Radiological } \\
\text { surveys }\end{array}$ & $\begin{array}{l}\text { Perform radiological } \\
\text { surveys using appropriate } \\
\text { methods }\end{array}$ & $\begin{array}{l}\text { Bias locations based } \\
\text { upon areas of visible } \\
\text { or likely surface } \\
\text { spills/leaks }\end{array}$ & $\begin{array}{l}\text { Semiquantitative - } \\
\text { Locations based on } \\
\text { biasing criteria } \\
\text { stipulated in DQO } \\
\text { Step } 7\end{array}$ \\
\hline & Field screening & $\begin{array}{l}\text { Collect soil samples from } \\
\text { stained areas, or areas of } \\
\text { likely spills/leaks }\end{array}$ & $\begin{array}{l}\text { Bias locations based } \\
\text { upon results of } \\
\text { process info and field } \\
\text { observations }\end{array}$ & $\begin{array}{l}\text { Semiquantitative- } \\
\text { Sampling locations } \\
\text { based on visual or } \\
\text { process knowledge }\end{array}$ \\
\hline & $\begin{array}{l}\text { Biased } \\
\text { samples }\end{array}$ & $\begin{array}{l}\text { Generate sampling points } \\
\text { based on results of } \\
\text { radiological surveys and } \\
\text { field screening }\end{array}$ & $\begin{array}{c}\text { Send samples with } \\
\text { highest } \\
\text { survey/screening } \\
\text { results to laboratory }\end{array}$ & $\begin{array}{l}\text { Semiquantitative - } \\
\text { Sampling based on } \\
\text { survey and screening } \\
\text { results. }\end{array}$ \\
\hline & Biased samples & $\begin{array}{l}\text { Additional points will be } \\
\text { located near CAS features }\end{array}$ & $\begin{array}{l}\text { Bias locations } \\
\text { along/around features. }\end{array}$ & $\begin{array}{l}\text { Semiquantitative - } \\
\text { Sampling based on } \\
\text { CAS features. }\end{array}$ \\
\hline \multicolumn{5}{|c|}{$\begin{array}{l}\text { Decision: Determine if a COC is present. } \\
\text { Criteria 2: Analyses must be sufficient to detect any COCs in samples above action limits. }\end{array}$} \\
\hline $\begin{array}{l}\text { Identification } \\
\text { of all } \\
\text { potential } \\
\text { contaminants }\end{array}$ & $\begin{array}{c}\text { Process } \\
\text { knowledge } \\
\text { compiled during } \\
\text { PA process and } \\
\text { previous } \\
\text { investigations of } \\
\text { similar sites }\end{array}$ & $\begin{array}{l}\text { Information documented in } \\
\text { CSM and public reports - } \\
\text { no additional data needed }\end{array}$ & None & $\begin{array}{c}\text { Qualitative - CSM has } \\
\text { not been shown to be } \\
\text { inaccurate }\end{array}$ \\
\hline
\end{tabular}


Table A.1-4

Information Needs to Resolve the Phase I Decision

(Page 2 of 2)

\begin{tabular}{|c|c|c|c|c|}
\hline $\begin{array}{l}\text { Information } \\
\text { Need }\end{array}$ & $\begin{array}{l}\text { Information } \\
\text { Source }\end{array}$ & Collection Method & $\begin{array}{l}\text { Biasing Factors to } \\
\text { Consider }\end{array}$ & Data Type/Metric \\
\hline \multicolumn{5}{|c|}{$\begin{array}{l}\text { Decision: Determine if a COC is present. } \\
\text { Criteria 2: Analyses must be sufficient to detect any COCs in samples above action limits. }\end{array}$} \\
\hline $\begin{array}{l}\text { Analytical } \\
\text { results }\end{array}$ & $\begin{array}{c}\text { Data packages } \\
\text { of biased } \\
\text { samples }\end{array}$ & $\begin{array}{l}\text { Appropriate sampling } \\
\text { techniques and approved } \\
\text { analytical methods will be } \\
\text { used. MDLs and MDAs } \\
\text { are sufficient to provide } \\
\text { quantitative results for } \\
\text { comparison to PALs }\end{array}$ & None & $\begin{array}{c}\text { Quantitative - Validated } \\
\text { analytical results will be } \\
\text { compared to PALs }\end{array}$ \\
\hline \multicolumn{5}{|c|}{$\begin{array}{l}\text { Decision: Determine if sufficient information exists to characterize waste. } \\
\text { Criteria: Analyses must be sufficient to allow disposal options to be accurately identified and estimated. }\end{array}$} \\
\hline $\begin{array}{c}\text { Radiological } \\
\text { data for } \\
\text { comparison } \\
\text { to Free } \\
\text { Release } \\
\text { Criteria }\end{array}$ & $\begin{array}{l}\text { Radiological } \\
\text { surveys }\end{array}$ & $\begin{array}{c}\text { Perform radiological } \\
\text { surveys using appropriate } \\
\text { methods }\end{array}$ & $\begin{array}{l}\text { Bias locations based } \\
\text { upon areas of visible } \\
\text { or likely surface } \\
\text { spills/leaks. Areas of } \\
\text { accumulation }\end{array}$ & $\begin{array}{l}\text { Semiquantitative - } \\
\text { Locations based on } \\
\text { biasing criteria } \\
\text { stipulated in DQO } \\
\text { Step } 7\end{array}$ \\
\hline $\begin{array}{l}\text { Analytical } \\
\text { results }\end{array}$ & $\begin{array}{l}\text { Data packages } \\
\text { of tank content } \\
\text { samples }\end{array}$ & $\begin{array}{c}\text { Appropriate sampling } \\
\text { techniques and approved } \\
\text { analytical methods will be } \\
\text { used. MDLs and MDAs } \\
\text { are sufficient to provide } \\
\text { quantitative results for } \\
\text { comparison to disposal } \\
\text { requirements }\end{array}$ & $\begin{array}{c}\text { Sufficient material } \\
\text { must be available for } \\
\text { analysis }\end{array}$ & $\begin{array}{l}\text { Quantitative - Validated } \\
\text { analytical results will be } \\
\text { compared to disposal } \\
\text { criteria }\end{array}$ \\
\hline
\end{tabular}

quantitative measurement. The $\mathrm{QA} / \mathrm{QC}$ requirements on semiquantitative collection and measurement systems are high but may not be as rigorous as a quantitative measurement system. Semiquantitative data contribute to decision making but are not used alone to resolve primary decisions. Field-screening data are generally considered semiquantitative. The data are often used to guide investigations toward quantitative data collection.

\section{Qualitative Data}

Qualitative data identify or describe the characteristics or components of the population of interest. The QA/QC requirements are the least rigorous on data collection methods and measurement systems. The intended use of the data is for information purposes, to refine conceptual models, and 
Table A.1-5

Information Needs to Resolve the Phase II Decision

\begin{tabular}{||l|l|l|l||}
\hline \multicolumn{1}{|c|}{ Information Need } & \multicolumn{1}{|c|}{ Information Source } & \multicolumn{1}{c|}{ Collection Method } & \multicolumn{1}{c|}{ Data Type/Metric } \\
\hline \hline \multicolumn{4}{|c|}{ Decision: Determine the extent of a COC } \\
\hline $\begin{array}{l}\text { Identification of Applicable } \\
\text { Contaminants }\end{array}$ & Sample data packages & $\begin{array}{l}\text { Review analytical results to } \\
\text { select COCs. }\end{array}$ & $\begin{array}{l}\text { Quantitative - Only COCs } \\
\text { identified will be analyzed } \\
\text { in subsequent samples. }\end{array}$ \\
\hline \multirow{3}{*}{ Extent of Contamination } & Field observations & $\begin{array}{l}\text { Document field } \\
\text { observations. }\end{array}$ & $\begin{array}{l}\text { Qualitative - CSM has not } \\
\text { been shown to be } \\
\text { inaccurate. }\end{array}$ \\
\cline { 2 - 5 } & Field-screening results & $\begin{array}{l}\text { Conduct field screening } \\
\text { with appropriate } \\
\text { instrumentation. }\end{array}$ & $\begin{array}{l}\text { Semiquantitative - FSRs } \\
\text { will be compared to FSLs. }\end{array}$ \\
\cline { 2 - 5 } & Analytical results & $\begin{array}{l}\text { Appropriate sampling } \\
\text { techniques and approved } \\
\text { analytical methods will be } \\
\text { used to bound COCs. }\end{array}$ & $\begin{array}{l}\text { Quantitative - Validated } \\
\text { analytical results will be } \\
\text { compared to PALs to } \\
\text { determine COC extent. }\end{array}$ \\
\hline
\end{tabular}

guide investigations rather than resolve primary decisions. This measurement of quality is typically assigned to historical information and data where QA/QC may be highly variable or not known. Professional judgement is often used to generate qualitative data.

Metrics provide a tool to determine if the collected data support decision making as intended. Metrics tend to be numerical for quantitative and semiquantitative data, and descriptive for qualitative data.

\section{A.1.3.2 Determine the Basis for the Preliminary Action Levels}

Site workers may be exposed to contaminants through oral ingestion, inhalation, or dermal contact (absorption) of soil during disturbance of this medium. Laboratory analytical results for soils will be compared to the following PALs to evaluate if COPCs are present at levels that may pose an unacceptable risk to human health and/or the environment:

- EPA Region 9 Risk-Based Preliminary Remediation Goals for Industrial Soils (EPA, 2002).

- Background concentrations for metals when natural background exceeds the PRG, as is often the case with arsenic. Background is considered the mean plus two times the standard deviation of the mean for sediment samples collected by the Nevada Bureau of Mines and Geology throughout the Nellis Air Force Range (NBMG, 1998; Moore, 1999). 
- $\mathrm{TPH}$ action limit of $100 \mathrm{mg} / \mathrm{kg}$, per the NAC 445A.2272 (NAC, 2002).

- The PALs for radionuclides are isotope-specific and defined as the maximum concentration for that isotope found in samples from undisturbed background locations in the vicinity of the NTS (McArthur and Miller, 1989; US Ecology Atlan-Tech, 1992; DOE/NV, 1996).

Solid media such as concrete and/or structures may only pose a potential radiological exposure risk to site workers. Surface radiological surveys of the solid media will be compared to the free-release criteria, as defined in the NV/YMP Radiological Control Manual (DOE/NV, 2000), to evaluate if COPCs are present at levels that may pose an unacceptable risk to human health and/or the environment.

\section{A.1.3.3 Potential Sampling Techniques and Appropriate Analytical Methods}

\section{Radiological Surveys}

Radiological surveys will be used to determine presence/lateral extent of contamination. Radiological surveys will follow standard procedures. Further information is provided in Section A.1.7.1.

\section{Sampling}

Augering, direct-push, excavation, drilling, or other appropriate sampling methods will be used to collect soil samples. Sample collection and handling activities will follow standard procedures. The Industrial Sites QAPP (DOE/NV, 2002), unless otherwise stipulated in the CAIP, provides analytical methods and laboratory requirements (e.g., detection limits, precision, and accuracy). Sample volumes are laboratory- and method-specific and will be determined in accordance with laboratory requirements.

At all CASs within CAU 127, both site characterization and waste characterization efforts are proposed. Site characterization sampling and analysis are the focus of the DQO process. However, waste characterization sampling and analysis has been addressed to support the decision-making process for waste management, and also to ensure an efficient field program.

Samples of tank contents, filter medium, or other material may be collected, as appropriate, and submitted for analysis. These samples will assist in profiling media for waste characterization 
purposes. Solid media (e.g., concrete or tank walls) will not be analyzed by a laboratory for chemical or radiological parameters. Specific analyses required for the disposal of IDW are identified in Section 5.0 of the CAIP.

\section{Analytical Program}

To ensure that laboratory analyses are sufficient to detect contamination in samples at concentrations exceeding the MRL, Phase I chemical and/or radiological parameters of interest have been selected for each CAS. The parameters for each CAS are identified in Table A.1-6. The Phase I analytical program was developed based on the historical COPC information presented in Section A.1.1.3.2. The analytical program also includes other constituents that have been added as COPCs due to uncertainty in existing documentation for the CASs. Analytical methods are specified in the Industrial Sites QAPP (DOE/NV, 2002), unless superseded by the CAIP.

The analytes of interest for the investigation of PCBs, are listed in Table A.1-7. The SVOC and VOC compounds expected to be analyzed for the investigation are included in Table A.1-8 and Table A.1-9, respectively.

Only those COCs identified during Phase I sampling will be analyzed during Phase II, provided that the Phase I analytical results are available. If Phase I results are not available, Phase II samples will be analyzed for all the parameters listed in Table A.1-6 for a given CAS.

\section{A.1.4 Step 4 - Define the Boundaries of the Study}

The purpose of this step is to define the target population of interest, specify the spatial and temporal features of the population that are pertinent for decision making, determine practical constraints on data collection, and define the scale of decision making relevant to target populations.

\section{A.1.4.1 Define the Target Population}

The target populations are dependent upon the CSM(s) applicable to the CAS. Phase I sampling target populations are identified in Table A.1-10. These target populations represent locations within the CAS that will contain COCs, if present. If it is determined to be necessary to sample additional target populations, they may also be sampled during Phase I of the investigation. While the 
Table A.1-6

Analytical Program

(Includes Site and Waste Characterization Analyses)

\begin{tabular}{|c|c|c|c|c|c|c|c|c|c|c|c|c|}
\hline Analyses $^{a}$ & $\begin{array}{l}\text { L } \\
\stackrel{1}{0} \\
\text { ஸे } \\
\text { ஸे }\end{array}$ & 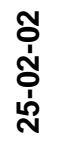 & $\begin{array}{l}\text { Г̄ } \\
\text { ஸे } \\
\text { ஸे }\end{array}$ & $\begin{array}{l}\bar{\vdots} \\
\text { ஸे } \\
\text { م่ }\end{array}$ & 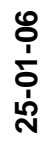 & 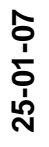 & $\begin{array}{l}\text { m. } \\
\text { ণิ } \\
\text { ஸे }\end{array}$ & $\begin{array}{l}\text { o } \\
\frac{1}{0} \\
\text { ஸे }\end{array}$ & $\begin{array}{l}\text { ํ } \\
1 \\
\text { ó } \\
\grave{d}\end{array}$ & 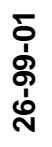 & $\begin{array}{l}\bar{\vdots} \\
\text { ญे } \\
\text { ஸे }\end{array}$ & 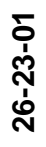 \\
\hline \multicolumn{13}{|c|}{ Organics } \\
\hline $\begin{array}{l}\text { TPH (Diesel- and Gasoline- Range } \\
\text { Organics, unless specified) }\end{array}$ & $\bullet$ & $\bullet$ & $\bullet$ & $\bullet$ & $\bullet$ & $\bullet$ & $\bullet$ & $\bullet b$ & $\bullet^{\mathrm{b}}$ & $\bullet^{b}$ & $\bullet$ & $\bullet$ \\
\hline PCBs & $\bullet$ & $\bullet$ & $\bullet$ & $\bullet$ & $\bullet$ & $\bullet$ & & $\bullet$ & $\bullet$ & $\bullet$ & $\bullet$ & $\bullet$ \\
\hline SVOCs & $\bullet$ & $\bullet$ & $\bullet$ & $\bullet$ & $\bullet$ & $\bullet$ & & $\bullet$ & $\bullet$ & $\bullet$ & $\bullet$ & $\bullet$ \\
\hline VOCs & $\bullet$ & $\bullet$ & $\bullet$ & $\bullet$ & $\bullet$ & $\bullet$ & & $\bullet$ & $\bullet$ & $\bullet$ & $\bullet$ & $\bullet$ \\
\hline \multicolumn{13}{|c|}{ Metals } \\
\hline Total Beryllium & $\bullet$ & $\bullet$ & $\bullet$ & $\bullet$ & & & & $\bullet$ & $\bullet$ & $\bullet$ & $\bullet$ & $\bullet$ \\
\hline \multicolumn{13}{|l|}{ Total Boron } \\
\hline Asbestos & $\bullet$ & $\bullet$ & $\bullet$ & $\bullet$ & & & & $\bullet$ & $\bullet$ & $\bullet$ & & \\
\hline \multicolumn{13}{|c|}{ Radionuclides } \\
\hline Gamma Spectrometry & $\bullet$ & $\bullet$ & $\bullet$ & $\bullet$ & $\bullet$ & $\bullet$ & & $\bullet d$ & $\bullet d$ & $\bullet d$ & $\bullet$ & $\bullet$ \\
\hline Strontium-90 & $\bullet$ & $\bullet$ & $\bullet$ & $\bullet$ & $\bullet$ & $\bullet$ & & $\bullet$ & $\bullet$ & $\bullet$ & $\bullet$ & \\
\hline
\end{tabular}

an addition to the specified samples shown for soils, liquid, sludge, or solid material present in tank, piping, or other container may also be analyzed for the same constituents, with the exclusion of asbestos. If the volume of material is limited, prioritization of the analyses will be necessary.

${ }^{\mathrm{b}}$ Add oil-range TPH.

${ }^{\mathrm{C}}$ May also include TCLP metals if sample is collected for waste management purposes.

${ }^{\mathrm{d}}$ Analysis for isotopic americium may be required for waste management purposes. 
Table A.1-7

\section{Proposed PCB Compounds for Analysis}

\begin{tabular}{|c|}
\hline PCB \\
\hline \hline Aroclor-1016 \\
Aroclor-1221 \\
Aroclor-1232 \\
Aroclor-1242 \\
Aroclor-1248 \\
Aroclor-1254 \\
Aroclor-1260 \\
\hline
\end{tabular}

Table A.1-8

\section{Proposed SVOCs for Analysis}

\begin{tabular}{||l|l|l|}
\hline \multicolumn{3}{|l|}{ Semivolatile Organic Compounds } \\
\hline \hline 1,2,4-Trichlorobenzene & 4-Chloro-3-methylphenol & Dibenzofuran \\
1,2-Dichlorobenzene & 4-Chloroaniline & Diethyl Phthalate \\
1,3-Dichlorobenzene & 4-Chlorophenyl phenyl ether & Dimethyl Phthalate \\
1,4-Dichlorobenzene & 4-Methylphenol & Di-n-butyl Phthalate \\
2,4,5-Trichlorophenol & 4-Nitroaniline & Di-n-octyl Phthalate \\
2,4,6-Trichlorophenol & 4-Nitrophenol & Fluoranthene \\
2,4-Dichlorophenol & Acenaphthene & Fluorene \\
2,4-Dimethylphenol & Acenaphthylene & Hexachlorobenzene \\
2,4-Dinitrophenol & Anthracene & Hexachlorobutadiene \\
2,4-Dinitrotoluene & Benzo(a)anthracene & Hexachlorocyclopentadiene \\
2,6-Dinitrotoluene & Benzo(a)pyrene & Hexachloroethane \\
2-Chloronaphthalene & Benzo(b)fluoranthene & Indeno(1,2,3-cd)pyrene \\
2-Chlorophenol & Benzo(g,h,i)perylene & Isophorone \\
2-Methylnaphthalene & Benzo(k)fluoranthene & Naphthalene \\
2-Methylphenol & Bis(2-chloroethoxy) methane & Nitrobenzene \\
2-Nitroaniline & Bis(2-chloroethyl)ether & N-nitroso-di-n-propylamine \\
2-Nitrophenol & Bis(2-ethylhexyl) phthalate & N-nitrosodiphenylamine \\
3,3'-Dichlorobenzidine & Butyl benzyl phthalate & Pentachlorophenol \\
3-Nitroaniline & Carbazole & Phenanthrene \\
4,6-Dinitro-2-methylphenol & Chrysene & Phenol \\
4-Bromophenyl phenyl ether & Dibenzo(a,h)anthracene & Pyrene \\
\hline
\end{tabular}


Table A.1-9

Proposed VOCs for Analysis

\begin{tabular}{|c|c|c|}
\hline \multicolumn{3}{|c|}{ Volatile Organic Compounds } \\
\hline 1,1,1,2-Tetrachloroethane & 2-Hexanone & Dibromomethane \\
\hline 1,1,1-Trichloroethane & 4-Methyl-2-pentanone & Dichlorodifluoromethane \\
\hline 1,1,2,2-Tetrachloroethane & Acetone & Ethylbenzene \\
\hline 1,1,2-Trichloroethane & Benzene & lodomethane \\
\hline 1,1-Dichloroethane & Bromoform & Methylene chloride \\
\hline 1,1-Dichloroethene & Bromomethane & Styrene \\
\hline 1,2,3-Trichloropropane & Carbon disulfide| & Tetrachloroethene \\
\hline 1,2-Dibromo-3-chloropropane & Carbon tetrachloride & Toluene \\
\hline 1,2-Dibromoethane & Chlorobenzene & Trichloroethene \\
\hline 1,2-Dichloroethane & Chloroethane & Trichlorofluoromethane \\
\hline 1,2-Dichloropropane & Chloroform & Vinyl acetate \\
\hline 1,4-Dichlorobenzene & Chloromethane & Vinyl chloride \\
\hline 2-Butanone & Dibromochloromethane & \\
\hline
\end{tabular}

additional samples may not directly support Phase I decision-making, they will be used if a CAS is elevated to Phase II to define contamination extent.

The potential Phase II sampling target populations for each CAS are:

- COC concentrations in soil at step-out locations

- COC concentrations in soil below the contaminant plume(s)

Phase II target populations will be limited to those related to distinct Phase I target populations with COCs. These target populations represent locations within the system that, when sampled, will provide sufficient data to address the Phase II data needs discussed in Section A.1.3.

\section{A.1.4.2 Identify the Spatial and Temporal Boundaries}

The spatial boundaries that apply to each CAS in Phase I are the survey and sample locations selected for Phase I. The spatial boundaries that apply to each CAS for Phase II are shown in Table A.1-11. In general, geographic boundaries are defined by the impacted soil. Intrusive activities are not intended to extend into CASs not in CAU 127.

Temporal boundaries are time constraints due to time-related phenomena, such as weather conditions, seasons, activity patterns, etc. Significant temporal constraints due to weather conditions are not expected. Moist weather may place constraints on sampling and field-screening contaminated soils 
Table A.1-10

Target Populations for the Phase I Investigations

\begin{tabular}{|c|c|}
\hline CAS & Target Population \\
\hline $25-01-05$ & $\begin{array}{l}\text { COC concentrations in surface soil near tank, especially near overflow pipe. COC } \\
\text { concentrations in subsurface soil below tank and below piping running between tank } \\
\text { and USTs (CAS 25-02-02). COC concentrations in tank contents for waste } \\
\text { characterization. }\end{array}$ \\
\hline $25-02-02$ & $\begin{array}{l}\text { COC concentrations in surface soil near the aboveground pressure valve and the } \\
\text { aboveground piping above the USTs; COC concentrations in subsurface soil at the } \\
\text { these locations, as well as soil adjacent to USTs, under piping between USTs and } \\
\text { former filter tanks, and adjacent to piping from USTs to pump vault (CAS 25-23-11). } \\
\text { COC concentrations in surface and subsurface soil at the former location of the filter } \\
\text { tanks (includes berms around location). COC concentrations in tank contents for } \\
\text { waste characterization. }\end{array}$ \\
\hline $25-23-11$ & $\begin{array}{l}\text { COC concentrations in surface and subsurface soil near heat shield and pump vault. } \\
\text { COC concentrations of materials in pump vault. Radiological characterization of } \\
\text { surfaces of accessible pipes, concrete, pump, and debris for waste characterization. }\end{array}$ \\
\hline $25-12-01$ & $\begin{array}{l}\mathrm{COC} \text { concentrations in materials within boiler for waste characterization. Radiological } \\
\text { characterization of surfaces of accessible pipes, pumps, concrete pad, and boiler for } \\
\text { waste characterization. }\end{array}$ \\
\hline $25-01-06$ & $\begin{array}{l}\text { COC concentrations in surface and subsurface soil on north side of concrete pad under } \\
\text { tank. }\end{array}$ \\
\hline $25-01-07$ & $\begin{array}{l}\text { COC concentrations in surface and subsurface soil on north side of concrete pad under } \\
\text { tank. }\end{array}$ \\
\hline $25-02-13$ & $\begin{array}{l}\text { COC concentrations on gravel/soil on the floor of the X-Tunnel experiment chamber } \\
\text { over the former location of the underground tank. }\end{array}$ \\
\hline $26-01-01$ & $\begin{array}{l}\text { COC concentrations in surface and subsurface soil under/adjacent to tank and piping. } \\
\text { Radiological characterization of surfaces of pipes and tank for waste characterization. } \\
\text { COC concentrations in tank contents for waste characterization. }\end{array}$ \\
\hline $26-01-02$ & $\begin{array}{l}\text { COC concentrations in surface and subsurface soil under/adjacent to tank and piping. } \\
\text { Radiological characterization of surfaces of pipes and tank for waste characterization. } \\
\mathrm{COC} \text { concentrations in tank contents for waste characterization. }\end{array}$ \\
\hline $26-99-01$ & $\begin{array}{l}\text { COC concentrations in the surface and subsurface soil under the shed housing the } \\
\text { radioactively contaminated filters. Radiological characterization of surfaces of pipes, } \\
\text { filter tanks, and shed for waste characterization. COC concentrations in filter media for } \\
\text { waste characterization. }\end{array}$ \\
\hline $26-02-01$ & $\begin{array}{l}\mathrm{COC} \text { concentrations in subsurface soil under base of tank. } \mathrm{COC} \text { concentrations in } \\
\text { tank contents for waste characterization. }\end{array}$ \\
\hline $26-23-01$ & $\begin{array}{l}\text { COC concentrations in surface and possibly shallow subsurface soil from area below } \\
\text { and immediately adjacent to spreader. Radiological characterization of inside and } \\
\text { outside surfaces of spreader for waste characterization. COC concentrations in tank } \\
\text { contents for waste characterization. }\end{array}$ \\
\hline
\end{tabular}


Table A.1-11

Spatial Boundaries for Phase II Investigation

\begin{tabular}{|c|c|c||}
\hline \multirow{2}{*}{ CAS } & \multicolumn{2}{|c|}{ Spatial Boundary } \\
\cline { 2 - 3 } & Horizontal & Vertical \\
\hline \hline $25-01-05$ & $50-\mathrm{ft}$ buffer around the CAS & $30 \mathrm{ft}$ bgs \\
\hline $25-02-02$ & $50-\mathrm{ft}$ buffer around the CAS & $50 \mathrm{ft} \mathrm{bgs}$ \\
\hline $25-23-11$ & $50-\mathrm{ft}$ buffer around the CAS & $30 \mathrm{ft}$ bgs \\
\hline $25-12-01$ & $30-\mathrm{ft}$ buffer around the CAS & $0 \mathrm{ft}$ bgs \\
\hline $25-01-06$ & $50-\mathrm{ft}$ buffer around the CAS & $30 \mathrm{ft}$ bgs \\
\hline $25-01-07$ & $50-\mathrm{ft}$ buffer around the CAS & $30 \mathrm{ft}$ bgs \\
\hline $26-01-01$ & $50-\mathrm{ft}$ buffer around the CAS & $30 \mathrm{ft}$ bgs \\
\hline $26-01-02$ & $50-\mathrm{ft}$ buffer around the CAS & $30 \mathrm{ft}$ bgs \\
\hline $26-99-01$ & $50-\mathrm{ft}$ buffer around the CAS & $30 \mathrm{ft}$ bgs \\
\hline $26-02-01$ & $50-\mathrm{ft}$ buffer around the CAS & $30 \mathrm{ft}$ bgs \\
\hline $26-23-01$ & $30-\mathrm{ft}$ buffer around the CAS & $10 \mathrm{ft}$ bgs \\
\hline
\end{tabular}

because of the attenuating effect of moisture in samples. There are no time constraints on collecting samples as environmental conditions at all sites will not significantly change in the near future and conditions would have stabilized over the years since the sites were last used.

\section{A.1.4.3 Identify Practical Constraints}

Nevada Test Site-controlled activities may affect the ability to characterize these CASs, although the sites are generally abandoned, without any ongoing activity. The exception to this is the X-Tunnel, location of CAS 25-02-13, which is inactive not abandoned. Also, CAS 26-02-01, the Check Station, has recently been demolished. The aboveground piping associated with this site has been removed, which would have disturbed the nearby surface soils, and impacted the representativeness of data from surface soil samples. Table A.1-12 indicates other practical constraints that may be encountered at each CAS. 
Table A.1-12

Practical Constraints Identified for CAU 127

\begin{tabular}{|c|c|c|c|c|c|}
\hline CAS & $\begin{array}{c}\text { Utilities } \\
\text { Likely to be }^{\text {Encountered }}\end{array}$ & $\begin{array}{c}\text { Topography/Site } \\
\text { Conditions Likely } \\
\text { to Affect Planned } \\
\text { Activities }\end{array}$ & $\begin{array}{c}\text { Structures } \\
\text { (Tanks/Pipes/BIdgs) } \\
\text { Likely to Affect } \\
\text { Planned Activities }\end{array}$ & $\begin{array}{l}\text { Area Subject } \\
\text { to Access } \\
\text { Restrictions }^{b}\end{array}$ & $\begin{array}{c}\text { Confined } \\
\text { Space, Health \& } \\
\text { Safety, } \\
\text { Structural } \\
\text { Integrity Issues }\end{array}$ \\
\hline 25-01-05 & None known & No & No & Yes & Yes \\
\hline $25-02-02$ & None known & No & No & Yes & Yes \\
\hline $25-23-11$ & None known & No & Yes & Yes & Yes \\
\hline $25-12-01$ & None known & No & Yes & Yes & Yes \\
\hline $25-01-06$ & None known & No & No & Yes & No \\
\hline $25-01-07$ & None known & No & No & Yes & No \\
\hline $25-02-13$ & None known & Yes & Yes & Yes & Yes \\
\hline 26-01-01 & None known & No & Yes & Yes & Yes \\
\hline 26-01-02 & None known & No & Yes & Yes & Yes \\
\hline $26-99-01$ & None known & No & Yes & Yes & Yes \\
\hline $26-02-01$ & None known & No & No & No & No \\
\hline $26-23-01$ & None known & No & No & Yes & No \\
\hline
\end{tabular}

Source: Site visits.

${ }^{a}$ Utility constraints are subject to change as detailed information is collected prior to commencement of investigation activities and will be appropriately documented. All CASs will be surveyed for utilities prior to field activities in accordance with the SSHASP. Does not include underground piping that is included as part of the CAS.

${ }^{b}$ Access restrictions include both scheduling conflicts on the NTS with other entities and areas posted as contamination areas requiring appropriate work controls, and areas requiring authorized access.

\section{A.1.4.4 Define the Scale of Decision Making}

The scale of decision making in Phase I is defined as the CAS. The scale of decision making in Phase II is defined as the maximum extent of COC contamination. The scale of decision making for an unrestricted release determination is the entire object/structure (e.g., tank, pipe) surveyed.

\section{A.1.5 Step 5 - Develop a Decision Rule}

This step integrates outputs from the previous steps with the inputs developed in this step into a decision rule ("If..., then...") statement. This rule describes the conditions under which possible alternative actions would be chosen. 


\section{A.1.5.1 Specify the Population Parameter}

The maximum observed concentration of each COC will be the population parameter. If radiological surveys are performed, radiological sampling results will supersede radiological survey results.

\section{A.1.5.2 Choose an Action Level}

Action levels are defined in Section A.1.1.3.2.

\section{A.1.5.3 Measurement and Analysis Methods}

The analyses identified in Section A.1.3.3 for each CAS will be used to identify the presence, location, and extent of COCs in the investigation. Indicators (e.g., field conditions, process knowledge) may also be used to identify the presence and location of COCs. At selected CASs, radiological surveys will also be used to identify the presence and location of COCs.

The measurement and analysis methods in the Industrial Sites QAPP (DOE/NV, 2002) are capable of achieving the expected range of values to resolve the Phase I and II decisions. The detection limit of the measurement method to be used is less than the PAL for each COPC, unless specified otherwise in the CAIP.

\section{A.1.5.4 Decision Rule}

Phase I Decision: If the concentration of any COPC in a target population exceeds the PAL for that COPC, then that COPC is identified as a COC, and a Phase II investigation will be conducted. If it is determined that sufficient indicators are present, then Phase I can be terminated and a Phase II investigation initiated. If the COPC concentration is less than the PAL, then the decision will be no further action.

Phase II Decision: If the maximum observed concentration of any COC of a target population exceeds the PALs, then additional samples will be collected to define extent. If the observed concentration is less than the PAL, then the decision will be that the extent of contamination has been defined in the vertical and/or horizontal direction. 
If contamination is inconsistent with the CSM or extends beyond the spatial boundaries identified in Table A.1-11, then work will be suspended and the investigation strategy will be reevaluated. If contamination is consistent with the CSM and is within spatial boundaries, then the decision will be to continue sampling to define extent.

\section{A.1.6 Step 6 - Specify the Tolerable Limits on Decision Errors}

The sampling approach for the CAU 127 investigation relies on biased sampling locations. Only validated analytical results (quantitative data) will be used to determine if COCs are present. The baseline condition (i.e., null hypothesis) and alternative condition for Phase I are:

- Baseline condition - A COC is present

- Alternative condition - A COC is not present

The baseline condition (i.e., null hypothesis) and alternative condition for Phase II are:

- Baseline condition - The extent of a COC has not been defined.

- Alternative condition - Extent of a COC has been defined.

Decisions and/or criteria have an alpha (false negative) or beta (false positive) error associated with their determination (discussed in the following subsections). Since quantitative data are individually compared to action levels, statistical evaluations of the data such as averages or confidence intervals are not appropriate.

\section{A.1.6.1 False Negative Decision Error}

The false negative (rejection or alpha) decision error would mean deciding that a COC is not present when it is, increasing risk to human health and environment.

A false negative decision error (where consequences are more severe) is controlled by meeting these criteria: (1) having a high degree of confidence that the sample locations selected will identify COCs if present anywhere within the CAS or that the locations will identify the extent of COCs, and (2) having a high degree of confidence that analyses conducted will be sufficient to detect any COCs present in the samples. 
To satisfy the first criterion, Phase I samples will be collected in areas most likely to be contaminated by any COCs and Phase II samples will be collected in areas that represent the lateral and vertical extent of contamination. To accomplish this, the following characteristics are considered:

- Source and location of release

- Chemical nature and fate properties

- Physical transport pathways and properties

- Hydrologic drivers

These characteristics were considered during the development of the CSMs. The biasing factors listed in Section A.1.3.1 will be used to further ensure that the first criterion is met.

To satisfy the second criterion, all Phase I samples and Phase II samples (when Phase I data are not yet available) will be analyzed for the chemical and radiological parameters listed in Section A.1.3.3 using analytical methods that are capable of producing quantitative data to concentrations below or equal to PALs (unless stated otherwise in the CAIP). For Phase II samples, when Phase I data are available, samples will be analyzed for only those chemical and radiological parameters that have been identified as COCs in the Phase I samples. Strict adherence to established procedures and QA/QC protocol protects against false negatives.

\section{A.1.6.2 False Positive Decision Error}

The false positive (acceptance or beta) decision error would mean deciding that a COC is present when it is not, or accepting that the extent of a COC has not been defined when it really has, resulting in increased costs for unnecessary characterization.

The false positive decision error is controlled by protecting against false positive analytical results. False positive results are typically attributed to laboratory and/or sampling/handling errors. Quality assurance/quality control samples such as field blanks, trip blanks, laboratory control samples, and method blanks minimize the risk of a false positive analytical result. Other measures include proper decontamination of sampling equipment and using certified clean sample containers to avoid cross contamination. 


\section{A.1.6.3 Quality Assurance/Quality Control}

Radiological survey instruments will be calibrated in accordance with manufacturer's instructions and periodic calibrations will be performed in accordance with approved procedures. Quality control samples will be collected as required by established procedures. The required QC samples include:

- Trip blanks (one per sample cooler containing VOC environmental samples)

- Equipment blanks (one per sampling event for each type of decontamination procedure)

- Source blanks (one per source lot per sampling event)

- Field duplicates (minimum of 1 per matrix per 20 environmental samples or 1 per CAS if less than 20 collected)

- Field blanks (minimum of per one CAS)

- Matrix spike/matrix spike duplicate (minimum of 1 per matrix per 20 environmental samples or 1 per CAS if less than 20 collected). The MS/MSD is not needed for some radioanalytical measurements (e.g., gamma spectrometry).

Additional QC samples may be submitted based on site conditions.

Data Quality Indicators of precision, accuracy, comparability, completeness, and representativeness are defined in the Industrial Sites QAPP (DOE/NV, 2002). In addition, sensitivity has been included as a DQI for laboratory analyses. Site-specific DQIs are discussed in more detail in Section 6.0 of the CAIP.

\section{A.1.7 Step 7 - Optimize the Design for Obtaining Data}

Radiological surveys and intrusive sampling will be conducted at CAU 127 during Phase I. Radiological surveys will be conducted at eight of the CASs to estimate the lateral extent of contamination and/or identify hot spots for subsequent sampling or swiping. A radiological survey of $\mathrm{X}$-Tunnel floor will be performed at the former location of the CAS 25-02-13 underground tank to confirm the absence of contamination.

Soil sampling locations will be determined based on the results of the surveys and other biasing factors listed in Section A.1.3.1. These locations may be modified, but only if the modified locations 
meet the decision needs and criteria stipulated in Section A.1.3. As noted in Section A.1.3.3 and Section A.1.4.1, some sampling will be performed for waste characterization purposes. Section A.1.7.1 and Section A.1.7.2 provide information on general investigation activities. Section A.1.7.3 provides the planned Phase I sampling strategy for each CAS in CAU 127 except CASs 25-01-06 and 25-01-07. The investigation of these two CASs will proceed directly to Phase II, since soil contamination is known to be present. The Phase II strategy is presented in Section A.1.7.4.

\section{A.1.7.1 Radiological Survey Methodologies and Instruments}

Radiological surveys will be conducted at eight CASs to define the lateral extent of surficial contamination and/or to locate hot spots for subsequent sampling or swiping. Walk-over surveys using handheld instruments will be performed on those portions of the CASs that are accessible. The walk-over surveys will be conducted on each CAS in such a manner as to ascertain if radiological contamination is present and is decreasing as the distance from the tanks/piping/etc. increases, as CSM \#1 would predict. Additionally, if elevated surface readings are encountered, an effort will be made through in situ screening techniques to identify the source term as being either a surface/shallow subsurface source term or a subsurface source term. The NE Technology Electra, Eberline E-600, TSA-PRM-470B and Bicron mRem or equivalent instruments will be used in the appropriate capacity as the handheld instruments. As discussed above, a confirmatory walk-over radiological survey of the tunnel floor will be conducted at the former location of the CAS 25-02-13 underground tank.

Some radiological screening, surveying, and swipe collection will take place for waste characterization purposes. These activities will assess the amount of fixed and removable contamination on the surfaces of pipes, tanks, concrete, and possibly other objects. When necessary, detectors or probes on extended cables will be lowered into structures to collect measurements, and swipes will be affixed to extension poles or fish tapes to obtain data from the interior of structures or objects.

Additional equipment and software used in the radiological data collection and processing include a GPS receiver, such as Trimble or Motorola, and associated laptop computers to log and process the 
walk-over radiological data. Mapping programs such as ArcView, Surfer, and EarthVision will be used to plot data on site maps or aerial photographs.

\section{A.1.7.2 Intrusive Investigation}

Intrusive investigations will be conducted at 10 of the CASs to determine if a COC is present. An intrusive investigation is not planned for the boiler and associated features at Test Cell $\mathrm{C}$ (CAS 25-12-01) or the former UST location in the X-Tunnel (CAS 25-02-13). Samples from each of the 10 sites will be collected from biased locations. The sampling locations will be determined based on the results of the radiological surveys and other biasing factors listed in Section A.1.3.1.

Rotary sonic drilling, hollow-stem auger drilling, direct-push, handheld augers, or excavation will be used to access sample intervals for laboratory analysis at select locations to determine if a COC is present. Due to the potentially dangerous nature of buried features (i.e., tanks, piping, utilities, asbestos), sample locations may be biased adjacent to any buried feature, based upon the review of engineering drawings, and information obtained during site walkovers. The locations may also be biased, based upon specific site conditions encountered. Surface soil samples $(<0.5 \mathrm{ft}$ bgs $)$ will be collected by hand according to approved procedures.

\section{A.1.7.3 Phase I Sampling Strategy}

The planned Phase I sampling strategy for each CAS is listed in Table A.1-13. The biasing factors listed in Section A.1.3.1 will be used to determine sampling locations. Where soil sampling is proposed in Table A.1-13, if FSRs above FSLs or other biasing factors indicate the presence of contamination at levels above the PALs, a Phase II investigation will be instituted.

The collection of samples of tank contents for waste characterization are dependent on the accessibility and availability of the contents. The determination that tank contents can be sampled will be made in the field. If distinct phases are identified, if possible, a sample of each phase will be collected for analysis. If there is evidence of leakage from any of the CAU tanks/piping, any liquids remaining in the tanks will be removed as soon as possible. 
Table A.1-13

Planned Phase I Sampling Strategy

(Page 1 of 3 )

\begin{tabular}{|c|c|}
\hline CAS & Sampling Strategy ${ }^{a}$ \\
\hline $\begin{array}{c}25-01-05 \\
\text { Test Cell C } \\
100,000 \text {-gal AST }\end{array}$ & $\begin{array}{l}\text { Sample and analyze contents of tank, if sufficient material is present. } \\
\text { Perform radiological survey of ground within a } 20 \text {-ft perimeter of tank and along the length } \\
\text { of piping ( } 10 \mathrm{ft} \text { either side). Pump pad/vault may still be present at northwest end of pipes. } \\
\text { If present, perform radiological survey of pumps and pad/vault. } \\
\text { Minimum of two surface soil samples around the base of the tank, locations based on } \\
\text { biasing factors. Two subsurface soil samples, using angle boring, under footprint of tank. } \\
\text { Minimum of three subsurface soil samples, locations based on biasing factors, along the } \\
\text { length of the underground pipe running to CAS } 25-23-11 \text {. Include pump pad/vault in this } \\
\text { area. Sample interval will begin at the base of the pipe. } \\
\text { Minimum of one sample of suspected ACM on pipes. }\end{array}$ \\
\hline $\begin{array}{c}25-02-02 \\
\text { Test Cell C } \\
\text { six 10,000-gal USTs }\end{array}$ & $\begin{array}{l}\text { Sample and analyze contents of tanks, if sufficient material is present. } \\
\text { Perform radiological survey of ground within } 20 \mathrm{ft} \text { of approximated outline of tanks, and } \\
\text { along the length of piping ( } 10 \mathrm{ft} \text { either side). Perform radiological survey around, over, and } \\
\text { within bermed area that previously held filter tanks (extend } 20 \mathrm{ft} \text { beyond outer toe of berms). } \\
\text { This survey will also be used for CAS } 25-23-11 \text {. Conduct downhole radiological survey of } \\
\text { tank interior(s) if access is available (e.g., through vent risers) and if tank contents are not } \\
\text { sampled. } \\
\text { Minimum of one surface soil sample, next to aboveground piping over USTs, locations } \\
\text { based upon biasing factors. } \\
\text { Minimum of six soil sample locations (surface and subsurface) in soil berms around the filter } \\
\text { tank area (outside, top, and inside berm surfaces), locations based upon biasing factors. } \\
\text { Locations at top of berm will be surface soil sample locations only. } \\
\text { Minimum of one subsurface soil sample within the bermed area, immediately off the } \\
\text { concrete pad, location based upon biasing factors. } \\
\text { Minimum of two subsurface soil samples adjacent to pump vault, location based upon } \\
\text { biasing factors. Sample intervals will be below the base of CAS } 25-23-11 \text { pump vault. } \\
\text { (Note: Soil above base of vault is addressed in investigation of CAS } 25-23-11 \text { ). } \\
\text { Minimum of one subsurface soil sample, below the underground pipe running to } \\
\text { CAS } 25-23-11 \text {, sample interval will begin at the base of the pipe. } \\
\text { Subsurface soil samples as near as possible to tanks, minimum of four sample locations, } \\
\text { based upon biasing factors. Samples on the northeast side of the tanks will be obtained by } \\
\text { extending the depths of the sampling locations inside of the bermed area. } \\
\text { Minimum of one sample of suspected ACM on pipes. }\end{array}$ \\
\hline
\end{tabular}


Table A.1-13

Planned Phase I Sampling Strategy

(Page 2 of 3 )

\begin{tabular}{|c|c|}
\hline CAS & Sampling Strategy ${ }^{a}$ \\
\hline $\begin{array}{l}\text { 25-23-11 } \\
\text { Test Cell C } \\
\text { Contaminated Materials }\end{array}$ & $\begin{array}{l}\text { Perform radiological survey within } 20 \mathrm{ft} \text { of pump vault. } \\
\text { Perform limited radiological characterization of exterior and accessible interior surfaces of } \\
\text { pump, pipes, concrete vault, and heat shield, as appropriate (suspected ACM will not be } \\
\text { disturbed to access surfaces). } \\
\text { Minimum of two surface soil samples, locations based upon biasing factors. Exact } \\
\text { locations will be based upon accessibility, due to piping and heat shield conflict. (Note: } \\
\text { subsurface soil at these locations will be addressed by the investigation of CAS 25-02-02.) } \\
\text { Minimum of one sample of suspected ACM on pipes. }\end{array}$ \\
\hline $\begin{array}{c}\text { 25-12-01 } \\
\text { Test Cell C Boiler }\end{array}$ & $\begin{array}{l}\text { Sample and analyze contents of boiler, if sufficient material is present. } \\
\text { Perform radiological survey of ground within } 20 \mathrm{ft} \text { of boiler, and within } 10 \mathrm{ft} \text { of other features } \\
\text { included in CAS. } \\
\text { Perform limited radiological characterization of exterior and accessible interior surfaces of } \\
\text { boiler and other features included in CAS, as appropriate (suspected ACM will not be } \\
\text { disturbed to access surfaces). } \\
\text { Minimum of one sample of suspected ACM on boiler and/or pipes. }\end{array}$ \\
\hline $\begin{array}{l}\text { 25-02-13 } \\
\text { X-Tunnel UST }\end{array}$ & $\begin{array}{l}\text { Perform a confirmatory radiological survey of the tunnel experiment chamber floor at the } \\
\text { former location of the underground tank. The excavation associated with the tank removal } \\
\text { was approximately } 10 \mathrm{ft} \text { by } 8 \mathrm{ft} \text {. Due to uncertainty in the precise location of the excavation, } \\
\text { the radiological survey will include an area of at least } 20 \mathrm{ft} \text { by } 20 \mathrm{ft} \text {. }\end{array}$ \\
\hline $\begin{array}{c}25-01-06 \\
\text { E-MAD 1,000-gal AST }\end{array}$ & Proceed to Phase II sampling. \\
\hline $\begin{array}{c}25-01-07 \\
\text { E-MAD 1,000-gal AST }\end{array}$ & Proceed to Phase II sampling. \\
\hline $\begin{array}{c}\text { 26-01-01 } \\
\text { Project Pluto } \\
\text { Disassembly Facility } \\
\text { 10,000-gal Filter Tank } \\
\text { (RAD) and Piping }\end{array}$ & $\begin{array}{l}\text { Sample and analyze contents of tank, if sufficient material is present. } \\
\text { Perform radiological survey of ground within } 20 \mathrm{ft} \text { of tank and along the length of piping ( } 5 \mathrm{ft} \\
\text { on either side). } \\
\text { Perform limited radiological characterization of exterior and accessible interior surfaces of } \\
\text { tank and aboveground pipes, as appropriate (suspected ACM will not be disturbed to } \\
\text { access surfaces). } \\
\text { Minimum of four surface and subsurface soil sample locations beneath and immediately } \\
\text { adjacent to the tank and aboveground piping, based upon biasing factors. } \\
\text { Minimum of three subsurface soil samples along the length of the underground pipe running } \\
\text { from CAS } 26-01-01 \text { to the previous location of the CAS } 26-02-04 \text { UST. Locations will be } \\
\text { based upon biasing factors, and sample intervals will begin at the base of the pipe. } \\
\text { Minimum of one sample of suspected ACM on pipes. }\end{array}$ \\
\hline
\end{tabular}


Table A.1-13

Planned Phase I Sampling Strategy

(Page 3 of 3 )

\begin{tabular}{|c|c|}
\hline CAS & Sampling Strategy ${ }^{a}$ \\
\hline $\begin{array}{l}\text { 26-01-02 } \\
\text { Project Pluto } \\
\text { Disassembly Facility } \\
\text { 5,000-gal Filter Tank }\end{array}$ & $\begin{array}{l}\text { Sample and analyze contents of tank, if sufficient material is present. } \\
\text { Perform radiological survey of ground within } 20 \mathrm{ft} \text { of tank, and along the length of piping ( } 5 \mathrm{ft} \\
\text { either side). } \\
\text { Perform limited radiological characterization of exterior and accessible interior surfaces of } \\
\text { tank and aboveground pipes, as appropriate (suspected ACM will not be disturbed to } \\
\text { access surfaces). } \\
\text { Minimum of four surface and subsurface soil locations beneath and immediately adjacent to } \\
\text { the tank and aboveground piping, based upon biasing factors. } \\
\text { Minimum of one sample of suspected ACM on pipes. }\end{array}$ \\
\hline $\begin{array}{c}\text { 26-99-01 } \\
\text { Project Pluto } \\
\text { Disassembly Facility } \\
\text { Radioactively } \\
\text { Contaminated Filters }\end{array}$ & $\begin{array}{l}\text { Sample and analyze contents of tanks/filters, if sufficient material is present. } \\
\text { Perform radiological survey of ground within } 20 \mathrm{ft} \text { of shed. } \\
\text { Perform limited radiological characterization of exterior and accessible interior surfaces of } \\
\text { filter tanks, aboveground pipes, and shed, as appropriate (suspected ACM will not be } \\
\text { disturbed to access surfaces). } \\
\text { Minimum of three surface and subsurface soil sample locations beneath and immediately } \\
\text { adjacent to the building, based upon biasing factors. } \\
\text { Minimum of one sample of suspected ACMs on pipes and/or other features. }\end{array}$ \\
\hline $\begin{array}{l}\text { 26-02-01 } \\
\text { Project Pluto Check } \\
\text { Station 1,000-gal UST }\end{array}$ & $\begin{array}{l}\text { Sample and analyze contents of tank, if sufficient material is present. } \\
\text { Two subsurface soil samples, immediately adjacent to the tank, locations based upon } \\
\text { biasing factors. Sample interval will begin at the base of the tank. }\end{array}$ \\
\hline $\begin{array}{c}\text { 26-23-01 } \\
\text { Port Gaston } \\
\text { Contaminated Liquids } \\
\text { Spreader }\end{array}$ & $\begin{array}{l}\text { Sample and analyze contents of two tanks (it is suspected tanks are dry). } \\
\text { Perform limited radiological characterization of exterior and accessible interior of surfaces } \\
\text { of tanks, hoses, pipes, wheels, frames, etc., as appropriate. } \\
\text { Perform radiological survey of area within } 20 \mathrm{ft} \text { radius of spreader. } \\
\text { Minimum of three surface soil samples beneath or immediately adjacent to the spreader, } \\
\text { locations based upon biasing factors. }\end{array}$ \\
\hline
\end{tabular}

${ }^{a}$ The sampling locations may be altered based upon additional information. 


\section{A.1.7.4 Phase II Sampling Strategy}

Biased soil sampling for laboratory analysis will be conducted at CAU 127 during Phase II. Biased sampling locations will be estimated prior to Phase II, based on process knowledge and analytical results from Phase I, if available. As field data are generated (e.g., radiological surveys, field-screening, and Phase I analytical results), the Phase II locations may be modified as long as they meet the decision needs and criteria stipulated in Section A.1.3.

Lateral step-out sample points will be located a maximum of $15 \mathrm{ft}$ from outer boundary sample locations where COCs were detected. If biasing factors indicate COCs extend beyond the proposed Phase II sample locations, further step-out locations may be necessary. At each Phase II lateral step-out location, soil samples will be collected at the depth(s) where COCs were encountered and at 2-ft intervals below the lowest depth where COCs were encountered. Phase II sampling to define the vertical extent of contamination will begin $2 \mathrm{ft}$ below the depth where COCs were detected. In general, samples submitted for laboratory analysis would be those that define the lateral and vertical extent of COCs. Additional samples may be collected to define the extent of COCs if necessary.

At each sample location, sampling will continue until two consecutive soils samples with screening results below FSLs are collected or a hold point (Table A.1-11) is reached. In addition to screening results below FSLs, these two consecutive sample intervals will also be characterized by the absence of other indicators of contamination (e.g., odors or staining). The extent of contamination will be defined by submitting one of these below-FSL samples (generally, the uppermost sample) for laboratory analysis to confirm the absence of COCs. If the analyzed sample is below PALs, then extent will be considered to be determined. Accordingly, not every interval that is collected for field screening will be submitted for laboratory analysis; the protocol is discussed in the CAIP.

Based on current site conditions, the investigations of CASs 25-01-06 and 25-01-07 will proceed directly to Phase II. The sampling strategy for these CASs is listed in Table A.1-14. 
Table A.1-14

Planned Phase II Sampling Strategy

\begin{tabular}{||c|l||}
\hline \hline CAS & \multicolumn{1}{|c|}{ Sampling Strategy ${ }^{\mathrm{a}}$} \\
\hline \hline E-MAD 1,000-gal AST & $\begin{array}{l}\text { Minimum of two soil samples within the stained soil area-one surface and one shallow } \\
\text { subsurface. } \\
\text { Minimum of one surface and one subsurface soil sample in each direction (north, east, and } \\
\text { west), approximately } 3 \mathrm{ft} \text { beyond the visibly stained surface soil. Final sample locations } \\
\text { and sample depths will be based upon biasing factors. Analyze samples that do not } \\
\text { exceed FSLs in order to confirm delineation of contamination extent. If contamination } \\
\text { extends beyond these limits, step-out locations at additional distance and/or depth, as } \\
\text { necessary, will be sampled. }\end{array}$ \\
\hline E-MAD 1,000-gal AST & $\begin{array}{l}\text { Minimum of two soil samples within the stained soil area-one surface and one shallow } \\
\text { subsurface. } \\
\text { Minimum of one surface and one subsurface soil sample in each direction (north, east, and } \\
\text { west), approximately } 3 \mathrm{ft} \text { beyond the visibly stained surface soil. Final sample locations } \\
\text { and sample depths will be based upon biasing factors. Analyze samples that do not } \\
\text { exceed FSLs in order to confirm delineation of contamination extent. If contamination } \\
\text { extends beyond these limits, step-out locations at additional distance and/or depth, as } \\
\text { necessary, will be sampled. }\end{array}$ \\
\hline
\end{tabular}

${ }^{a}$ The sampling locations may be altered based upon additional information. 


\section{A.2.0 References}

Bastian, C.T., Bechtel Nevada. 1996. Memorandum to J.A. Carpenter (LANL) and J.M. Haeberlin (LLNL) entitled, "Final Radiological Report for the X-Tunnel," 12 August. Las Vegas, NV.

Desert Research Institute. 1988. CERCLA Preliminary Assessment of DOE's Nevada Operations Office Nuclear Weapons Testing Areas, Vol. 1. Las Vegas, NV: Water Resource Center.

DOE, see U.S. Department of Energy.

DOE/NV, see U.S. Department of Energy, Nevada Operations Office.

DRI, see Desert Research Institute.

EPA, see U.S. Environmental Protection Agency.

McArthur, R.D., and F.L. Miller, Jr. 1989. Off-Site Radiation Exposure Review Project, Phase II Soil Program, DOE/NV/10384-23. Las Vegas, NV: Desert Research Institute.

Moore, J., Science Applications International Corporation. 1999. Memorandum to M. Todd (SAIC) entitled, "Background Concentrations for NTS and TTR Soil Samples," 3 February. Las Vegas, NV: IT Corporation.

NAC, see Nevada Administrative Code.

NBMG, see Nevada Bureau of Mines and Geology.

Nevada Administrative Code. 1996. NAC 445A.227, "Contamination of Soil: Order by Director for Corrective Action; Factors to be Considered in Determining whether Corrective Action Required." Carson City, NV.

Nevada Administrative Code. 2002. NAC 445A.2272, "Contamination of Soil: Establishment of Action Levels." Carson City, NV.

Nevada Bureau of Mines and Geology. 1998. Mineral and Energy Resource Assessment of the Nellis Air Force Range, Open-File Report 98-1. Reno, NV.

U.S. Department of Energy. 2002. Final Environmental Impact Statement for a Geologic Repository for the Disposal of Spent Nuclear Fuel and High-Level Radioactive Waste at Yucca Mountain, Nye County, Nevada, DOE/EIS-0250, Volume 1. Las Vegas, NV: Office of Civilian Radioactive Waste Management. 
U.S. Department of Energy, Nevada Operations Office. 1996. Environmental Data Report for the Nevada Test Site - 1994. Prepared by S.C. Black and Y.E. Townsend. Las Vegas, NV.

U.S. Department of Energy, Nevada Operations Office. 1998. Nevada Test Site Resource Management Plan, DOE/NV--518. Las Vegas, NV.

U.S. Department of Energy, Nevada Operations Office. 2000. NV/YMP Radiological Control Manual, DOE/NV/11718-079, Rev. 4. Prepared by Bechtel Nevada. Las Vegas, NV.

U.S. Department of Energy, Nevada Operations Office. 2002. Industrial Sites Quality Assurance Project Plan, Nevada Test Site, Nevada, Rev. 3, DOE/NV--372. Las Vegas, NV.

US Ecology and Atlan-Tech. 1992. Environmental Monitoring Report for the Proposed Ward Valley, California, Low-Level Radioactive Waste (LLRW) Facility. Rosewell, GA.

U.S. Environmental Protection Agency. 2002. Region IX Preliminary Remediation Goals (PRGs). Available at www.epa.gov/region09/waste/sfund/prg, updated 22 November, accessed on 06/03/2002. San Francisco, CA.

USGS, see U.S. Geological Survey.

U.S. Geological Survey. 1964. Geology of the Pluto Site, Area 401, Nevada Test Site, Nye County, Nevada, USGS-TEI-841. Prepared by R.B. Johnson and J.R. Ege. Denver, CO.

U.S. Geological Survey. 1975. Hydrogeologic and Hydrochemical Framework, South-Central Great Basin, Nevada-California, with Special Reference to the Nevada Test Site, USGS Professional Paper 712-C. Prepared by I.J. Winograd and W. Thordarson. Washington, DC.

U.S. Geological Survey. 1995. Selected Ground-Water Data for Yucca Mountain Region, Southern Nevada and Eastern California, Calender Year 1993, USGS-OFR-158. Prepared by G.S. Hale and C.L. Westernburg. Denver, CO. 
CAU 127 Closure Report

Section: Appendix B

Revision: 0

Date: February 2008

\section{APPENDIX B}

\section{SAMPLE ANALYTICAL RESULTS}


CAU 127 Closure Report

Section: Appendix B

Revision: 0

Date: February 2008

THIS PAGE INTENTIONALLY LEFT BLANK 


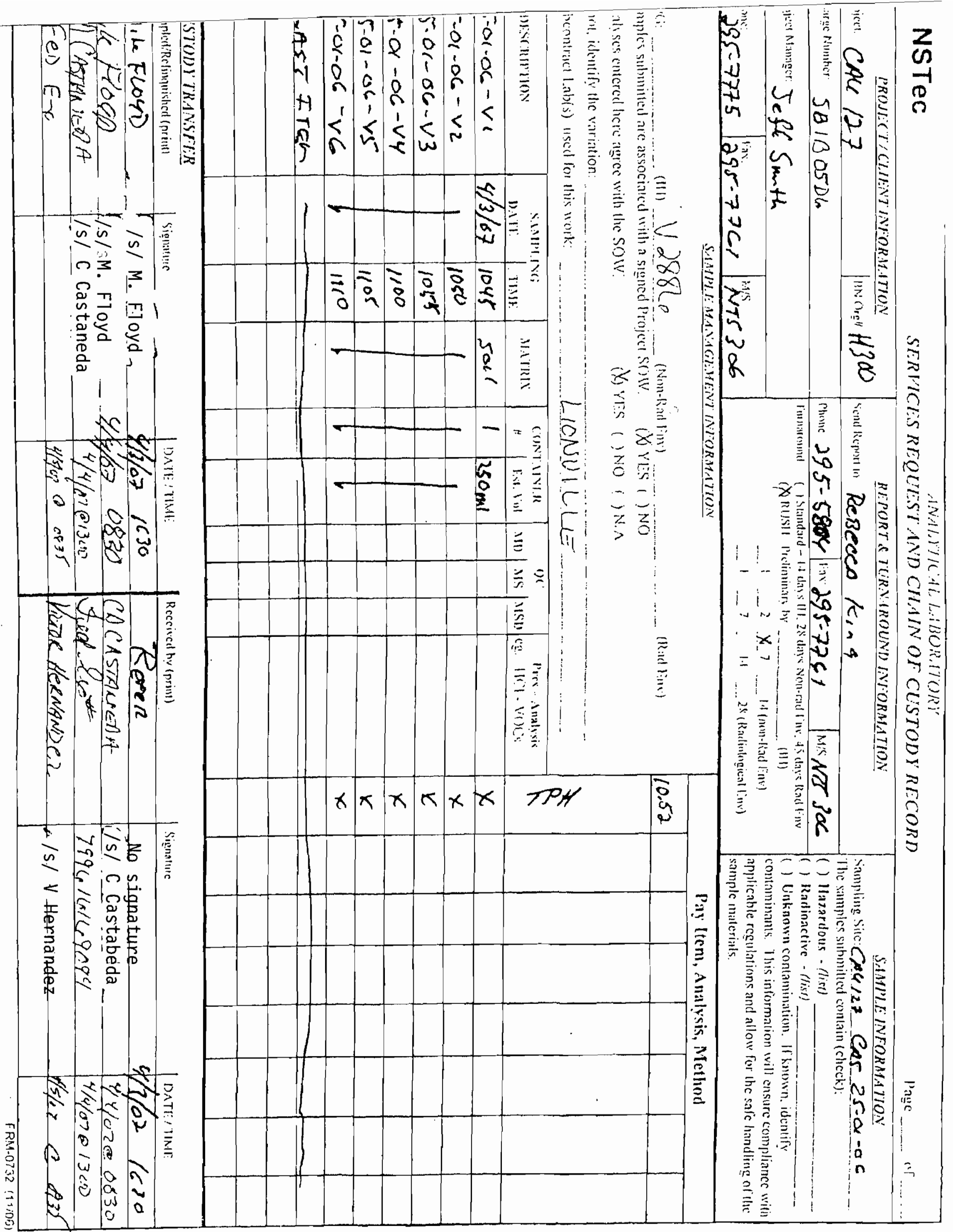




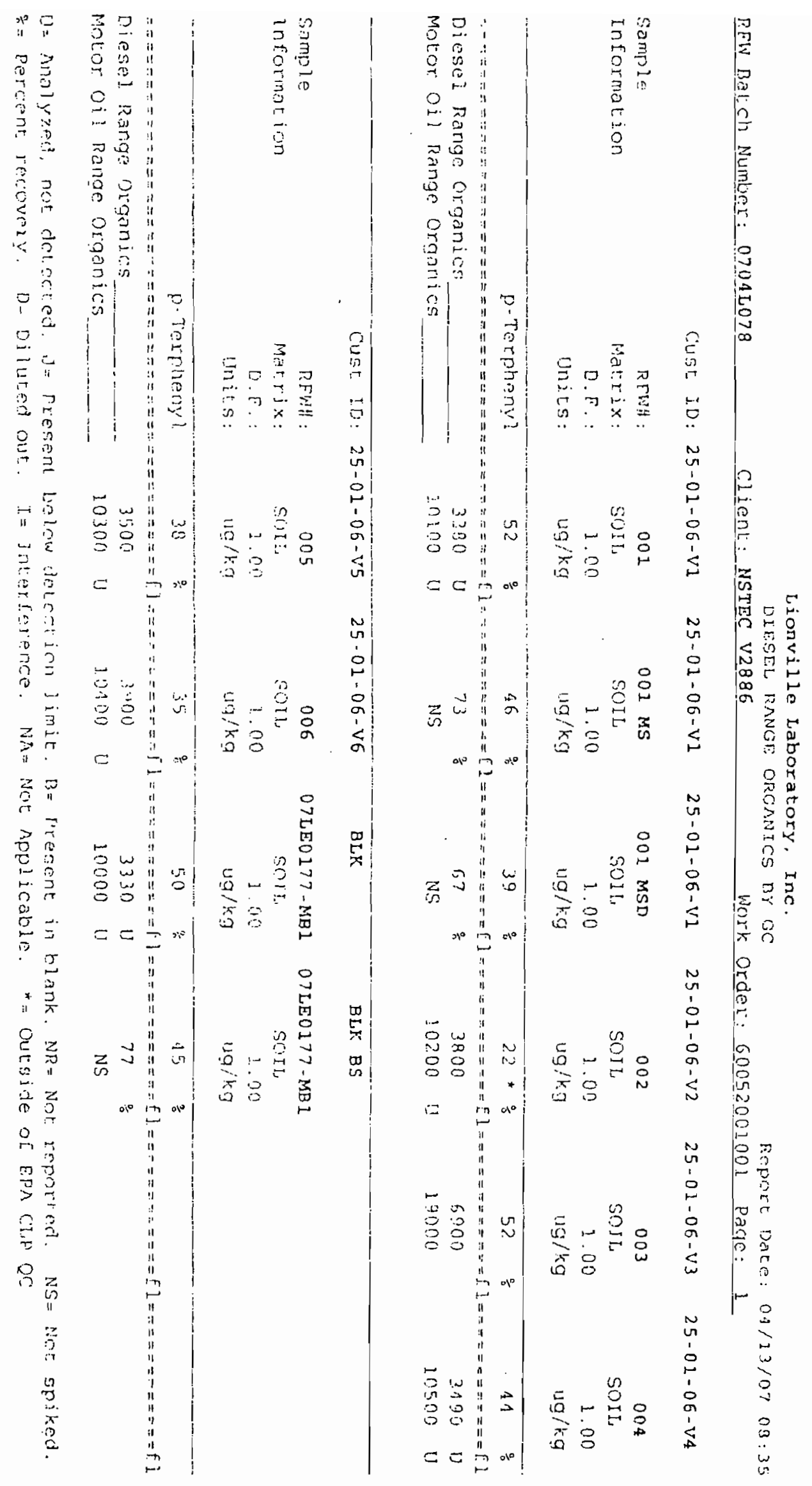




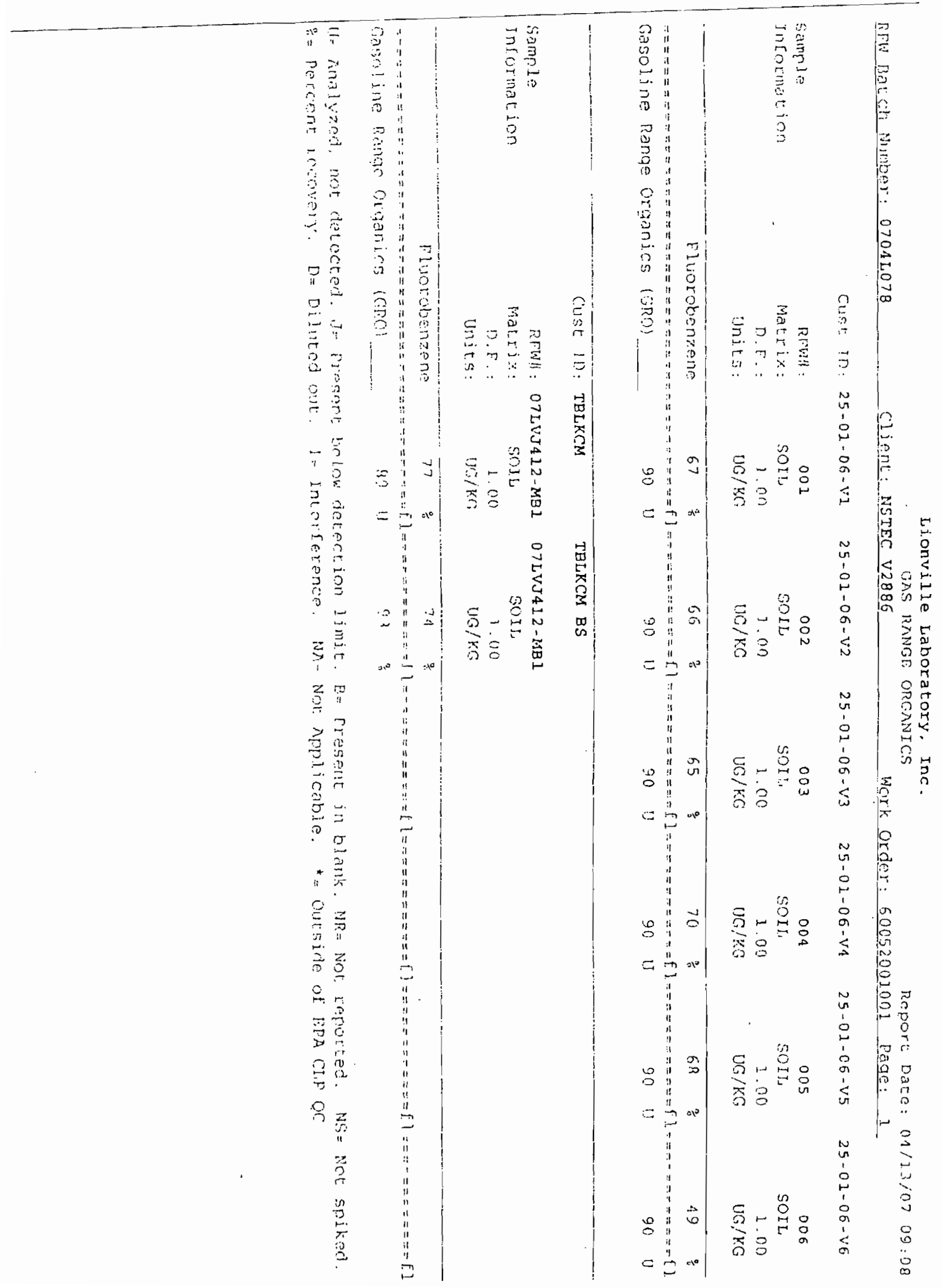




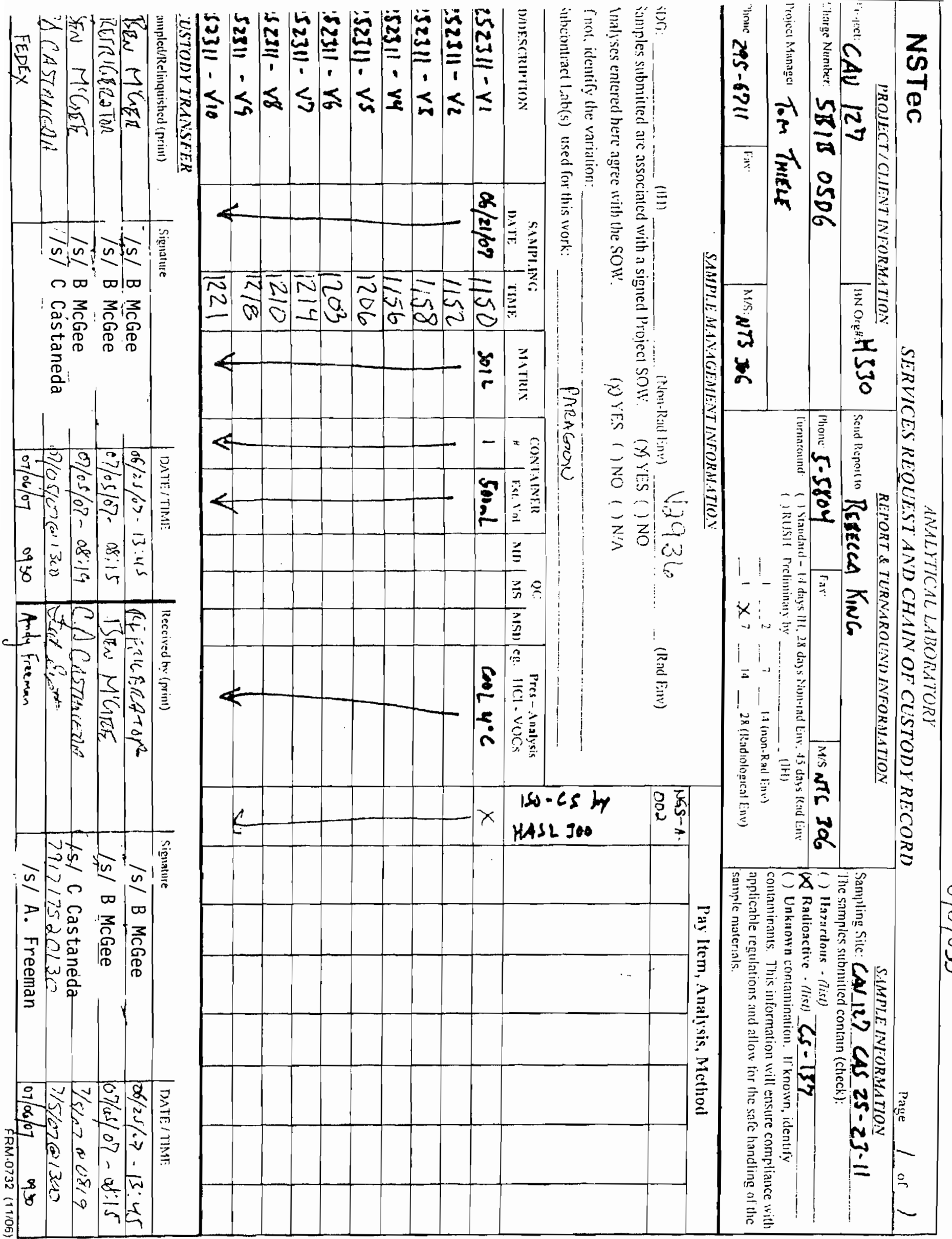




\section{Gamma Spectroscopy Results \\ PAl 713 Rev 9 \\ Sample Results}

Lab Name: Paragon Analytics

Work Order Number: 0707033

Client Name: National Security Technologies, LLC

ClientProject ID: CAU 127 V2936

\begin{tabular}{l} 
Field ID: $252311 . \mathrm{V} 1$ \\
Lab ID: $0707033-1$ \\
\hline
\end{tabular}

Library: L.NG_GAM-A-001

Analysis ReqCode: NGS-A.002
Sample Matrix: SOLL Prep SOP: PAI 739 Rev 8

Date Collected: 21-Jun-07

Date Prepared: 09-Jui-07

Date Analyzed: 09-Jul-07
Prep Batch: GS070707-1

QCBatchID: GS070707-1-1

Run ID: GS070707-1A

Count Time: 30 minules

Report Basis: Dry Weight
Finat Aliquot: $419 \mathrm{~g}$

Prep Basis: Dry Weight

Motsture(\%): NA

Result Units: $p C i / g$

File Name:070971d01

\begin{tabular}{|c|c|c|c|c|}
\hline CASNO & Target Nuclide & Result +1. 2 s TPU & MDC & Lab Qualifier \\
\hline $10045-97-3$ & Cs-137 & $7.32 E-01+i-1.27 E-01$ & $1.01 E-01$ & $1 T, G$ \\
\hline
\end{tabular}

\section{Comments:}

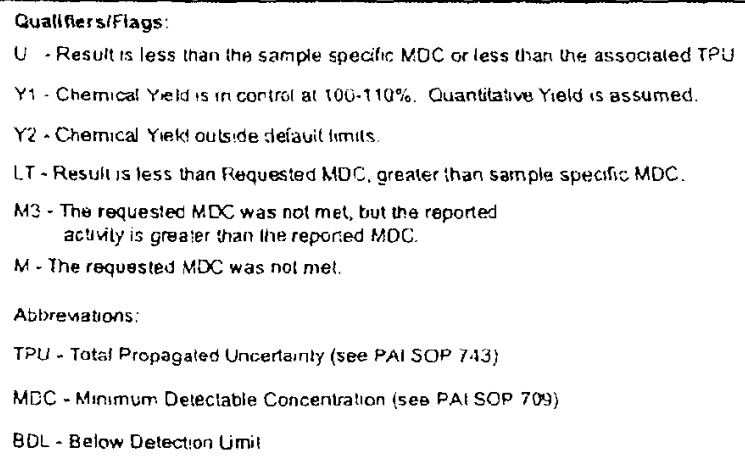

Data Package ID: GSS0707033-1 


\title{
Gamma Spectroscopy Results
}

\author{
PAl 713 Rev 9 \\ Sample Duplicate Results
}

Lab Name: Paragon Analytics

Work Order Number: 0707033

Client Name: National Security Technologies, LLC

CilentProject ID: CAU 127 V2936

Flold ID: $252311-\mathrm{V}$ 1
Lab ID: $0707033-10$ UP

Library: LNG GAM-A-001
Sample Matrix: SOIL

Prep SOP: PAI 739 Rev 8

Date Collected: 21-Jun-07

Date Prepared: 09-Jul-07

Date Analyzed: 09-Jul-07
Prep Batch: GS070707-1

QCBatchlD: GS070707-1-1

Run ID: GS070707-1A

Count Time: 30 minutes

Report Basis: Dry Weight
FInal Aliquot: $419 \mathrm{~g}$

Prep Basis: Dry Weight

Moisture(\%): NA

Result Units: $\mathrm{pCi} / \mathrm{g}$

File Name:070998d02

\begin{tabular}{|c|c|c|c|c|}
\hline CASNO & Target Nuclide & Result +/- 2 s TPU & MDC & Lab Qualifier \\
\hline $10045-97-3$ & Cs-137 & $8.14 E-01+/-1.70 E-01$ & $1.34 E-01$ & $L T, G$ \\
\hline
\end{tabular}

\section{Comments:}

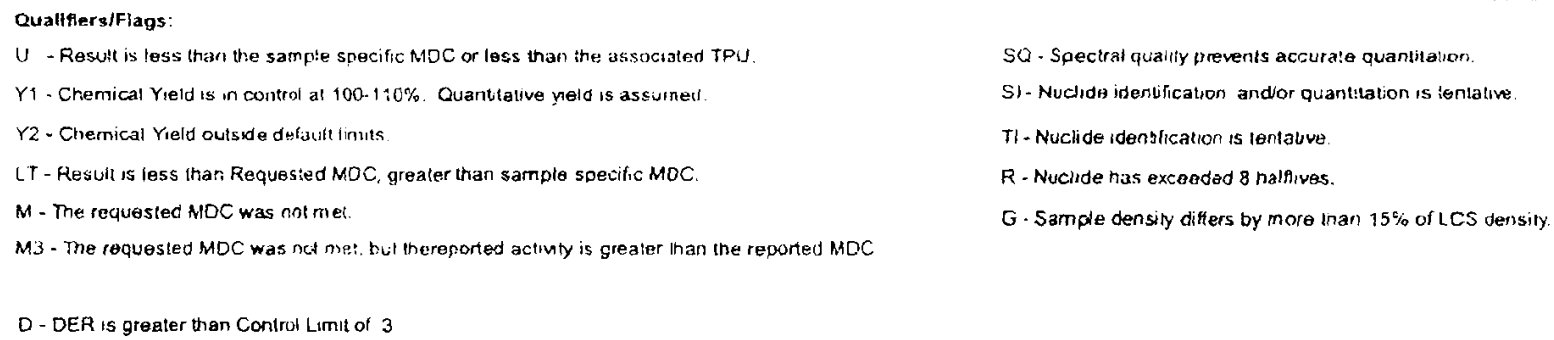

D - DER is greater than Controt Limlt of 3

Abbreviations

TPU - Total Propagaied Uncertainly isee PAI SOP 743)

MDC - Minimum Deleclable Concertration (see PAI SOP 709)

BDL - Below Delection Limit

Data Package ID: GSS0707033-1 


\section{Gamma Spectroscopy Results \\ PAl 713 Rev 9 \\ Sample Results}

Lab Name: Paragon Analytics

Work Order Number: 0707033

Client Name: National Security Technologies, LLC

ClientProject 1D: CAU 127 V2936

Field 10: 252311.V2

Lab 10: $0707033-2$

Library: LNG_GAM-A-001 Aralysis ReqCode: NGS-A-002
Sample Matrix: SOIL

Prep SOP: PAl 739 Rev 8

Date Collected: 21-Jun-07

Date Prepared: 09-Jul-07

Date Analyzed: 09-Jut-07
Prep Batch: GS070707-1

QCBatch1D: GS070707-1-1

Run ID: GS070707-1A

Count Time: 30 minules

Report Basis: Dry Weight
Final Aliquot: $421 \mathrm{~g}$

Prep Basis: Dry Weight

Moisture(\%): NA

Result Units: $\mathrm{pCi} / \mathrm{g}$

Flle Name: 070972d01

\begin{tabular}{|c|c|c|c|c|}
\hline CASNO & Target Nuclide & Result +/- 2 S TPU & MDC & Lab Qualifier \\
\hline $10045-97-3$ & Cs-137 & $3.88 \mathrm{E}-01+1-8.59 \mathrm{E}-02$ & $8.70 \mathrm{E}-02$ & LT,G \\
\hline
\end{tabular}

\section{Comments:}

\begin{tabular}{|c|c|}
\hline \multicolumn{2}{|l|}{ Qualiffer S/Flags: } \\
\hline$U$ - Result is loss than the sample specifc MOC or less than the associated TPU & SO- Spec'sal quality prevents accurale quantitation. \\
\hline Y1. Chemeal Yiald is in control at $100-110 \%$. Ouantitatuve Yietd is assumed. & SI - Nuclide idenuficauon and/or quantitation is lentalive. \\
\hline YZ - Cnermical Yieid ou tside delault limits. & $\pi$ - Nuclide identificavon is sentative. \\
\hline LT. Result is less than Requesled MOC, greater than sarnple specific MOC. & R - Nuchde has exceeded 8 halnives. \\
\hline $\begin{array}{l}\text { Ma - The requested MDC was not met. bul the reporied } \\
\text { are unly is greater than the reported MOC. }\end{array}$ & G. Sample density difters by more than $15 \%$ of LCS density \\
\hline
\end{tabular}

Abbreviations:

TPU - Total Propagated Uncentainty (see PAI SOP 743)

MDC - Minimum Delectable Cuncentravon (se日 PAI SOP 709)

8DL - Below Detechion Lim!

Data Package ID: GSS0707033-1 


\section{Gamma Spectroscopy Results}

\section{PAI 713 Rev 9 \\ Sample Results}

Lab Name: Paragon Analytics

Work Order Number: 0707033

Client Name: National Security Technotogies, LLC

ClientProject ID: CAU 127 V2936

Figld ID: $252311-V 5$
Lab ID: $0707033-5$

Library: LNG_GAM-A-001 Analysis ReqCode: NGS-A-002
Sample Matrix: SOIL

Prep SOP: PAI 739 Rev 8

Date Collected: 21 -Jun-07

Date Prepared: 09-Jui-07

Date Analyzed: 09-Jul-07
Prep Batch: GS070707-1

QCBatchID: GS070707-1-1

Run ID: GS070707-1A

Count Time: 30 minules

Report Basis: Dry Weight
Final Alquot: $438 \mathrm{~g}$

Prep Basis: Dry Weight

Moisture $(\%): N A$

Result Units: $p C \mathrm{~V} g$

File Name: 070975d01

\begin{tabular}{|c|c|c|c|c|}
\hline CASNO & Target Nuclide & Result $+1-2$ s TPU & MDC & Lab Qualifier \\
\hline $10045-97-3$ & Cs 137 & $5.96 E-01+1-1.12 E-01$ & $1.01 E-01$ & $L T$ \\
\hline
\end{tabular}

\section{Comments:}

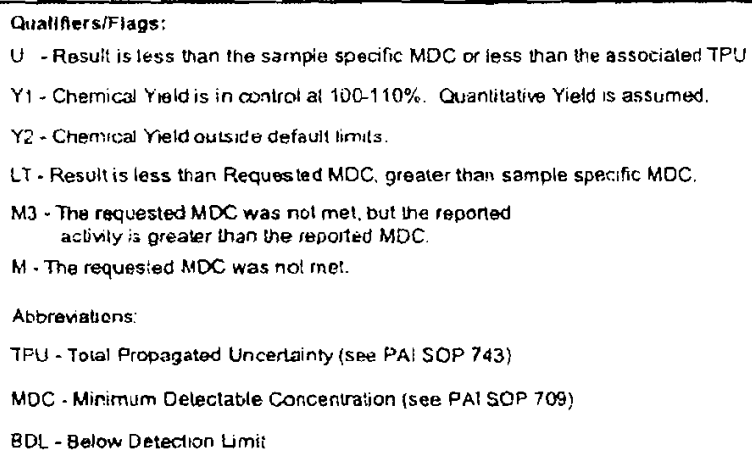

Data Package ID: GS50707033-1
SQ - Spectral quality prevents accurate quantitation.
SI - Nuctide identification and/or quantitaton is tentative.
T1 - Nuctide identification is tentabive
$R$ - Nuchide has excoeded 8 halfives.
G - Sample density differs by more than $15 \%$ of LCS density.

Date Printed: Wednesday, July 18, 2007 


\title{
Gamma Spectroscopy Results
}

\author{
PAl 713 Rev 9
}

Sample Results

Lab Name: Paragon Analytics

Work Order Number: 0707033

Client Name: Nalional Security Technologies, LLC

ClientProject ID: CAU 127 V2936

\begin{tabular}{|c|c|c|c|}
\hline $\begin{array}{l}\text { Fiald ID: } 252311-V 6 \\
\text { Lab ID: } 0707033-6\end{array}$ & $\begin{array}{l}\text { Sample Matrix: SOIL } \\
\text { Prep SOP:PAI } 739 \text { Rev } 8 \\
\text { Date Collected: } 21-J u n-07\end{array}$ & $\begin{array}{l}\text { Prep Batch: GS070707-1 } \\
\text { QCBatchID: GS070707-1-1 } \\
\text { Run ID: GS070707-1A }\end{array}$ & $\begin{array}{l}\text { Final Aliquot: } 431 \mathrm{~g} \\
\text { Prep Basis: Dry Weight } \\
\text { Moisture(\%): NA }\end{array}$ \\
\hline
\end{tabular}

\begin{tabular}{|c|c|c|c|c|}
\hline CASNO & Target Nuclide & Result +1-2 s TPU & MDC & Lab Qualifier \\
\hline $10045-97-3$ & Cs 137 & $6.92 E-01+1-1.20 \mathrm{E}-01$ & $9.44 \mathrm{E}-02$ & LT \\
\hline
\end{tabular}

\section{Comments:}

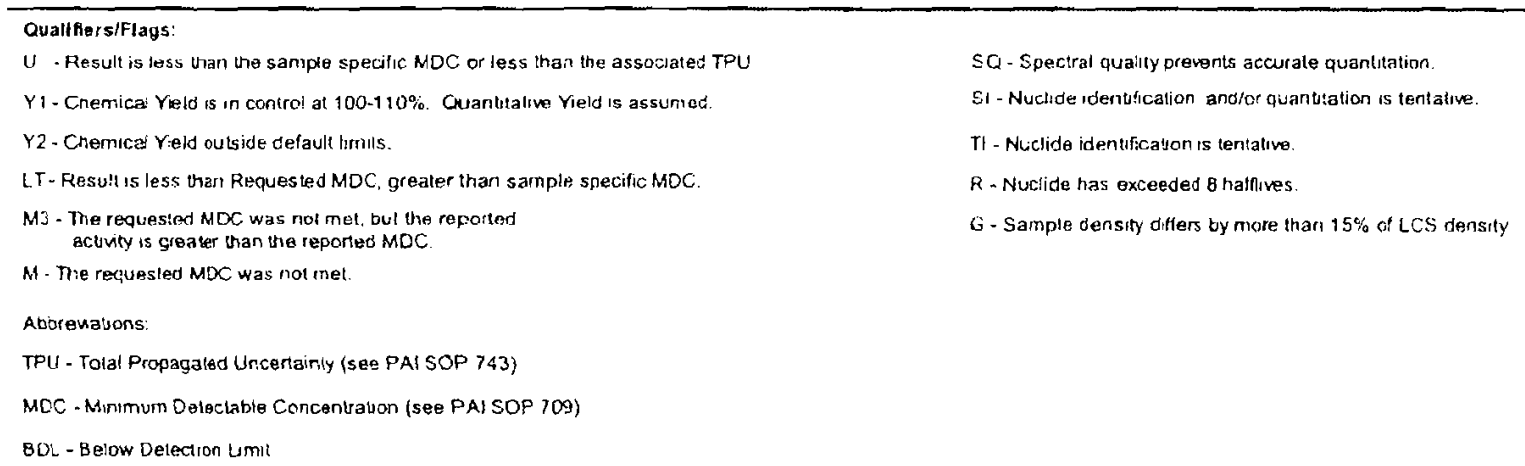

Data Package ID: GSS0707033-1 


\title{
Gamma Spectroscopy Results
}

\author{
PAl 713 Rev 9
}

Sample Results

Lab Name: Paragon Analytics

Work Order Number: 0707033

Client Name: National Security Technologies, LLC

ClientProject ID: CAU 127 V2936

\begin{tabular}{|c|c|c|c|}
\hline $\begin{array}{r}\text { Field ID: } 252311-V 7 \\
\text { Lab ID: } 0707033-7\end{array}$ & $\begin{array}{l}\text { Sample Matrix: SOIL } \\
\quad \text { Prep SOP: PAI } 739 \text { Rev } 8 \\
\text { Dato Collected: } 21 \text {-Jun-07 }\end{array}$ & $\begin{array}{l}\text { Prep Batch: G5070707-1 } \\
\text { QCBatchID: G5070707-1-1 } \\
\text { Run ID: G5070707-1A }\end{array}$ & $\begin{array}{l}\text { Final Aiquot: } 419 \mathrm{~g} \\
\text { Prep Basis: Dry Weight } \\
\text { Moisture(\%): NA }\end{array}$ \\
\hline
\end{tabular}

\begin{tabular}{|c|c|c|c|c|}
\hline CASNO & Target Nuclide & Result +/. 2 s TPU & MDC & Lab Qualifier \\
\hline $10045-97-3$ & Cs-137 & $6.12 E-01+1-1.46 E-01$ & $1.32 E-01$ & L.T.G \\
\hline
\end{tabular}

\section{Comments:}

\section{Qualifiers/Flags}

U. Result is less than the sample specafic MOC or less than the associaled TPU

$Y_{1}$. Chemical $Y_{i}$ id is in controt at $100-110 \%$. Ouantilative Yield is assumed

Y2 - Chemical Yielo outside defaull hm!ls.

LT + Result is less than Fecivestod MOC, greater than sample specific MDC

M3. The requested MDC was not met. but the reported activity is greaier than the reported MOC.

$M$ - The requested MDC was nolmet.

\section{Aborovatons:}

TFU - Tolal Propagaled Uncentanly (seo PAI 5OP 743)

MOC - Minimum Deteclable Concervauon (see PAI SOP 709)

BDL - Below Gelection Limi

Data Package ID: GSS0707033-1
SO - Spectral quatity prevents accurate quanutavon.

St - Nuclide identification and/or quanutation is lentative.

$\mathrm{Tl}$ - Nuclice identification is tentatuva

$R$ - Nuclide has exceded 8 hallives.

G. Sample densily differs by more than $15 \%$ of LCS densiry 


\title{
Gamma Spectroscopy Results
}

\author{
PAI 713 Rev 9 \\ Sample Results
}

Lab Name: Paragon Analytics

Work Order Number: 0707033

Client Name: National Security Technologies, LLC

ClientProject ID: CAU 127 V2936

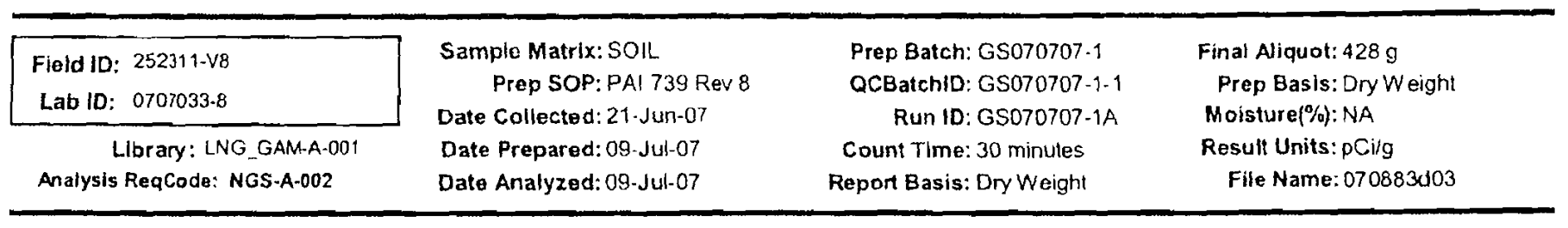

\begin{tabular}{|c|c|c|c|c|}
\hline CASNO & Target Nuclide & Result $+1-2$ s TPU & MDC & Lab Qualifier \\
\hline $10045-97-3$ & Cs-137 & $1.02 E+00+/-1.96 E-01$ & $1.33 E-01$ & \\
\hline
\end{tabular}

\section{Comments:}

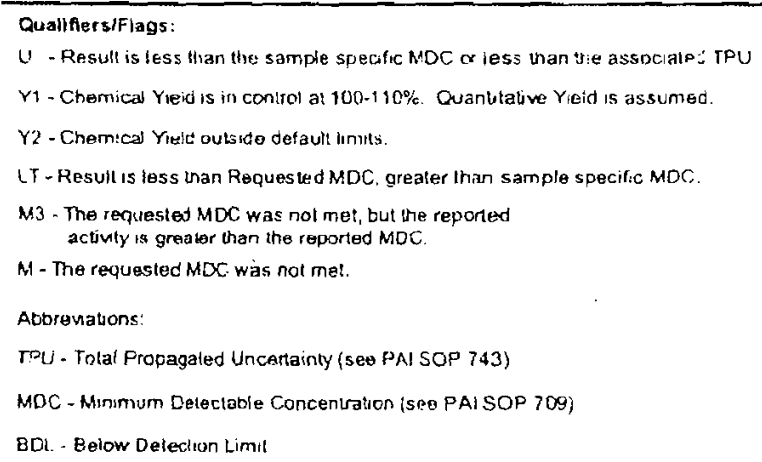




\section{Gamma Spectroscopy Results \\ PAl 713 Rev 9 \\ Sample Results}

Lab Name: Paragon Analytics

Work Order Number: 0707033

Client Name: National Security Technologies, LLC

GlientProject ID: CAU 127 V2936

\begin{tabular}{|c|c|c|c|}
\hline Library: LNG_GAM-A-001 & Date Prepared:09-Jul-07 & Count Time: 30 minutes & Result Units: $p \mathrm{Ci} / \mathrm{g}$ \\
\hline Analysis ReqCode: NGS-A-002 & Date Analyzed: 09-Jul-07 & Report Basis: Dry Weight & File Name:070852d04 \\
\hline
\end{tabular}

\begin{tabular}{|c|c|c|c|c|}
\hline CASNO & Target Nuctide & Result $+/-2$ s TPU & MDC & Lab Qualifier \\
\hline $10045-97-3$ & Cs-137 & $8.69 E+00+1-1.11 E+00$ & $1.52 E-01$ & $G$ \\
\hline
\end{tabular}

\section{Comments:}

Qualifers/Flags:

$U$ - Result is less than the sample speafic MDC or less than t; associated TPU

$Y$ - Chemical Yield :s in control at 100-110\%. Quantitatuve Yield is assumed

Y2. - Chemical Yieid outsice default limits.

LT - Resuit is loss than Requested MDC. greater than sample specific MDC.

M3 - The requested MDC was not the!, but the repored

acuvity is greater than the reproted MOC.

$M$ - The requested $M D C$ was not met.

Abbreviabons:

TPU - Total Propagated Uilcertainty (see PAI SOP 743)

MOC - Minimum Delectable Concentration (See PAI SOD 709)

BOL - Below Deteation Limit

Data Package ID: GSS0707033-1
SQ - Spectral quality prevents accurale quantiation
Si-Nuclide idenufication andior quarthation is tentative.
$T 1$ - Nuclúo identification is lentative
Fi. Nuclico has exceeded 8 halfives.
G - Sample densily differs by more than $15 \%$ of LCS density. 


\section{Gamma Spectroscopy Results \\ PAl 713 Rev 9 \\ Sample Results}

Lab Name: Paragon Analytics

Work Order Number: 0707033

Cllent Name: National Security Technologies, LLC

ClientProject ID: CAU 127 V2936

Field ID: $252311-V 10$
Lab ID: $0707033-10$

Library: LNG_GAM-A-001

Analysis ReqCode: NGS-A-002
Sample Matrix: SOIL

Prep SOP: PAI 739 Rev 8

Date Collected: $21-$ jun-07

Date Prepared: 09-Jul-07

Date Analyzed: 09-Jul-07
Prep Batch: GS070707-1

QCBatchID: GS070707-1-1

Run ID: GS070707-1A

Count Time: 30 minutes

Report Basis: Dry Weight
Final Aliquot: $397 \mathrm{~g}$

Prep Basis: Dry Weight

Moisture(\%) : NA

Result Units: $p C \mathrm{i} g$

File Name: $070981 d 06$

\begin{tabular}{|c|c|c|c|c|}
\hline CASNO & Target Nuclide & Result $+/-2$ s TPU & MDC & Lab Qualifier \\
\hline $10045-97-3$ & Cs-137 & $1.07 E+01+1-1.34 E+00$ & $1.56 E-01$ & $G$ \\
\hline
\end{tabular}

\section{Comments:}

\footnotetext{
Oualifiersiflags:

U. Resull is less than the sample specik MDC cr less than the associated TPU

Y1. Chemicad Yieki is in control at 100-110\%. Ouantilative Yield is assumed.

Y2 - Chemical Yielc outside delisult limils.

LT - Result is less inan Requested WOC, greater than sample specific NOC

A13 - The requesleo MDC was not mat, but the reported

aciuly is greatier than the reported MDC.

M1. The requesled MOC was not met.

Abtroviations:

TPU - Total Propagated Uncerlainty (see PAI SOP 743)

MDC - Mintmum Detectatle Concente ation (see PAI SOP 709 )

BDL - Buluw Delection Limi
}

50 - Speciral quality prevents aceurate quantitation.

Si-Nucide identificalion and/or quantiaton is lentalive.

Data Package ID: GSS0707033-1 


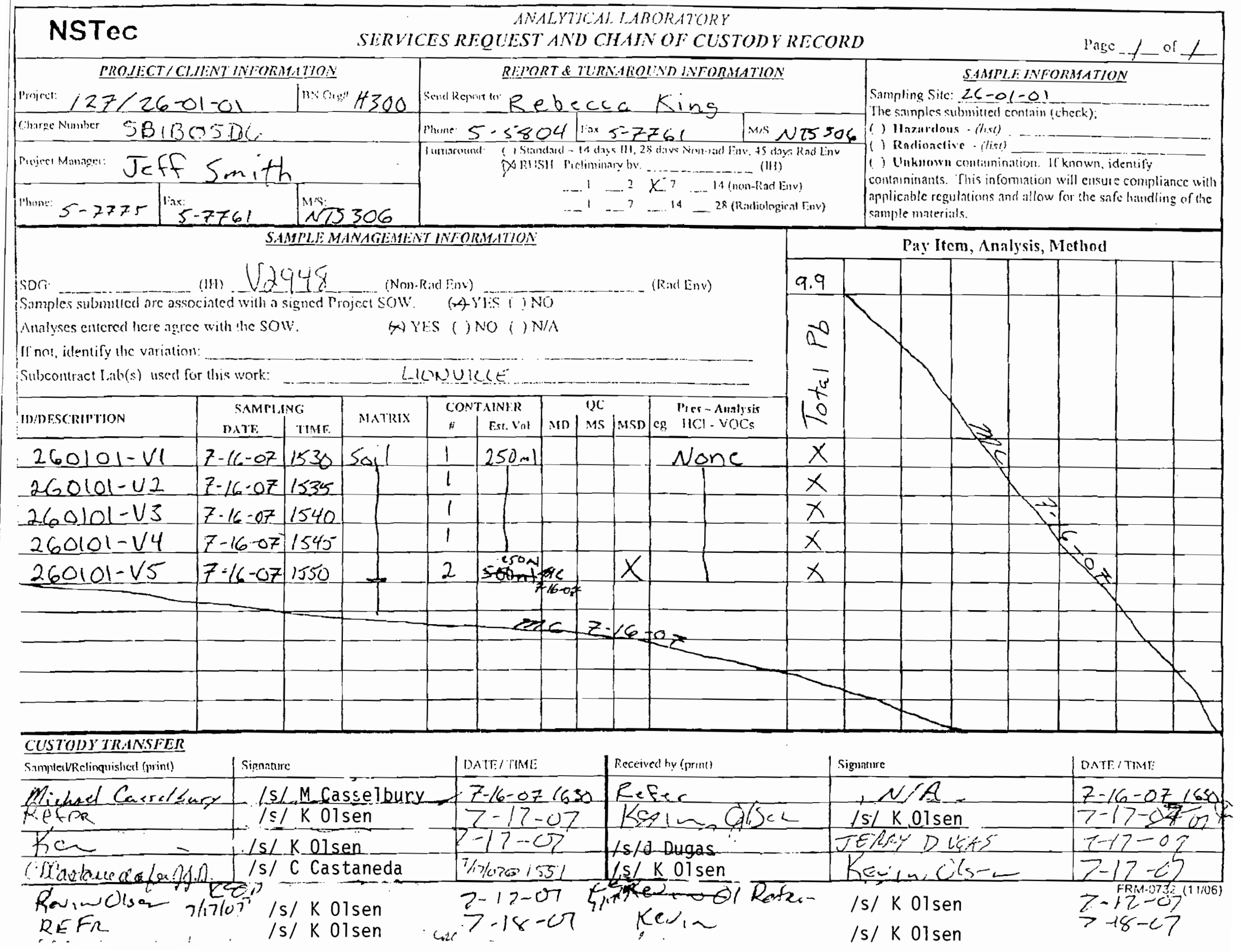


EPA SAMPLE NO.

V1

Contract: 60052

SAS NO.:

Lab Sample ID: 0707L610-0̄0I

Date Received: 07/19/07
Lab Code: LVII Case No.: NSTEC Matrix (soil/water): SOIL Level (low/med): LOW $\%$ Solids:
$-91 . \overline{6}$

Concentration Units (ug/L or $\mathrm{mg} / \mathrm{kg}$ dry weight): MG/KG

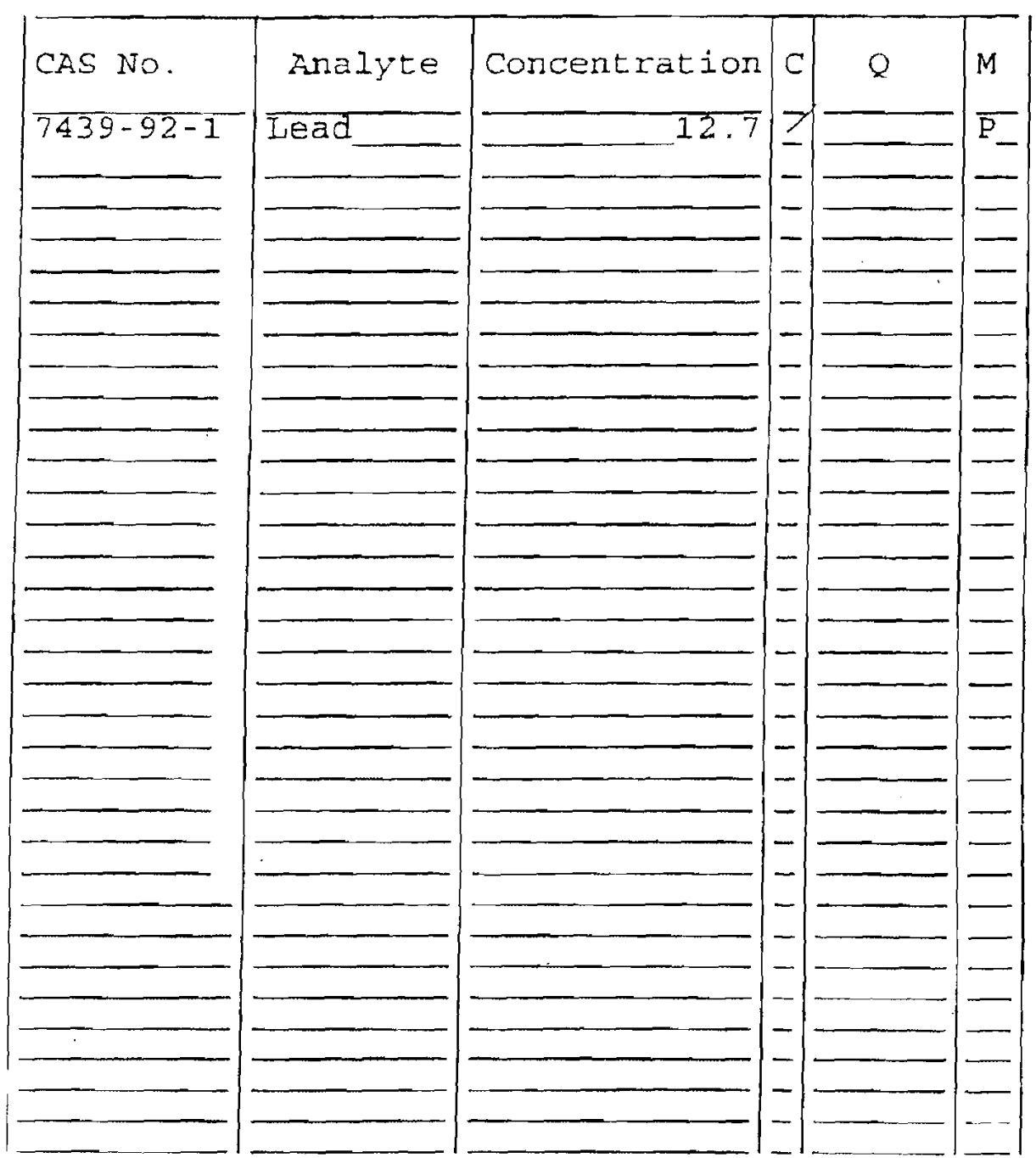

Clarity Before: Clarity After:
Texture:

Artifacts:
Jolor Before: zolor After:

Jomments: 


\section{U.S. EPA}

1

INORGANIC ANALYSES DATA SHEET
EPA SAMPLE NO.

V2

Contract: 60052 SAS NO.:

SDG NO: : V2948

Lab Sample ID: 0707L610-002

Date Received: 07/19/07
Lab Name: LION

Matrix (soil/wat

Level (low

$$
\begin{aligned}
& \text { SOII } \\
& \text { LOW - } \\
& 92.9
\end{aligned}
$$

Case NO.: NSTEC

Concentration Units (ug/L or mg/kg dry weight): MG/KG

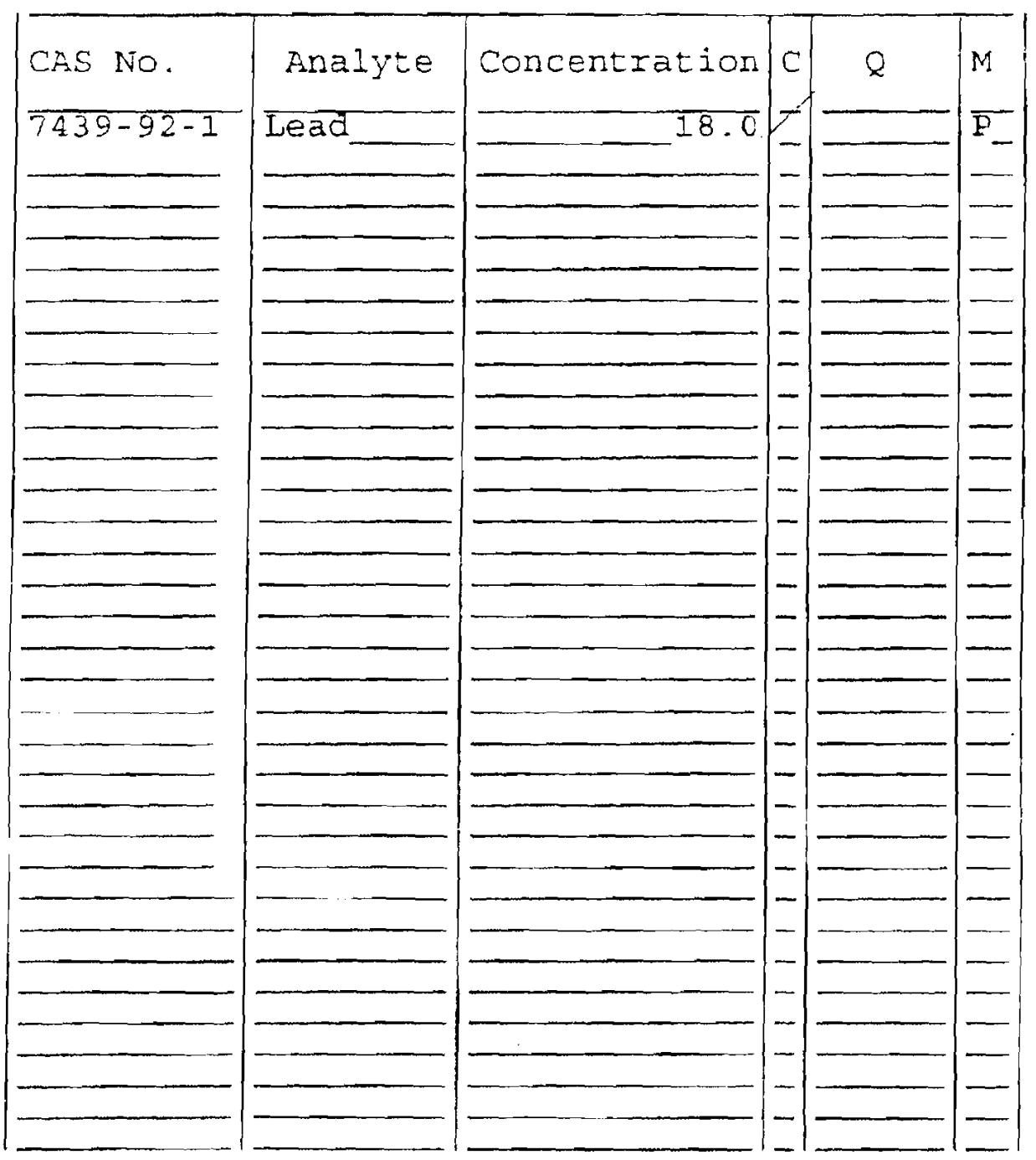

Clarity Before: Clarity After:
310 Before

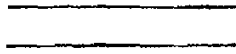

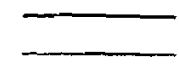

sments:

$260101-\sqrt{2}$
Texture:

Artifacts: 


\section{U.S. EPA}

\section{1 \\ INORGANIC ANALYSES DATA SHEET}

EPA SAMPLE NO.

V3

Contract: 60052

SAS NO.:

Lab Sample ID: $07071610-\overline{0} 03$

Date Received: 07/19/07
Lab Code: LVLI

Matrix (soil/water): SoIL

Level (low/med) :

: Solids:

LOW-

ORATORY

Concentration Units (ug/L or mg/kg dry weight): MG/KG

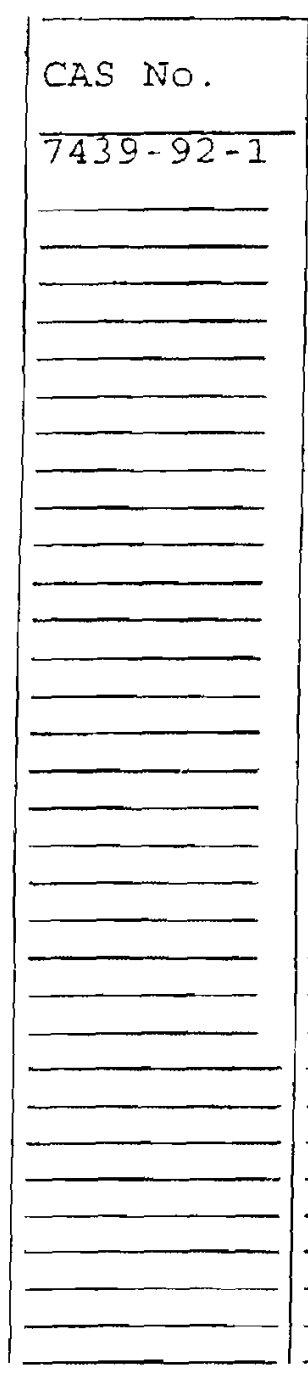

Color Before: Color After:

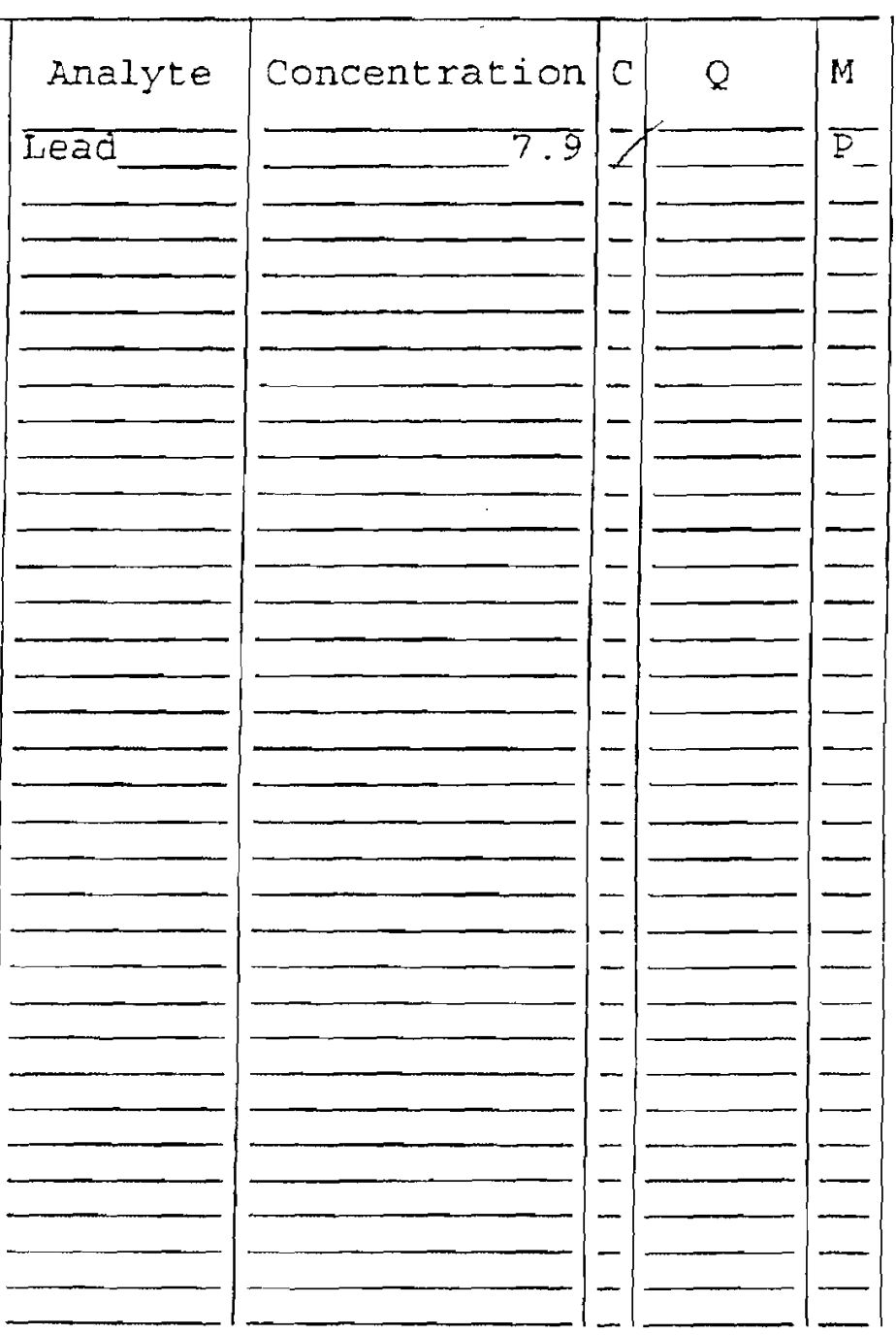

Clarity Before:

Texture:

Artifacts:

Comments :

260101-V3 
CAU 127 Closurc Report

Section: Appendix B

Revision: 0

Datc: February 2008

THIS PAGE INTENTIONALLY LEFT BLANK 
Datc: February 2008

\section{APPENDIX C}

\section{WASTE DISPOSITION DOCUMENTATION}


CAU 127 Closure Report

Scction: Appendix C

Revision: 0

Dalc: February 2008

THIS PAGE INTENTIONALLY LEFT BLANK 


$\begin{array}{ll}\text { NSTeC } \\ \text { Form } \\ \text { FRM-0918 } & \text { NTS LANDFILL LOAD VERIFICATION }\end{array}\left(\begin{array}{r}08 / 23 / 06 \\ \text { Rev. } 0 \\ \text { Page 1 of } 2\end{array}\right.$

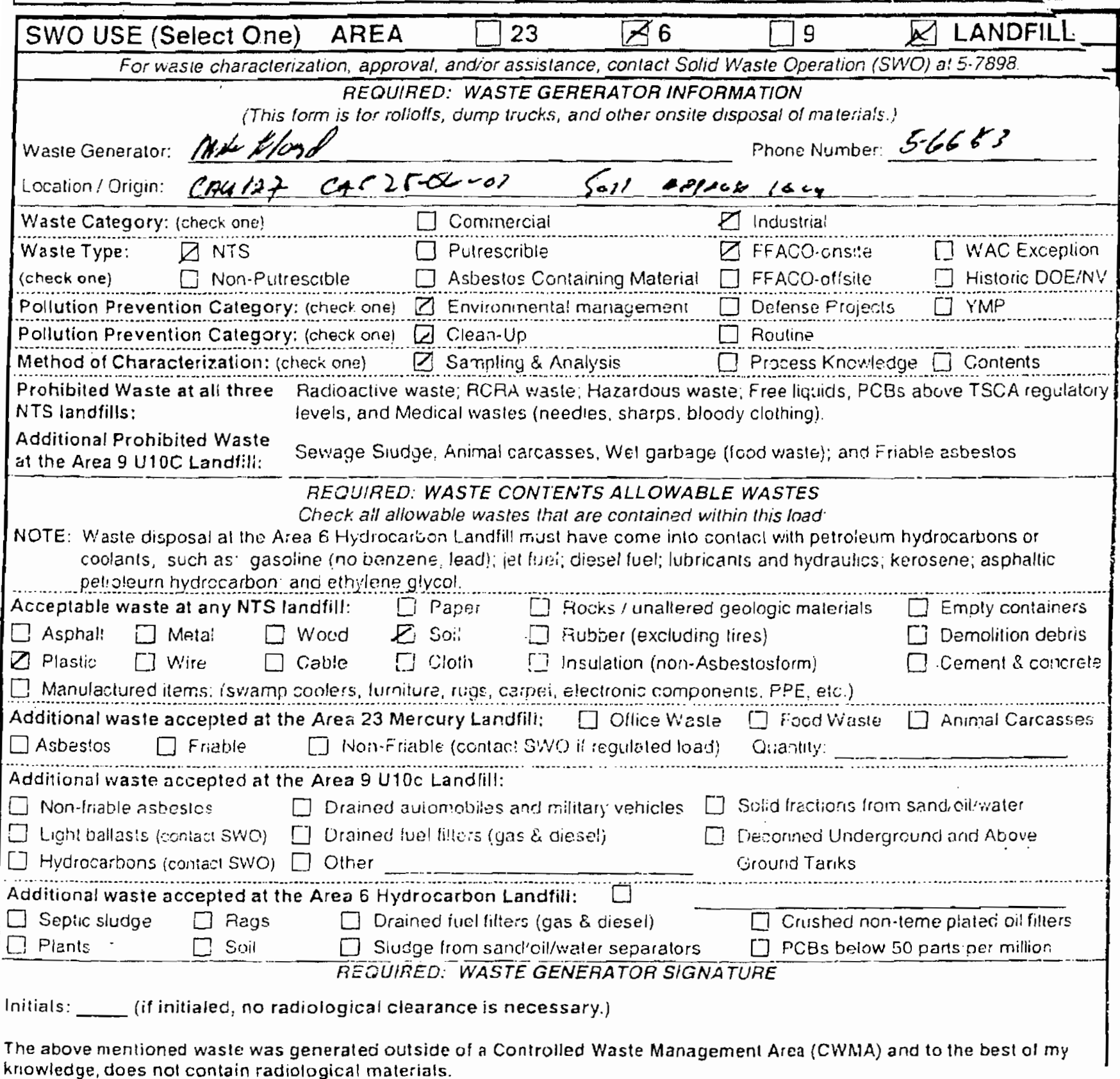

To the besl of my knowledge, the waste described above contains only those mat! sile. I have verified this through the waste characterizalion method identified abo I prohibiled and allowable waste items. I have contacled Property Management anc is approved for disposal in the landfill.

Prin: Name:

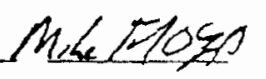

Signalure: LS/ M Floyd
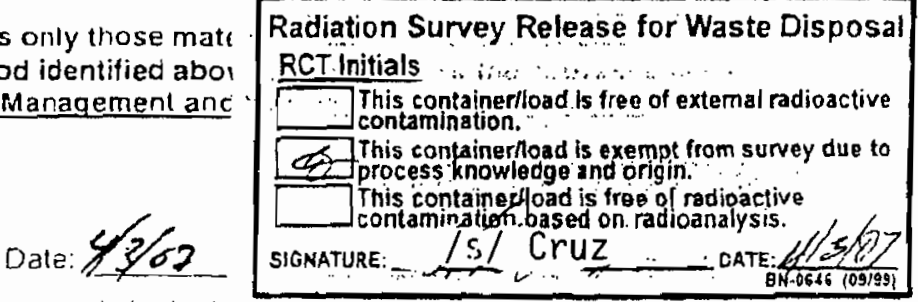

Nole: "Food waste, office trash and animai carcasses do nol iequire a radiological must have signed temoval certlication slatement with Load verification."

SWO USE ONLY

Load Weigh: (net trom scale o! esimate). $4 \begin{gathered}4-3-07 \\ 4\end{gathered}$

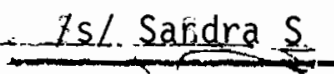




\begin{tabular}{|l|llll}
\hline SWO USE (Select One) AREA & $\square 23$ & Z6 & $\square 9$ & L LANDFILL
\end{tabular}

For waste characlerization, approval, and/or assislance, contacl Solid Wasle Operation (SWO) al 5.7898

$$
\text { REOUIRED: WASTE GERERATOA INFORMATION }
$$

(This form is for rolloffs, dump trucks, and ollher onsite disposal of malerials.;

\begin{tabular}{|c|c|c|}
\hline \multirow{2}{*}{\multicolumn{3}{|c|}{ 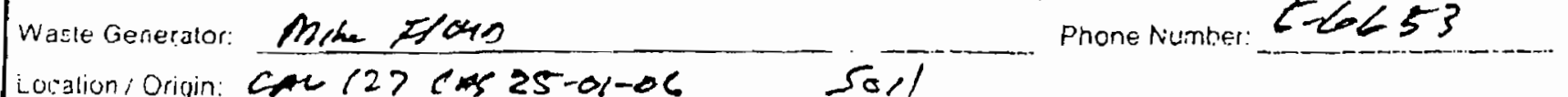 }} \\
\hline & $\operatorname{coc} 127 \cos 25-01-06$ & \\
\hline Waste Category: (check one) & [ Commercial & $\$$ irdustrial \\
\hline Waste Type: & $\square$ Putrescrible & [ WRAO Excrplion \\
\hline (check one) & $\square$ Astestos Containing Material & $\square$ FFACO.Onsile \\
\hline \multicolumn{2}{|c|}{ Pollution Prevention Category: (check one! X Environmental managernent } & D Delense Projects \\
\hline \multirow{2}{*}{\multicolumn{2}{|c|}{$\begin{array}{l}\text { Pollution Prevention Category: (check one) } \varnothing \overline{\text { Clean-Up }} \\
\text { Meihod of Characterization: (check one) }\end{array}$}} & $\square$ Routine \\
\hline & & 7 Process \\
\hline
\end{tabular}

Meihod of Characterization: (check one) \& Sampling \& Aralysio $\square$ Process Knowiedge $\square$ Conlenls

Prohibited Waste al all three Radioaclive wasle; RCFA wasle, flazardous waste. Free liquids, PCBS above TSCA regulalory NTS landfills:

Additional Prohibited Waste

at the Area 9 U10C Landfill: levels, and Medical wasles (needies, sharps, bloody clothing).

Sewage Siudge. Anmal carcasses, We! garcage (lood waste): and Friable asbestos

\section{REQUIRED: WASTE CONTENTS ALLOWABELE WASTES}

Check all allowable wisles that are contained within this load

NCITE: Viaste disposai al the Area 6 Hydrocarton Landfill musi have come into contact with pelroleum hydrocartons or coolanks. such as: gasoline (no benzene, lead!: je! luei; diesel fue;; lubricants and hydraulics; kerosene; zsphait": retroieurn nydrocarbon; and elnyleng glycul.

Acomaptable waste at ariy NTS landfill: $\square$ Paper.

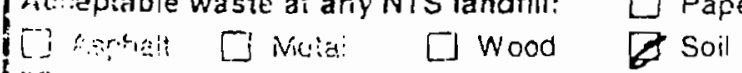

Lasio [J Vire

[] Cable

$\square$ Cloh

Dicicks, uniliered geologic inderials

[] Emoti' coribiners

[ Fiuboe: isxcludirg tires)

$\square$ Uemolition ciebris

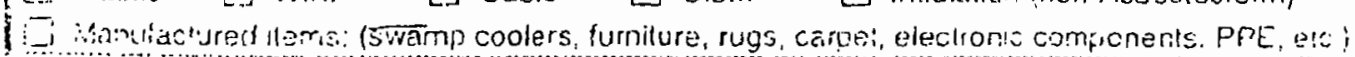

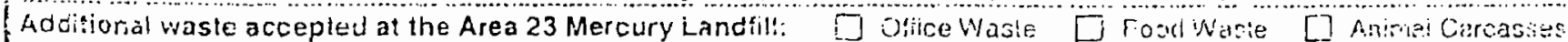

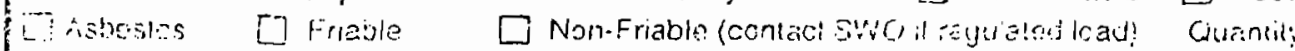

\section{Airditiorial vasie accepled at the Area 9 U10e Londfilt:}

Worlinable ackiciostos

$\square$ biained culorinotibes and niitary vetules

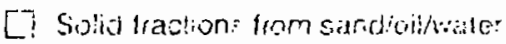

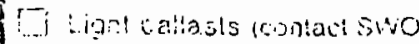

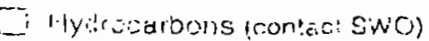

IJ braired tue: filte: 3 (yas \& clieseli Other

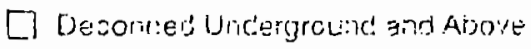
Ground Tanks

Aclditional waste nccepted at the Area 6 Hydrocarbon Landfili:
[I) Seplic sludge $\square$ Rags
li: Pi:nis
$\square$ Soil
$\square$ Draned fuel fillers (gas \& diesel)
$\square$ Crushed non-ieme plated oil filiers
$\square$ Sludge from sandioil water separaiors

REQUIRED: WASTE GENERATOR SIGNATURE

Irilials: ___ (it initia!ed, no radiological clearance is necessary.)

The above menlioneci waste was yenerated outside of a Controlleo Waste Management Area (CWMA) and to the besi o' rn; knowledge, does not contain radiologícal materials.

To the best of my knowledge, the waste described above contains only those materi site. I have verified this through the waste characterization method identified above prohibited and allowable waste items. I have contacted Propeny Management and $r$ is approved for disposal in the landfill.

Prinl Name:

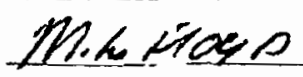

Signature: LS/ M Floyd
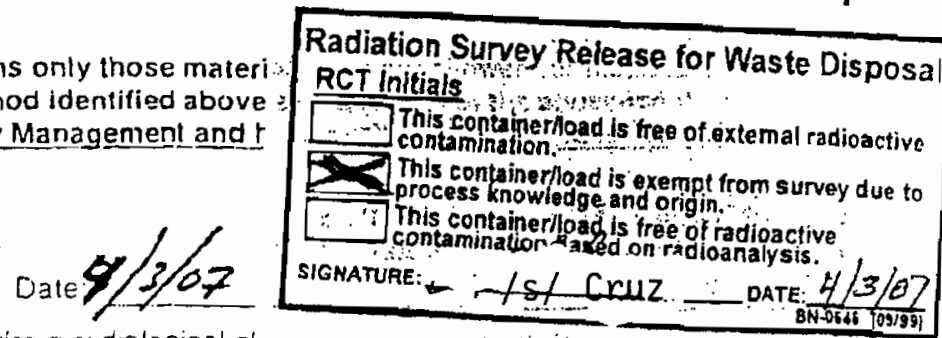

Nole: "Food waste, olfice trash and animal carcasses do nol require a rifdolegioal must have signed removal certification slatement with Load Verification."

SWO USE ONLY

Loic Weight (rel from scale or estimale):

$4 \cdot 3-47$

Signelure of Certifier:

/s/ see original 
NSTec

Form

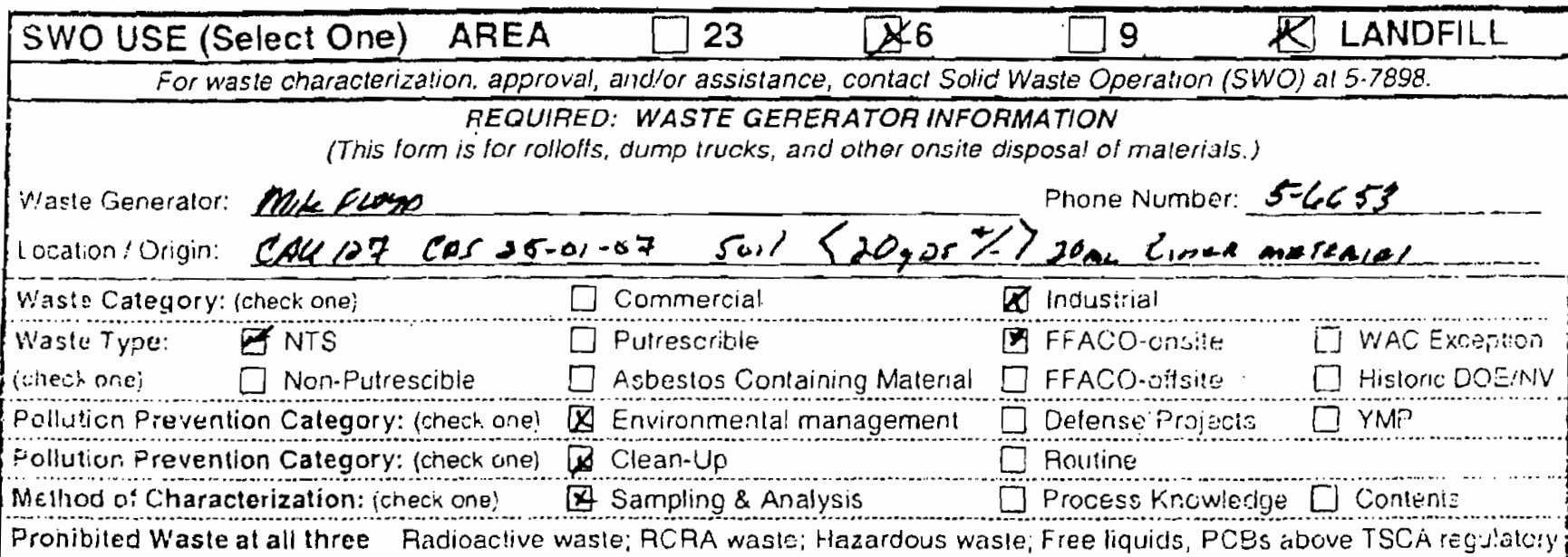

MTS landfills:

isdilional Prohibited Waste

A: tict Area 9 UtoC Landfill:

\section{REOUIRED: WASTE CONTENTS ALLOWABLE WASTES}

Check all allowable wastes that are contained within this load

Nerle: Viaste disposal ai the Area 6 Hydrocarbon Landfll musl have come into conlacl with petroleum hydrocaituons or roolarls, such as: gasoline (no benzene, lead); jet fuel; diesel fuel; lubricants and hydrautics; kercisene; asphalt!c bet foleum hydrocarbon; and ethylene glycol.

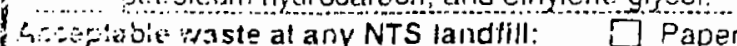

Q 7 in: $\square$ Metai $\square$ Wood

[F Soii

$\square$ Rocks / unallered geologic materials

I] Empiy sontainars

U istin:

$\square$ Meta

[Wooú

$\square$ Cloth

[] Rubber (excluding tires)

$\square$ Insulation (non-Asbestosiorm)

$[$ Demolutitr, deb!s

12 Pisis

Cable

arpel,

eicclronic compenents, PPE. Elc.)

Adsilion:a: waste accepted at the Area 23 Mercury Landfill: $\square$ Ofhico Wasle $\square$ Food Waste

Cl rement y curciate

[J Asbusces [] Friable $\square$ Non-Friable (conlaci Swo il regulated load) Cuantil:

Addisisan! raste aceepted a: the Area $\$$ Uioc Landfil:
[? ivon-ireble asheslos
[.] Drained automobiles and military vehicles

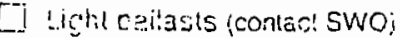
[1 Drained fuel fillers (gas \& diesel)
$\square$ Solid Ractions lrumi sandoblthiliei
[Z Hidraciarons (contacl SwO) [] Other
I Uecomed Undergiound arud Above Ground Tanks

Additianal vaste accepted at the Area 6 Hydrocarbon Landfill:
$\square$ Sepic siudge
$\square$ Rags
$\square$ Drained fuel filters igas \& diesel)
[.. Plami:
$\square$ Soil
$\square$ Sludge from sandioil/water separalors
$\square$ Crushea nori-leme plated oil tilie:s REDUIRED: WASTE GENERATOR SIGNATURE
$\square$ PCBs below 50 parts pe: rnii iori

Inirials: (if initialed, no radiological clearance is necessary.)

Tise above mentioned waste was generated outside of a Controlled Waste Management Area (CWMA) and to the best of $\mathrm{my}$

knowléf ye does not contain radiological materials.

io the bes! of my knowledge, the wasle described above contains only those materials that are allowed for disposal at this sitc. I have verified this through the waste characterization method identified above and a review of the aha.......... frohibited and allowable waste items. I have conlacted Property Management ar.. is approved for disposal in the landfiil.

\section{Prini Name: Mkk Fleyo}

Sigimature: $\quad$ /S/M Floyd

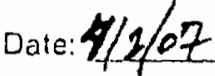

Nole: "Food wasle oflice trasi and animal carcasses do nol require a radiological inus! have signed removal certification stalement with Load Ve rilication."

\section{SWO USE ONLY}

Load Weight (net from scale or estimale): I1 80

$4-2-07$

Signalure of Certifier:

Radiation Survey Release for Waste Disposal RCT Initials

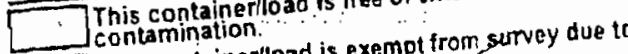
This containerlload is exempt trom process knowledge and origin. This containerload is free oftadioactys contamination baspond

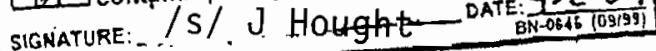
/s/ See Original 


\begin{tabular}{|llllll}
\hline SWO USE (Select One) AREA $\square 23$ & $\square 6$ & 9 9 & 区 LANDFILL
\end{tabular}

For waste characlerization, approval, and/or assistance, contaci Solid Waste Operation (SWO) at 5-7898

REOUIRED: WASTE GERERATOR INFORMATION

(This form is for rollolls, dump trucks, and other onsile disposal of materials.)

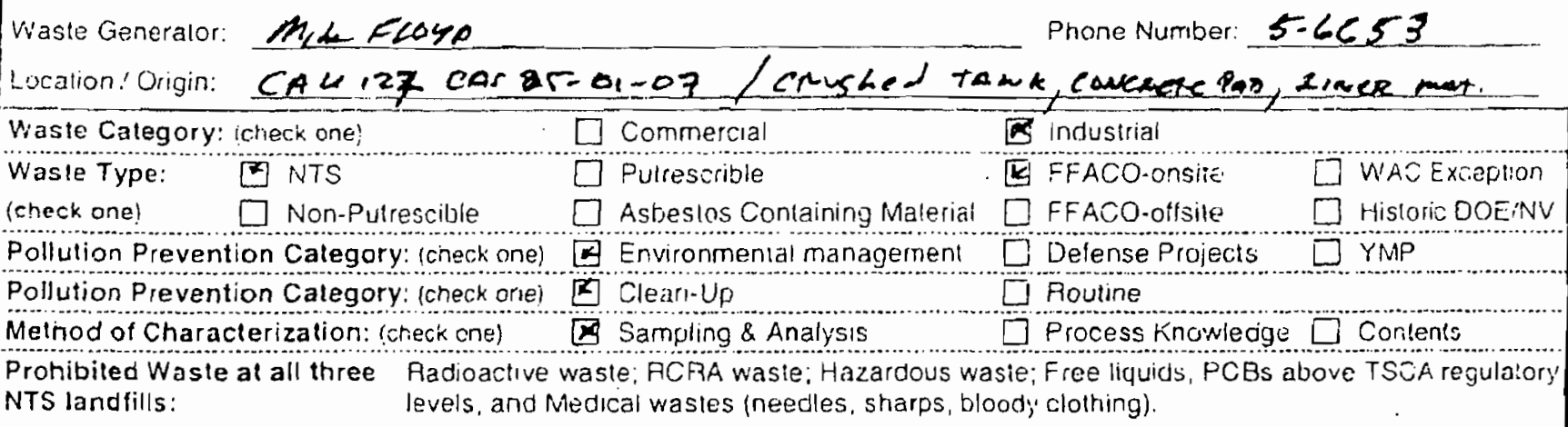

Additional Prohibited Waste at the Area 9 U10C Landfill

Sewage Sludge. Anmal carcasses, Wel garbage (lood wasle); and Friable ashesios

\section{REOLIRED: WASTE CONTENTS ALLOWABLE WASTES}

Check all allowable wastes that are contained within this load

NOTE: Wasle disposal at the Area 6 Hydrocarbon Landfill must have come into contacl with peiroleum hydrocarbons or coolants, such as: gasoline (no benzene, lead; jet fuel, diesel luel; luoricants and hydraulics; kerosene; asphaltic petroleum hydrocarbon: and e!hy!ene glycol.
Acceptable waste at any NTS landfili
$\square$ Pape:
[] Rocks, unaltered geoiogic materials
Emply conlainers
$\square$ Asphall $\square$ Metal $\square$ wood
$\checkmark$ Soil
[ Fubber (excluoing tires)
[] Demolituon debris
[A Plastic $\square$ Wire
Cable
$\square$ Clon
[a] Insulation (non-Asbestostorm)
Len Ceneni \& conciele

I. Manulecluren itens: (swamp coolers, furniure. rugs, carpet, ciecticric components. PPE. efo.)

Additionat waste accepted at the Area 23 Mercur; Landfil: [] Ollice Wasto [] Food Waste $\square$ Aminal Carcasses
IJ Asbeslos
$\square$ Friable
$\square$ Nonfriable comaci swo ii regulateriloant
Cuantily

Additional waste accepled at the Area 9 U106: Landfill
$\square$ Non-frialy!e asbes!os
$\square$ Drained culomcbiles anci military vehicles
[1] Scilatraclions from sandionlinater

$\square$ Lighil ballasts iconta: SWD;

1] Crained fuel lilers (gas \& diesel)

1] Deconned Underground and Above

[I Hydrocarbons (conlaci svio:

Other Ground Tarks
Additional waste accepted at the Area 6 Hydrocarbon Landfili:
$\square$ Sephic sludge
$\square$ Rags
$\square$ Orained luel fitters (gas \& diesel)
$\square$ Crushed non-teme plated ail filters
D plants
Soil
$\square$ Sludige from sandioiliwater separators REOUIREO: WASTE GENERATOR SIGNATURE

Initials: (if initialed, no radiological clearance is necessary.)

The above mentioned waste was generated outside of a Controlled Waste Management Area (CWMA) and to the best of my

knowledge, does not contain radiological materials.

To the best of my knowledge, the wa ste described above contains only those materials that are allowed for disposal at this site. I have verified this through the waste characterization method identitied aboi prohibited and allowable waste items. I have contacted Property Management and is approved lor disposal in the landfill.

Prinl Name: Mike Fleys

Signature. -ls/ MEloyd Date: $3 / 29107$

Note: "Food wasle, oftice trash and anima! carcasses do not require a radiological mus! have signed removal certification statement with Lciad Verilication."

SWO USE ONLY

Load Weight (nel lrom (scale or sstimate) $\not C D$ signature of Cerilier:
Radiation Survey Release for Waste Disposal RCT. Initials

This container/load is free of external radioactive contamination.

This containerlogo is exempt from survey due to process knowledge and oricin.

This container/lo od is tree of radioative This container/load is free of radioactive

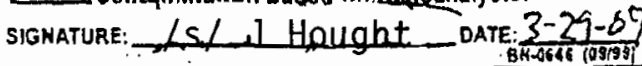


NSTEC

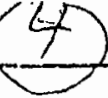

Form

FRM-0918

NTS LANDFILL LOAD VERIFICATIONS

AREA

\begin{tabular}{|lllllll}
\hline SWO USE (Select One) & AREA & $\square 23$ & $\square 6$ & 79 & $\square$ & LANDFILL
\end{tabular}

$\square 6$

79

Page 1 of 2

For waste characlerization, approval, andior assistance, contact Solid Waste Operation (SWO) at 5-7898.

REOUIAED: WASTE GERERATOR INFORMATION

(This form is for rollotfs, dump trucks, and other onsile disposal of materiais.)

Waste Generator:
Localion / Origin:

Mik Feoyn

Phone Number: $5 \cdot 4 \mathrm{C} 5$

Waste Calegory: (check one)

Waste Type: 因 NTS

(check one)

[] Non-Pulrescible

$2 r=01-0.6$ crustar tant

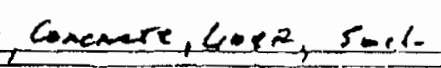

$\square$ Commercial $[\vec{B}$ industral

$\square$ Puliescrible D FFACO-onsite

$\square$ Asbestos Conlaining Material

D FFACO-onsite

Pollution Prevention Category: (cneck one) [z] Environmentai management

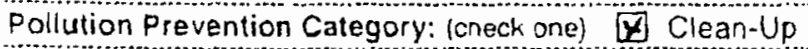

[7. Sampling \& Analysis

$\square$ Delense Projecls

Routine

Frohibited Waste at all three

NTS landfills:

Additional Prohibited Waste

at the Area 9 U1OC Landfill:

Padioaclive waste; RCRA waste; Hazardous wasle; Free liquids PCBs above TSCA regulétory

levels, and Medical wastes (needles, sharps, bloody clothing).

Sewage Sludge, Animal carcasses, Wel garbaue (iood waslej: and Friable asibstos

\section{REOUIRED: WASTE CONTENTS ALLOWABLE WASTES}

Check all allowable wastes that are conianled within this load:

NOTE: W/asle disposal al the Area 6 Hydrocarbon Landfill mus! have come inlo con last wili; pelroleum hydrocarbons or coolants, such as; gasoline (no benzene, lead); jet fuel; diesel fuel; iubric anti and rydraulics; kerosene; asphaitic pelroleum hydrocarbon and elryiene glycol

Acceptaule waste al any NTS landfill: $\square$ Paper $\square$ Focks / unallered geologí maleria!s $\square$ Fripty conlainers

T Asphalt $\square$ Melat $\square$ Wood

P Plés!ic $\square$ Wire $\square$ Cable $\square$ Cloth

$\square$ Fiubber (excluding tires)

$\square$ Insulation inon. Asterstosíomi

$\square$ Demolltim debris

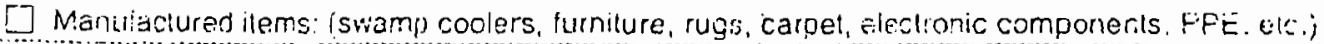

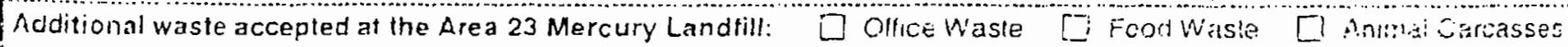
[.] Asbesios
$\square$ Frtabie
$\square$ Non-Friable (contact SwO ii regulated load)
Ouanilly.

Niditional waste accepled at the Area 9 U10c Landill:
I. Non-filable asbestos
$[$ Drained automobiles and military vetucies
Soild flactions from sandioilivater
$\square$ Light cailests (conlact SwO)
$\square$ Drained luel filters (gas \& die:el)
[] Decomed ilniderground and Aonve
$\square$ Hysrocarbons (contacr Sw/O)
Other Ground Tanks

Additional waste accepted at the Area 6 Hydrocarbon Landfill:

$\square$ Sephic sludge $\square$ Rags $\square$ Drained fuel filiers (gas \& diesel)
$\square$ Plarils

initials: (if initialed, no radiological clearance is necessary.)

The above mentioned wasle was generated outside of a Controlled Waste Management Area (CWMA) and to the best of my knowledge, does nol contain radiological materials.

To the best of my knowledge, the waste described above contains only those malerials that are allowed for disposal at this sile. I have verified this through the wasle characterization method identified abc prohibited and allowable waste items. I have contacted Property Management an is approved for disposal in the landfill.

Prin! Name: $\lambda_{1} \&$ KLoy

Signature: $/ s / M$ Floyd Date: $3 / 28<07$

ivole: "Food wasle, oftice trash and animal carcasses do nol require a radiological mus! have signed removal certification statement with Loag Verificalion."

SWO USE ONLY

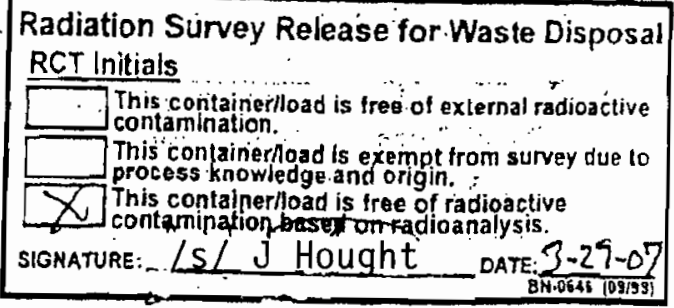

in' 
P|case ; pini or lype (Forn oesioned lo use on elite (12-puch) (yoewriter.)

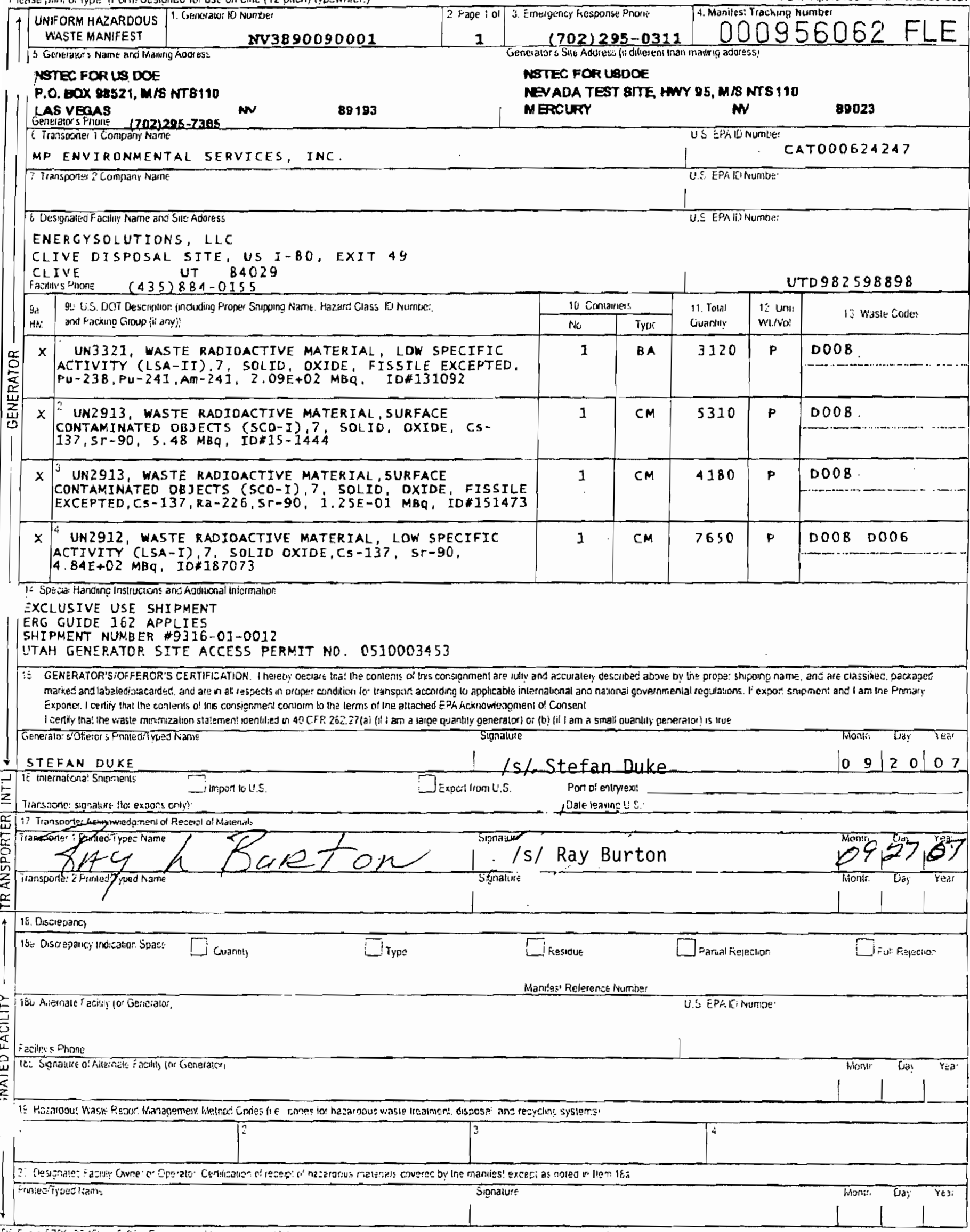


east grint o: type. (Form desioned ior use on elite ( $i z$ pilch) (yoswiler.)

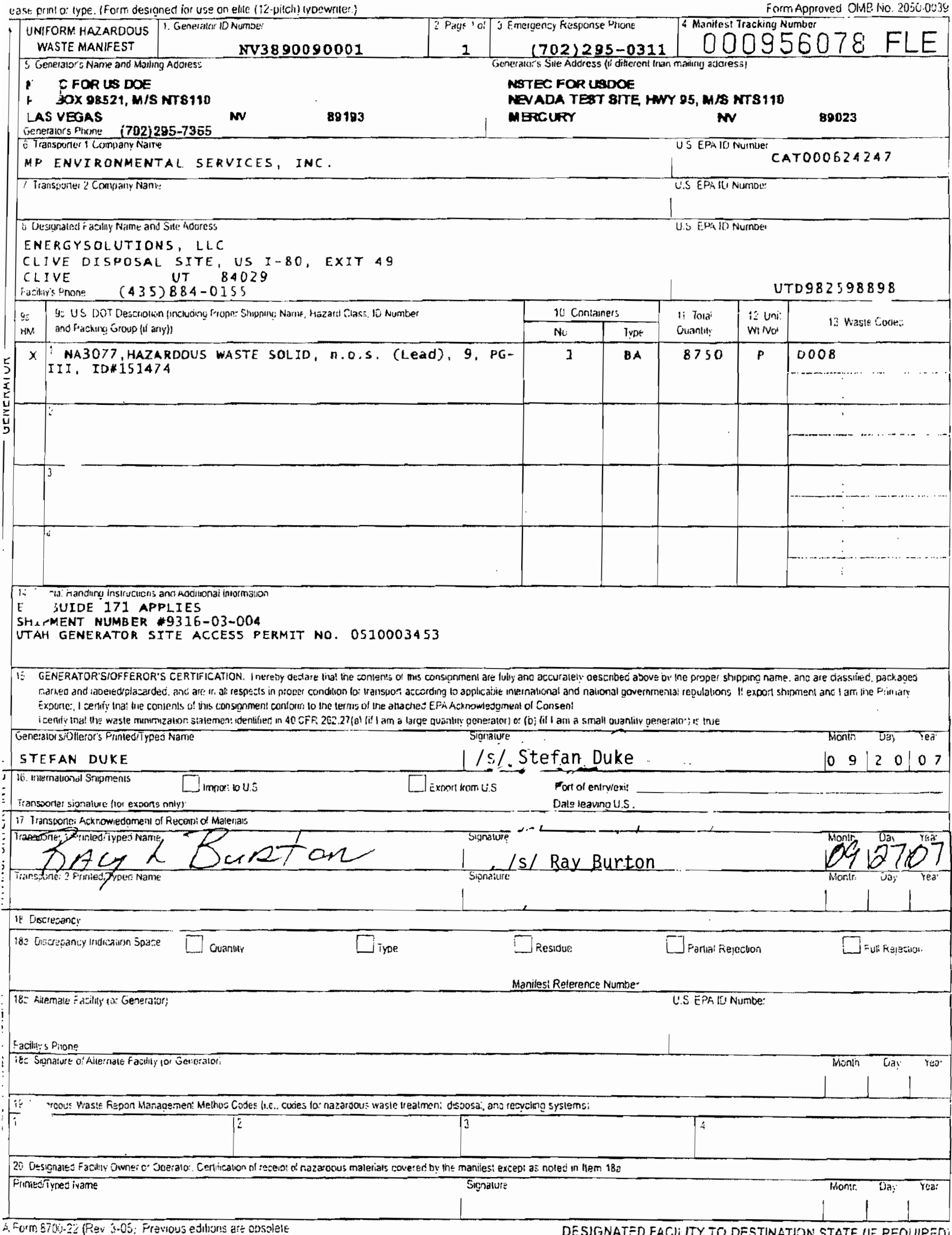


(AU 127 Closure Repori

Section: Appendix D

Revision: 0

Diltc: Fcbruary 2008

\section{APPENDIX D}

\section{USE RESTRICTION DOCUMENTATION}


CAU 127 Closure Report

Section: Appendix D

Revision: 0

Date: I cbruary 2008

THIS PAGE INTENTIONALLY LEFT BLANK 


\section{CAU Use Restriction Information}

CAU Number/Description: CAU 127: Areas 25 and 26 Storage Tanks

Applicable CAS Numbers/Descriptions: CAS 25-01-07. Aboveground Storage Tank

Contact (organization/project): NNSANSO Federal Sub-Project Director

Surveyed Area (UTM, Zone 11, NAD 27, meters):

\begin{tabular}{|c|c|c|}
\hline LR POINS & NORTHING & EASTINC \\
\hline Point 1 & 4.073 .538 .691 & 562.171 .283 \\
\hline Point 2 & 4.073 .544 .356 & 562.172 .559 \\
\hline Point 3 & $4,073.543 .335$ & 562.176 .244 \\
\hline Point 4 & $4,073.537 .772$ & 562.174 .906 \\
\hline
\end{tabular}

Survey Date: 10/29/2007 Survey Method (GPS, etc): GPS

Site Monitoring Requirements: Visual Inspections

Required Frequency (quarterly, annually?): Annual

If Monitoring Has Started, Indicate last Completion Date: N/A

\section{Use Restrictions}

The future use of any land related to this Corrective Action Unit (CAU), as described by the above surveyed location, is restricted from any DOE or Air Force activity that may alter or modify the containment control as approved by the state and identified in the CAU Closure Report or other CAU documentation unless appropriate concurrence is obtained in advance.

Comments: See the Closure Report for additional information on the condition of the site(s) and any monitoring and/or inspection requirements.

Submitted By: $\_\leq /$Kevin Cabble Date:

cc with copy of survey map (paper and digital (dgn) formats):

CAU Files (2 copies) 


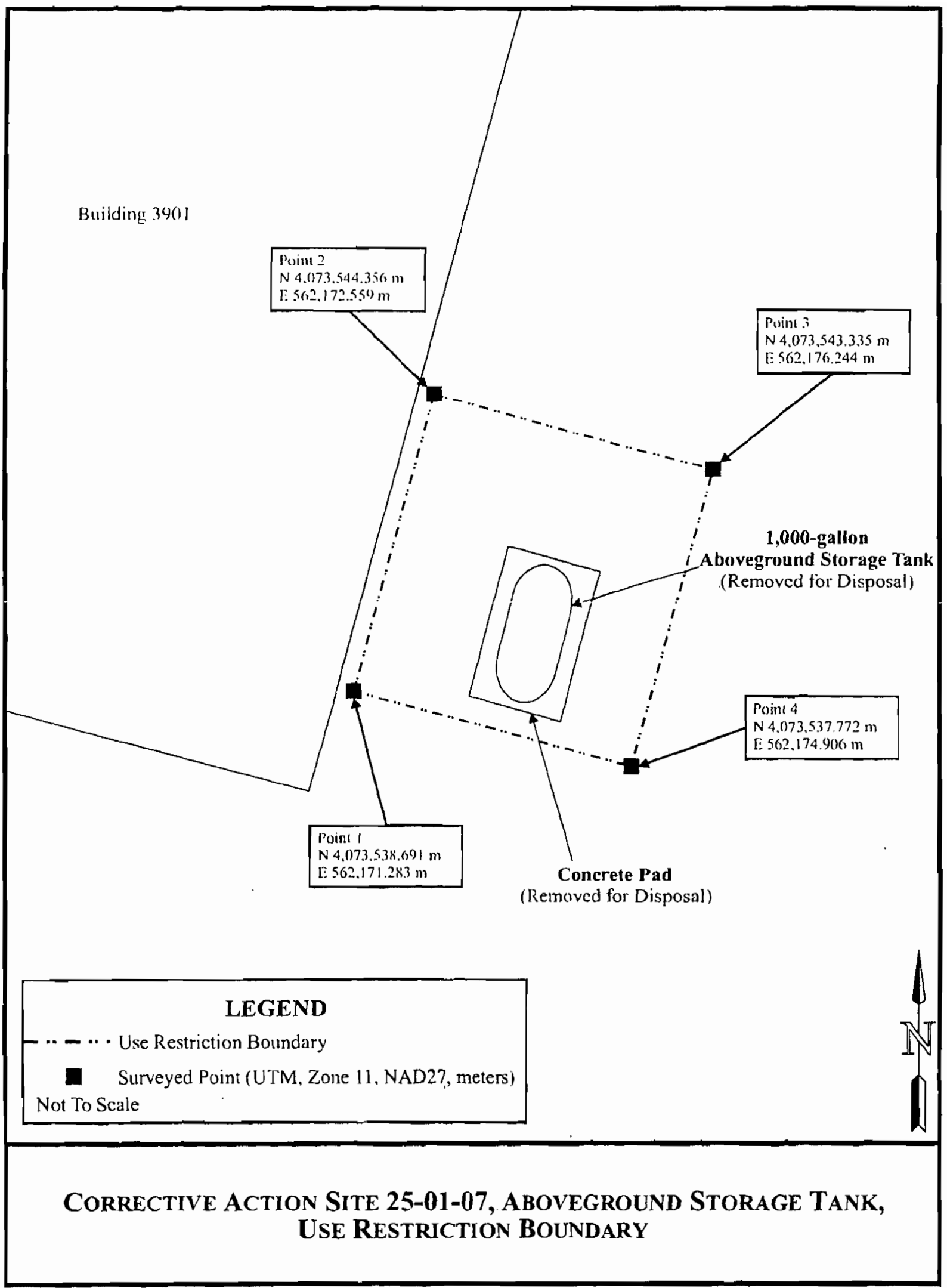




\section{CAU Use Restriction Information}

CAU Number/Description: CAL: 127: Areas 25 and 26 Storage Tanks

Applicable CAS Numbers/Descriptions: CAS 25-02-02, Unclerground Storage Tank

Contact (organization/project): NNSA/NSO Federal Sub-Project Director

Surveyed Area (UTM, Zone 11, NAD 27, meters):

\begin{tabular}{|c|c|c|}
\hline UR POINTS & NORTHING & EASTRG \\
\hline Point 1 & $4,076.144 .044$ & 564.632 .679 \\
\hline Point 2 & $4,076.156 .309$ & 564.618 .766 \\
\hline Point 3 & 4.076 .139 .836 & 564.601 .028 \\
\hline Point 4 & $4,076,127.547$ & 564.610 .633 \\
\hline Point 5 & $4,076.128 .673$ & 564.618 .563 \\
\hline
\end{tabular}

Survey Date: 10/29/2007 Survey Method (GPS, etc): GPS

Site Monitoring Requirements: Visual Inspections

Required Frequency (quarterly, annually?): Annual

If Monitoring Has Started, Indicate last Completion Date: $\underline{\mathrm{N} / \mathrm{A}}$

\section{Use Restrictions}

The future use of any land related to this Corrective Action Unit (CAU), as described by the above surveyed location, is restricted from any DOE or Air Force activity that may alter or modify the containment control as approved by the state and identified in the CAU Closure Report or other CAU documentation unless appropriate concurrence is obtained in advance.

Comments: See the Closure Report for additional information on the condition of the site(s) and any monitoring and/or inspection requirements.

Submitted By: _ / $/$ / Kevin Cabble

Date: $2-3-6$

cc with copy of survey map (paper and digital (dgn) formats):

CAU Files ( 2 copies) 


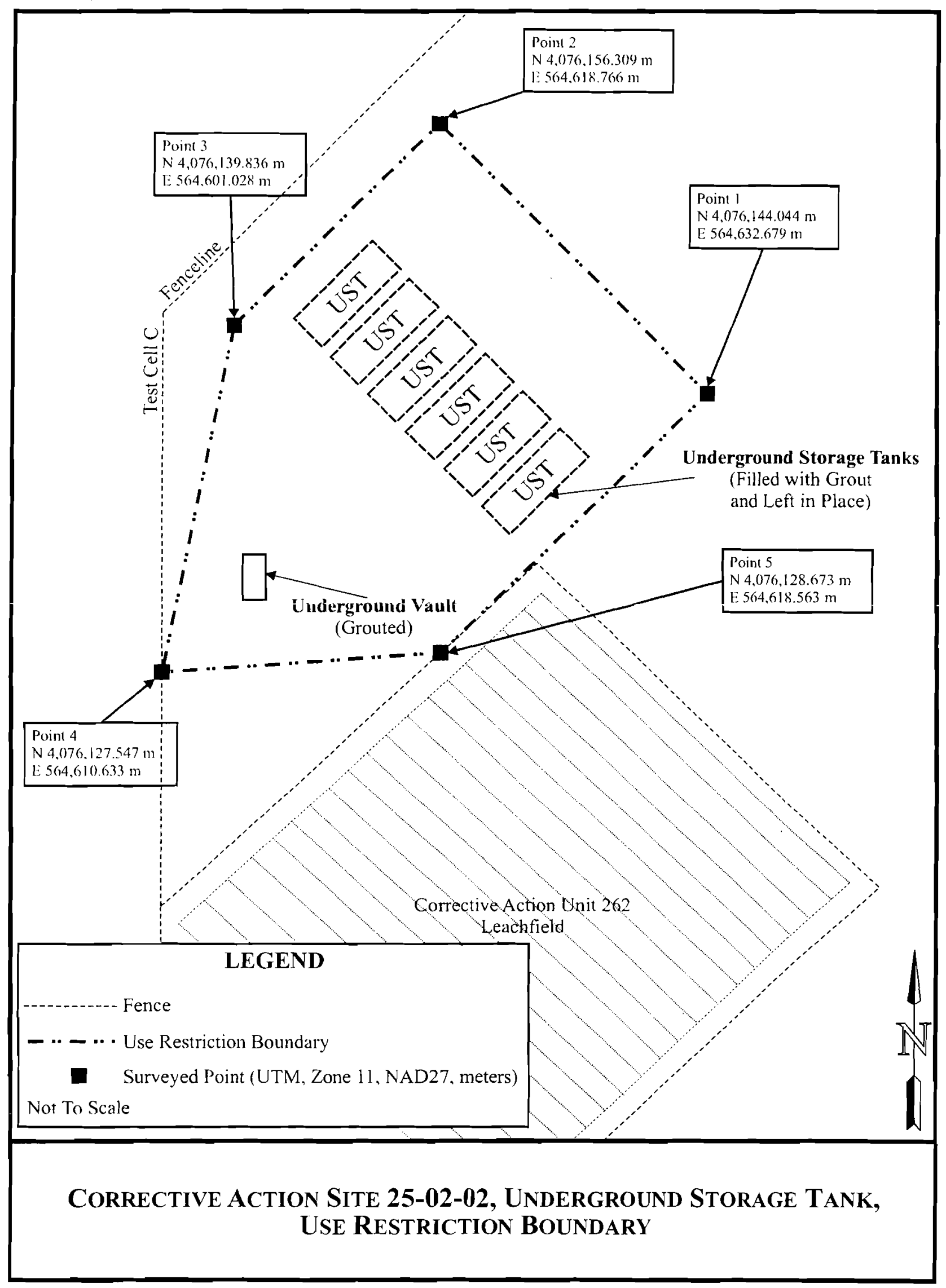


CAU 127 Closure Report

Section: Appendix E

Revision: 0

Date: February 2008

\section{APPENDIX E}

\section{SITE CLOSURE PHOTOGRAPHS}


CAU 127 Closure Report

Section: Appendix E

Revision: 0

Date: February 2008

THIS PAGE INTENTIONALLY LEFT BLANK 


\section{PHOTOGRAPH LOG}

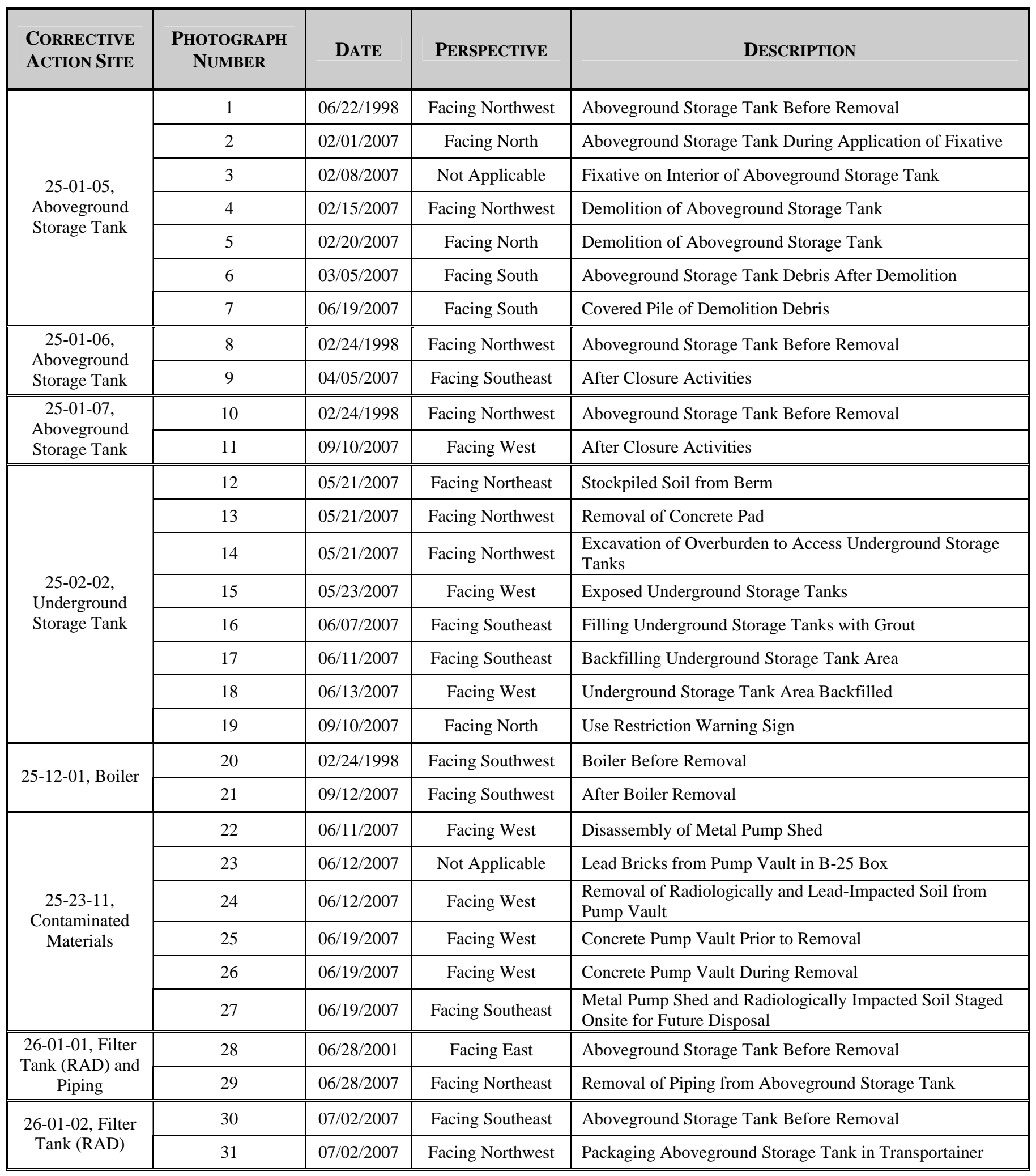


CAU 127 Closure Report

Section: Appendix E

Revision: 0

Date: February 2008

\begin{tabular}{|c|c|c|c|l||}
\hline CoRRECTIVE & PHOTOGRAPH & DATE & PERSPECTIVE & \\
ACTION SiTE & NuMBER & DESCRIPTION \\
\hline \hline $\begin{array}{c}\text { 26-02-01, } \\
\text { Underground } \\
\text { Storage Tank }\end{array}$ & 32 & $02 / 28 / 2001$ & Facing Northwest & Underground Storage Tank Before Closure Activities \\
\cline { 2 - 5 } & 33 & $11 / 28 / 2007$ & Facing North & Underground Storage Tank After Closure Activities \\
\hline \hline $\begin{array}{c}\text { 26-23-01, } \\
\text { Contaminated } \\
\text { Liquids Spreader }\end{array}$ & 35 & $03 / 12 / 1998$ & Facing Northeast & Spreader Before Removal \\
\hline \hline \multirow{2}{*}{$\begin{array}{c}\text { 26-99-01, } \\
\text { Radioactively } \\
\text { Contaminated } \\
\text { Filters }\end{array}$} & 36 & $06 / 28 / 2001$ & Facing East & Wooden Shed with Filter Tanks Before Removal \\
\cline { 2 - 6 } & 38 & $07 / 03 / 2007$ & Facing East & Filter Tanks Before Removal \\
\cline { 2 - 6 } & 39 & $07 / 10 / 2007$ & Facing Southwest & Demolition of Wooden Shed \\
\hline \hline
\end{tabular}




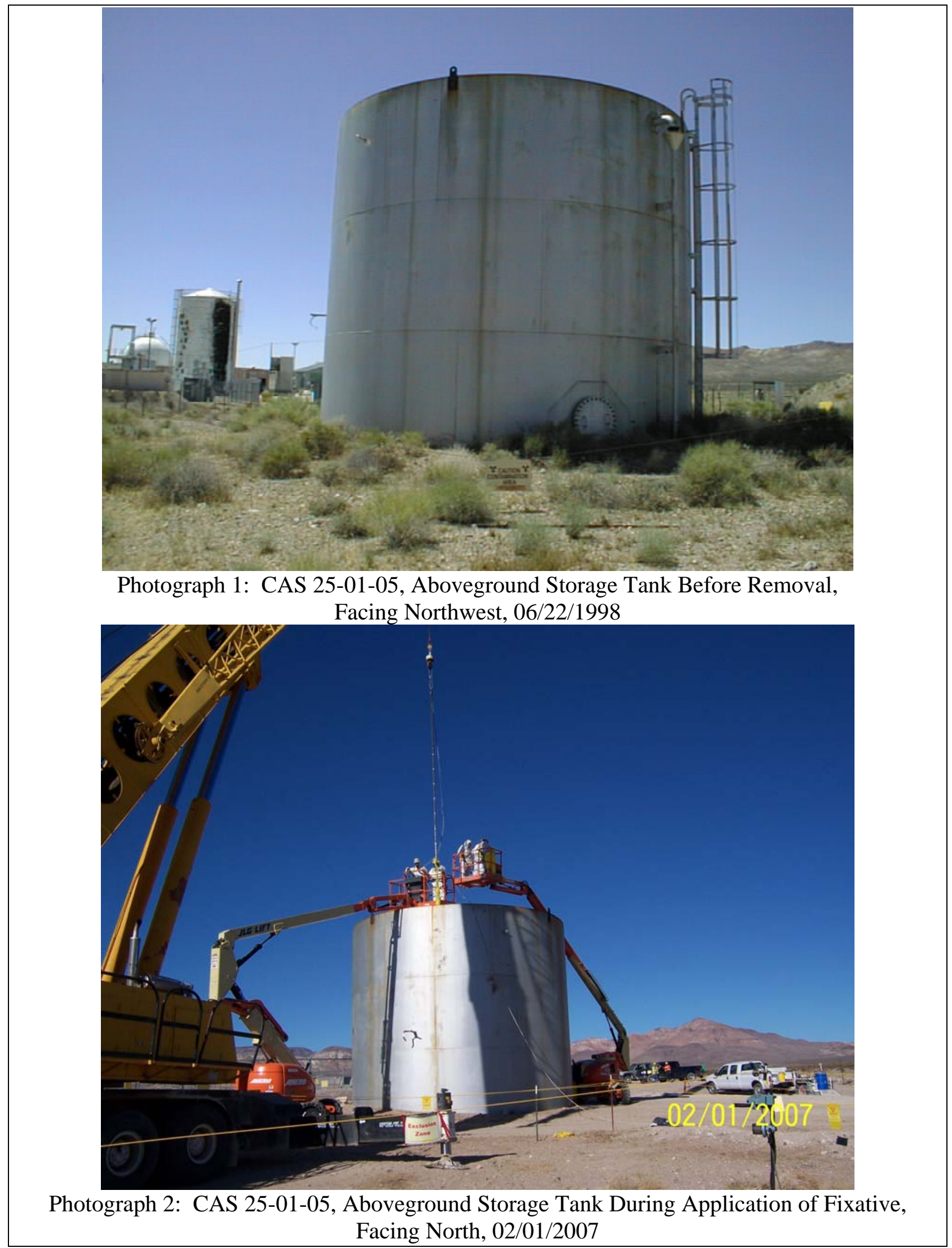




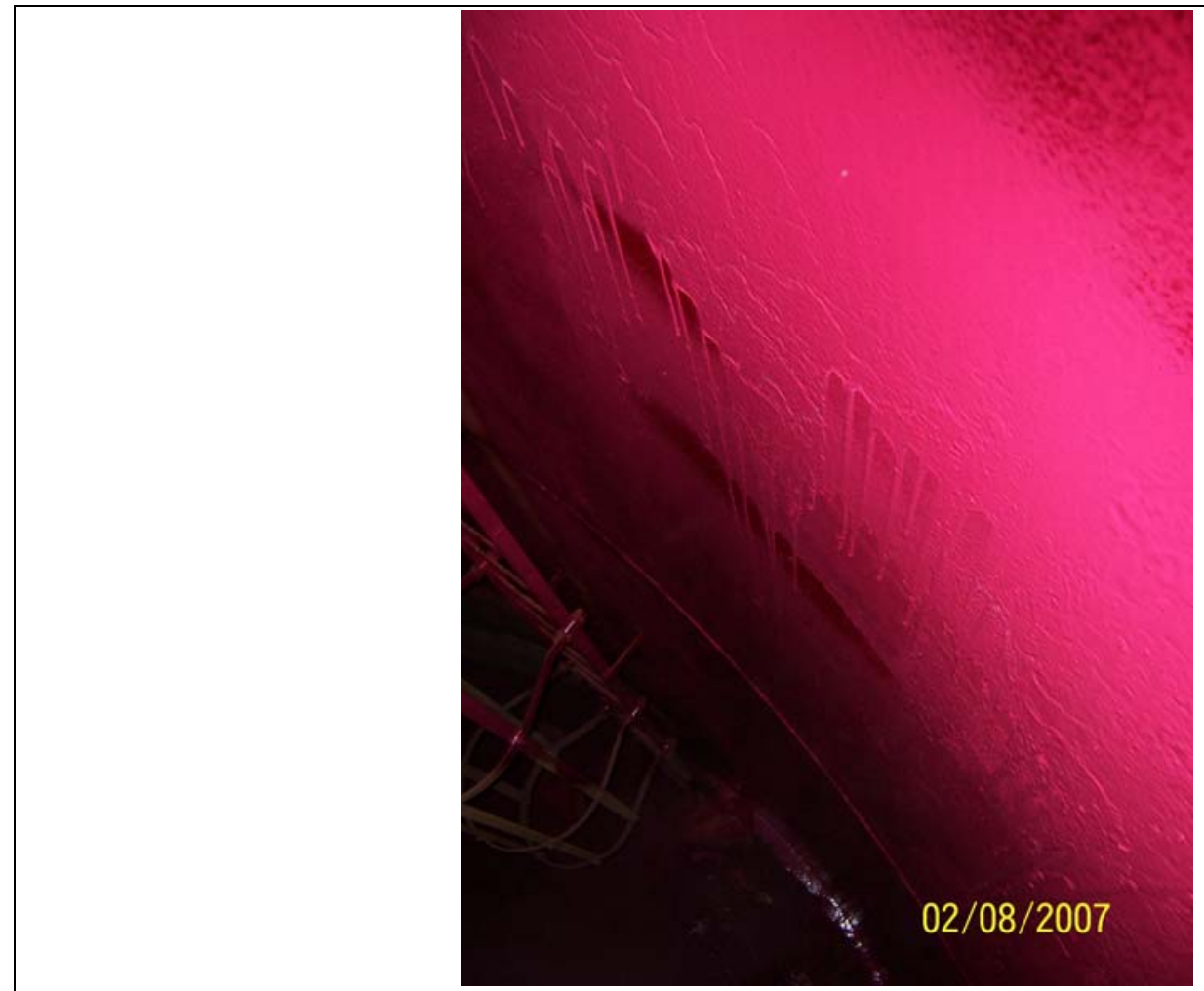

Photograph 3: CAS 25-01-05, Fixative on Interior of Aboveground Storage Tank, 02/08/2007

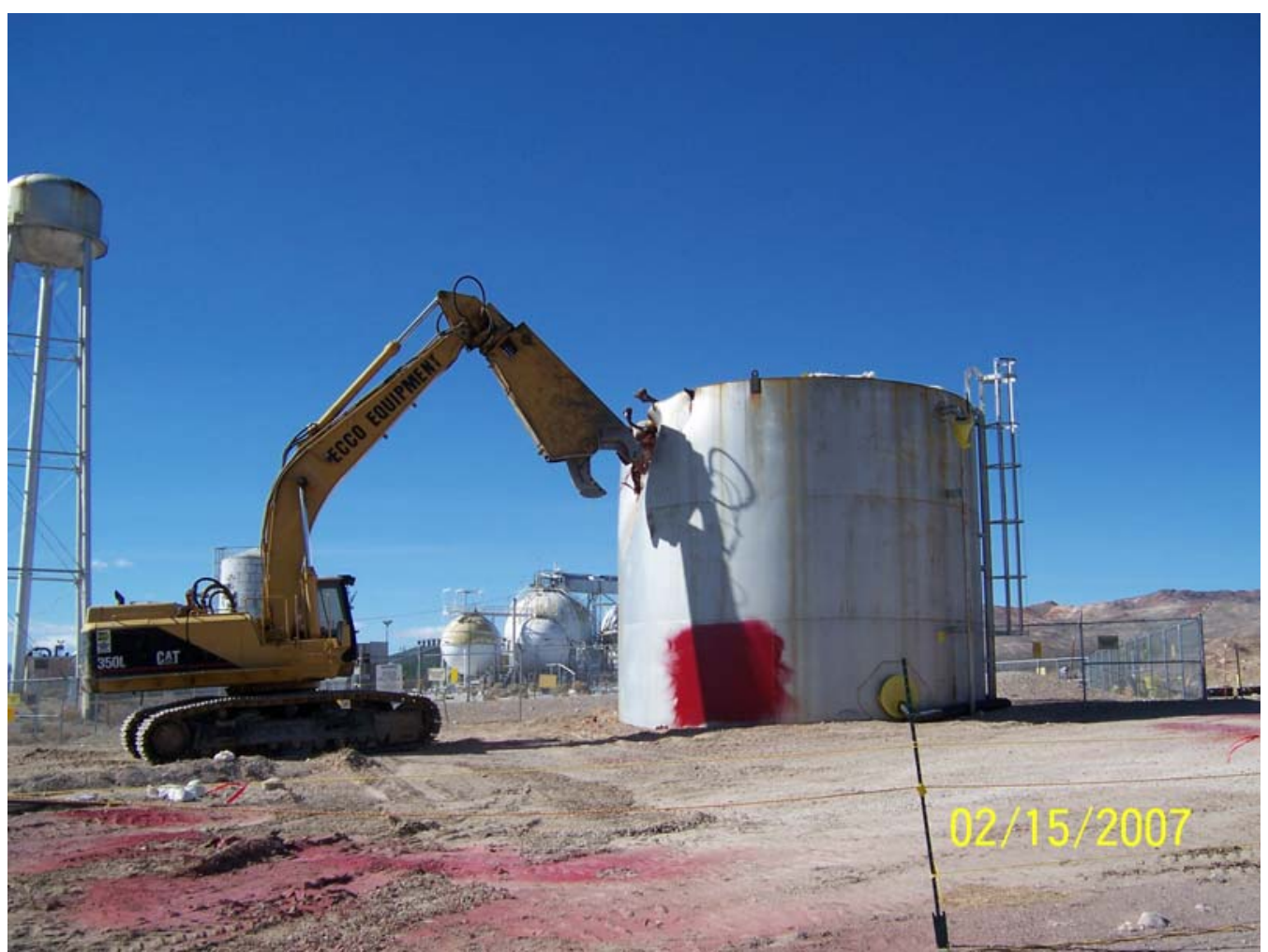

Photograph 4: CAS 25-01-05, Demolition of Aboveground Storage Tank, Facing Northwest, 02/15/2007 


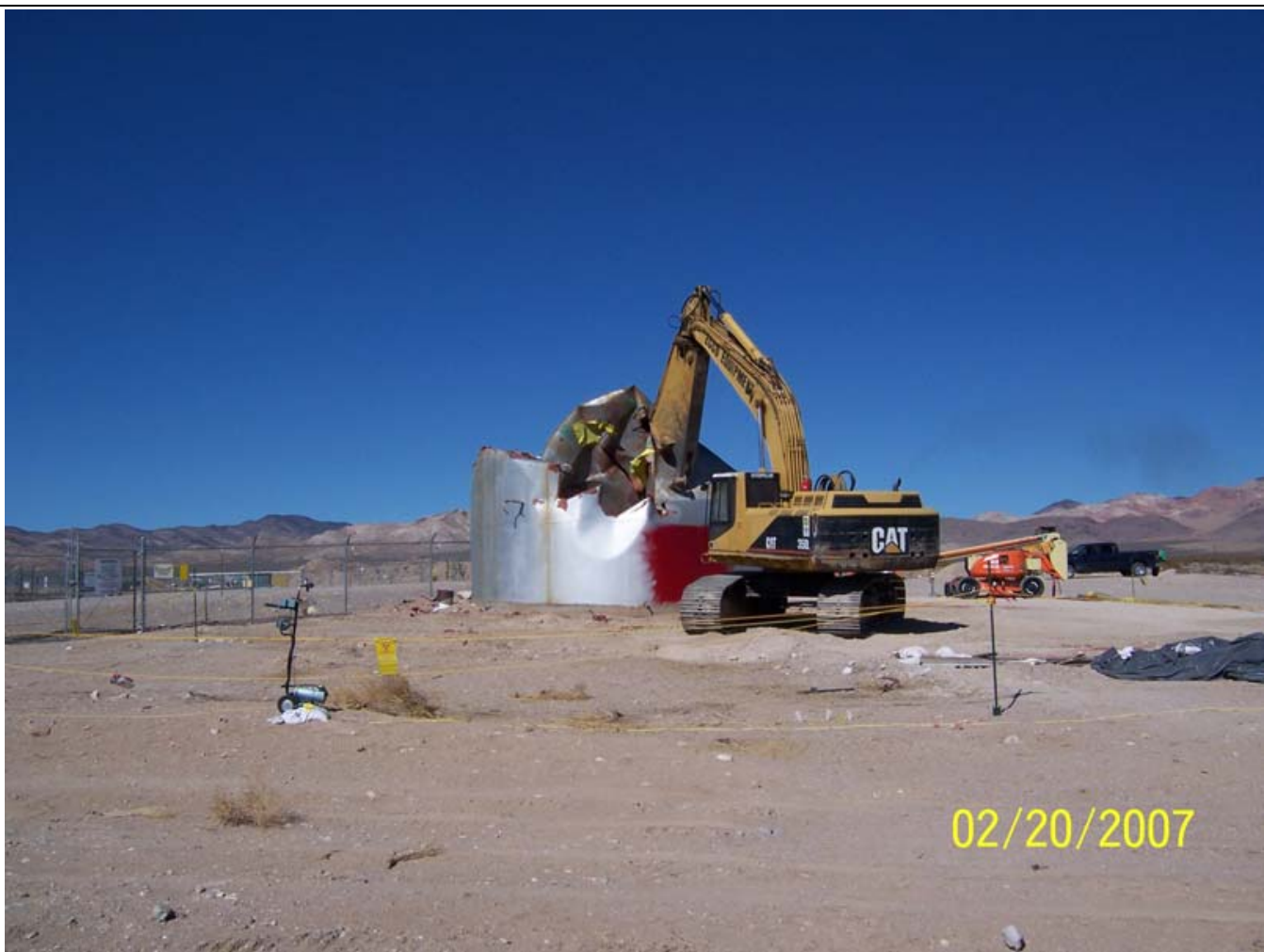

Photograph 5: CAS 25-01-05, Demolition of Aboveground Storage Tank, Facing North, 02/20/2007

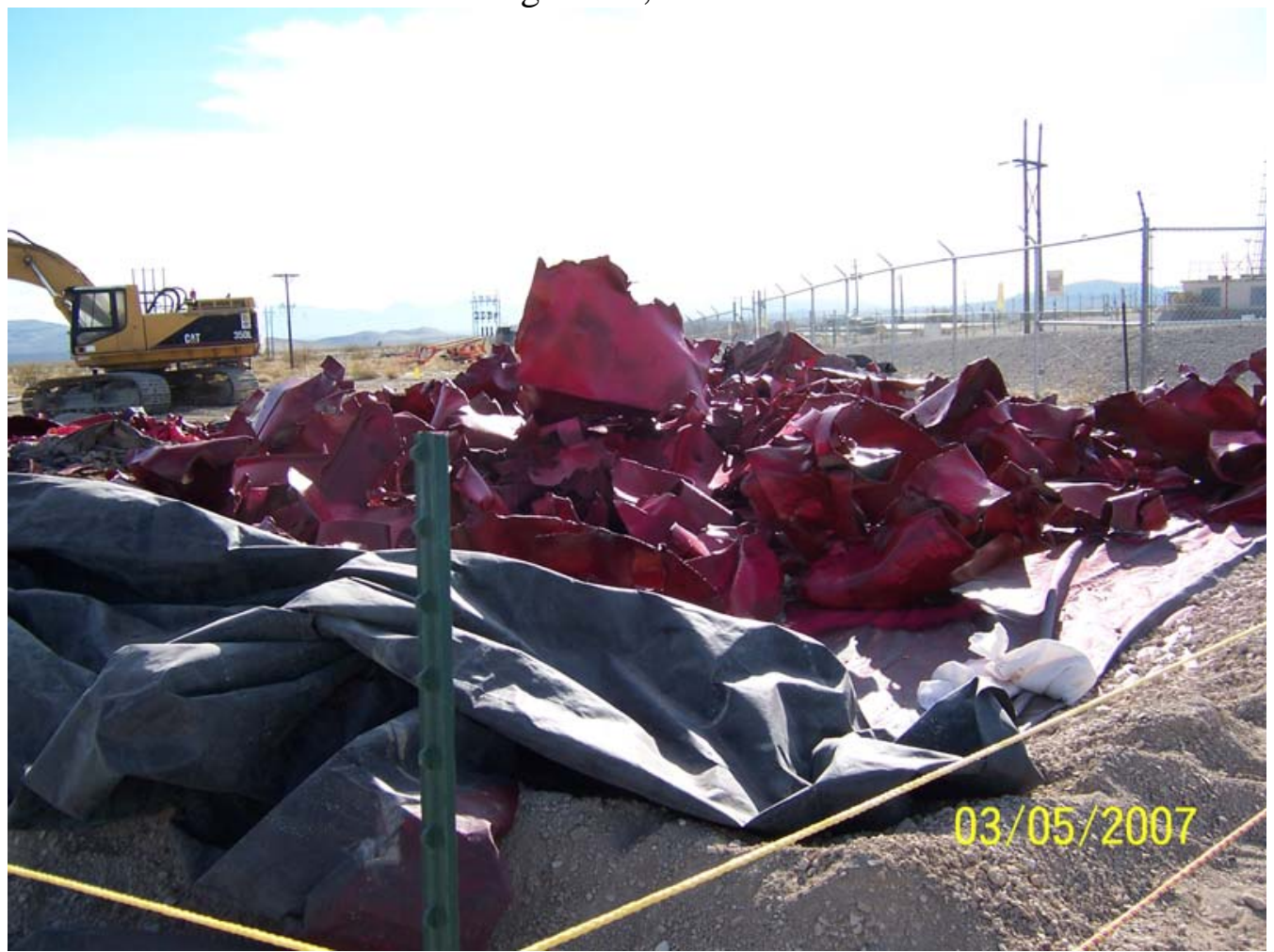

Photograph 6: CAS 25-01-05, Aboveground Storage Tank Debris After Demolition, Facing South, 03/05/2007 


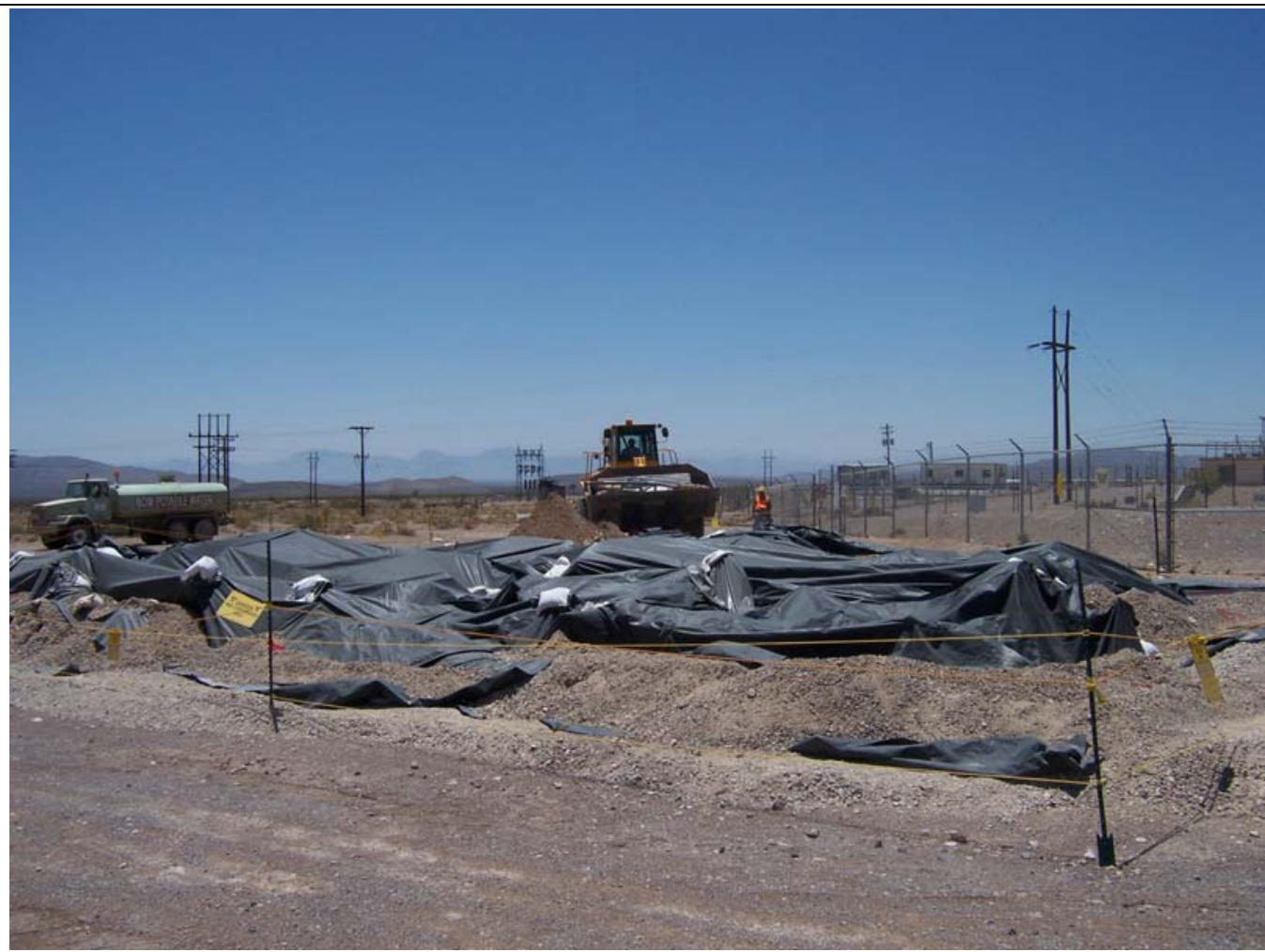

Photograph 7: CAS 25-01-05, Covered Pile of Demolition Debris, Facing South, 06/19/2007

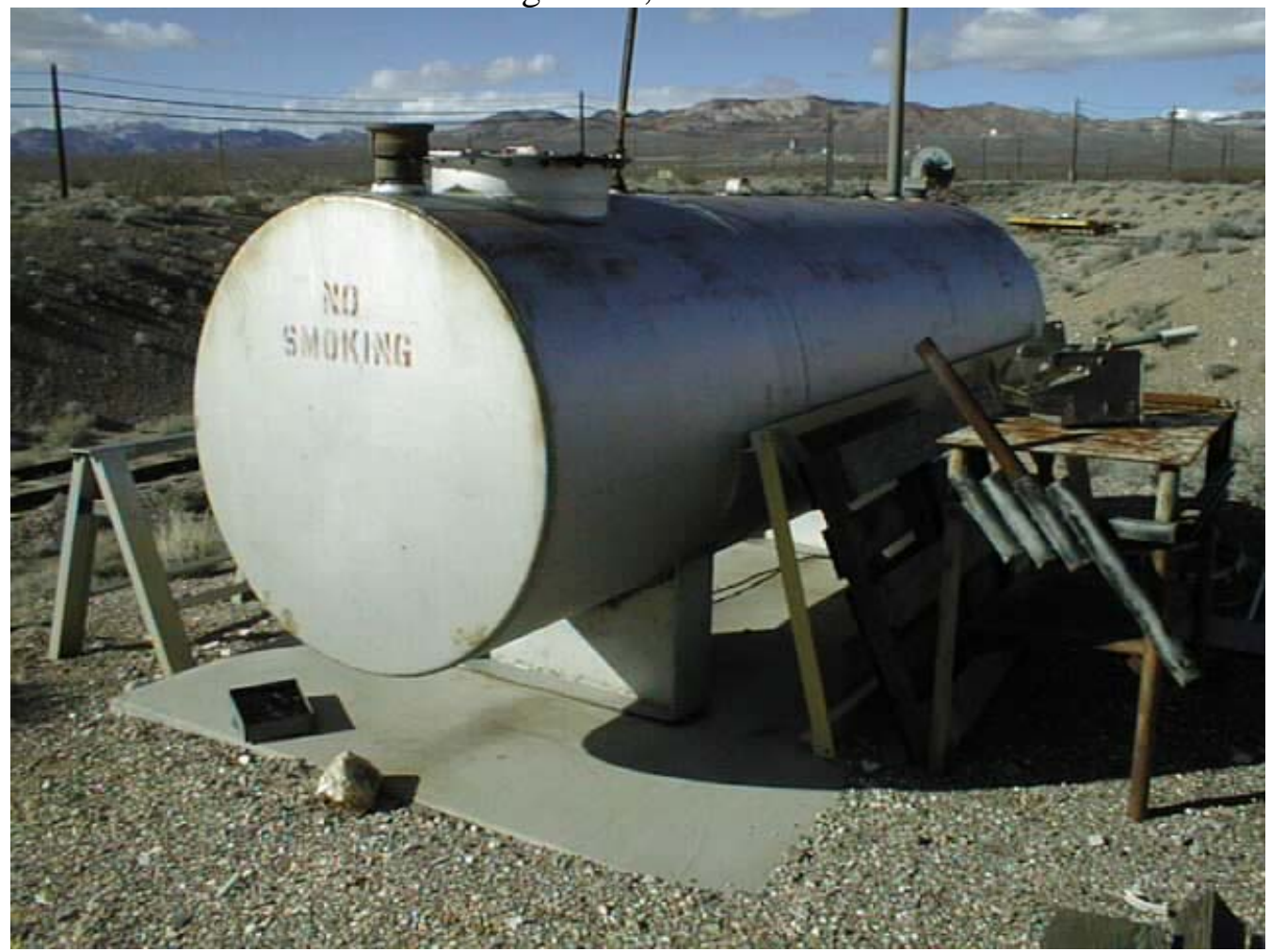

Photograph 8: CAS 25-01-06, Aboveground Storage Tank Before Removal, Facing Northwest, 02/24/1998 


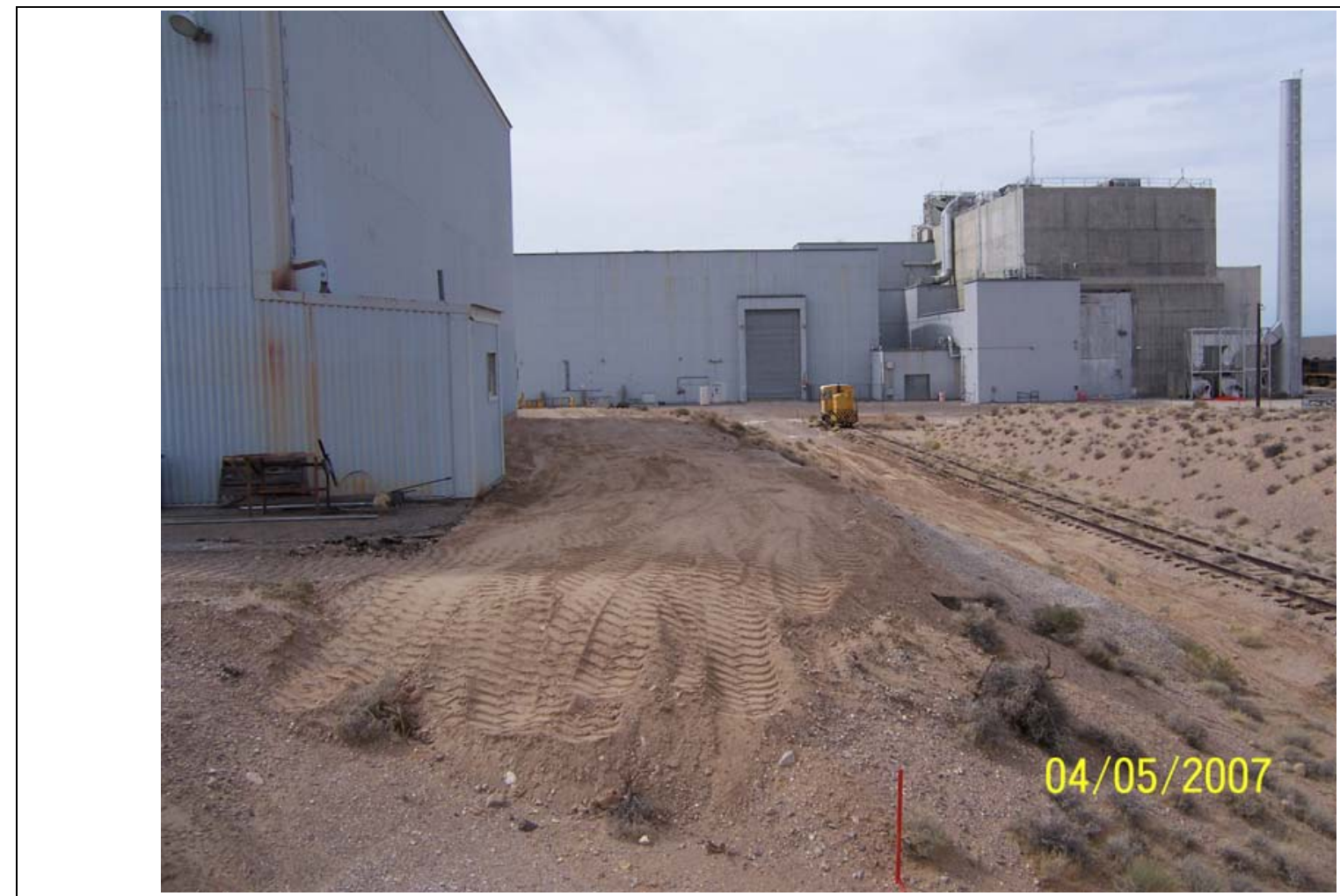

Photograph 9: CAS 25-01-06, After Closure Activities, Facing Southeast, 04/05/2007

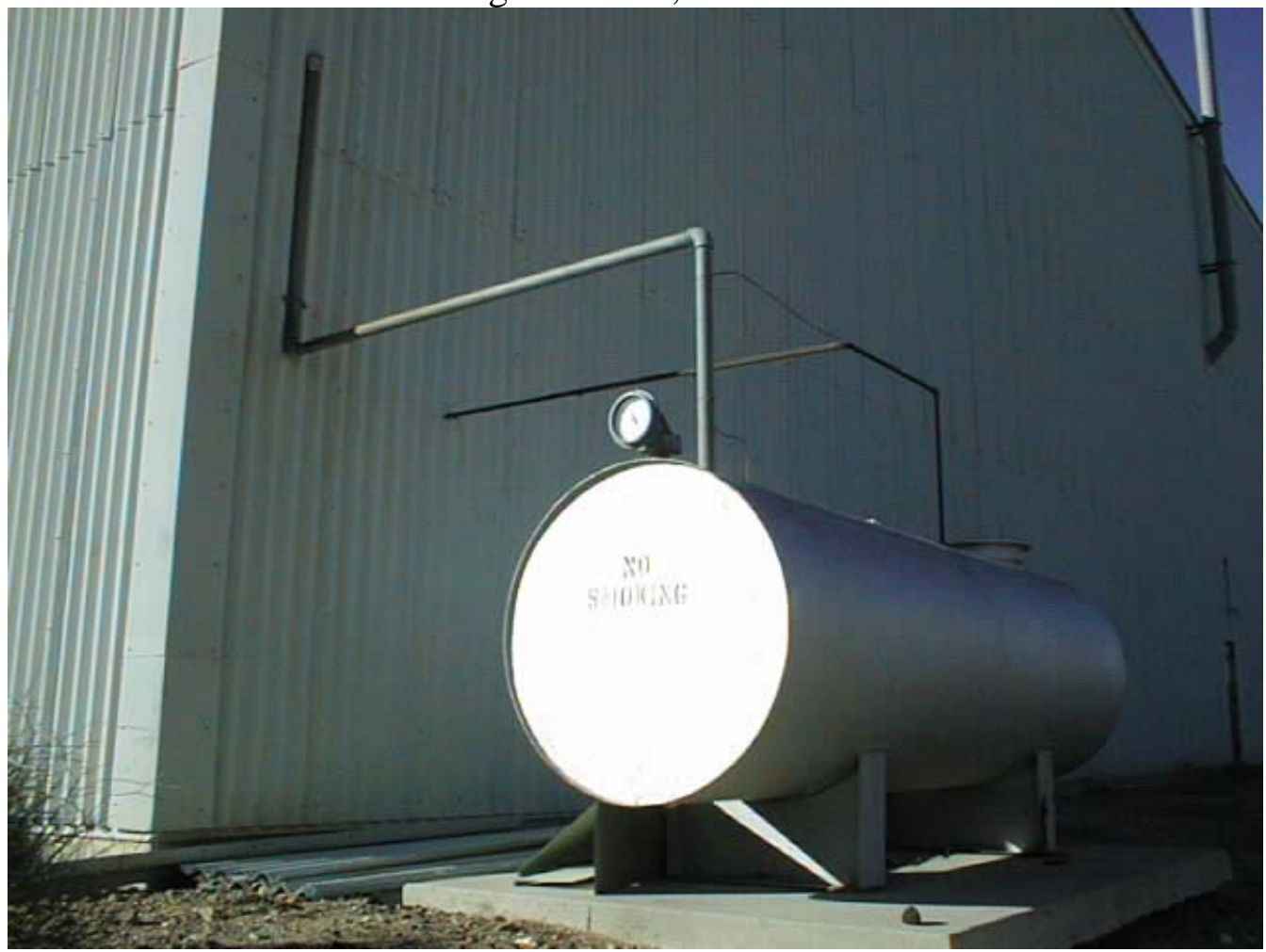

Photograph 10: CAS 25-01-07, Aboveground Storage Tank Before Removal, Facing Northwest, 02/24/1998 


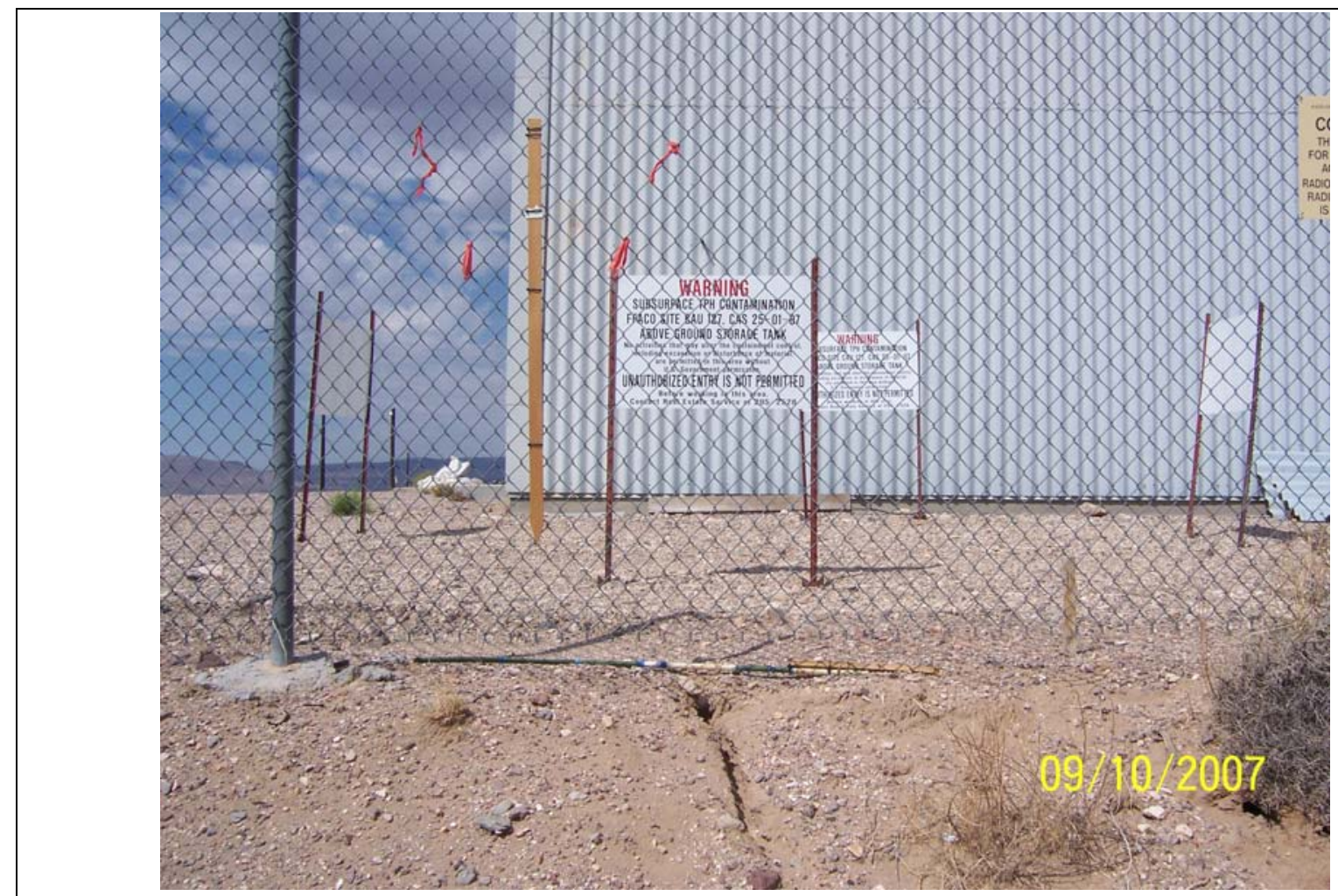

Photograph 11: CAS 25-01-07, After Closure Activities, Facing West, 09/10/2007

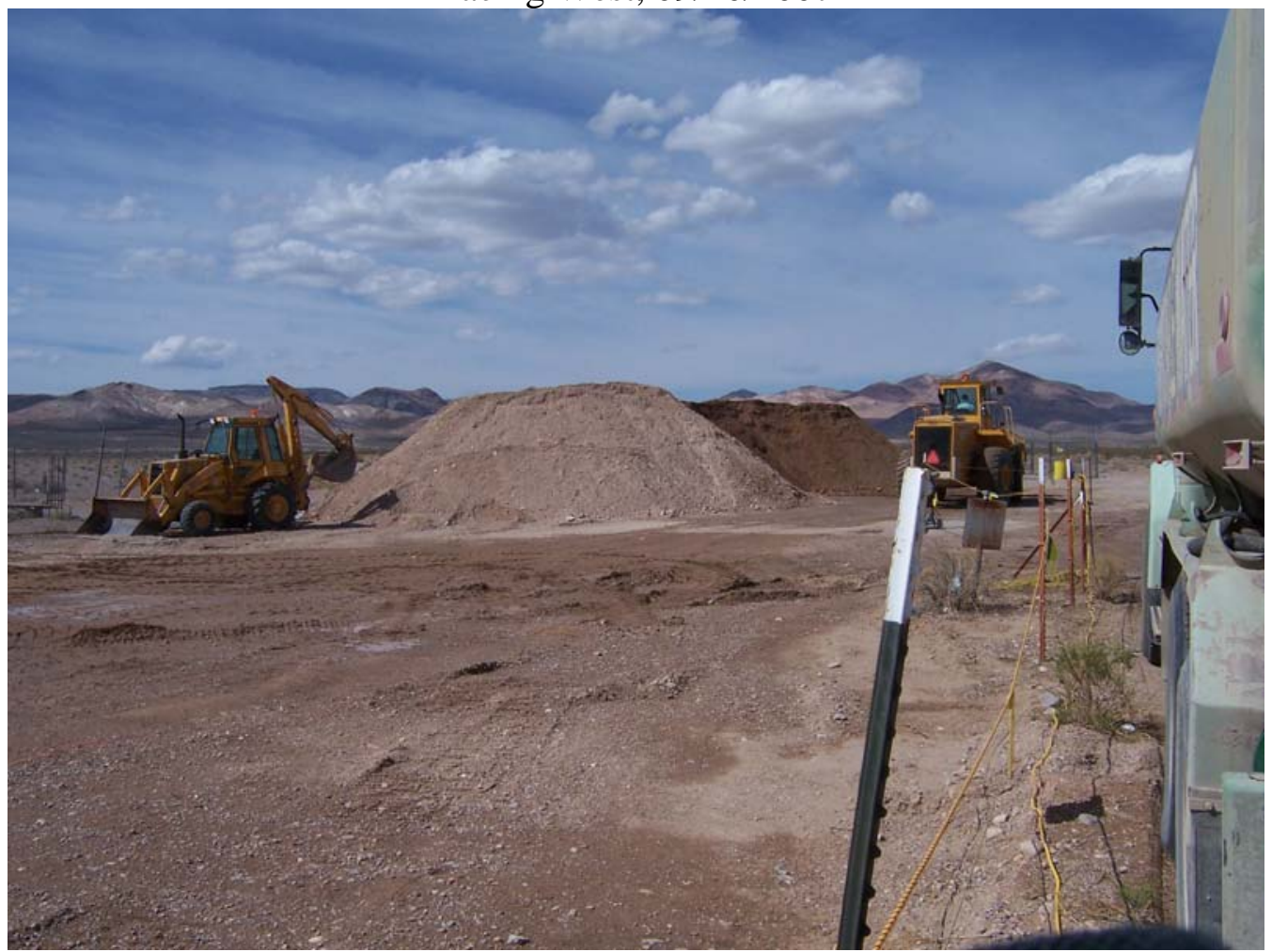

Photograph 12: CAS 25-02-02, Stockpiled Soil from Berm,

Facing Northeast, 05/21/2007 


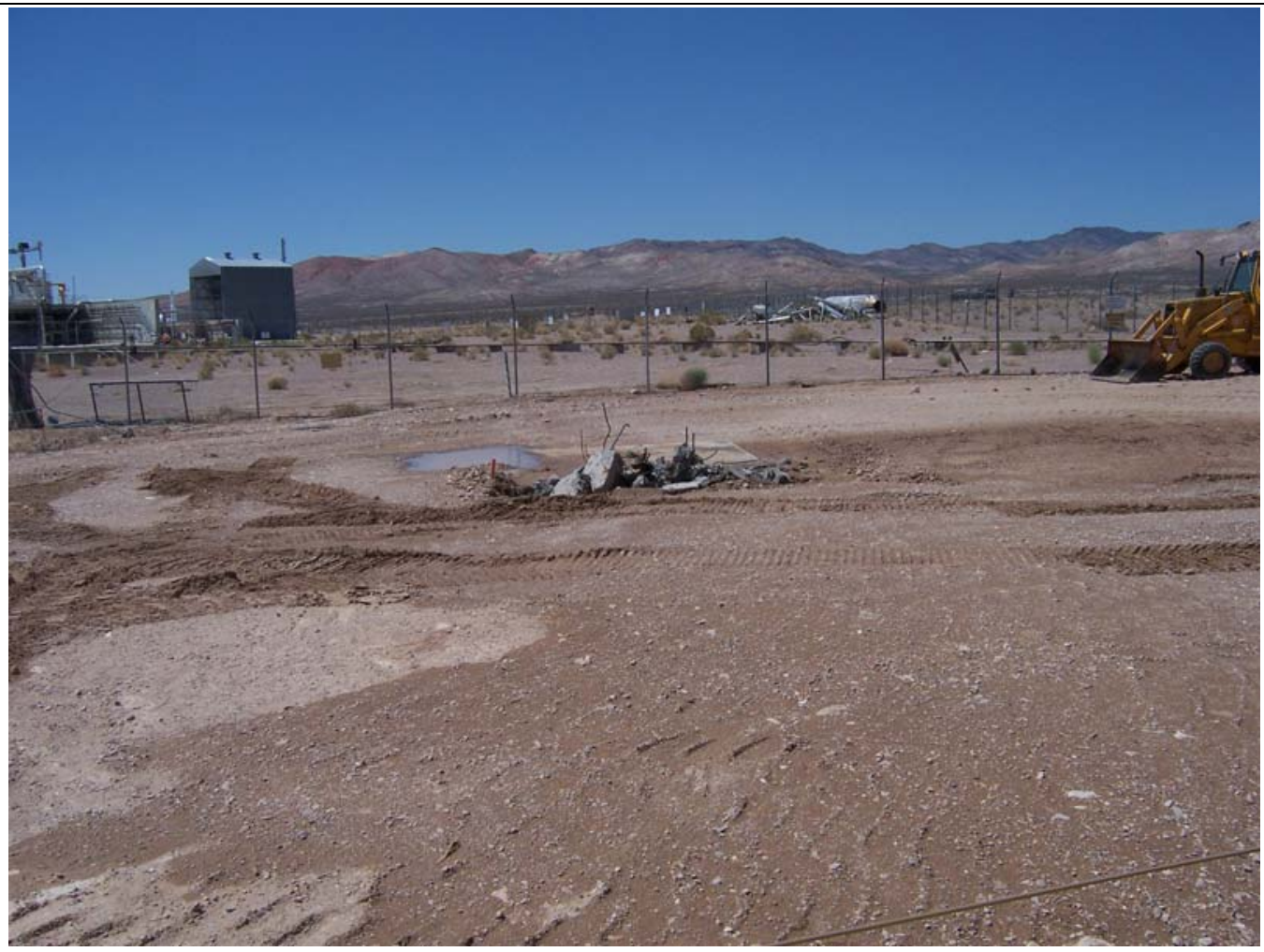

Photograph 13: CAS 25-02-02, Removal of Concrete Pad,

Facing Northwest, 05/21/2007

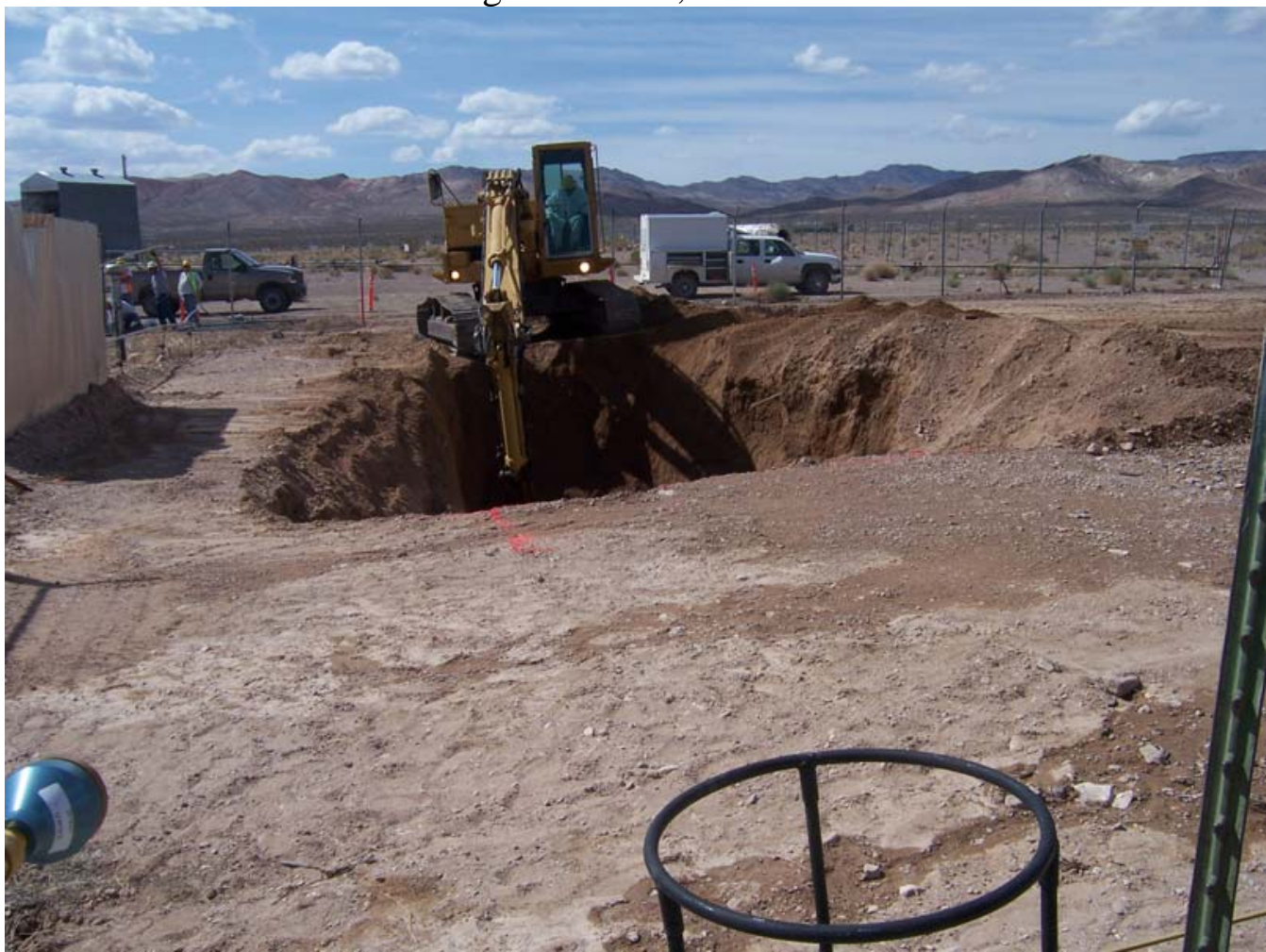

Photograph 14: CAS 25-02-02, Excavation of Overburden to Access Underground Storage Tanks, Facing Northwest, 05/21/2007 


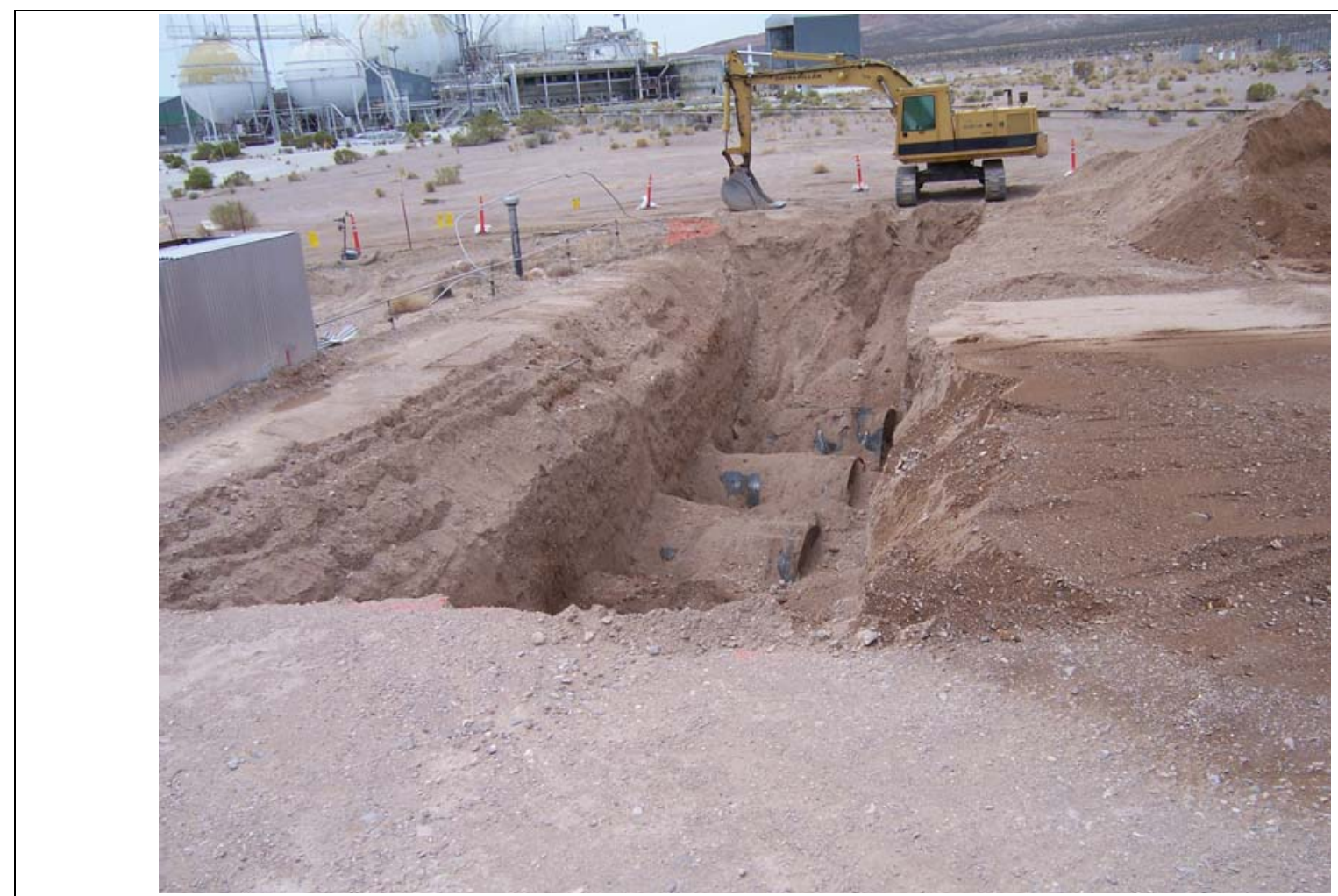

Photograph 15: CAS 25-02-02, Exposed Underground Storage Tanks, Facing West, 05/23/2007

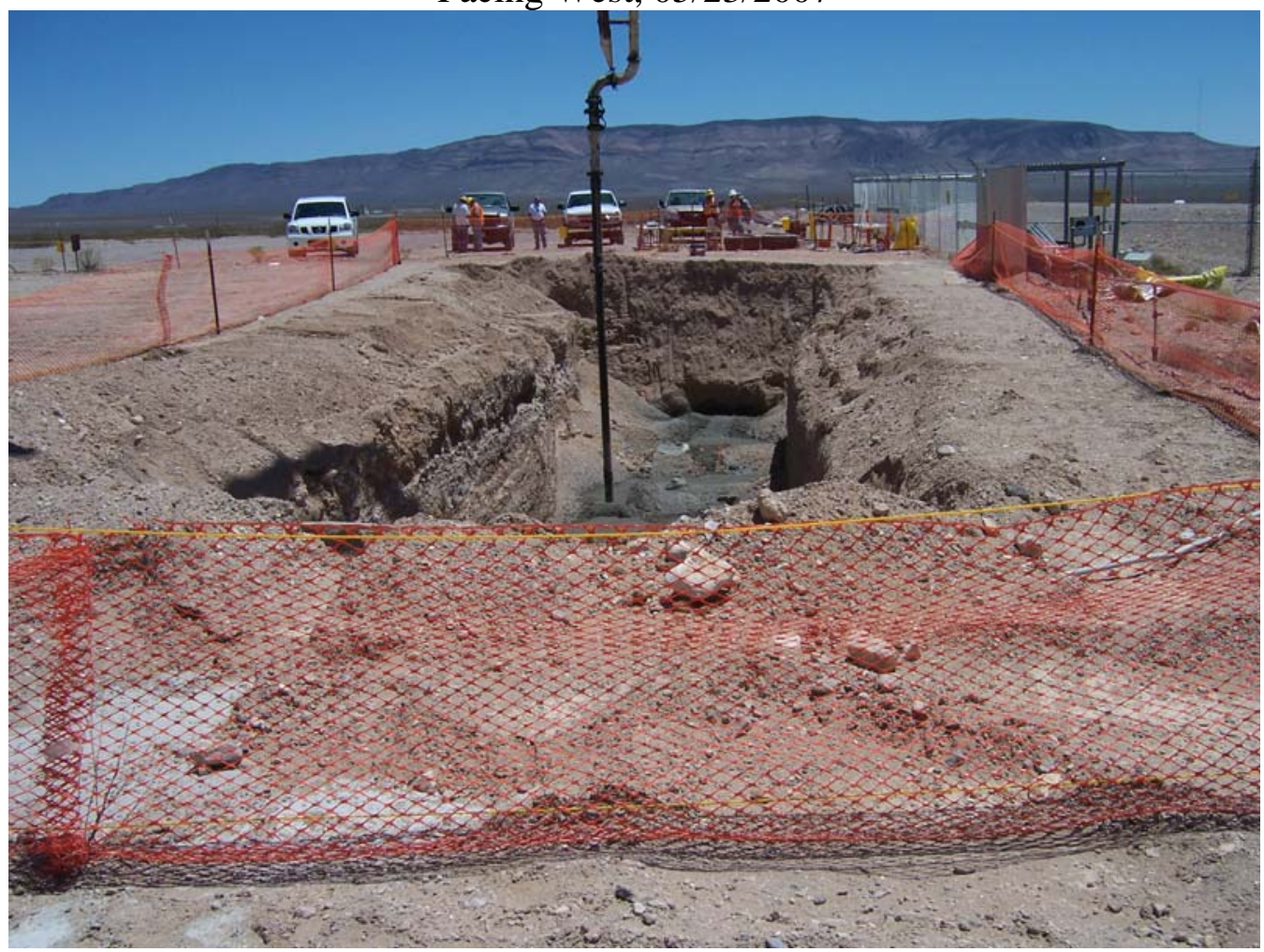

Photograph 16: CAS 25-02-02, Filling Underground Storage Tanks with Grout, Facing Southeast, 06/07/2007 


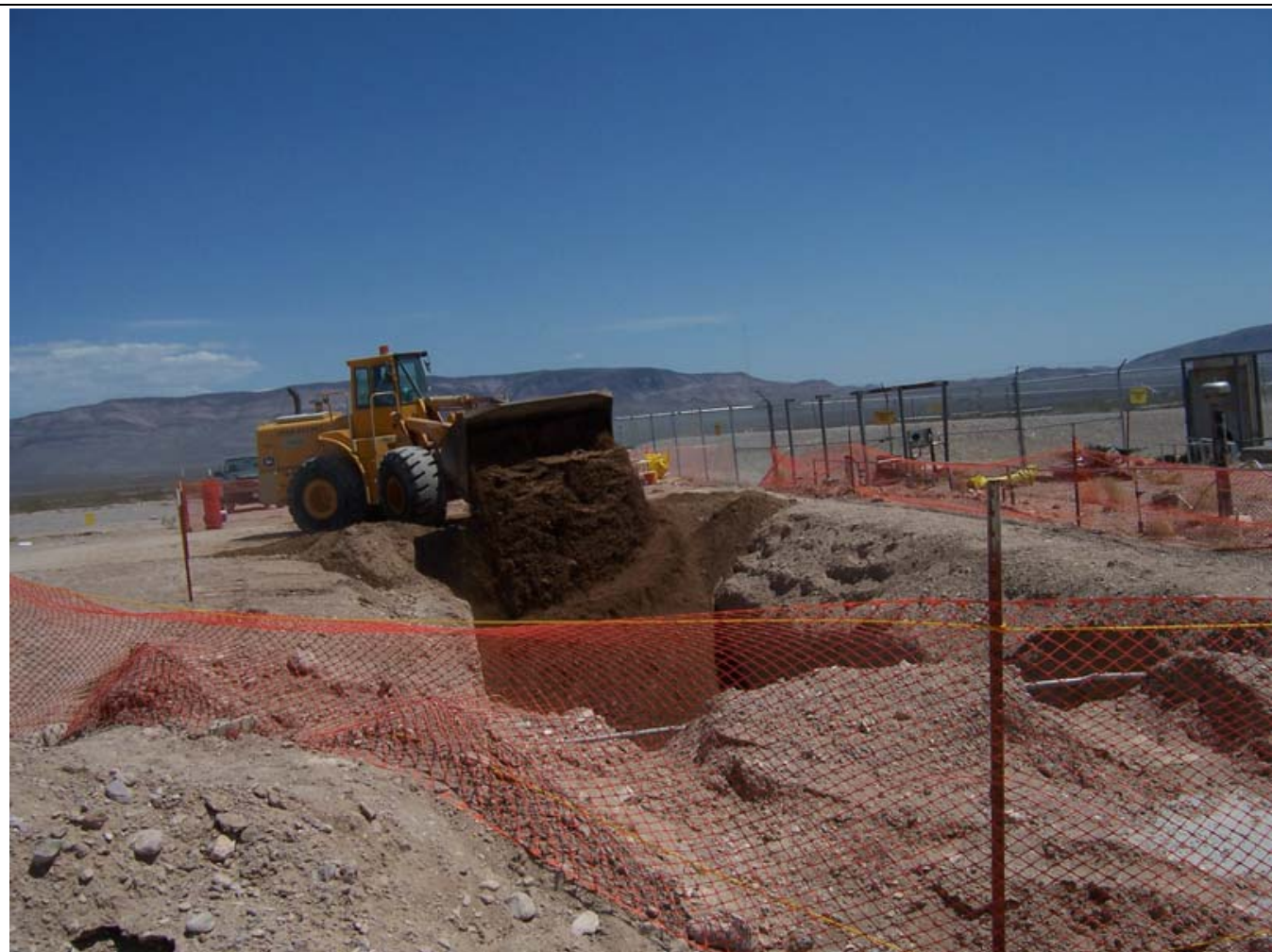

Photograph 17: CAS 25-02-02, Backfilling Underground Storage Tank Area, Facing Southeast, 06/11/2007

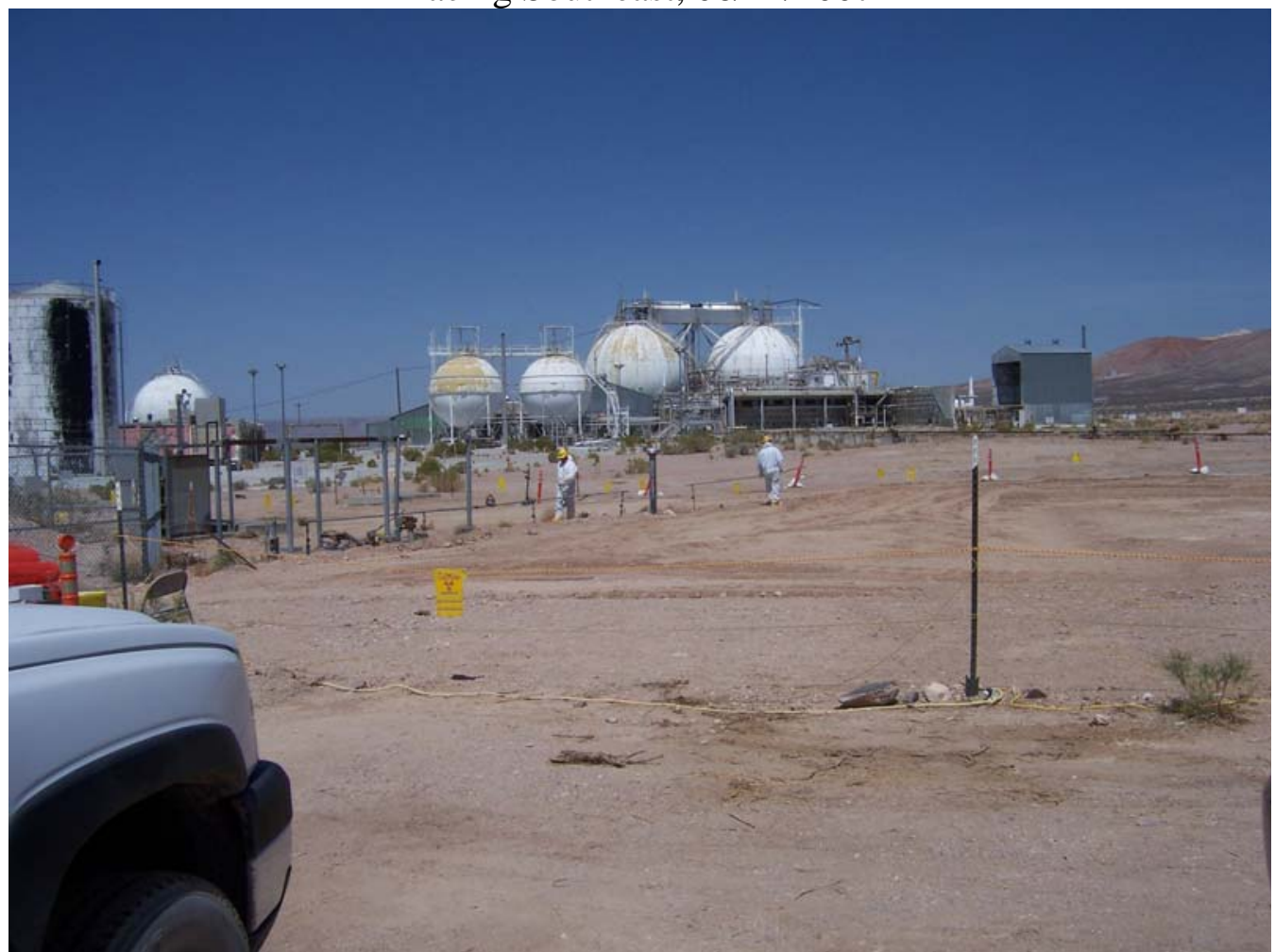

Photograph 18: CAS 25-02-02, Underground Storage Tank Area Backfilled, Facing West, 06/13/2007 


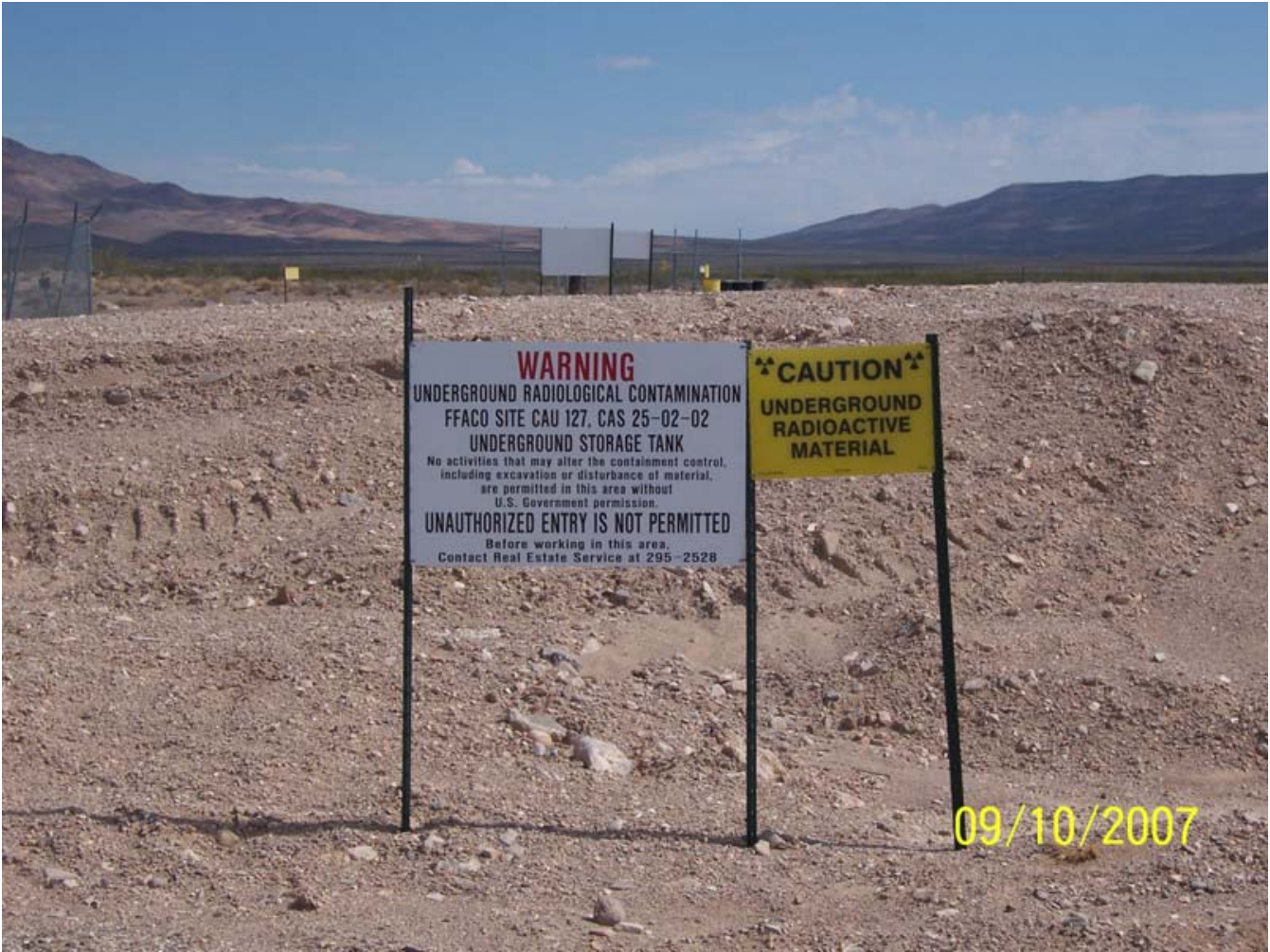

Photograph 19: CAS 25-02-02, Use Restriction Warning Sign, Facing North, 09/10/2007

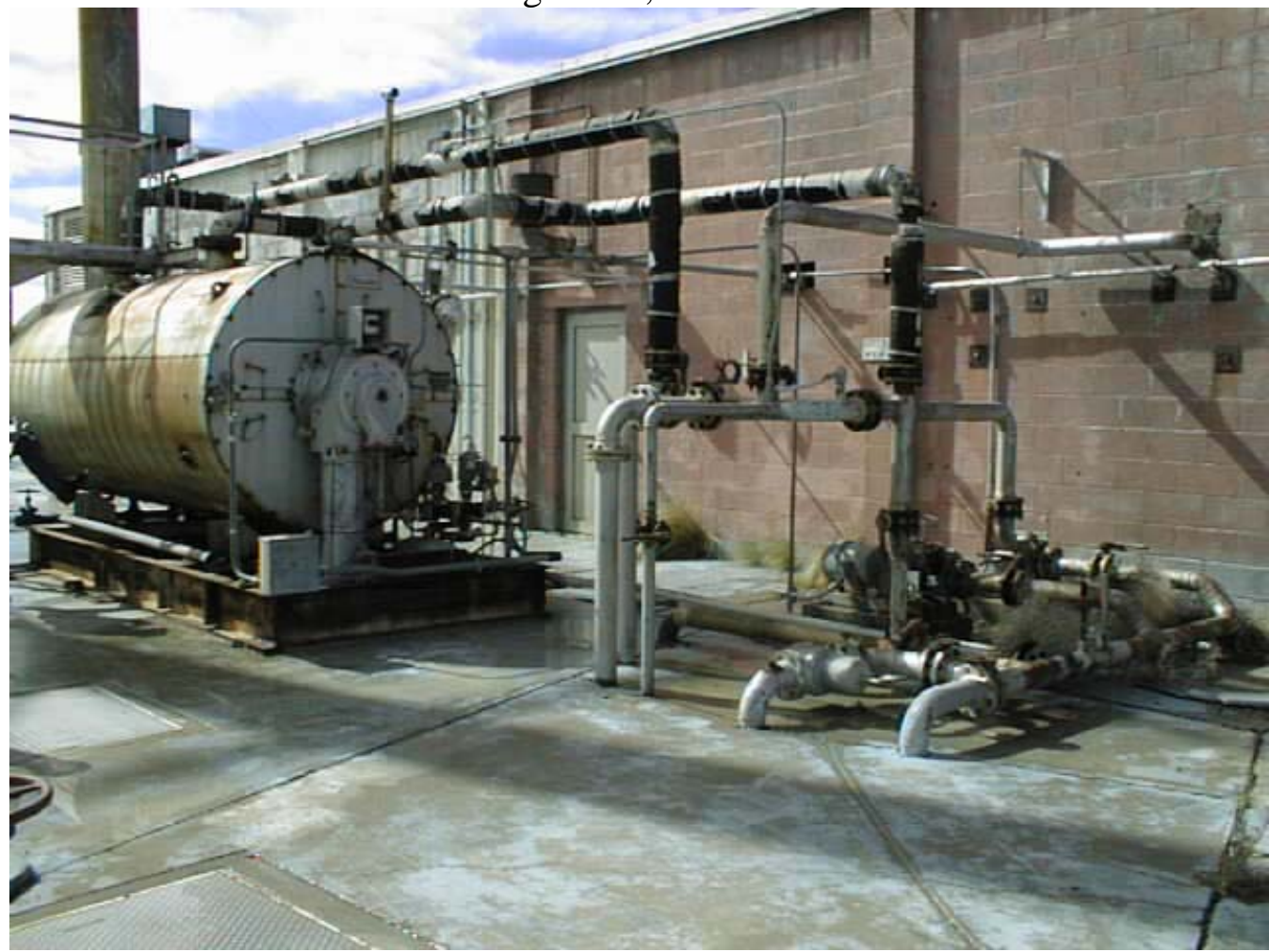

Photograph 20: CAS 25-12-01, Boiler Before Removal, Facing Southwest, 02/24/1998 


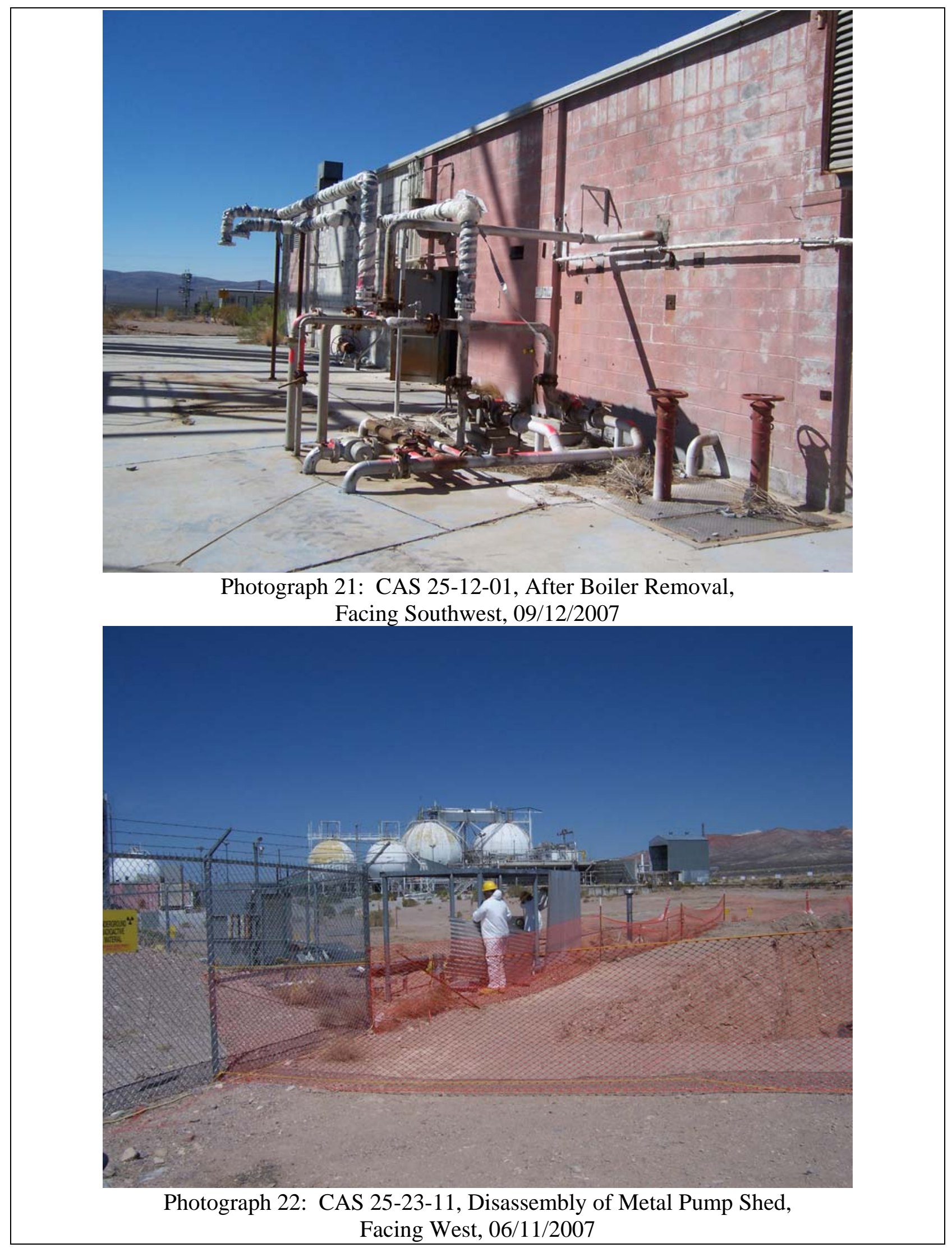




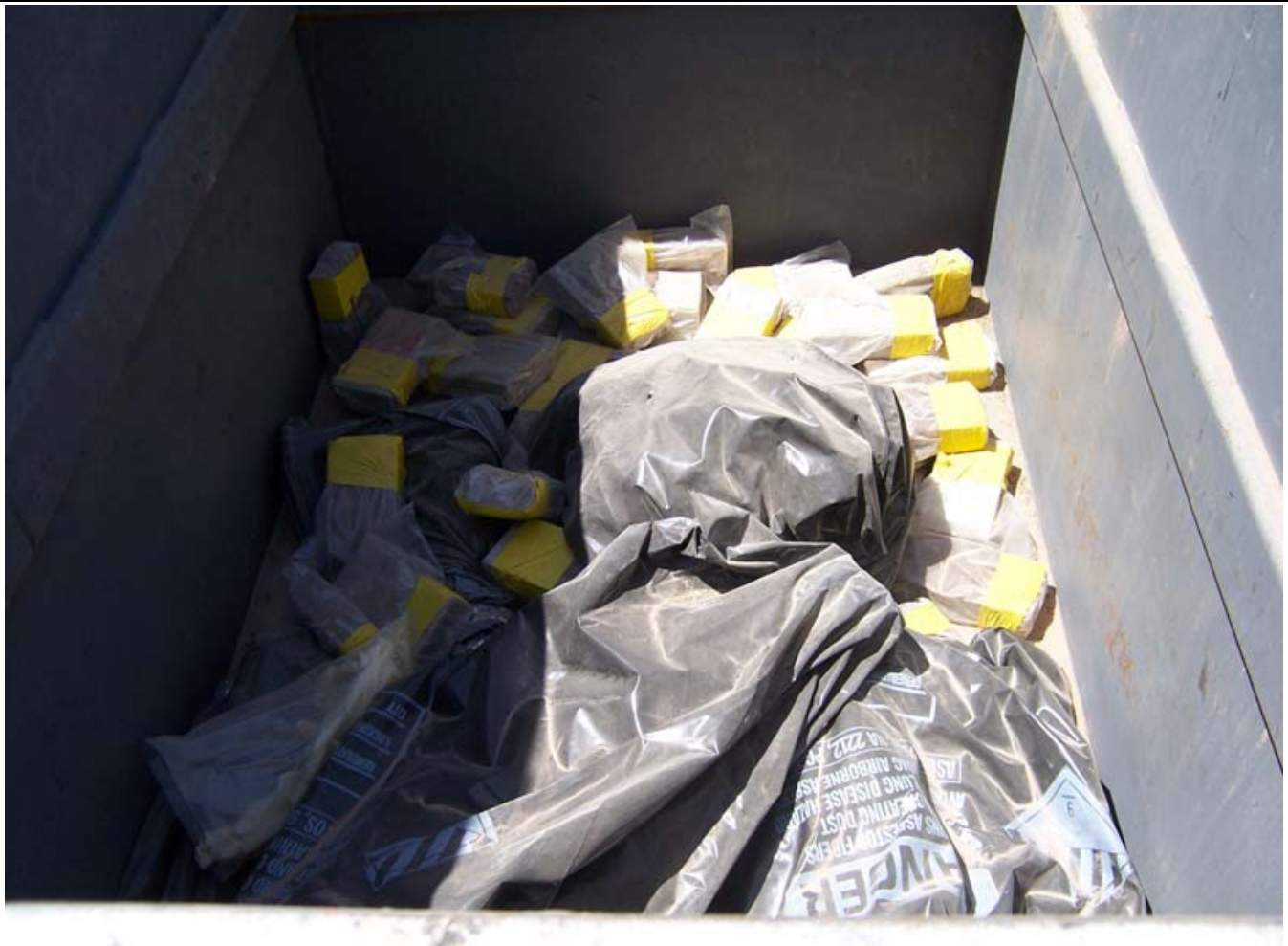

Photograph 23: CAS 25-23-11, Lead Bricks from Pump Vault in B-25 Box, 06/12/2007

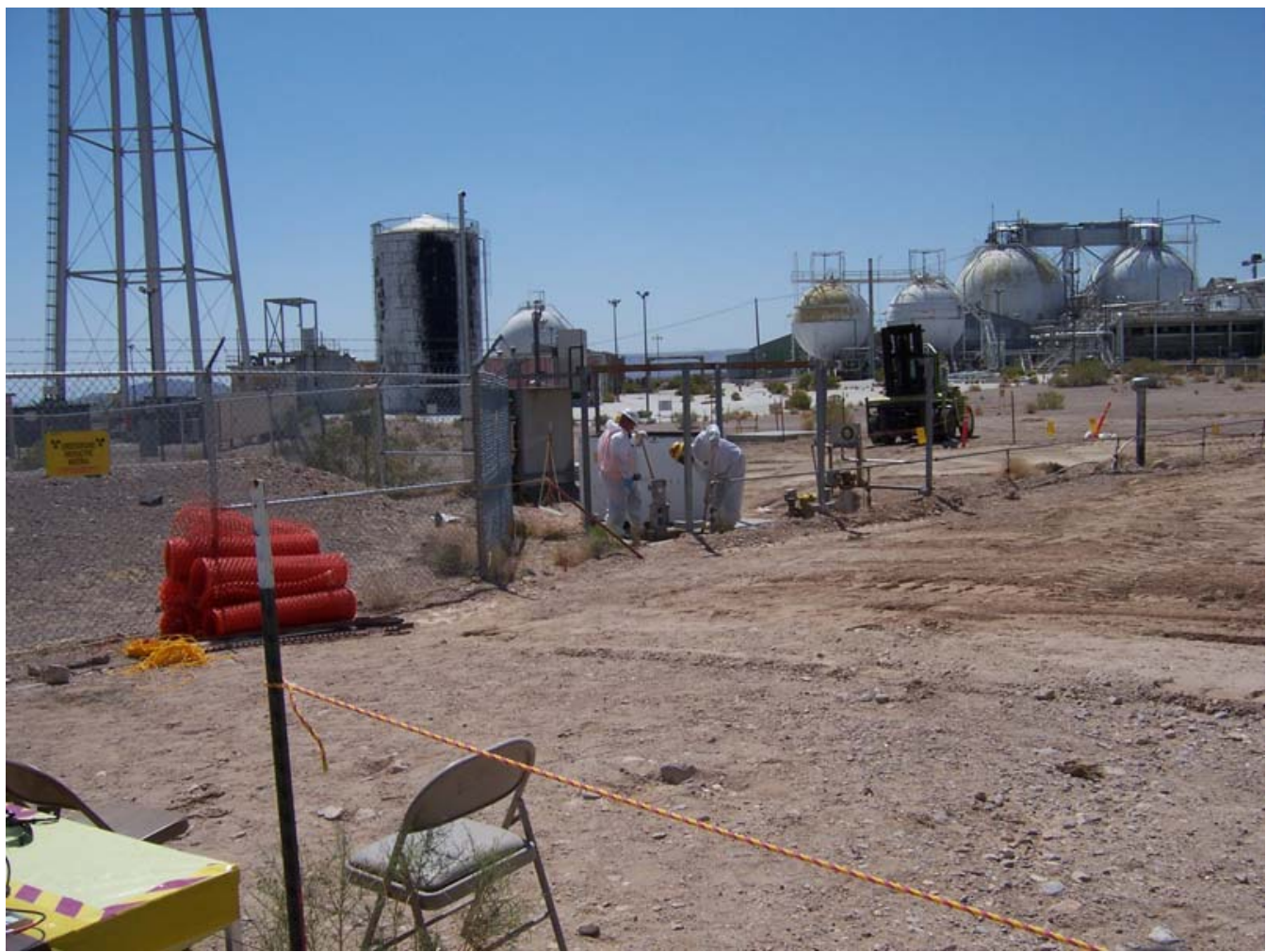

Photograph 24: CAS 25-23-11, Removal of Radiologically and Lead-Impacted Soil from Pump Vault, Facing West, 06/12/2007 


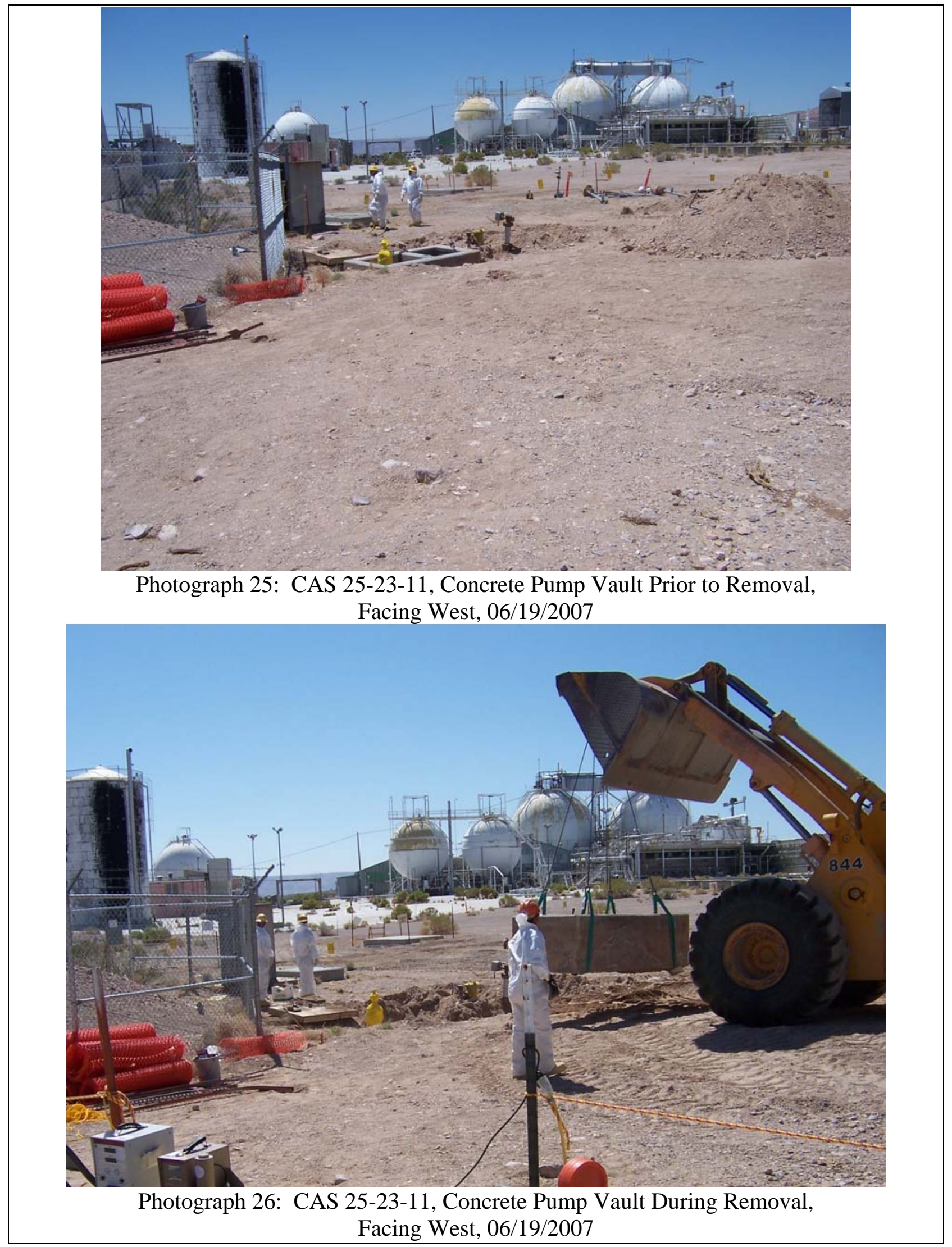




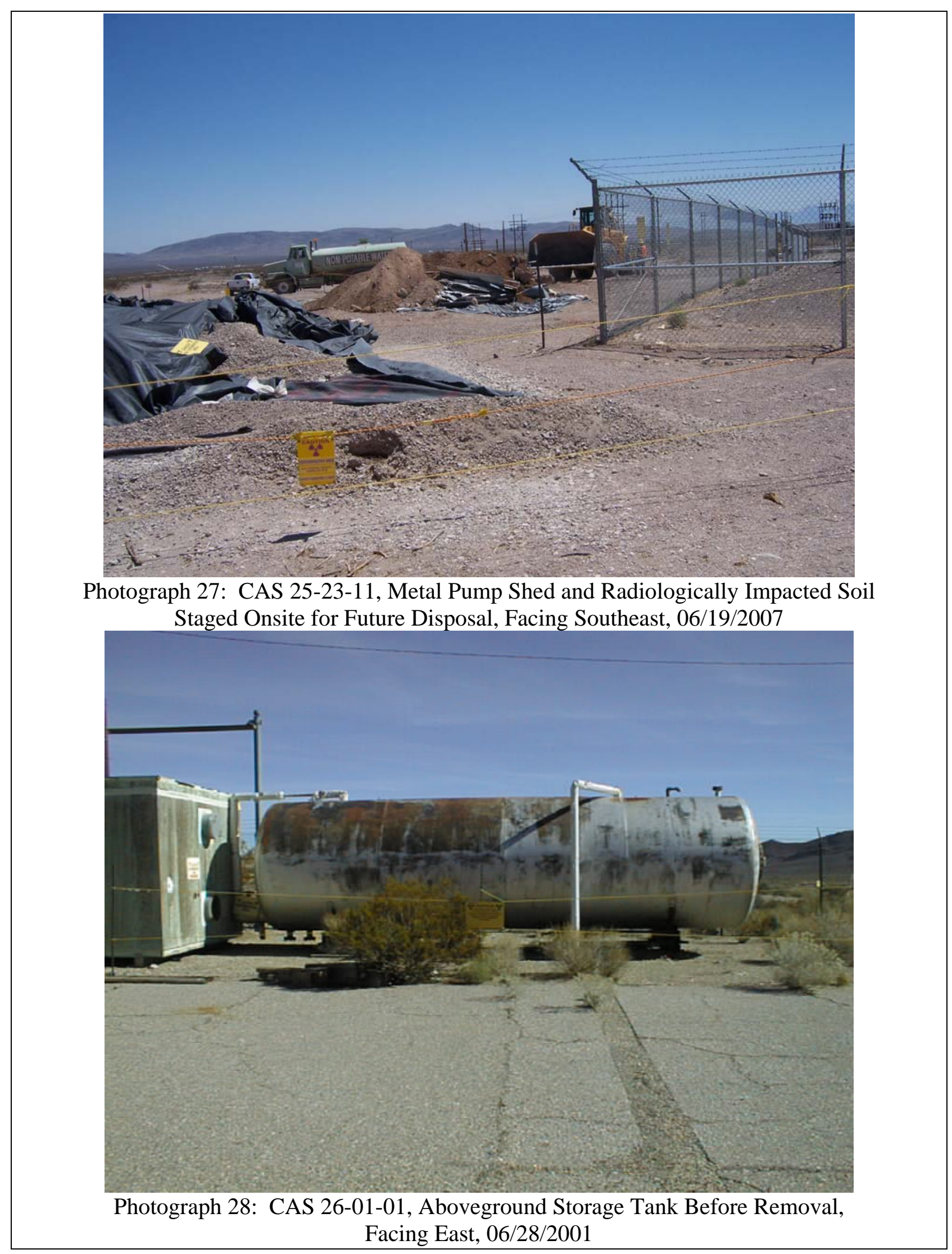




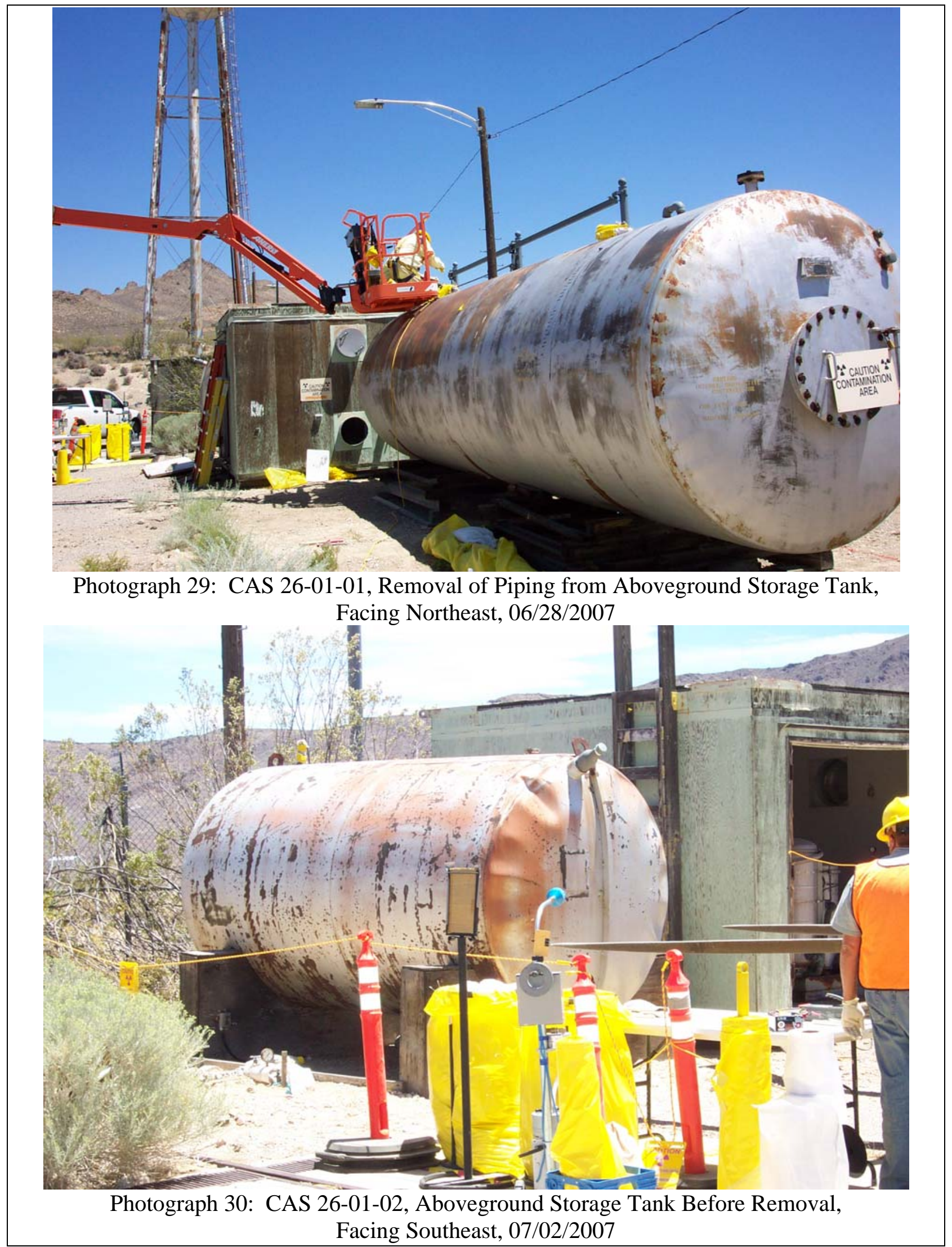




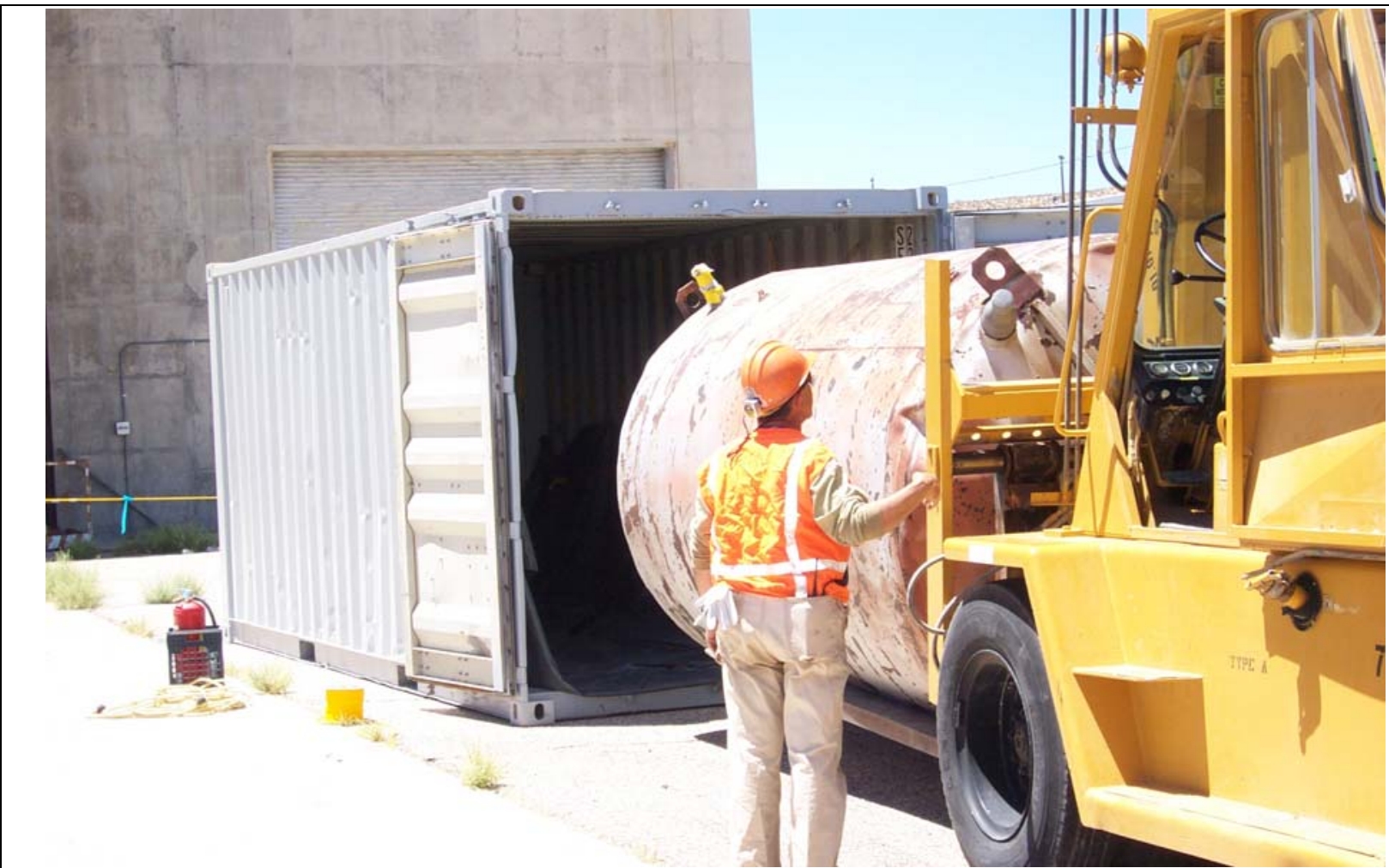

Photograph 31: CAS 26-01-02, Packaging Aboveground Storage Tank in Transportainer, Facing Northwest, 07/02/2007

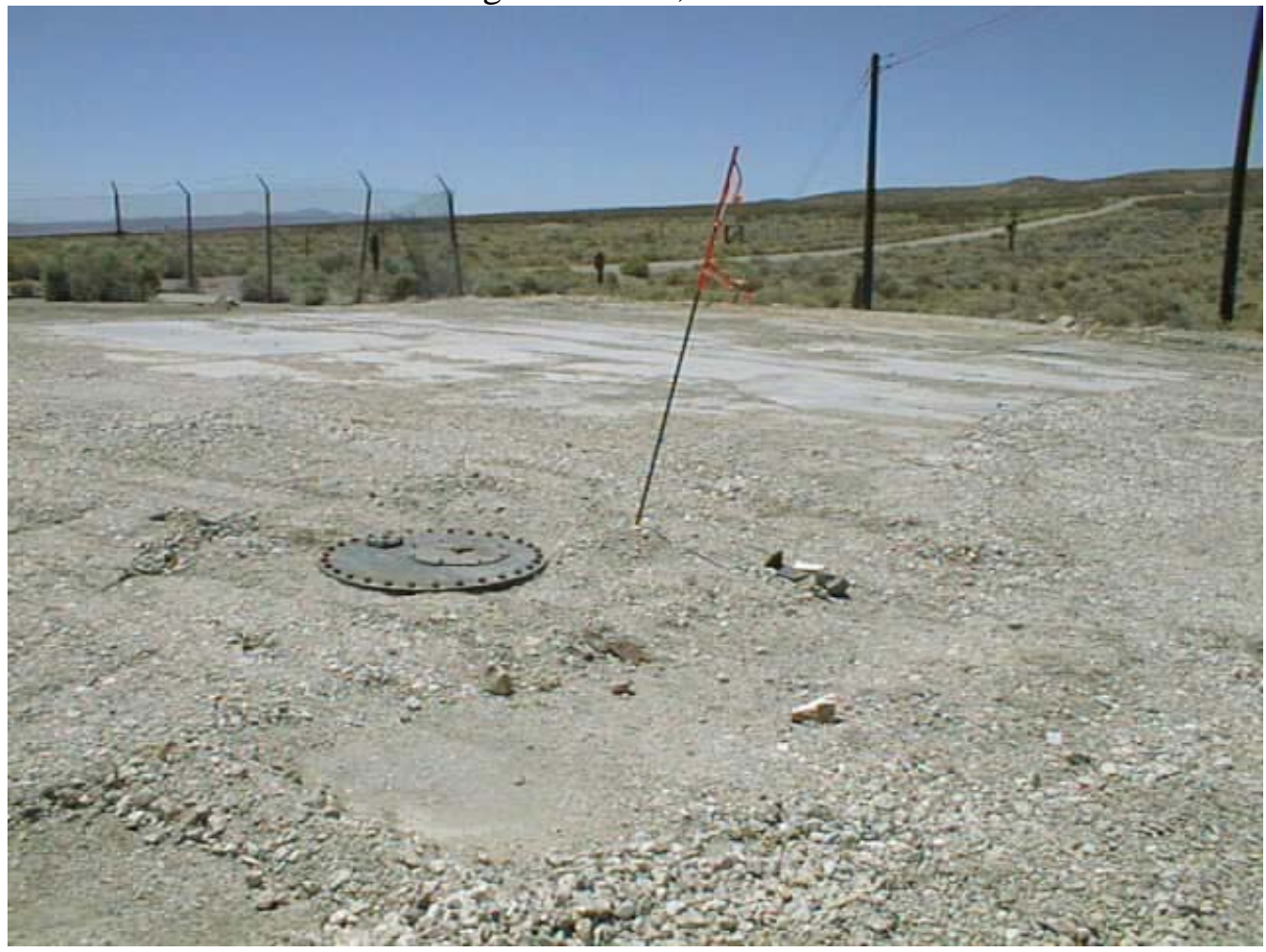

Photograph 32: CAS 26-02-01, Underground Storage Tank Before Closure Activities, Facing Northwest, 02/28/2001 


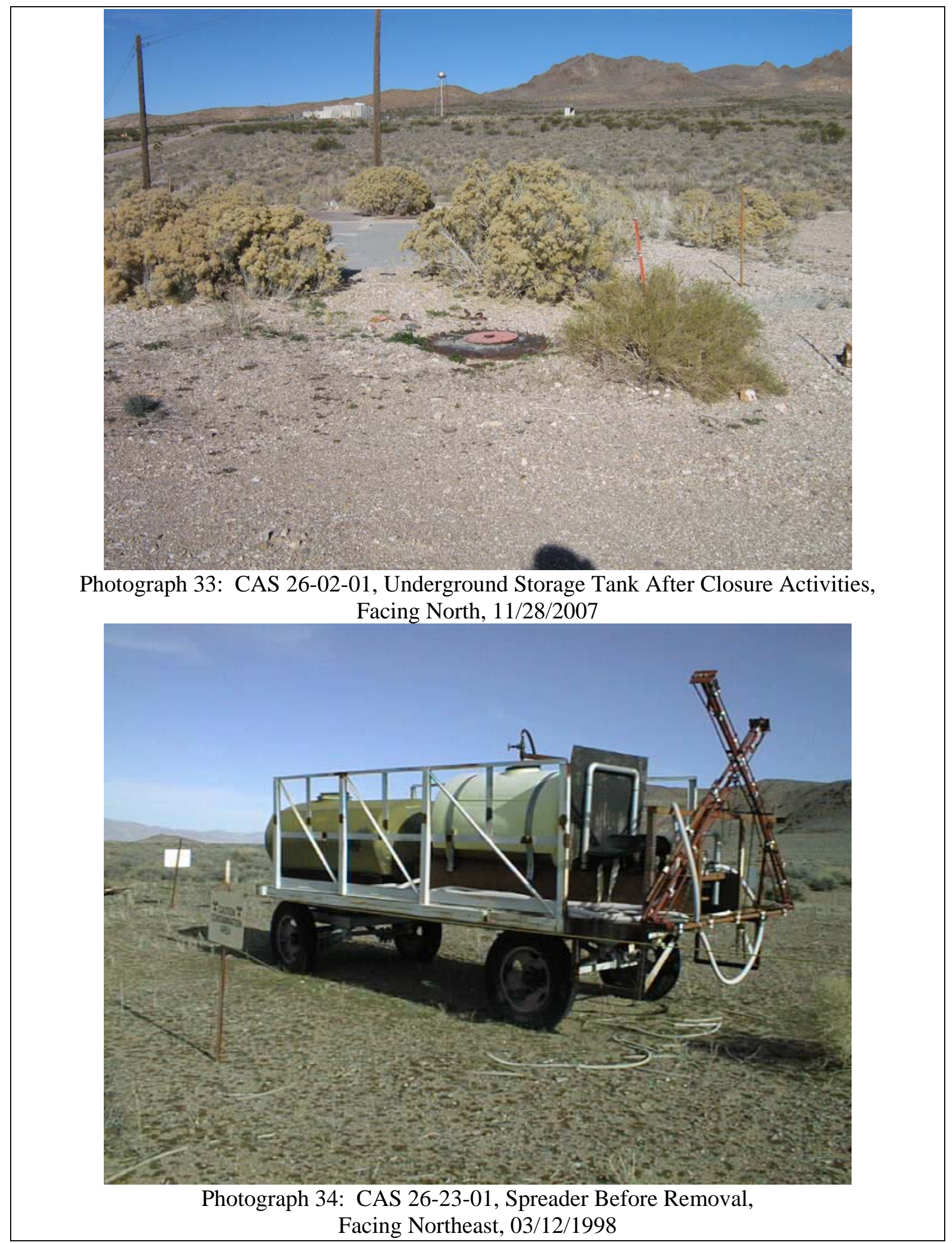




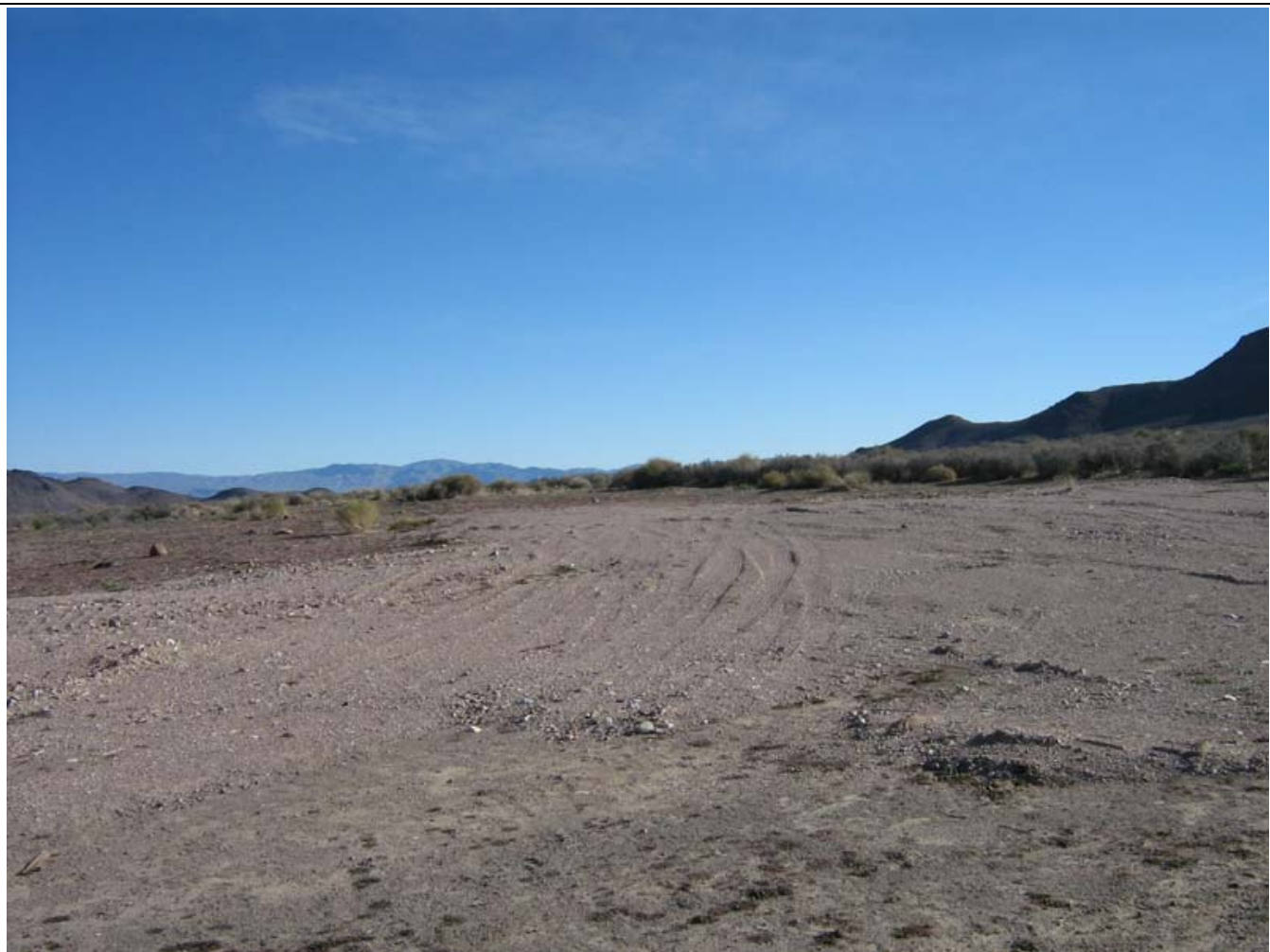

Photograph 35: CAS 26-23-01, After Spreader Removal, Facing Northeast, 11/28/2007

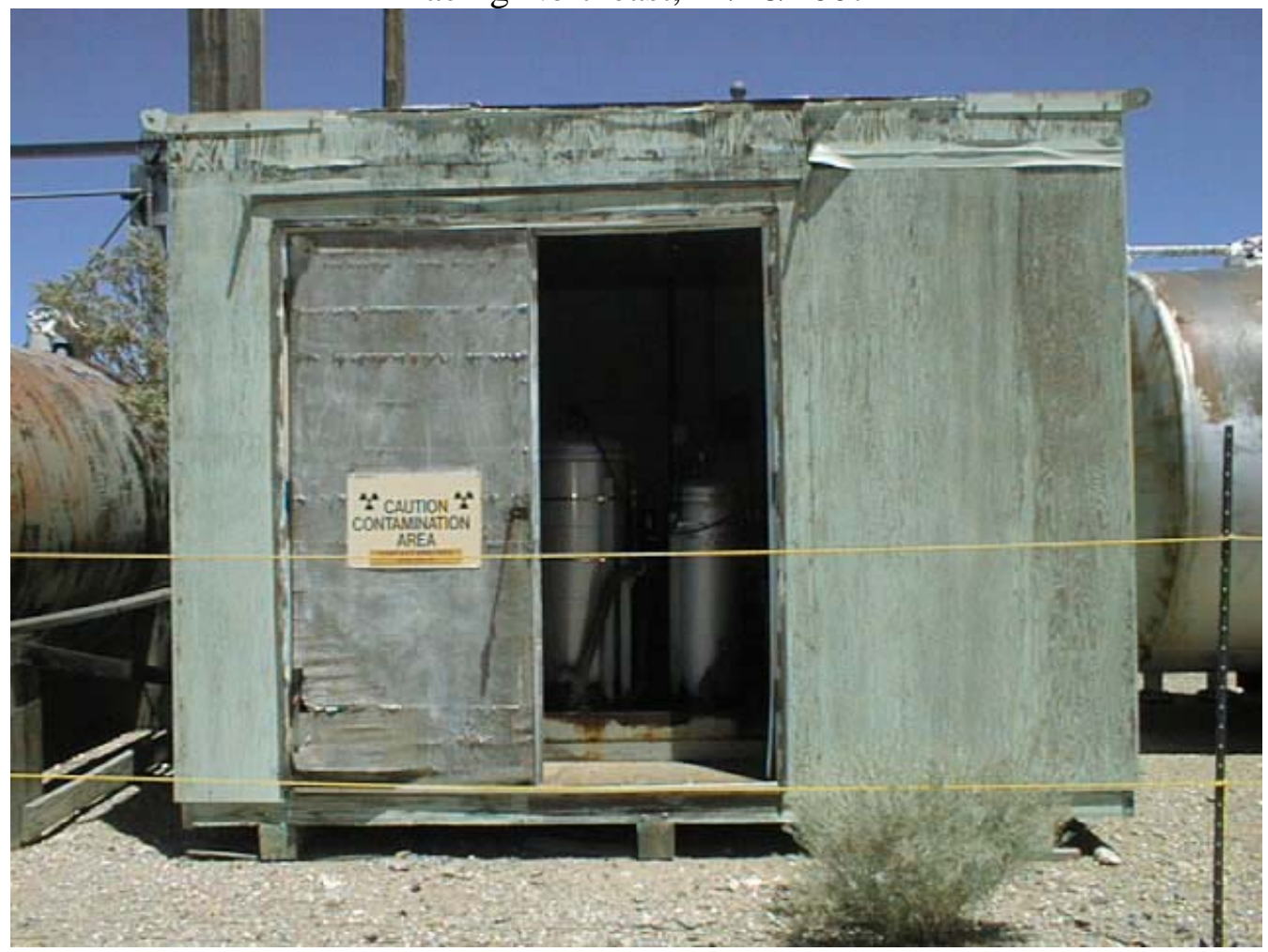

Photograph 36: CAS 26-99-01, Wooden Shed with Filter Tanks Before Removal, Facing East, 06/28/2001 


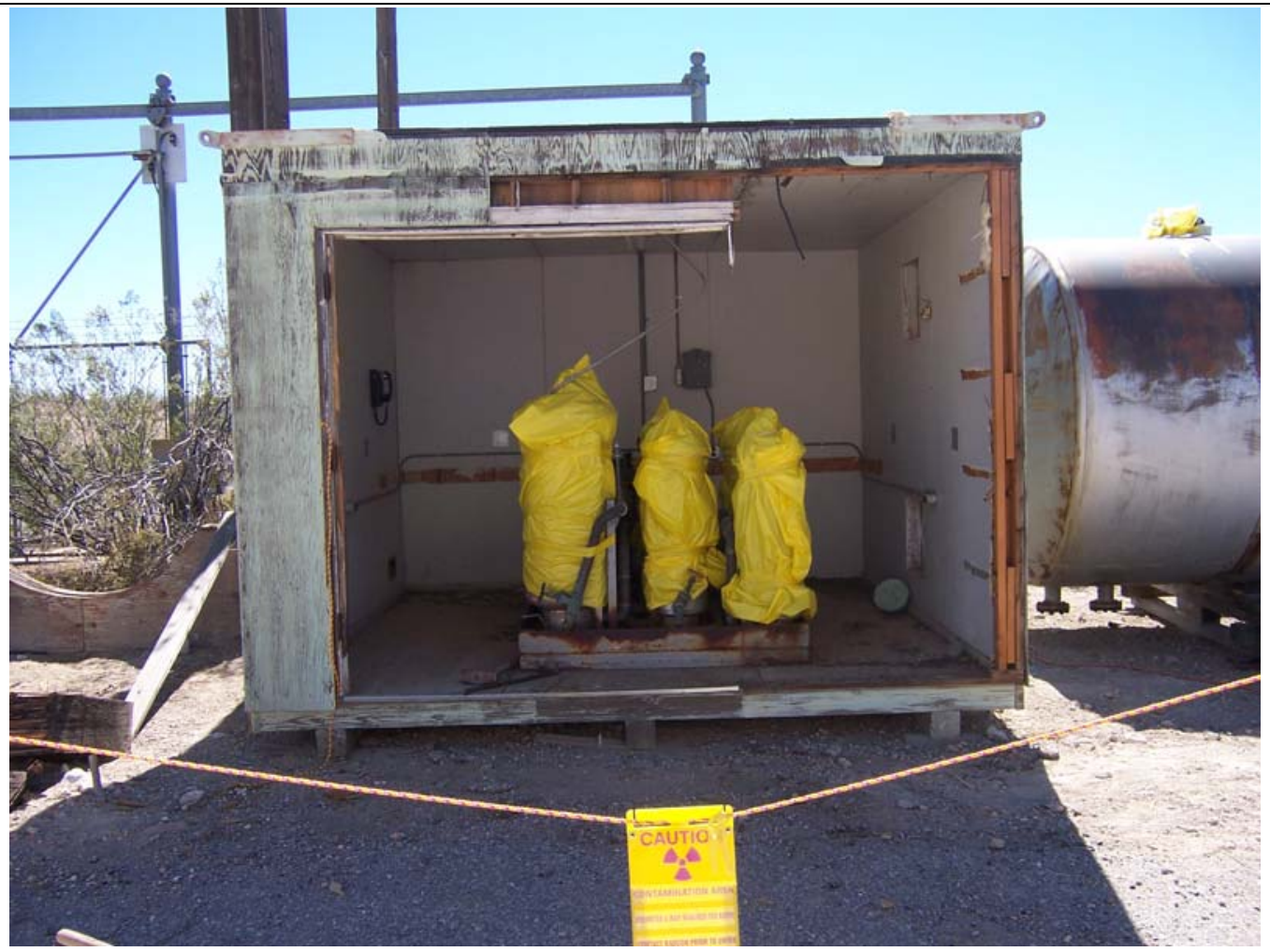

Photograph 37: CAS 26-99-01, Filter Tanks Before Removal, Facing East, 07/03/2007

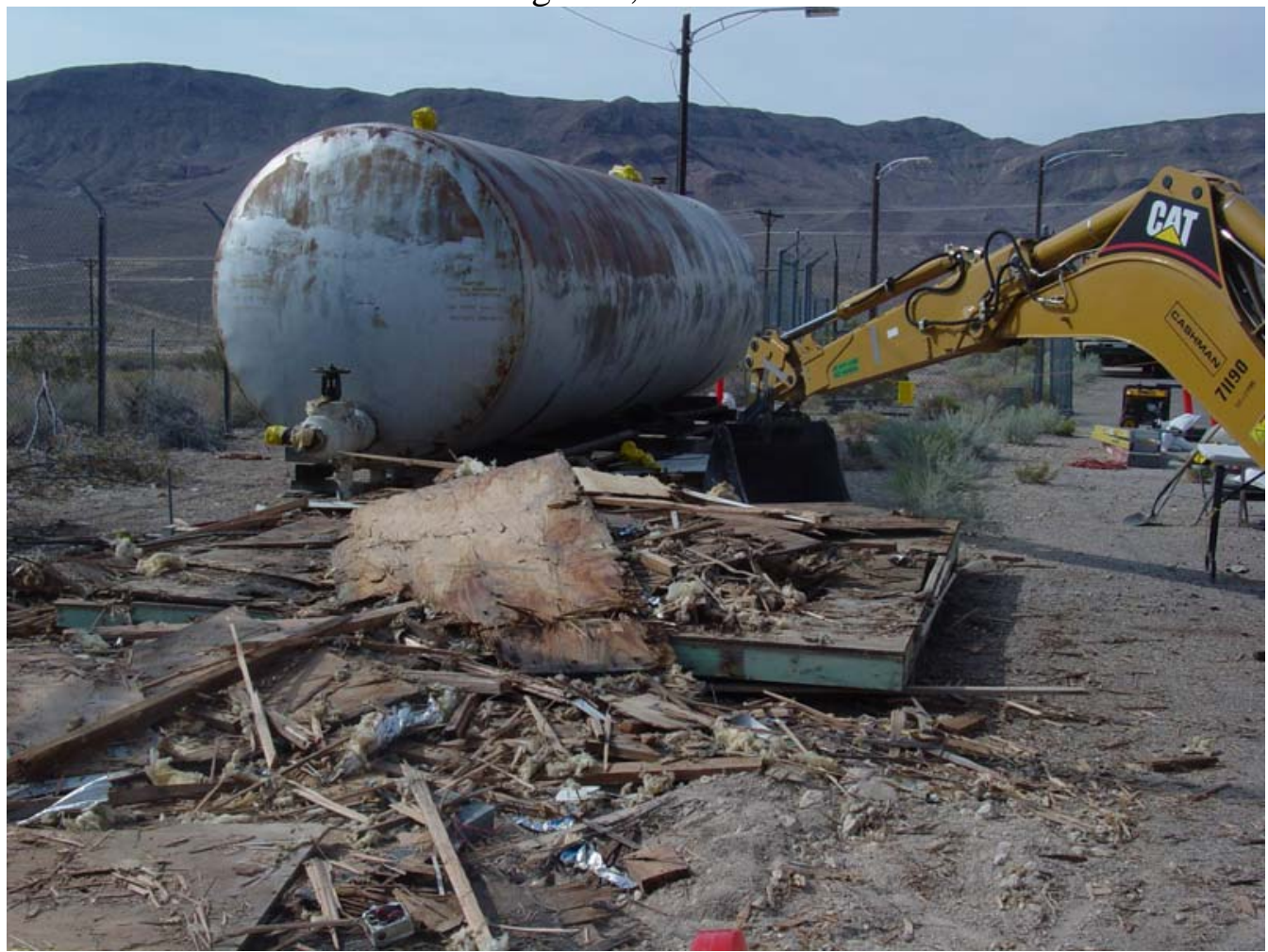

Photograph 38: CAS 26-99-01, Demolition of Wooden Shed, Facing Southwest, 07/10/2007 


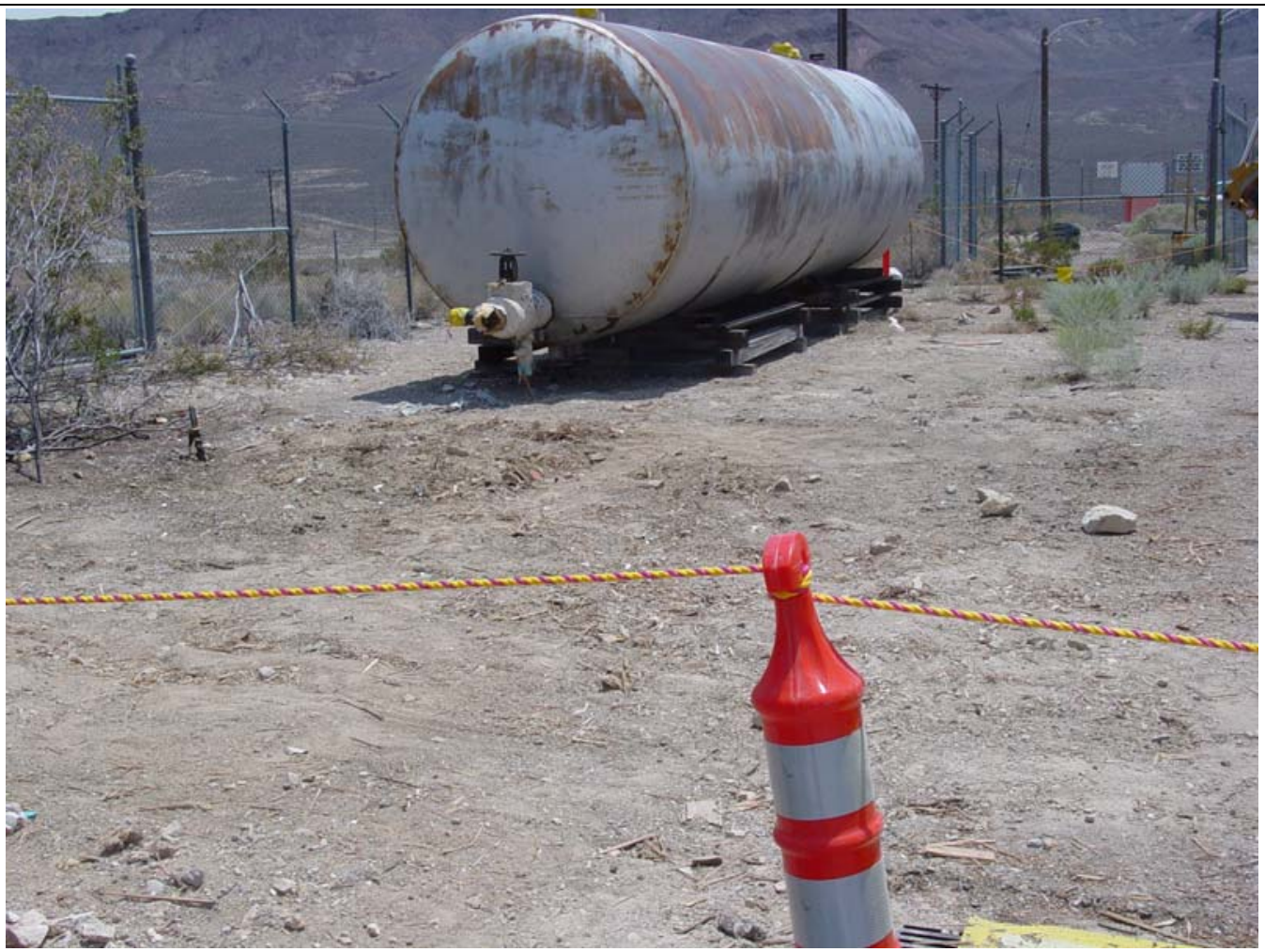

Photograph 39: CAS 26-99-01, After Closure Activities, Facing Southwest, 07/10/2007 
CAU 127 Closure Report

Section: Library Distribution List

Revision: 0

Date: February 2008

\section{LIBRARY DISTRIBUTION LIST}


CAU 127 Closure Report

Section: Library Distribution List

Revision: 0

Date: February 2008

THIS PAGE INTENTIONALLY LEFT BLANK 


\section{LIBRARY DISTRIBUTION LIST}

U.S. Department of Energy

National Nuclear Security Administration

Nevada Site Office

Technical Library

P.O. Box 98518, M/S 505

Las Vegas, NV 89193-8518

U.S. Department of Energy

Office of Scientific and Technical Information

P.O. Box 62

Oak Ridge, TN 37831-0062

Southern Nevada Public Reading Facility

c/o Nuclear Testing Archive

P.O. Box 98521, M/S 400

Las Vegas, NV 89193-8521

Manager, Northern Nevada FFACO

Public Reading Facility

c/o Nevada State Library \& Archives

Carson City, NV 89701-4285
1 (Uncontrolled, electronic copy)

1 (Uncontrolled, electronic copy)

2 (Uncontrolled, electronic copies)

1 (Uncontrolled, electronic copy) 
CAU 127 Closure Report

Section: Library Distribution List

Revision: 0

Date: February 2008

THIS PAGE INTENTIONALLY LEFT BLANK 